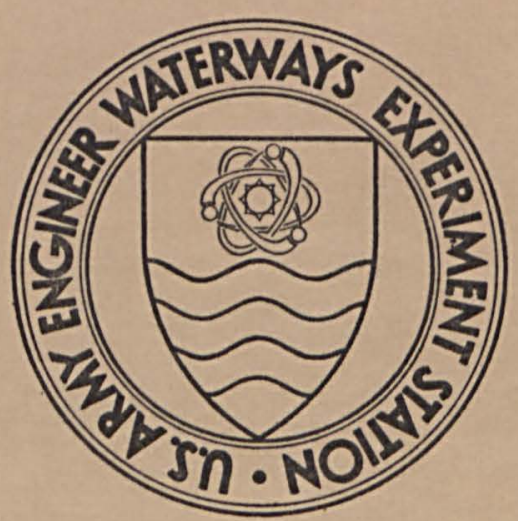

MISCELLANEOUS PAPER N-7I-3

\title{
DYNAMIC TESTS OF A MODEL FLEXIBLE-ARCH-TYPE PROTECTIVE SHELTER
} by

T. E. Kennedy
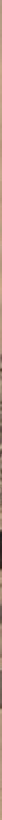

April 1971

Sponsored by Office, Chief of Engineers, U. S. Army

Conducted by U. S. Army Engineer Waterways Experiment Station, Vicksburg, Mississippi 
1988021

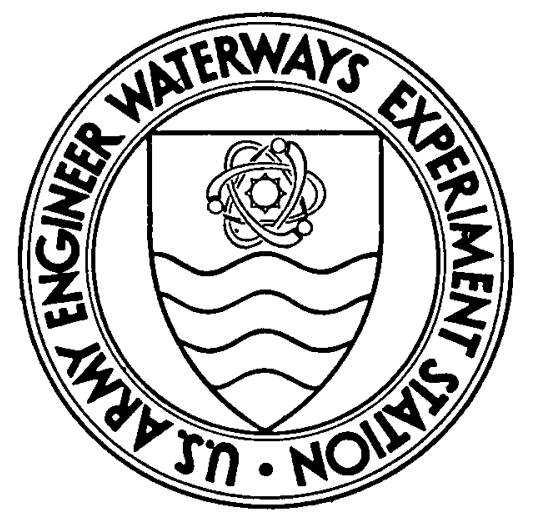

MISCELLANEOUS PAPER N-7I-3

\section{DYNAMIC TESTS OF A MODEL \\ FLEXIBLE-ARCH-TYPE PROTECTIVE SHELTER by}

T. E. Kennedy

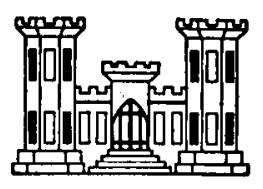

April 1971

Sponsored by Office, Chief of Engineers, U. S. Army Project 4A02260IA880-03

Conducted by U. S. Army Engineer Waterways Experiment Station, Vicksburg, Mississippi 


\section{$\mid A T$}

W34 m

no. $N-7 /-3$

Cop. 3

THE CONTENTS OF THIS REPORT ARE NOT TO BE USED FOR ADVERTISING, PUBIICATION, OR PROMOTIONAL PURPOSES. CITATION OF TRADE NAMES DOES NOT CONSTITUTE AN OFFICIAL ENDORSEMENT OR APPROVAL OF THE USE OF SUCH COMMERCIAL PRODUCTS. 
The general objective of this study was to determine the dynamic response of a buried model flexible-arch troop shelter to simulated nuclear blast overpressures. To accomplish this, a model structure was constructed using a geometric scaling ratio of 1 to 4.5. The structure was buried in dense, dry sand with the depth of cover over the crown equal to one-fourth of the arch diameter and tested in the Waterways Experiment Station Iarge Blast Load Generator. A series of five tests was conducted at overpressures ranging from 37 to 177 psi with the model being excavated and rebuilt after each test. Strain, acceleration, and deflection were measured at various points on the structure; measurements were also made of the pressure inside the structure, stress and acceleration in the free field, and overpressure at the soil surface.

Visible damage consisted of arch deformation, footing deflection, and fracture of the end truss bulkhead connector at the higher overpressures. All transient measurements in general were recorded successfully. The results of this study show that the model structure as designed can withstand almost twice the design overpressure of $100 \mathrm{psi}$ for large duration times (100 to $200 \mathrm{msec}$ ). Redesign of the truss connector can be accomplished as detailed in Appendix D so that no fracture occurs in this area. The instrumentation employed is described in detail in Appendix A. Raw and computed data are contained in Appendixes $B$ and $C$, respectively. 
This study was conducted at the U. S. Army Engineer Waterways Experiment Station (WES) for the Office, Chief of Engineers, Department of the Army, as a part of Task 03, "Military Engineering Applications of Nuclear Weapons Effects Research," Project 4A022601A880-03. It was accomplished during the period August 1965 through October 1967 under the general supervision of Mr. G. I. Arbuthnot, Jr., Chief of the Nuclear Weapons Effects Division, and under the direct supervision of Mr. W. J. Flathau, Chief, Protective Structures Branch (PSB). This report was prepared by Mr. T. E. Kennedy of PSB. Mr. G. L. Carre assisted during all phases of the fabrication and testing, and Mrs. C. M. Lloyd assisted with all data reduction.

COL John R. Oswalt, Jr., CE, COL Levi A. Brown, CE, and COL Emest D. Peixotto, $\mathrm{CE}$, were Directors of WES during the conduct of this study and preparation of this report. Technical Directors were Messrs. J. B. Tiffany and F. R. Brown. 
ABSTRACT -

PREFACE

NOTATION-

CONVERSION FACTORS, BRITISH TO METRIC UNITS OF MEASUREMENT

CHAPTER 1 INTRODUCTION

1.1 Background-1.

1.2 Objectives-.-

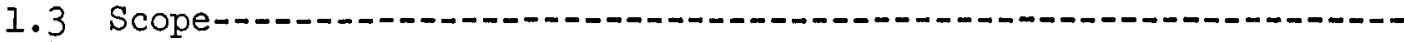

1.4 Scaling Considerations-a

CHAPTER 2 PROCEDURE- 19

2.1 Structure-1..... 19

2.1.1 General Description-_... 19

2.1.2 Arch Ribs-...- 20

2.1.3 Wooden Elements-....- 20

2.1.4 Bulkhead and Truss-_... 20

2.2 Test Configuration- 20

2.2.1 Test Device-n.... 20

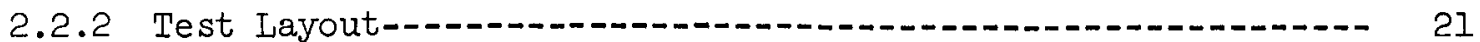

2.2.3 Specimen Construction-

2.3 Soil Properties-- 22

CHAPTER 3 RESULTS- 34

3.1 Loading Input-1 34

3.1.1 Surface Airblast-_. 34

3.1.2 Free Field-_.

3.2 Visual Damage Survey-... 35

3.2.1 General Gross Motion and Damage-..... 35

3.2.2 Component Damage-1... 36

CHAPTER 4 DISCUSSION OF RESULTS- 51

4.I Structural Loading-_... 51

4.1.1 Free Field-_... 51

4.1.2 Radial Interface Loading-_. 52

4.2 Structure Motion-1.. 53

4.3 Structural Response-_.

4.4 Interior Environment 56

CHAPTER 5 CONCLUSIONS AND RECOMMENDATIONS- 79

5.1 Conclusions

5.2 Recommendations-_. 79

APPENDIX A INSTRUMENTATION DETAILS AND TABULATED RESULTS-......... 81

APPENDIX B RAW DATA 101 
APPENDIX D BULKHEAD-TRUSS CONNECTOR REDESIGN-_. 157

REFERENCES-1-10-1

TABIES

1.1 Model and Prototype Resistance and Response Parameters-_....... 16

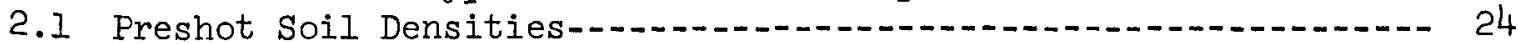

3.1 Surface Airblast Overpressure Parameters..................... 38

4.1 Ratio of Radial Load to Peak Transient Radial Load-..........-. 57

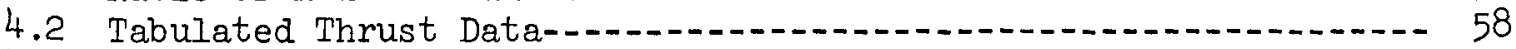

4.3 Tabulated Moment Data-........................................ 59

A.1 Oscillograph System Frequency Response-......................... 85

A.2 Airblast Results-_.-_... 86

A.3 Soil Stress Results-_._-_._._-_. 87

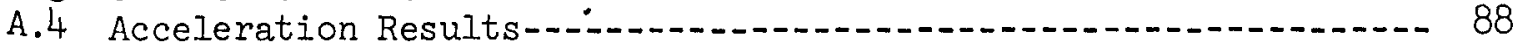

A.5 Deflection Results-.............. 89

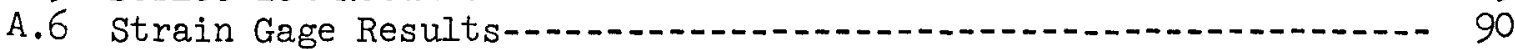

FIGURES

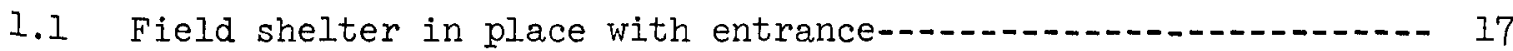

1.2 Exploded view of the field shelter and entrance complex-...-.- 18

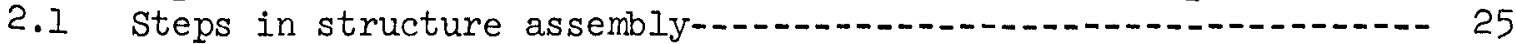

2.2 Test geometry and location in the LBLG -..................... 27

2.3 Plate-bearing test resuIts at footing level-...............- 28

2.4 Grain-size distribution curve for the test sand-..........-.- 29

2.5 Relation between angle of internal friction and density for the test sand-...... 30

2.6 One-dimensional static confined compression test data for the

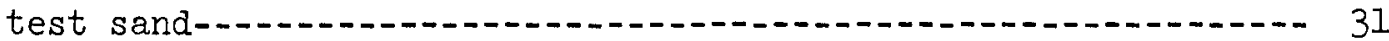

2.7 Stress-strain curves for the test sand; density 99.7 pcf...... 32

2.8 Velocity data for the test sand; density 99.7 pef-..........- 33

3.1 Composite surface airblast overpressure curves-............. 39

3.2 Initial impulse data-................ 40

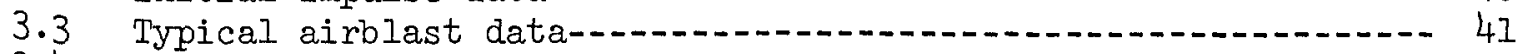

3.4 Depression in the sand surface caused by the gross motion of the structure during Shot 4-............. 42

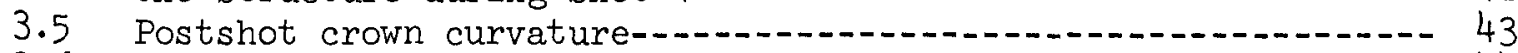

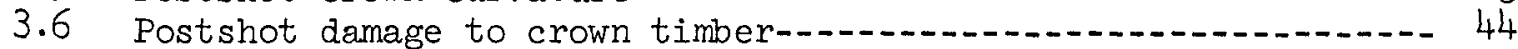

3.7 Postshot view of the damaged footings showing the punching

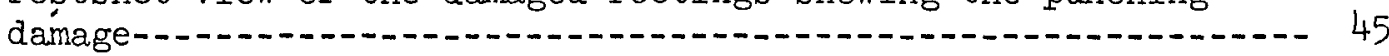

3.8 Section views of the damage shown in Figure 3.7 to the footings at the section shown (Section AA) -

3.9 Sand spall of the interior floor surface during Shot 4....... 47

3.10 Dislocation of Gage 51VA caused by spalling of the interior

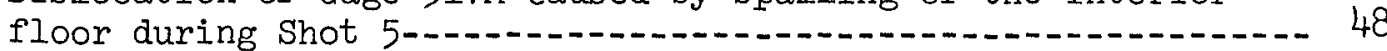

3.11 Shear damage to connector bolts, main photographs showing the post-pilot-test damage-...................................... 49

3.12 Damage to the redesigned bulkhead beam-truss connector-.......- 50

4.1 Soil stress wave velocity 
Permanent deformation of Rib 6 after Shots 3, 4, and 5--.-

Level survey, postshot crown deflection with respect to

4.7 the footings-.....

$4.8-4.10$

Level survey data for footings

Footing motion of the north footing center during Shots

4.11 3 through 5

4.12

Peak acceleration of footing-

4.13

4.14

4.15

4.16

4.17

4.18

4.19

Peak velocity of footing

Typical motion data at footing center; Shot 5, Gage 53VA-Rib idealization-............

Idealized thrust and moment histories-.......

Typical elastic and plastic thrust and moment data-.....-

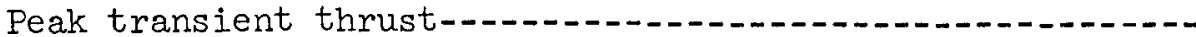

Peak interior pressure versus footing deflection-......-. Acceleration- and velocity-time histories of the interior floor, Shot 4 (Gage 5IVA)

4.20

A.1

A. 2

A. 3

A. 4

A. 5

A. 6

Peak motions of the interior floor (Gage 5lVA) General view of the recording and conditioning equipment-Instrumentation diagrams for shots 1 to 5 Transducers used during the test series-...Footing and crown deflection rig, Preshot 1....... Fully instrumented structure prior to placing timber lagging, Preshot 3... Numbering convention-..... A. 7

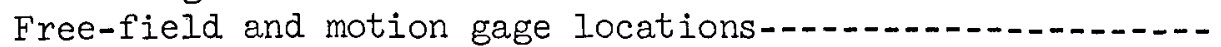
Shot 1 , oscillograph record from Recorders 1 through 5--B. $6-\mathrm{B} .10$ B.11-B.16 B. 17-B.22 B. $23-B .26$ $\mathrm{C} .1-\mathrm{C} .5$ Shot 2, oscillograph record from Recorders 1 through 5-... Shot 3, oscillograph record from Recorders 1 through 6..Shot 4, oscillograph record from Recorders 1 through 6-.-Shot 5, oscillograph record from Recorders 1 through 4...Velocity data, Shots 1 through 5 Displacement data, Shots 1 through 5 Thrust data, Shot 1. Moment data, Shot 1._._...... 141 Thrust data, Shot 2-1... 142 Moment data, Shot 2-1.... 143 Thrust data, Shot 3-1. Moment data, Shot 3...... Thrust data, Shot 4-1.. Moment data, Shot truss connection 
D.3 Detail of the modifications made in the prototype truss

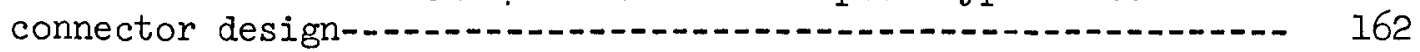

D.4 Detail of the modifications made in the prototype column

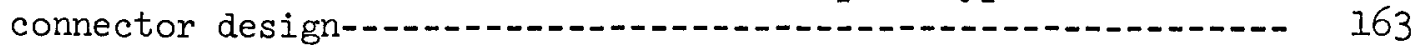

D.5 Plate detail for prototype column connector modification-.-.-- 164 


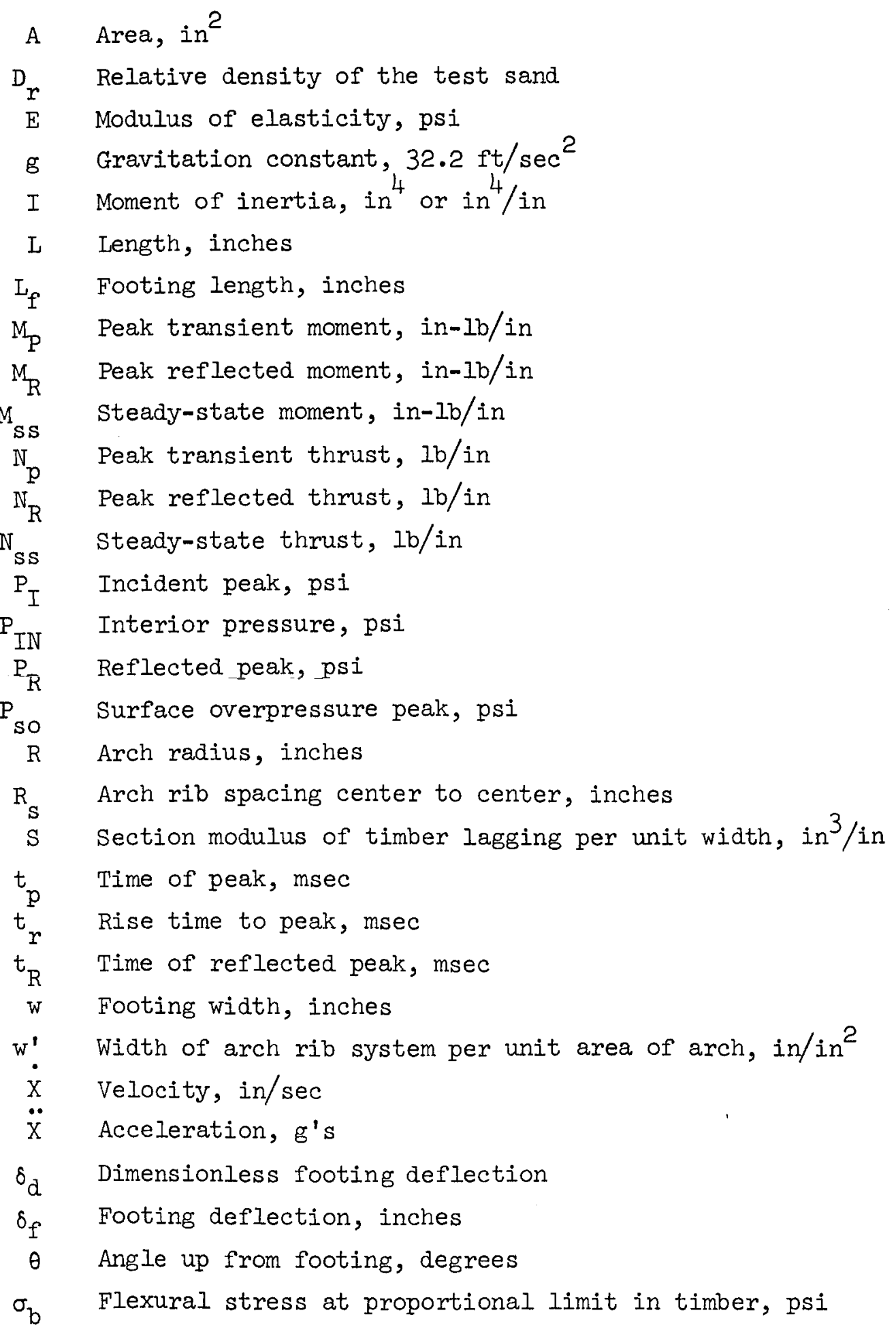


$\sigma_{\text {UIT }} \quad$ Ultimate plate bearing stress, psi

$\sigma_{\mathrm{y}} \quad$ Yield stress, psi 
British units of measurement used in this report can be converted to metric units as follows.

\begin{tabular}{lcl}
\hline \multicolumn{1}{c}{ Multiply } & By & \multicolumn{1}{c}{ To Obtain } \\
\hline inches & 25.4 & millimeters \\
feet & 0.3048 & meters \\
square inches & 645.16 & square millimeters \\
cubic yards & 0.7645549 & cubic meters \\
megatons & 0.9071847 & teragrams \\
kips & 4.448222 & kilonewtons \\
pounds per inch & 175.1268 & newtons per meter \\
pounds per foot & 14.59390 & newtons per meter \\
pounds per square inch & 6.894757 & kilonewtons per square meter \\
kips per square inch & 6.894757 & meganewtons per square meter \\
kips per square foot & 4.788026 & kilonewtons per square meter \\
pounds per cubic foot & 16.01846 & kilograms per cubic meter \\
microinches per inch & 0.001 & microns per millimeter \\
inch-pounds per inch & 4.448222 & newton-meters per meter
\end{tabular}




\section{I.I BACKGROUND}

The development of strategic and tactical nuclear weapons and efficient delivery systems has exposed the field Army to all the hazards of nuclear warfare. No longer is the nuclear weapon a rarity in arsenals of the major powers of the world, but it now has a wide range of yield and is a relatively inexpensive form of explosive. Currently, the envisioned military usage of these weapons ranges from barrier formation caused by cratering action to destruction of bridges and other individual structures to megalopolis annihilation.

If a modern military establishment is to withstand an attack by such weapons, the various units (functions) of such an establishment must survive the effects of these weapons. This means that each military unit should have some degree of protection, the level of protection varying with the value of the individual unit. Reduced vulnerability of a military unit can be achieved either by hardening the unit or-by duplicating it; obviously, there is a trade off between the two techniques. As the importance of the functional unit increases, generally, the cost per unit also increases, so that the cost of duplication becomes greater and the value of economical hardening increases. The requirements of providing a high degree of hardening for the individual soldier are minimal, whereas an important command center would require a high degree of hardening.

In order to provide a field-shelter concept to furnish a relatively hard cover for field use, a contract was awarded to N. M. Newmark (INMV), Consulting Engineering Services, Urbana, Illinois, by the U. S. Army Engineer Waterways Experiment Station (WES), Vicksburg, Mississippi, in December 1957 to develop an economical 51-man protective troop shelter for field use. The concept was to provide protection against the effects of a megaton $^{1}$ nuclear weapon at a 100-psi air overpressure level. In addition, the

A table of factors for converting British units of measurement to metric units is presented on page 12. 
shelter had to be of such design that construction could be completed within one week by a 5l-man platoon. Results of this work were published in Reference 1. Based on considerations of economy, hardness level, radiation protection, and ease of construction, an underground flexible structure to be placed in soil above the ground water table was selected.

The prototype shelter is 16 by 48 feet in plan and is to be supplied in 12-foot-long, air-droppable modular kits. The shelter and entrance complexes are shown in Figures 1.1 and 1.2. The shelter consists of 8-footradius steel arch ribs, which support timber blocks. These ribs are made of rolled or forged quarter-circle, split, structural tees with the stem of the tee turned out. The rib sections are welded to bearing plates which are bolted to a crown or ridge timber and to a composite heavy timber and steel channel footing at the base. The timber blocks forming the roof are supported by the flanges of the tees. The end rib is made of an angle section that frames and supports the top of the end bulkhead. The forces at the base of the bulkhead are resisted by a welded steel truss reacting against the footings of the structure. Vertical wide-flange beams extend from the truss to the arch end rib. The bulkhead wall is formed by placing timber blocks horizontally between the webs of the vertical beams; the blocks are held in place by angle sections welded to the webs. Ingress and egress are provided by means of separate entrance kits which can be used at either or both ends. The entrance complex also provides space for ventilation equipment, a power generator, and fuel storage.

The mechanism of load transfer to a buried structure, sometimes referred to as soil arching, is not fully understood. Because of this uncertainty, it is necessary to overdesign such structures--a procedure which usually produces an uneconomical stmucture that may not necessarily be safe. A full-scale nuclear field test is the ideal method of design verification; however, because of the moratorium on atmospheric nuclear testing, it was decided to conduct a series of design verification tests on a model of the shelter in the WES Iarge Blast Load Generator (IBIG). Consequently, the contract with IMM was extended to encompass the design of a scale model of the field shelter and to propose a test program to verify structural adequacy of the prototype (Reference 2). 


\subsection{OBJECTIVES}

The basic objective of the study reported herein was to determine, in a general manner, the response characteristics of a model of the flexiblearch troop shelter when subjected to the design overpressure of 100 psi and to determine the ultimate load-carrying capability of the structure. Specific objectives were (1) to determine areas of weakness in the design and to modify the design to overcome these weaknesses and (2) to determine footing response and extrados loading.

\subsection{SCOPE}

A model structure was constructed, and a series of tests was conducted using overpressures below, up to, and exceeding the design overpressure. Including the pilot test reported in Reference 3 , six tests were conducted at overpressures ranging from 37 to $177 \mathrm{psi}$. All tests were conducted dynamically in dense dry sand with the crown of the structure buried onefourth the diameter of the arch below the soil surface. Measurements were made of surface air overpressure, structural strain, accelerations, deflection, and free-field response in the vicinity of the structure.

\subsection{SCALING CONSIDERATIONS}

The scaling of the model is outlined in detail in Reference 2 and will be briefly discussed in the following. The model was constructed from the same materials as the prototype, and the linear dimensions were changed by a factor of $1 / 4.5$. Using this scaling, the soil stresses at these shallow depths due to the applied loads are assumed the same in both the model and prototype; consequently, the applied loads are assumed to be the same. The scaled differences in dead-load stresses were ignored since these stresses are small compared to the applied dynamic loads. Whenever minor deviations from geometrical scaling were required, the areas or moments of inertia were scaled, e.g., for axial or shear-loaded members the areas were scaled as $(1 / 4.5)^{2}$, and for members loaded in flexure the section modulus was scaled by $(1 / 4.5)^{3}$. Some values of response parameters are given in Table 1.1 for the model and prototype. 
TABLE 1.1 MODEL AND PROTOTYPE RESISTANCE AND RESPONSE PARAMETERS

Symbols used are defined in the Notation which precedes the text.

\begin{tabular}{|c|c|c|c|}
\hline Response Mode & Relation & $\begin{array}{l}\text { Prototype } \\
\text { Value }\end{array}$ & $\begin{array}{l}\text { Model } \\
\text { Value }\end{array}$ \\
\hline
\end{tabular}

Rib compression

mode resistance

$\frac{\sigma_{\mathrm{y}} \mathrm{A}}{\mathrm{RR}}$

26 psi

mode resistance

Timber lagging

flexural resistance

Compression mode

period (no soil)

Flexural mode

period (no soil) $\frac{3 E I}{R^{3} R_{S}}$

$34 \mathrm{psi}$

$\frac{8 \sigma_{b} S}{L^{2}}$

$124 \mathrm{psi}$

152 psi

260 psi

$266 \mathrm{psi}$

$2 \pi(R)\left(\frac{W^{\prime}}{E A g}\right)^{1 / 2}$

$2.9 \mathrm{msec}$

$0.677 \mathrm{msec}$

$1.28 \pi\left(\frac{W^{\prime}}{E I g}\right)^{1 / 2}$

$139 \mathrm{msec}$

$29.8 \mathrm{msec}$ 

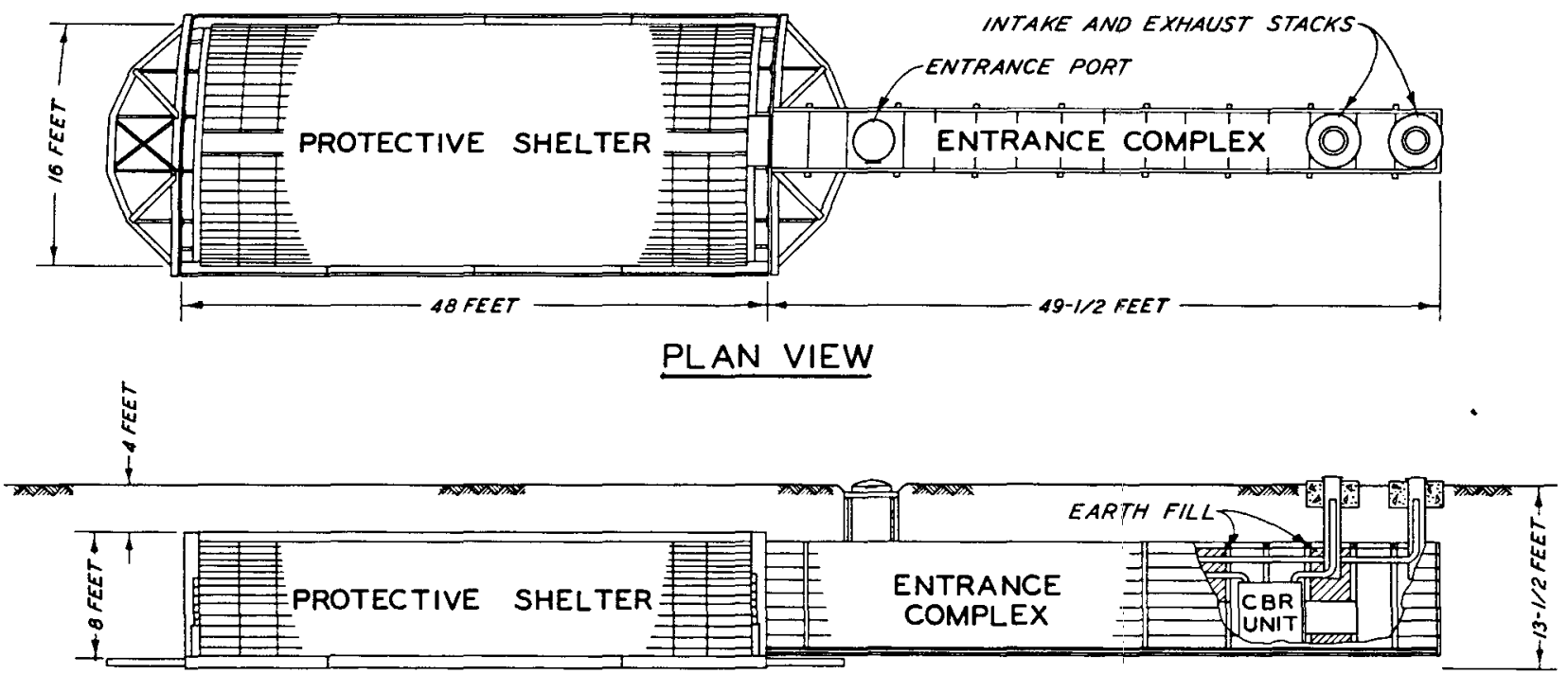

\section{SIDE VIEW}

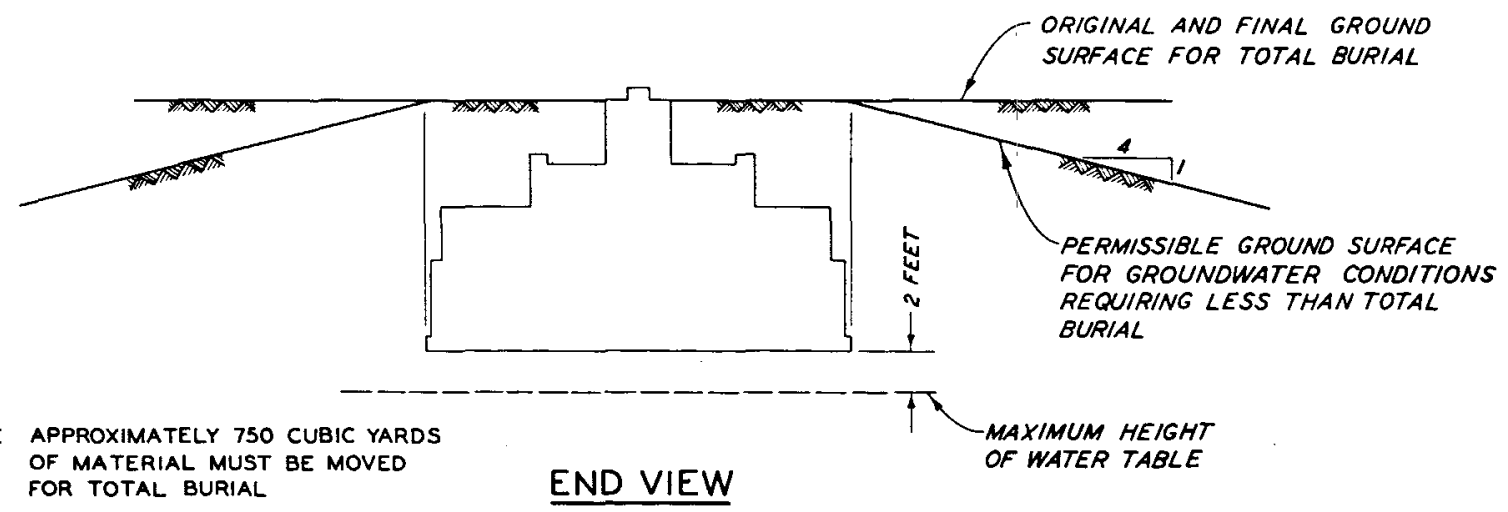

Figure 1.I Field shelter in place with entrance. 


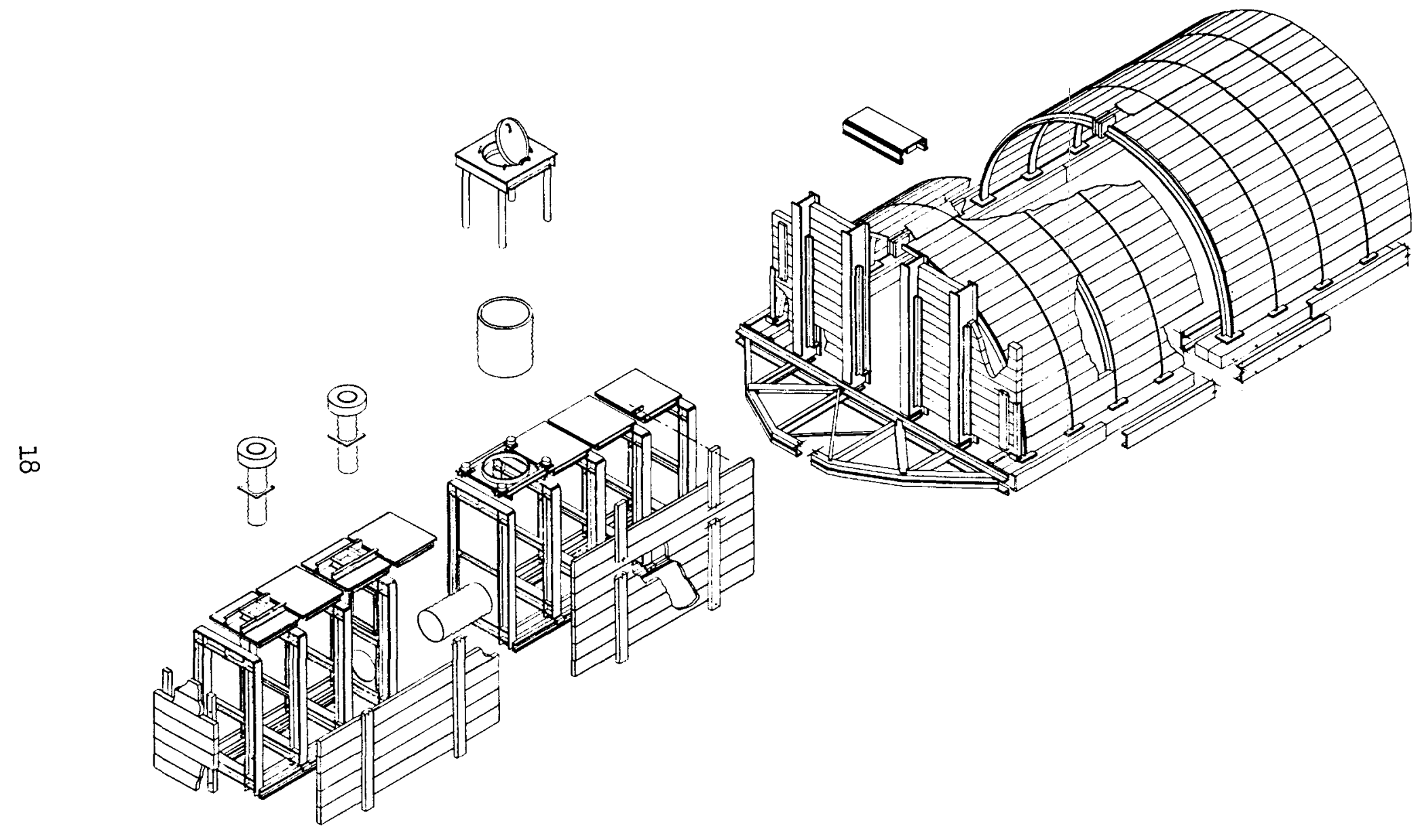

Figure 1.2 Exploded view of the field shelter and entrance complex. 
Five ${ }^{1}$ tests (Shots 1 to 5 ) were conducted during the test series. With the exception of shot 1, the model was excavated after each test. Shot 2 was a repeat loading of the shot 1 configuration. On excavation after each shot, all damaged components and all fasteners (nuts, bolts, etc.) were replaced.

\subsection{STRUCTURE}

2.1.1 General Description. The design of both the prototype and the model is described in detail in References 1 and 2 , the model (hereafter called the structure) being a scale (1/4.5) version of the prototype. The physical properties of the steel, wood, etc., used in construction of the structure are given in Reference 3. The structure is a free-end arch composed of steel inverted-tee ribs spanned by timber elements. The footings are made of timber held together by steel channel elements. The ends of the structure are closed by means of bulkheads composed of four steel Ibeam uprights filled between with timber elements. Reaction at the base of the I-beams is taken by a steel end truss reacting on the footing ends.

Assembly of the structure, and in like manner the prototype, is initiated by assembling and placing the two footings (Figure 2.1a). Each footing is assembled by bolting steel channels on both sides of timber sills. The sill timber joints do not coincide with the channel joints (Figure 2.la). Next in the assembly process, the arch crown timber is placed, ribs are raised, and end trusses are bolted in position (Figure 2.Ib). To complete the steel construction, the bulkhead beams are raised and bolted (Figure 2.ld). The wooden blocks forming the roof are placed next, and, finally, the wooden block bulkheads are positioned. Figure 2.le

$\bar{I}$

The pilot test was reported in Reference 3 and is not considered to be part of this series. However, the data obtained from the pilot test are included whenever data plots are shown since they are pertinent. 
shows an end view of the structure bulkhead, and Figure 2.If shows the model with a section of the arch roof removed.

2.1.2 Arch Ribs. The arch ribs were fabricated from 6 by $1-7 / 8$ junior beams, each beam being ripped down its length and then trimmed to form a 1.09-inch-deep tee section. All dimensions were held to \pm 0.005 inch. To form the required arch, the tee angle sections were cold rolled using special roller adapters to prevent distortion of the stems and outstanding angle legs. Bearing plates were welded to the structural tee to complete the rib fabrication.

2.1.3 Wooden Elements. All wooden elements were made of clear coastal-region Douglas fir. Besides the footings, the other wooden elements were the crown timber running the length of the arch erown, and the roof and bulkhead blocks. The roof blocks were slightly tapered to conform with the curvature of the roof. The bulkhead blocks were of various sizes to conform to the beam spacing. Two short blocks were required because of the rib joint at the crown.

2.1.4 Bulkhead and Truss. The bulkheads consist of four main vertical beams and two small columns, one at each footing. These beams bolt to a truss at their base, which, in turn, reacts against the ends of both footings. There are four bolts at the base of each beam connecting the beam and the truss. The beams and truss are shown in Figures $2.1 c$ and 2.1d. The spaces between the beams are filled with the bulkhead blocks (described in Section 2.1.3) which are held in place by a pair of angles welded to the centers of the beams.

\subsection{TEST CONFIGURATION}

2.2.I Test Device. The tests reported herein were conducted in the LBIG, a device that will simulate the blast effects of a nuclear device. It is used primarily for testing semihard underground protective structures and can produce airblast overpressures to $500 \mathrm{psi}$ on a 23-foot-diameter by 10-foot-deep soil specimen. Basically, the LBLG consists of four major components (1) Central Firing Station (CFS), (2) test chamber, (3) firing tube assembly, and (4) platen and rail-lift mechanism.

The CFS is a massive concrete structure, reinforced in three 
directions with prestressed steel rods and cables. It is essentially a rectangular block with an opening through it and serves as a reaction structure for the test chamber.

The test chamber which contained the structure is formed by stacking three large steel rings, one on top of the other, on a movable platen. After soil, structure, and instrumentation placement is completed, the ring containing the firing tubes and the chamber bonnet or lid are set in place. This assembly is rolled into the CFS, and the platen is lowered to the floor, after which the top ring is raised to rest firmly against the ceiling of the CFS. The test is then conducted by detonating the explosive charges placed previously in the firing tubes. Primacord (pentaerythritol tetranitrate) is used as the explosive charge. The firing tube assembly consists of 15 cylindrical steel tubes, perforated with numerous round holes to permit the escape of the gases generated by the detonation of the explosive. A rigid grid of baffle plates supported below the firing tube assembly provides support for the assembly and serves to smooth out the blast wave that is generated.

A detailed description of the test device and its supporting equipment is given in Reference 4, and a detailed evaluation of the free-field response is given in Reference 5 .

2.2.2 Test layout. All tests were conducted in the LBLG with the test chamber filled with sand to a height of 10 feet. The surface of the sand specimen was covered with an 8-mil plastic membrane material which was in turn covered by a 2-inch sand layer to prevent burning. The plastic membrane was also used to seal the structure to prevent sand from filtering into the structure interior. The location of the structure in the test chamber is shown in Figure 2.2. The depth of crown cover was $11-1 / 32$ inches, Which corresponds to a depth of one-fourth the diameter of the structure. The total depth to the lower surface of the footing was 35-5/32 inches.

2.2.3 Specimen Construction. Two methods of sand placement were used during the construction of each test configuration. Below the level of the structure footings, the sand was placed in 6-inch lifts with each being vibrated. After the structure was assembled in the IBLG and the free-field instrumentation was placed, a sprinkling technique was used to build the 
remainder of the sand specimen to avoid any risk of damage to the extensive instrumentation. During this process, the sand is dropped through a series of nozzles and a screen with a drop height of approximately 30 inches. A vibrator is used on the side of the sand hopper to promote sand flow through the nozzles. A detailed description of this placement method can be found in Reference 6 .

Soil tests were conducted to determine the in situ physical properties of the sand surrounding the structure prior to each test. It was determined that the uniformity using the placement techniques described above was good, with a slightly lower density resulting from vibration than from sprinkling. The density data are tabulated in Table 2.1. Static platebearing tests were conducted at footing level to obtain load-carrying data at this level. These data are shown in Figure 2.3.

\subsection{SOIL PROPERTIES}

The sand used as the backfill during these tests was obtained from a natural deposit along the Big Black River in Warren County near Yokena, Mississippi, and is locally called Reid-Bedford model sand. This sand is a clean, uniform, fine sand (classified as SP according to the Unified Soil Classification System) with particles that are partly subangular and partly subrounded. The grain-size distribution is shown in Figure 2.4. The effective grain size $\left(D_{10}\right)$ is $0.16 \mathrm{~mm}$, and the uniformity coefficient is 1.15. The specific gravity of the solids is 2.65. The minimum and maximum densities are 86.0 and 105.3 pcf, respectively, which correspond to void ratios of 0.924 and 0.570 . The relation between the angle of internal friction and relative density is shown in Figure 2.5. This relation was obtained from a series of stress-controlled, consolidated-drained, directshear tests at several initial relative densities under normal pressures of 1, 3, and $6 \mathrm{kips} / \mathrm{ft}^{2}$. One-dimensional static confined compression curves are shown in Figure 2.6 .

A series of tests was conducted on this sand by United Research Services, Inc. (Reference 7), to determine its dynamic characteristics. A test device which had relatively rigid confining boundaries was used to obtain the one-dimensional stress characteristics of the sand. Quasi-static 
(loading rate too slow to produce wave phenomenon) and dynamic (based on rave propagation) stress-strain results are shown in Figure 2.7. Stress wave propagation velocity and peak particle velocity data are shown in Figure 2.8 . 
TABLE 2.1 PRESHOT SOIL DENSITIES

Shot 2 was a repeat loading of the Shot 1 configuration; therefore, the structure was not excavated and soil densities were not determined.

\begin{tabular}{|c|c|c|c|}
\hline $\begin{array}{l}\text { Elevation } \\
\text { with Respect } \\
\text { to Footing } \\
\text { Ievel }\end{array}$ & Radius & Direction & Unit Weight \\
\hline feet & feet & & pcf \\
\hline
\end{tabular}

Preshot 1:

$-3.0$

$$
\begin{aligned}
& 6.50 \\
& 6.50 \\
& 6.50 \\
& 6.50
\end{aligned}
$$

$\mathrm{NE}$

100.4

$\mathrm{SE}$

SW

100.5

NW

99.5

0.0 (footing

level)

8.00

8.00

8.00

8.00

$+2.8$

$$
\begin{aligned}
& 9.80 \\
& 9.80 \\
& 9.80 \\
& 9.80
\end{aligned}
$$

N
E
S
$W$

Average $\overline{100.1}$

Preshot 3:

0.0 (footing level)

8.00

8.00

8.00

8.00

IN

E

S

W

Preshot 4:

0.0 (footing leveI)

8.00

8.00

8.00

8.00

$+2.8$

10.00

9.00

9.00

10.00

N
E
S
$W$

100.8

101.0

101.0

100.4

Average 100.8

101.3

100.8

102.4

102.6

Average 101.8

100.0

100.5

99.6

Average 99.9 


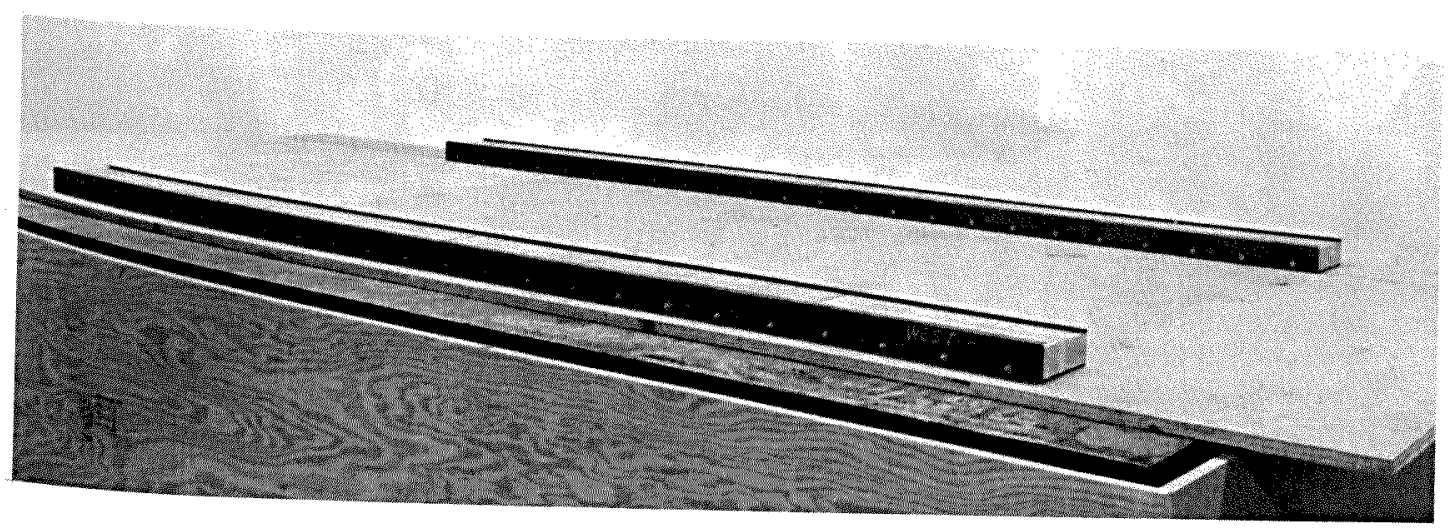

a. Structure footings assembled and in position.

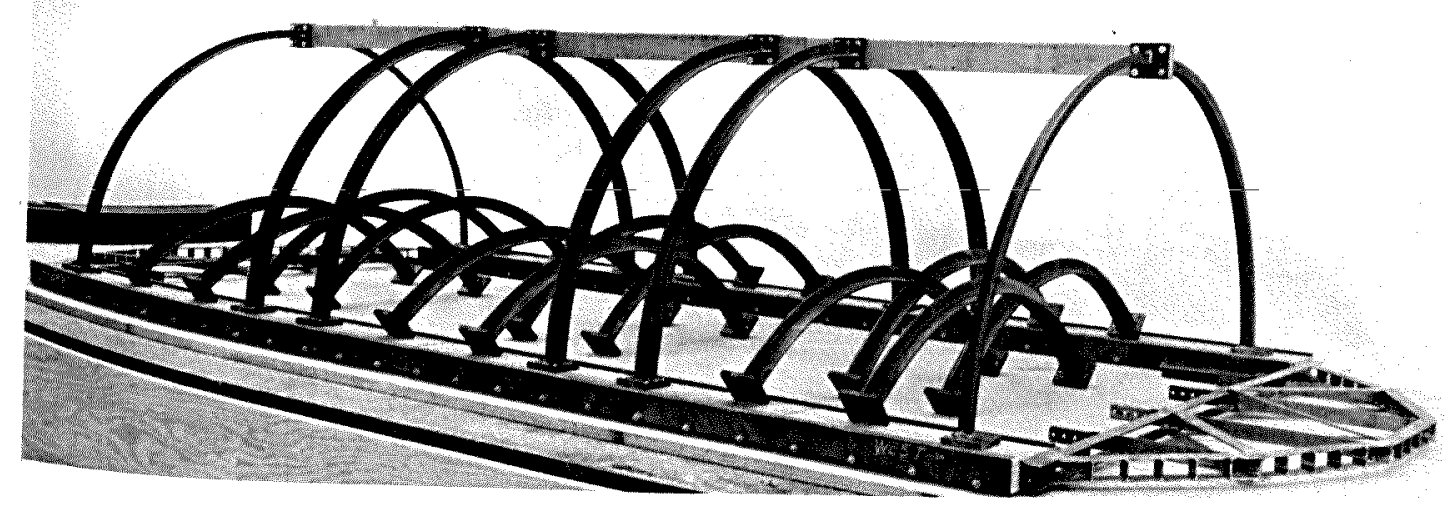

b. Stmacture with crown timber and six ribs in position.

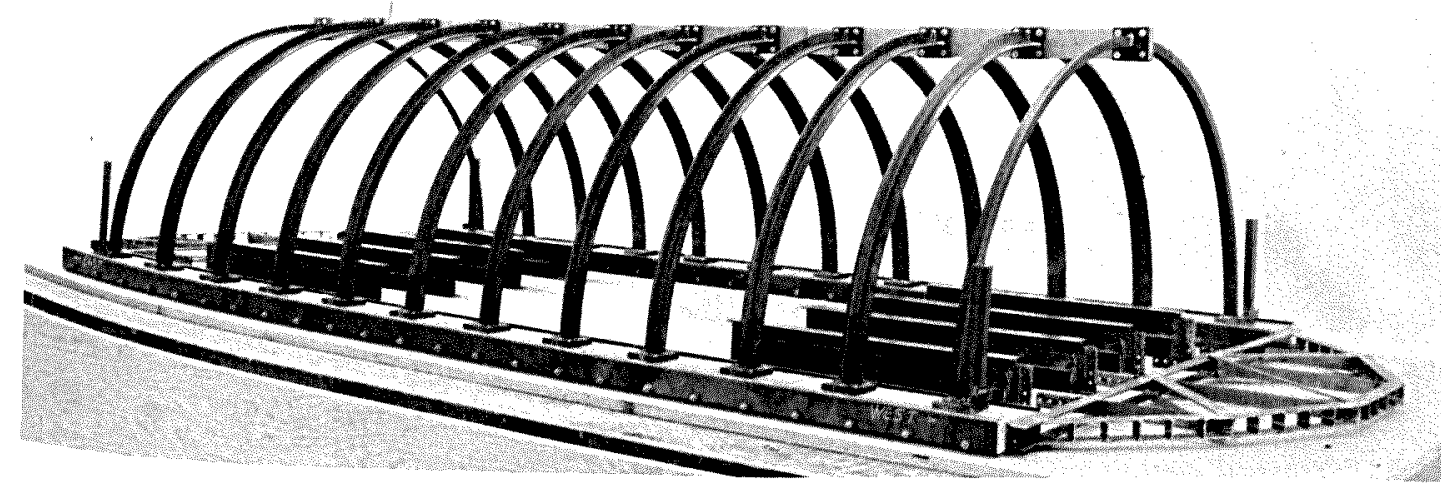
c. Structure with ribs raised and bulkhead edge support
channels.

Figure 2.1 steps in structure assembly (Sheet 1 of 2 ). 


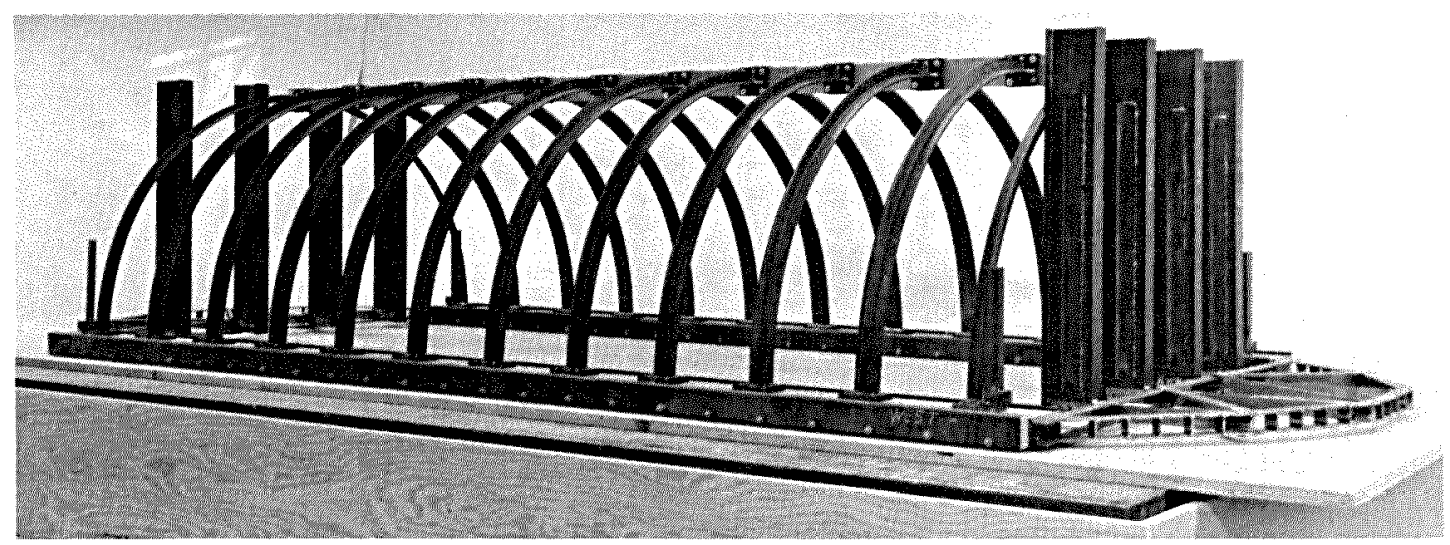

d. Structure with all steel structural elements assembled.

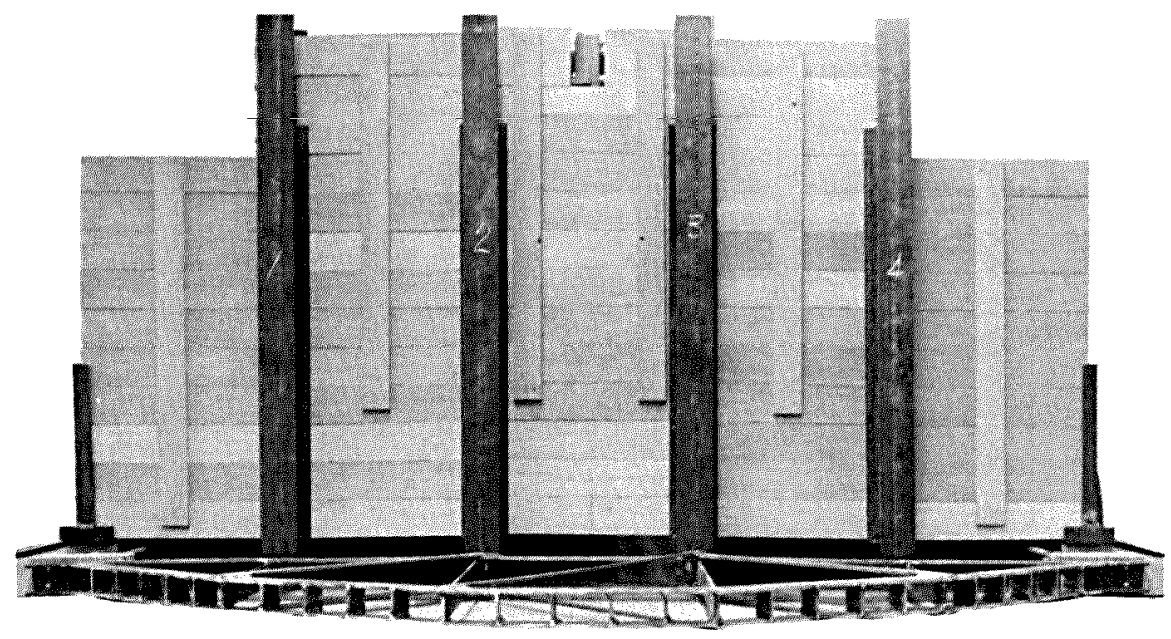

e. Assembled bulkhead.

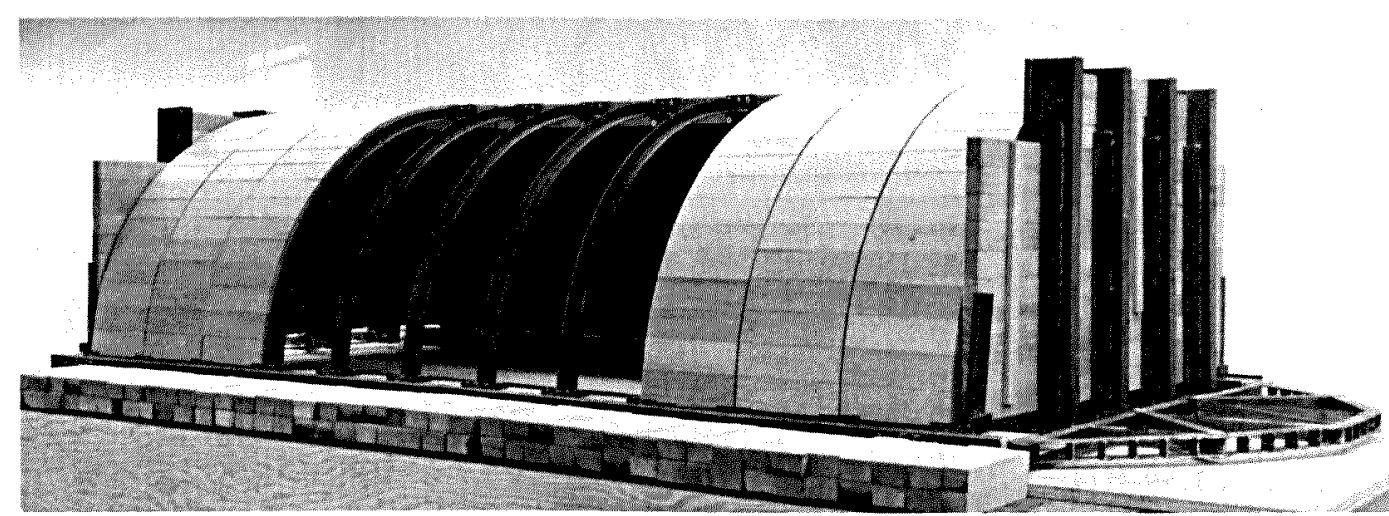

f. General view of stmeture with a portion of the roof lagging removed.

Figure 2.1 (Sheet 2 of 2 ). 

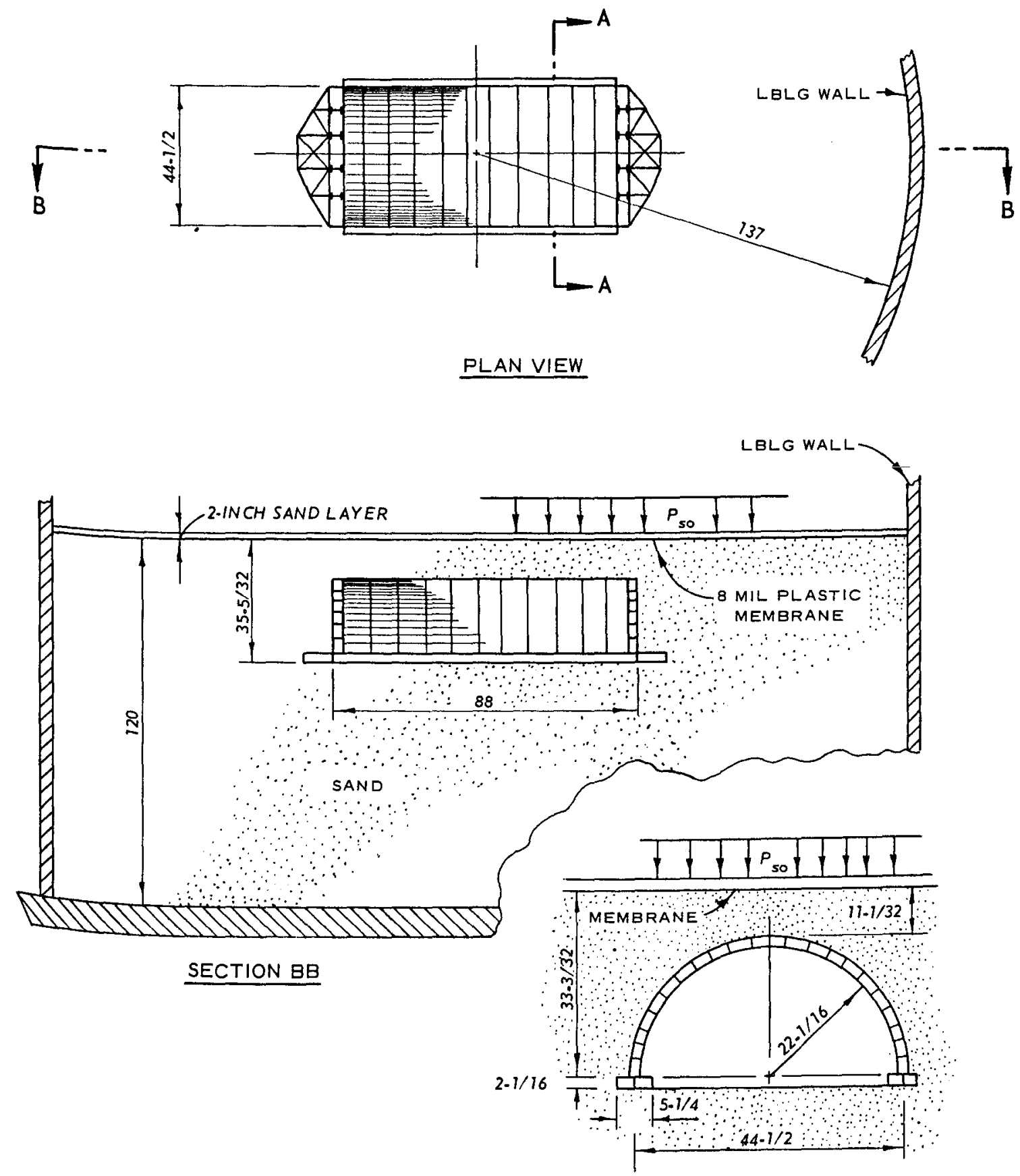

SECTION AA

Figure 2.2 Test geometry and location in the LBLG. Dimensions are in inches. 


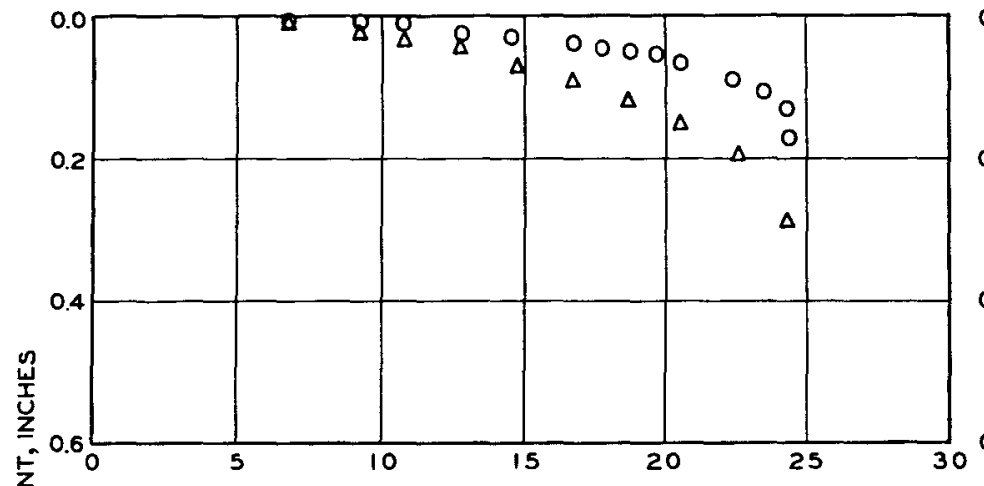

a. PRESHOT 1

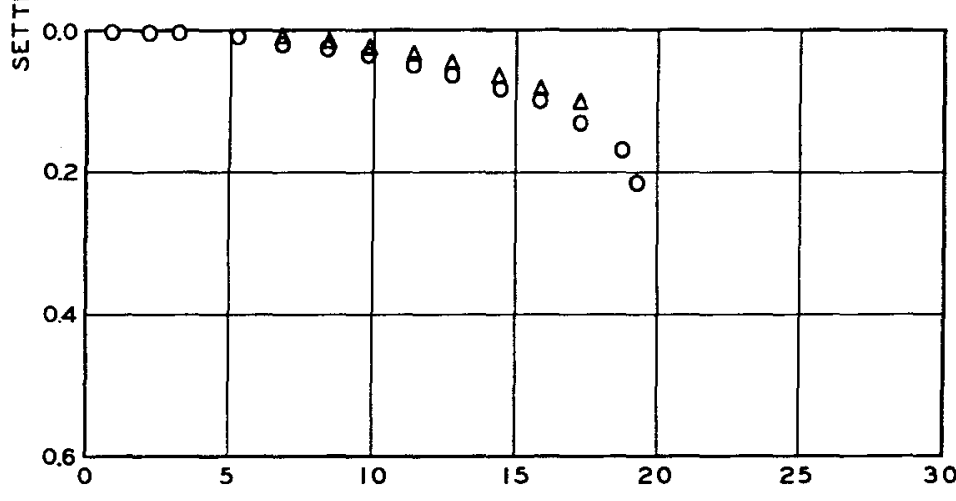

c. PRESHOT 4

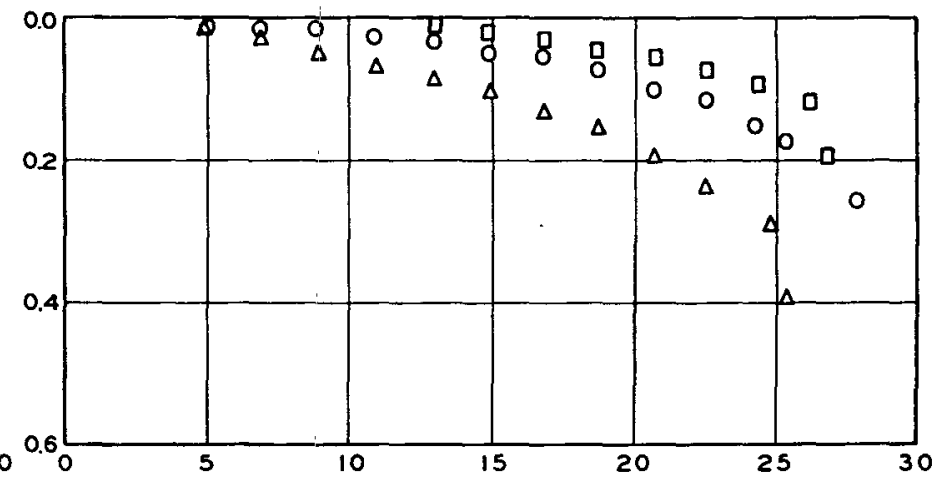

b. PRESHOT 3

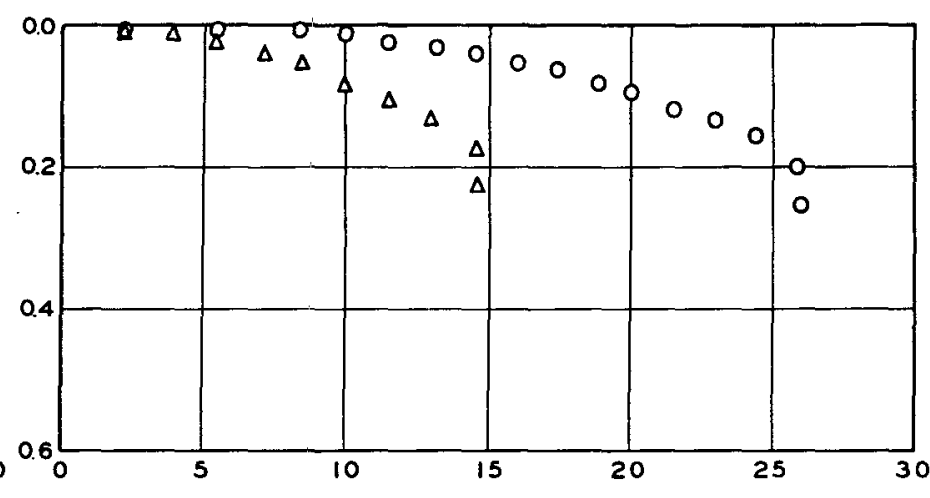

d. PRESHOT 5

Figure 2.3 Plate-bearing test results at footing level. Shot 2 was a repeat loading of the Shot 1 configuration, and plate-bearing tests were not conducted. 


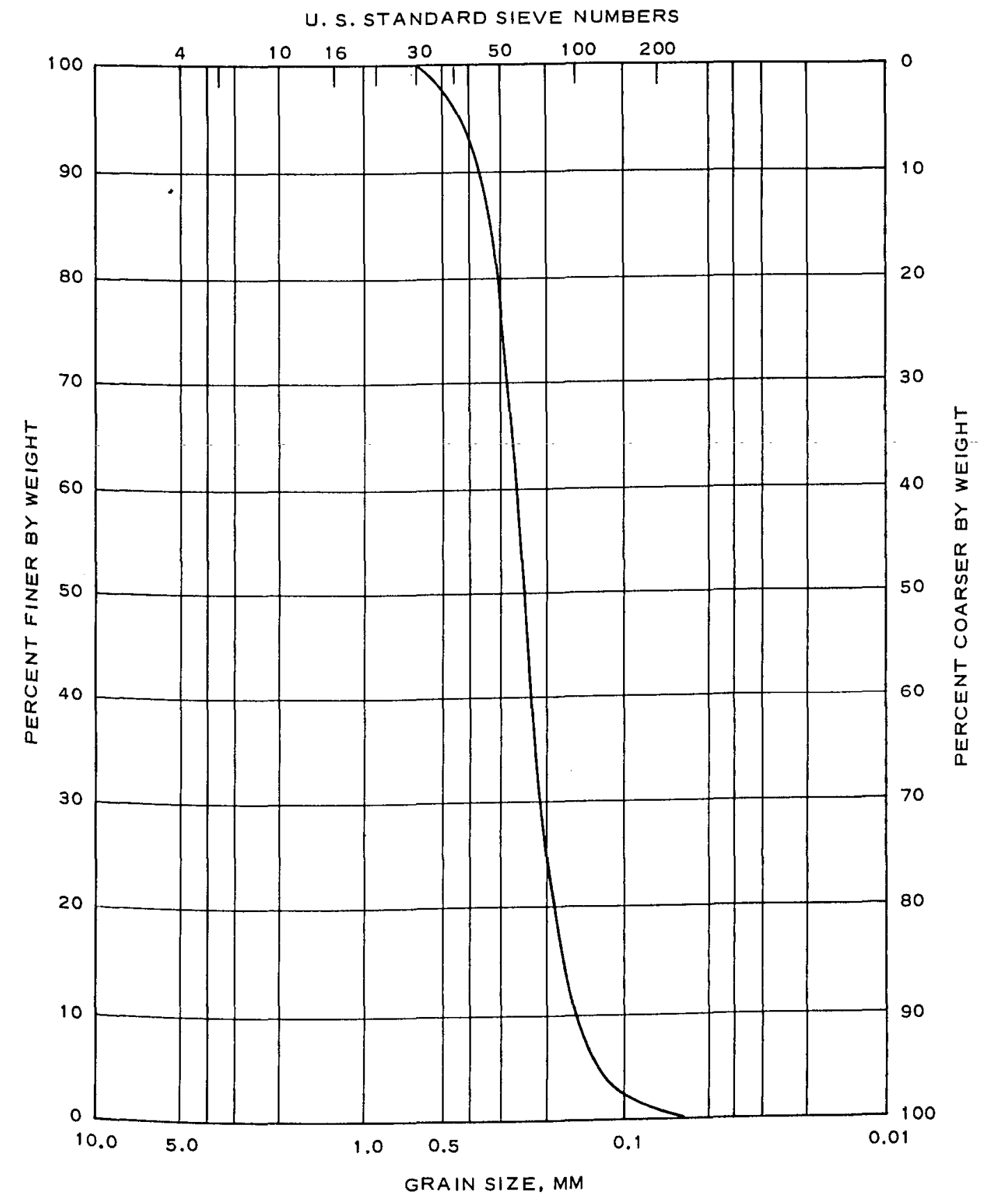

Figure 2.4 Grain-size distribution curve for the test sand. 
INITIAL DRY DENSITY, PCF

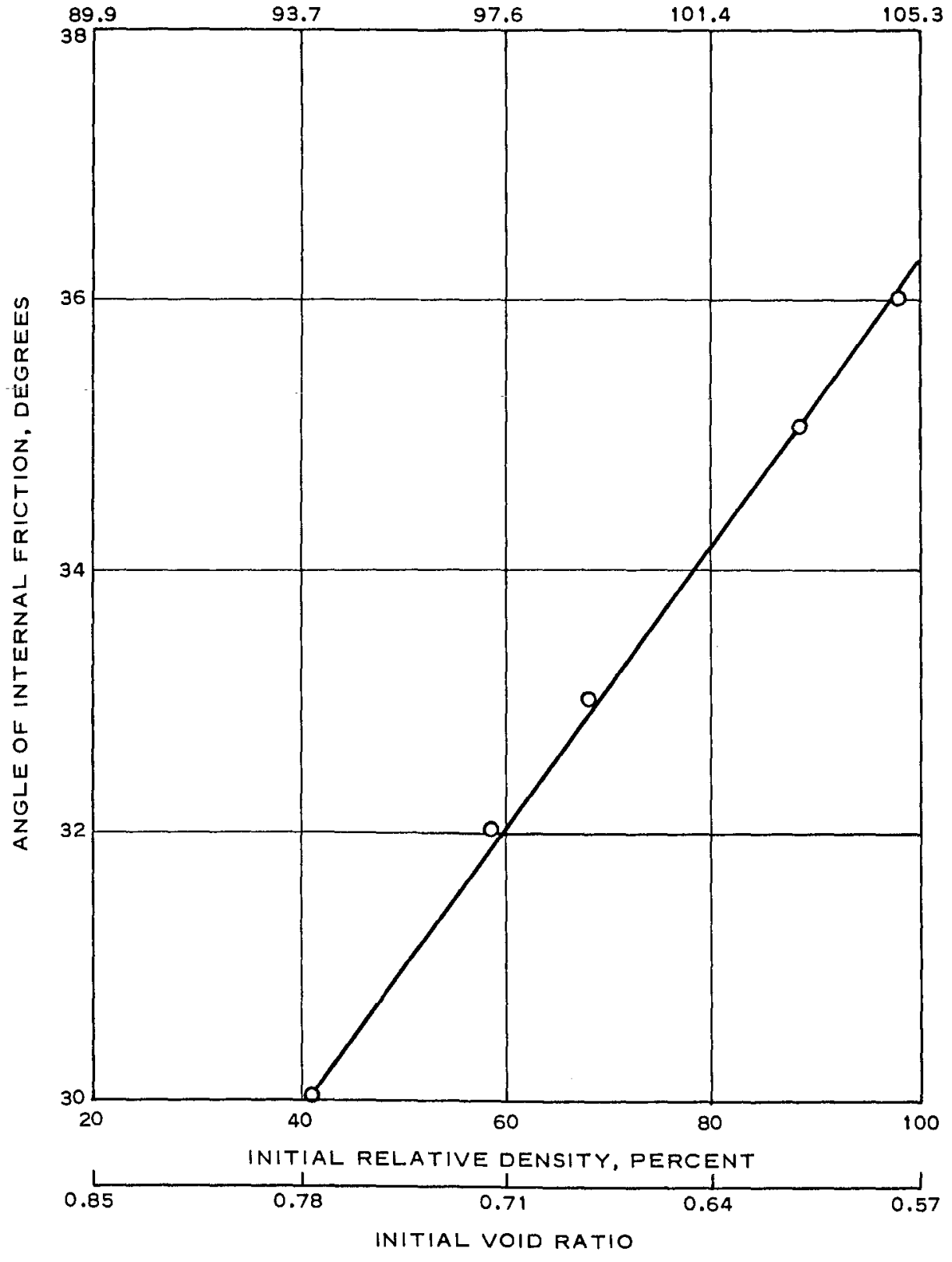

Figure 2.5 Relation between angle of internal friction and density for the test sand. 


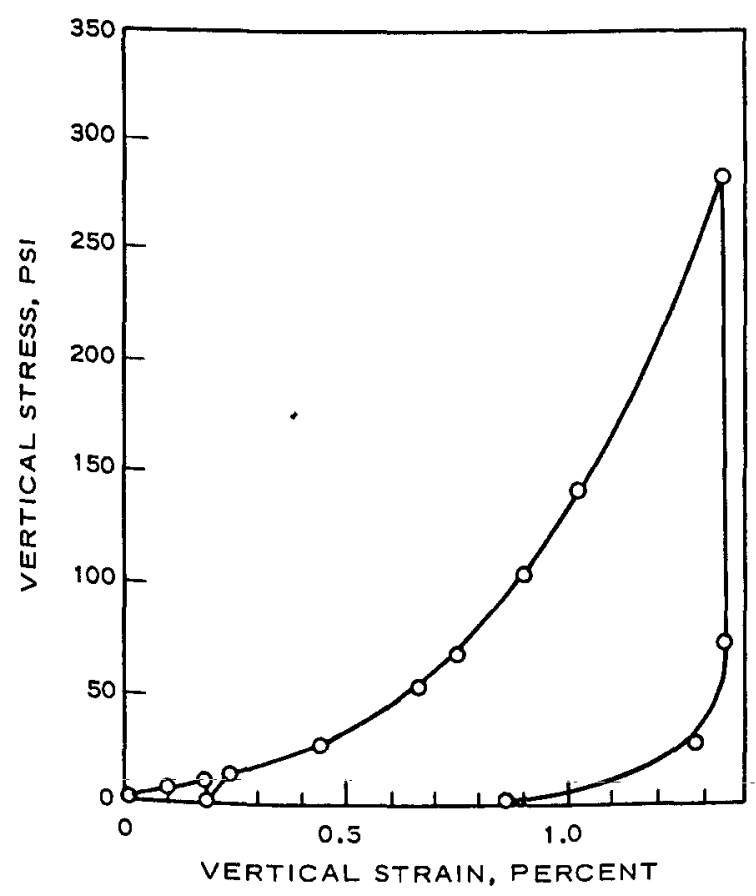

a. 96.7-PCF INITIAL DRY DENSITY $\left(D_{r}=55 \%\right)$

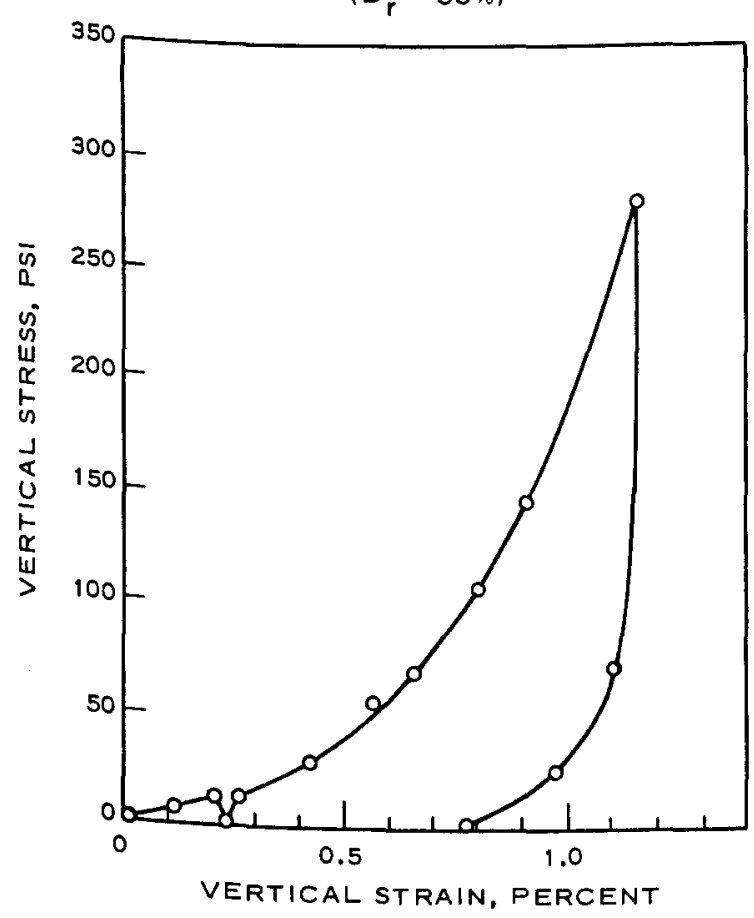

c. 100.8-PCF INITIAL DRY DENSITY $\left(D_{r}=77 \%\right)$

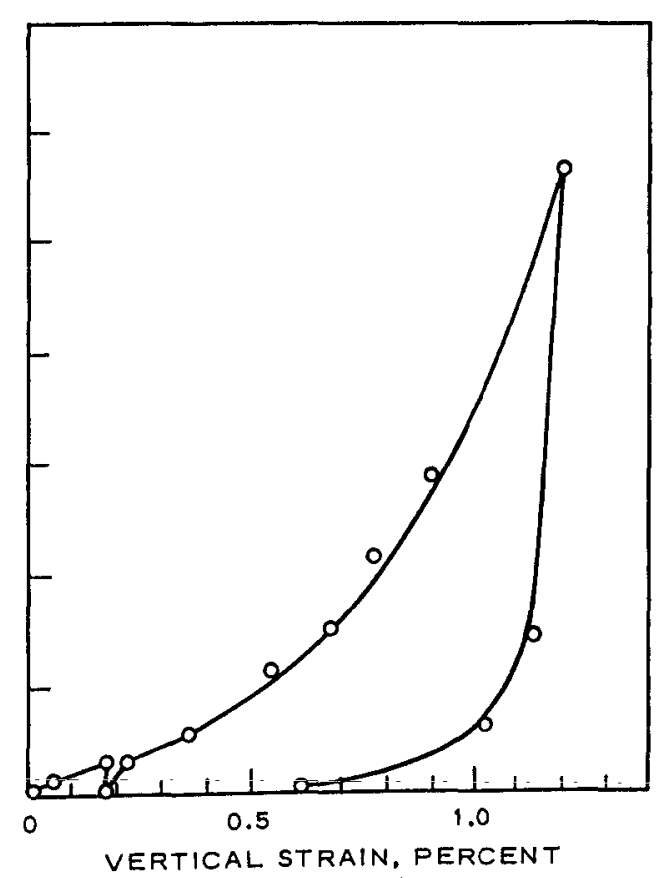

b. 99.6.PCF INITIAL DRY DENSITY $\left(D_{r}=70 \%\right)$

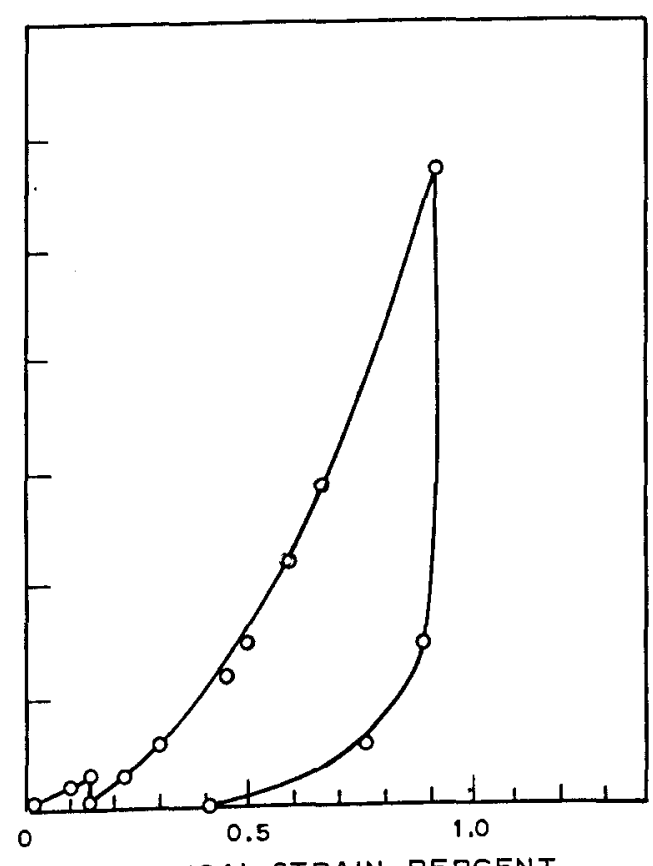

VERTICAL STRAIN, PERCENT

d. 103.0-PCF INITIAL DRY DENSITY $\left(D_{r}=90 \%\right)$ Figure 2.6 One-dimensional static confined compression test data for the
test sand. 


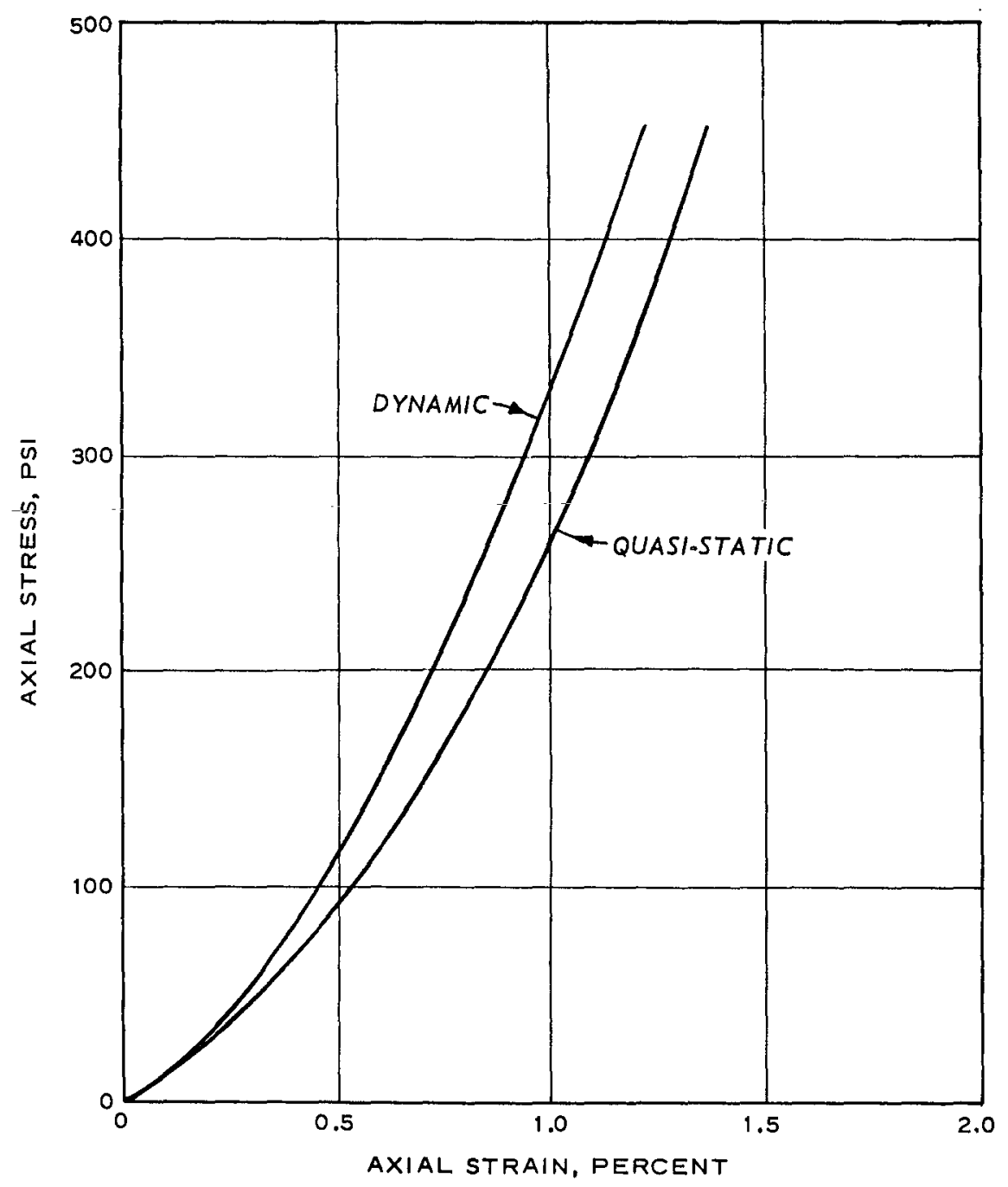

Figure 2.7 Stress-strain curves for the test sand; density 99.7 pcf. 

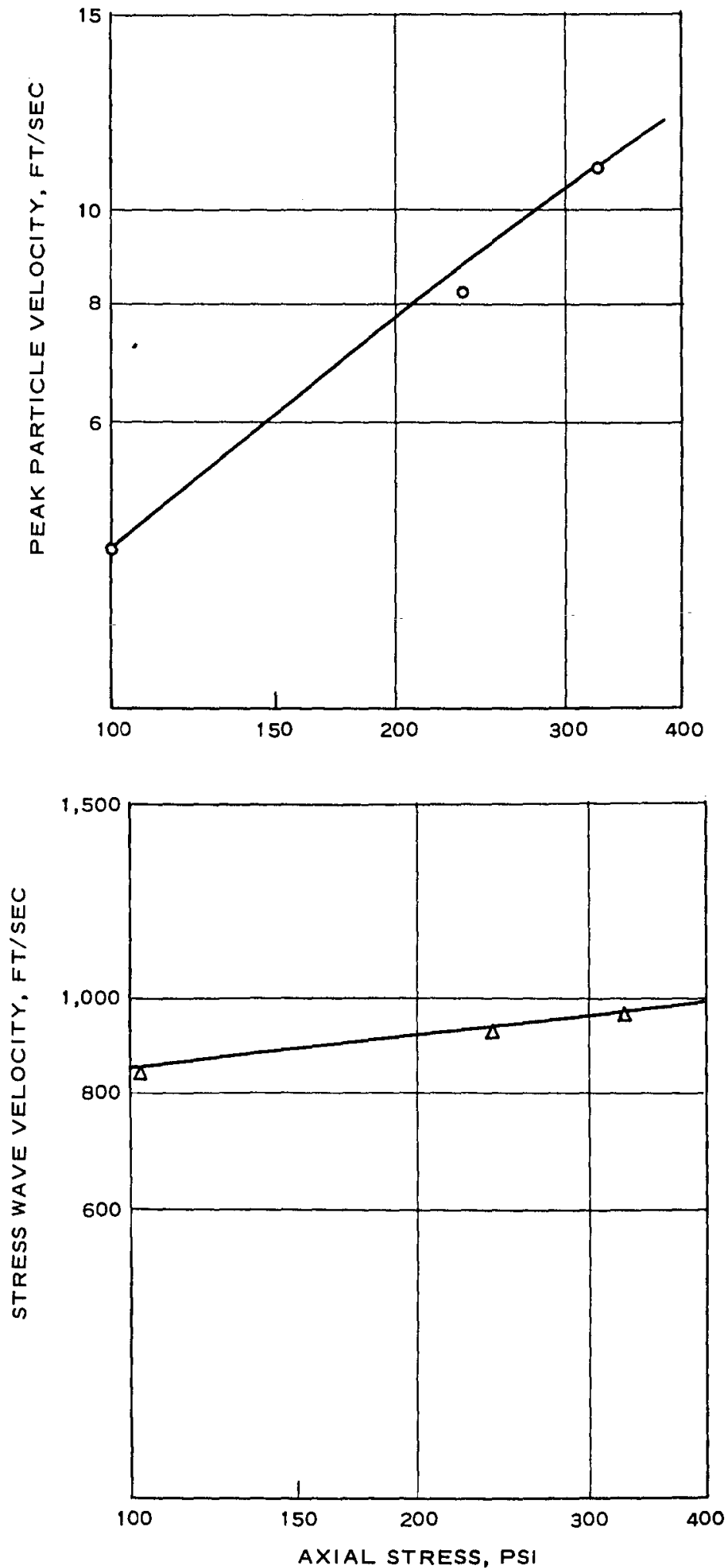

Figure 2.8 Velocity data for the test sand; density 99.7 pef. 


\section{RESULTS}

The data results of this study are presented in tabular form in Appen$\mathrm{dix} A$, Appendix B contains time histories of the test records, and Appendix $\mathrm{C}$ contains computed data based on the raw data. Typical records are presented throughout the main text of this report whenever their inclusion is believed of value to the reader.

\subsection{LOADING INPUT}

3.1.1 Surface Airblast. Typical of the surface airblast overpressure $\left(\mathrm{P}_{\mathrm{so}}\right)$ histories is the presence of a number of small shocks during approximately the first $10 \mathrm{msec}$ of response. These shocks are due to reflections occurring within the baffle and firing tubes and are a result of the pressure-generation geometry. The action of the soil is such that it tends to smooth out the airblast wave as it is transferred into and propagates through the soil. This being true, the presence of the high-frequency spikes in the airblast wave has little effect on subsurface structures; consequently, a relatively smooth pressure signature was determined for each shot in the test series by dividing the overpressure histories into a number of time increments, selecting a mean pressure value for each time increment, being careful to preserve impulse, and constructing a smooth curve using the mean values. Based on the individual smoothed curves, a composite surface airblast overpressure history was constmucted for each shot by averaging all the individual smoothed peak pressures to arrive at a peak surface airblast overpressure. Using this peak value, all of the smoothed curves were normalized and averaged together to give the composite surface airblast overpressure curves shown in Figure 3.1. The composite peak pressures are close (within 10 percent) to those predicted, based on total weight of explosive used, and show a difference of not more than 10 percent in the values averaged to obtain the normalizing peak overpressure.

Certain of the recorded data were judged invalid, and these data were not considered in the construction of the composite curves. If an individual smoothed peak pressure was appreciably (50 percent) higher or lower 
than predicted based on explosive weight it was eliminated. For example, in the case of Shot 4 only record BP(6965) was used since both SPI and SP2 indicated pressures even lower than shot 3. During the period of shot 4 almost all of the airblast transducers were diverted from the Blast Load. Generator Facility for use on a high-priority field test. The record for Gage BP(6965) does not appear to have been reliable much past peak as can be seen when comparing the impulse curves for the various shots (Figure 3.2). This figure shows the impulse for shot 4 was less than that for Shot 3 which was a lower energy shot. The impulse data indicate that with the exception of Shot 4, the impulse increased as expected.

A portion of the tape playback for Gage SPI, Shot 3, is shown in Figure 3.3 along with the condensed composite record for shot 3 . The only sets of pressure records indicating duration were obtained for shots 3 and 4. Generally, the high temperature at the soil surface causes the pressure gages to begin drifting after about $400 \mathrm{msec}$, and eventually to register a negative pressure. On shot 3 this did not occur and some confidence can be attached to the duration observed. A duration was observed in shot 4 without negative pressure registration, but the poor impulse correlation raises some doubt as to the validity of this duration time. Tabulated in Table 3.1 are the surface airblast overpressure parameters as measured for each shot.

3.1.2 Free Field. Free-field stress and acceleration data were taken during the test series. Shots 3 and 4 were extensively instrumented while Shots 1, 2, and 5 were lightly instrumented. These data are tabulated in Tables $A .3$ and $A .4$, respectively.

3.2 VISUAL DAMAGE SURVEY

3.2.I General Gross Motion and Damage. Shots 4 and 5 were the only tests in which the gross motion of the structure was sufficient to create a noticeable depression of the sand surface in the vicinity immediately above the structure (Figure 3.4). It became evident during excavation of the structure that the depression was caused by the vertical deformation of the steel ribs and downward deflection of the footings. While considerable displacement and deformation of the structure were noted after 
Shot 3, no definite depression was observed. Shown in Figure 3.5 is a sequence of photographs showing the structure crown curvature after shots 3 , 4, and 5 .

3.2.2 Component Damage. In every shot, the crown timber suffered damage. It appears to have been twisted and to have acted like a buffer absorbing some of the thrust forces. At the lower overpressures ( $\mathrm{P}_{\text {so }}$ $<85 \mathrm{psi}$ ), the crown timber split slightly. However, at the higher overpressures, extensive splitting due to twist and crushing occurred (Figure 3.6). No damage was done to the timber lagging until shot 5. During this shot the rib deformation was extensive enough to allow the lagging to bear on the footing and to take some of the thrust loading in compression. This caused some visible compressive damage to the lagging; however, the damage was slight and was structurally insignificant.

The footings were damaged extensively at the high overpressures, but were only slightly damaged at overpressures below $120 \mathrm{psi}$. They generally were bent inward and downward in the central region after each shot. This inward deformation can be seen in Figure 3.7 which shows the damage to the three sets of footings from shots 3 to 5. Parts of the footings for Shot 3 were misplaced and are shown as black dummy sections in the figure. Generally, the damage was greater with increasing overpressure as can be clearly seen in Figure 3.8, a photograph of a section cut through the footing below Rib 9. Also shown in this figure is the deformation of the footing caused by the timber lagging as it was forced into the supporting footing during shot 5 .

Some attempt was made to determine if a significant amount of spalling and motion of the sand floor occurred during shots 4 and 5 . In these shots a tape strip was placed vertically at about the center of the east side of the structure floor to try to measure the extent the sand surface moved upward. Figure 3.9 shows the sand distribution obtained. This record indicates that the interior floor moved up about 1.45 inches and the sand particles were thrown to a height of about 5.40 inches above the original floor level. The tape for shot 5 did not yield favorable results. However, the interior floor accelerometer, 5IVA, was thrown up and displaced from its preshot location below a sandbag (Figure 3.10). This 
accelerometer was not displaced during Shot 4, which indicated, as expected, that the floor was disturbed to a greater degree during Shot 5 . The only serious damage at low overpressure occurred at the connecting bolts between the bulkhead beams and the end trusses. Damage was first noticed here during the pilot test (Figure 3.11), and was initially attributed to insufficient bolt area causing high shearing stresses to occur. Consequently, the bolt sizes for future shots were increased slightly to provide additional shear aréa. During shots 1 and 2 , the same damage occurred (see inset, Figure 3.11). After closer examination, it was decided that the end truss extending out into the free field acted like a paddle, tending to rotate as the structure moved downward. This rotation occurred about the inner bolt and sheared the bolts off starting with the outer one as shown in the inset of Figure 3.11. A redesign of the connection was made using a pin connector which allows rotation. The redesign used the original shear area of the four bolts as the area of the pin and is detailed in Appendix D. Testing was continued using the modified connectors during shots 3, 4, and 5. During shot 3, excessive rotation caused cracks to appear in the tongue between the bulkhead beams and the end truss (Figure 3.12a). Possibly, this distress was due to fatigue since this component had been tested three times previously at lower overpressures. Prior to shot 4, the end truss tongues were replaced and rotation cracks appeared. Again the tongues were replaced and during Shot 5 complete failure occurred (Figure 3.12b). The fact that complete failure did not occur during shot 4 seems to indicate that the shot 3 distress was due in part to fatigue. 
TABLE 3.1 SURFACE AIRBLAST OVERPRESSURE PARAMETERS

\begin{tabular}{cccc}
\hline Shot & Peak Pressure & Duration & Rise Time \\
\hline Pilot & psi & msec & msec \\
1 & 85 & -1.0 \\
2 & 37 & - & 1.6 \\
3 & 67 & - & 1.0 \\
4 & 117 & 956 & 0.5 \\
5 & 143 & 950 & 0.4
\end{tabular}




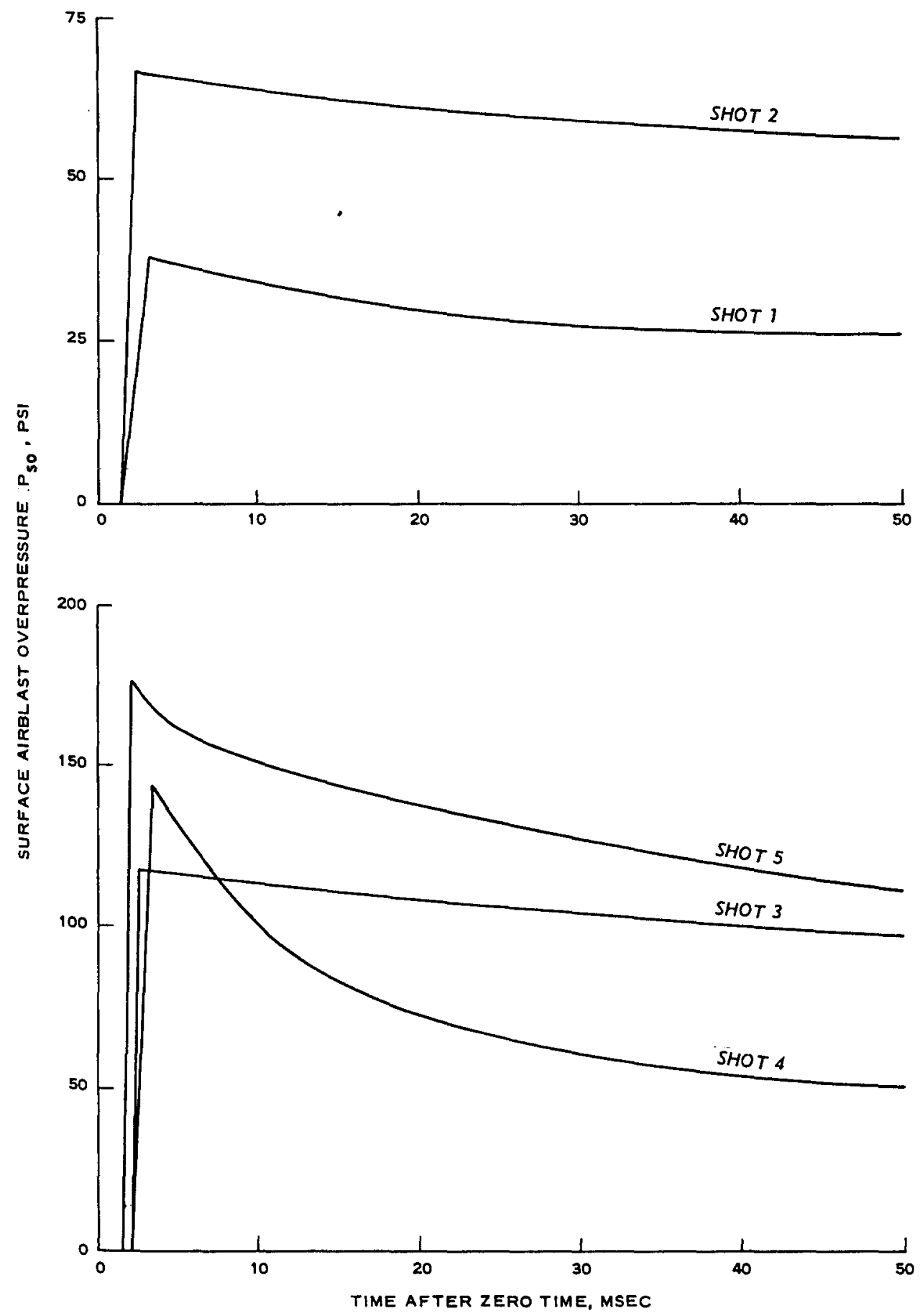

Figure 3.1 Composite surface airblast overpressure curves. 


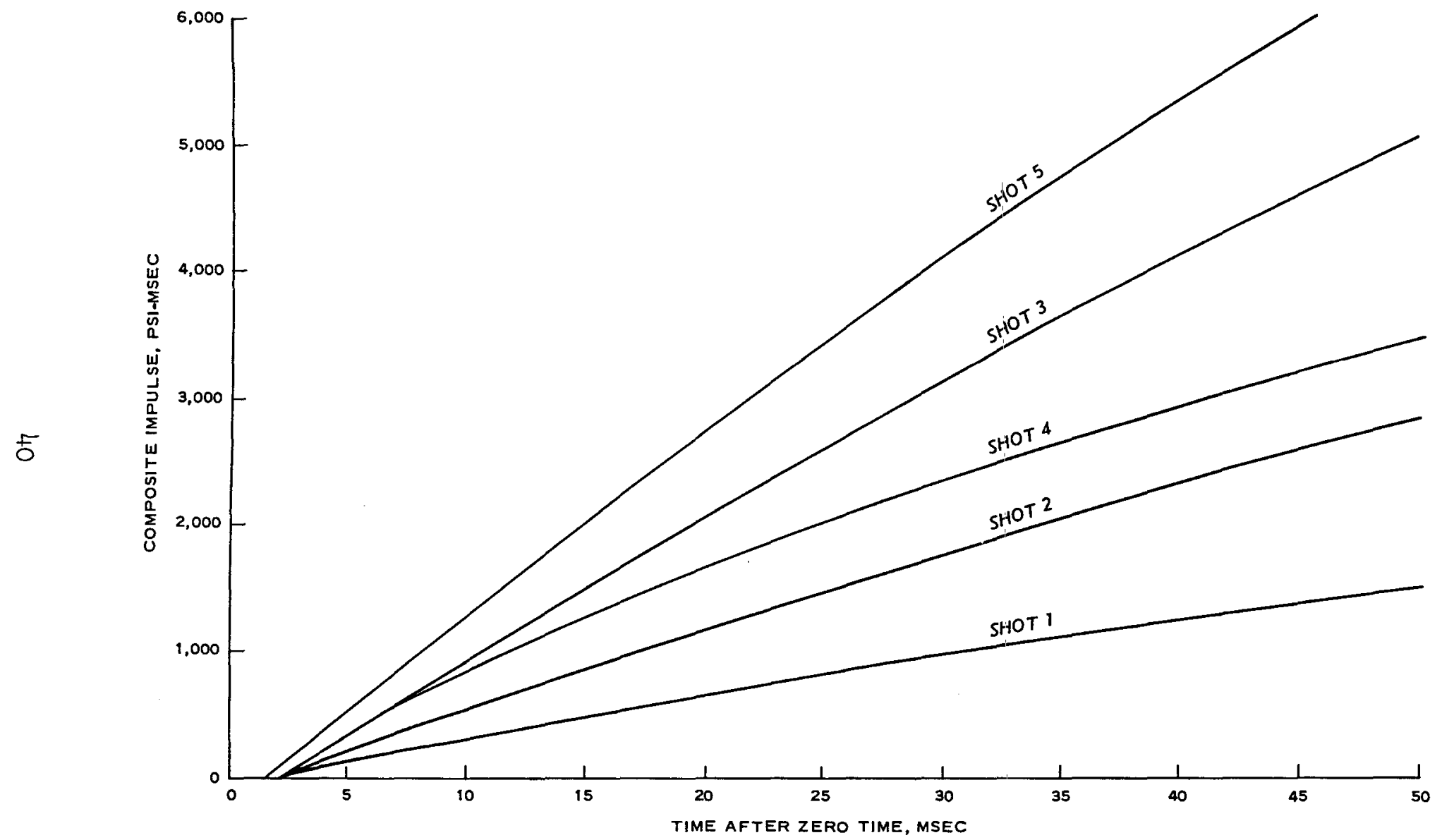

Figure 3.2 Initial impulse data. 


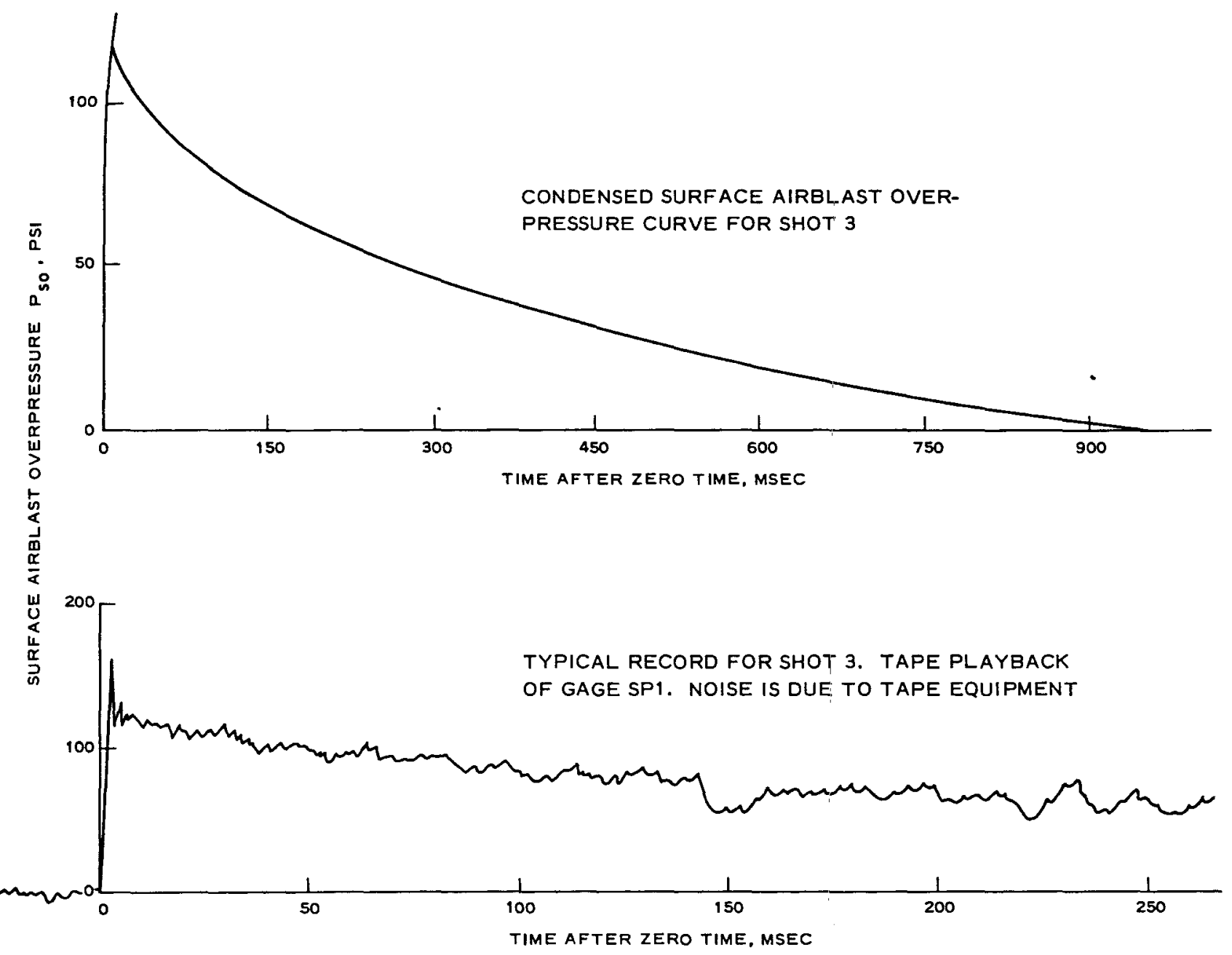

Figure 3.3 Typical airblast data. 


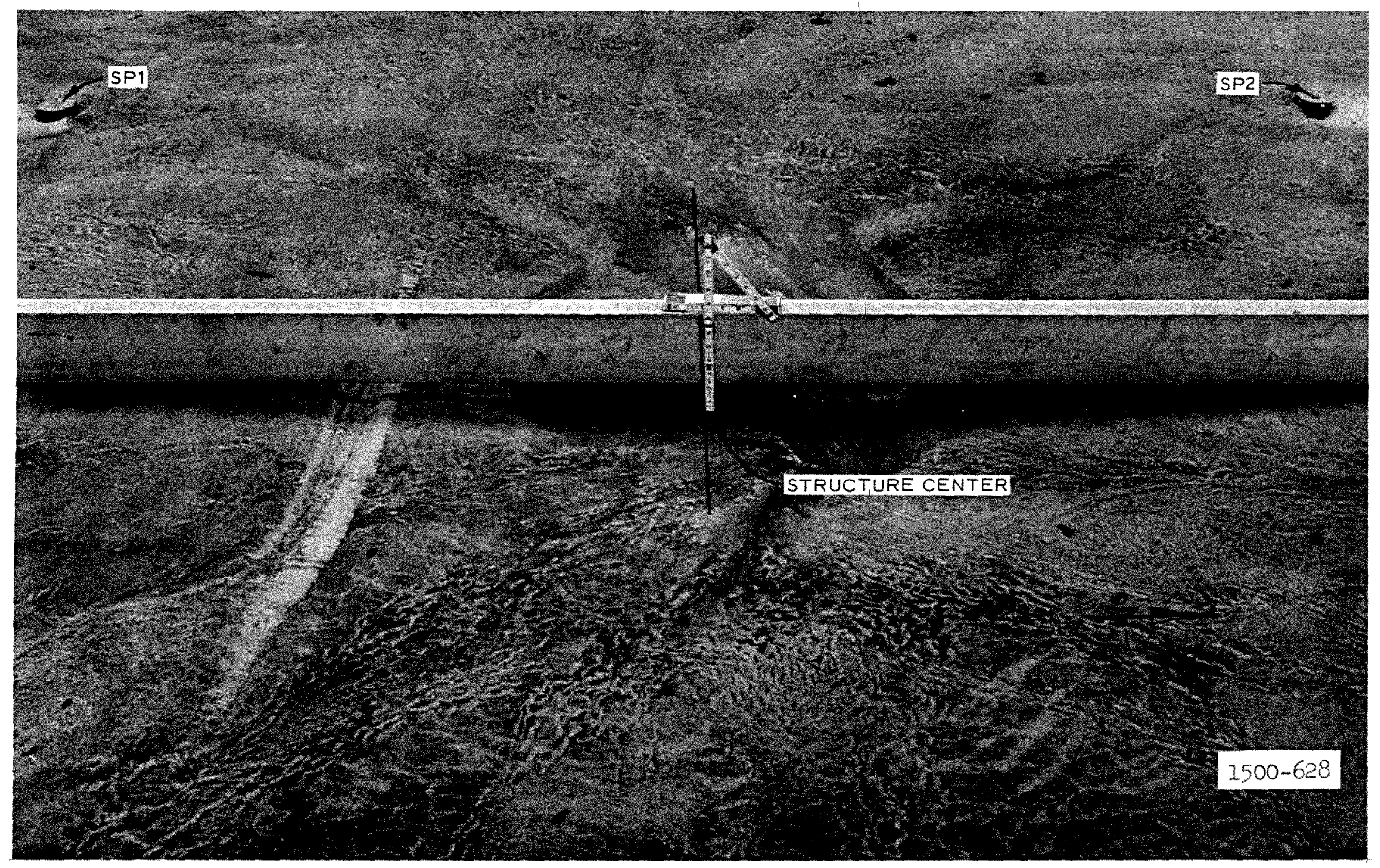

Figure 3.4 Depression in the sand surface caused by the gross motion of the structure during shot 4. Note the presence of airblast Gage SPI in the upper left-hand corner. 


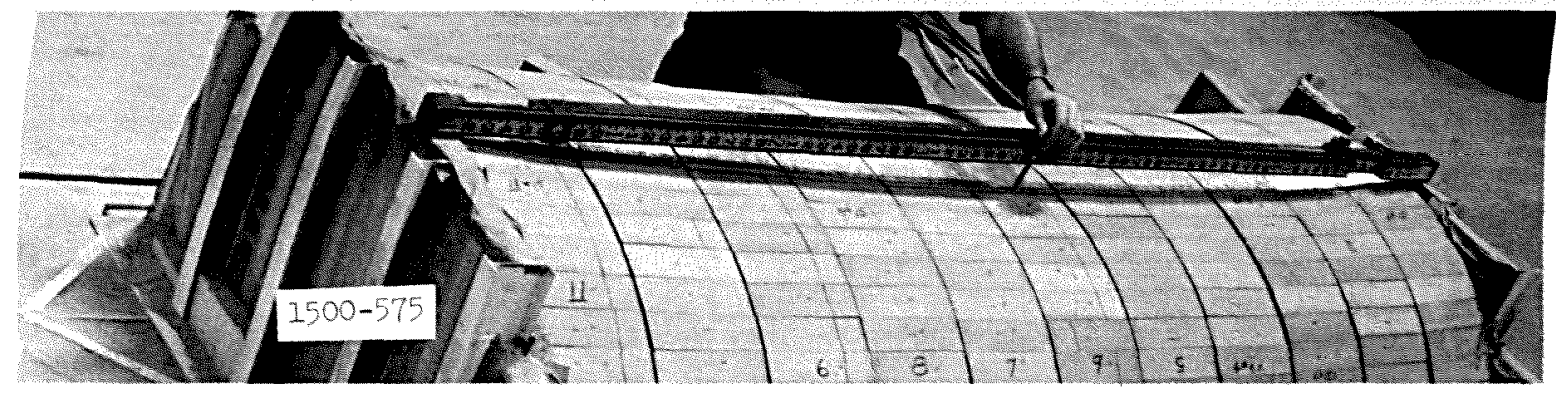

a. Postshot 3 .

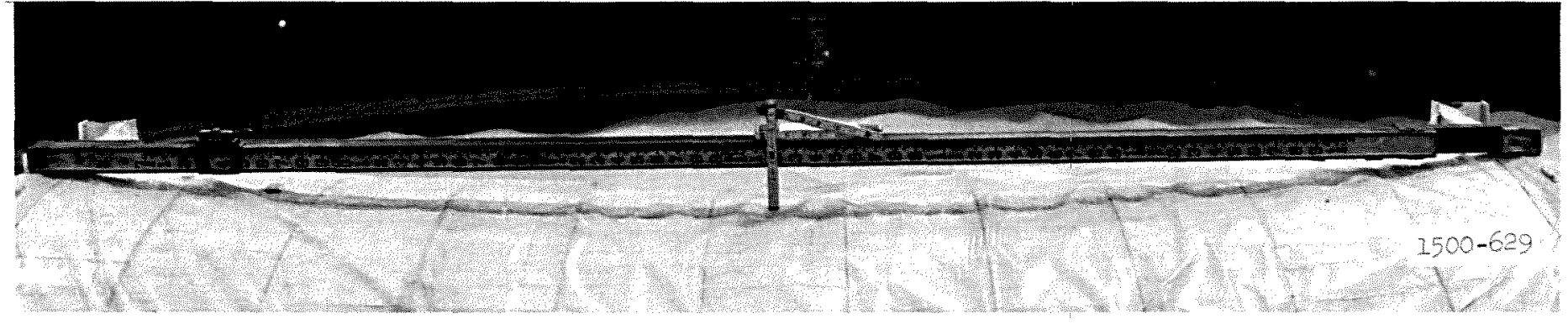

b. Postshot 4 .

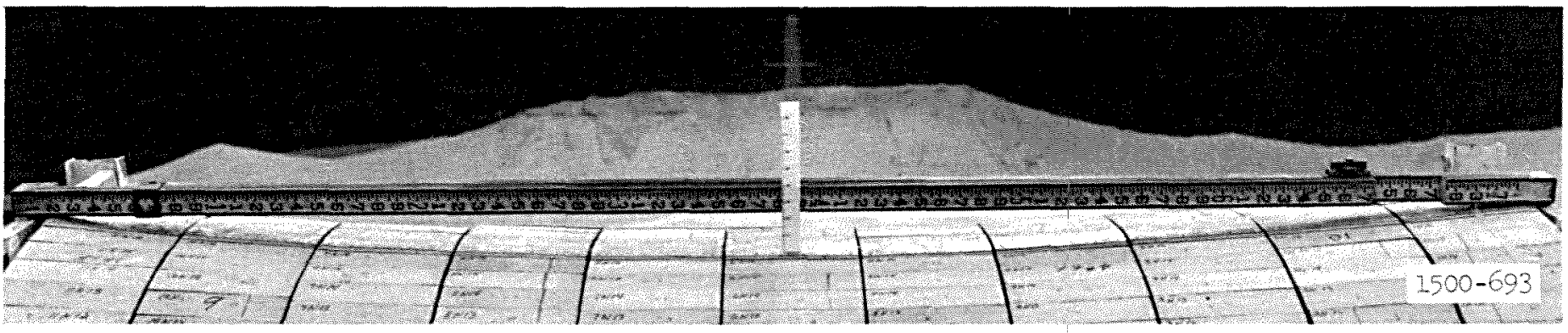

c. Postishot 5 .

Figure 3.5 Postshot crown curvature. 


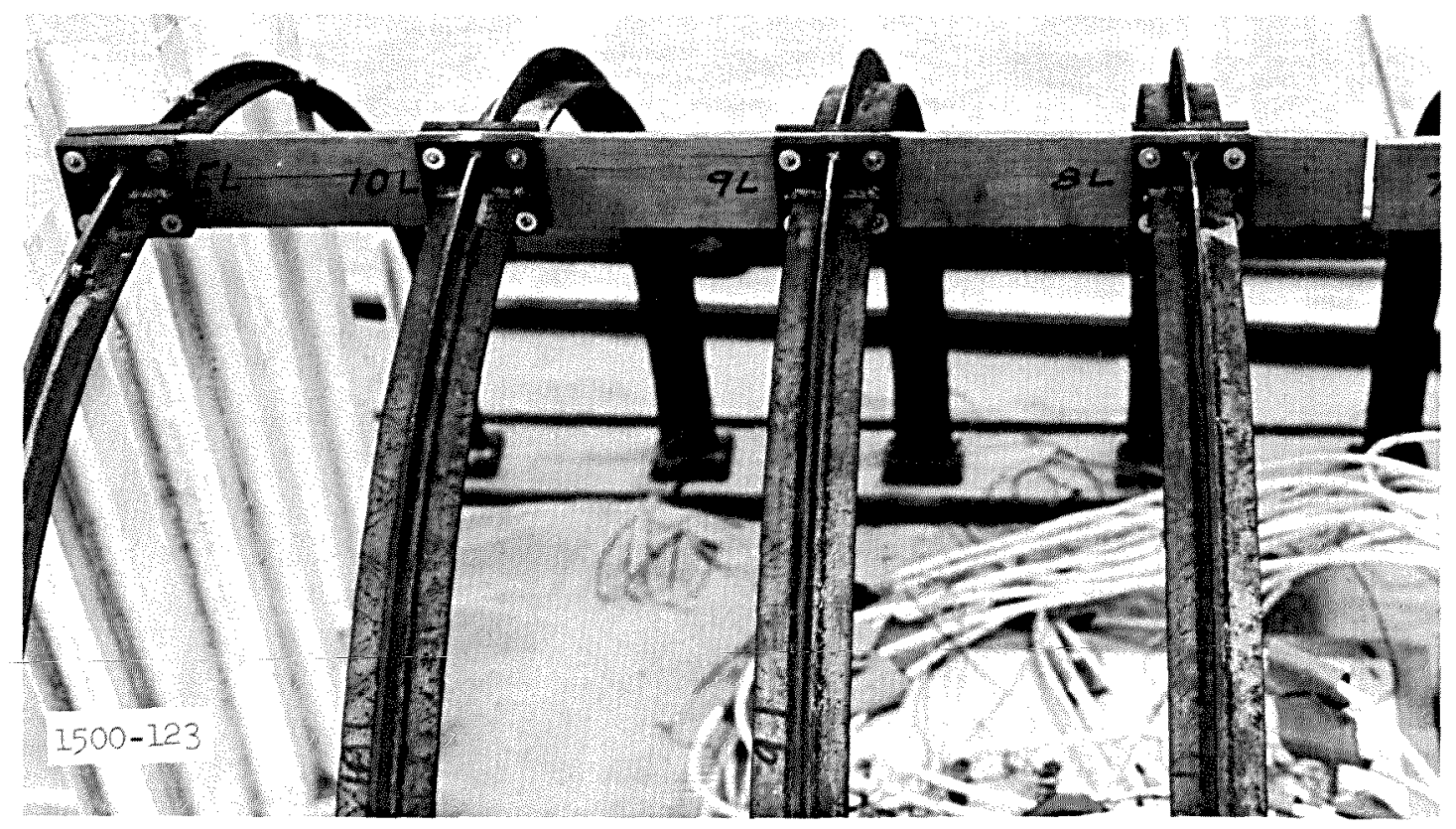

a. Pilot test.

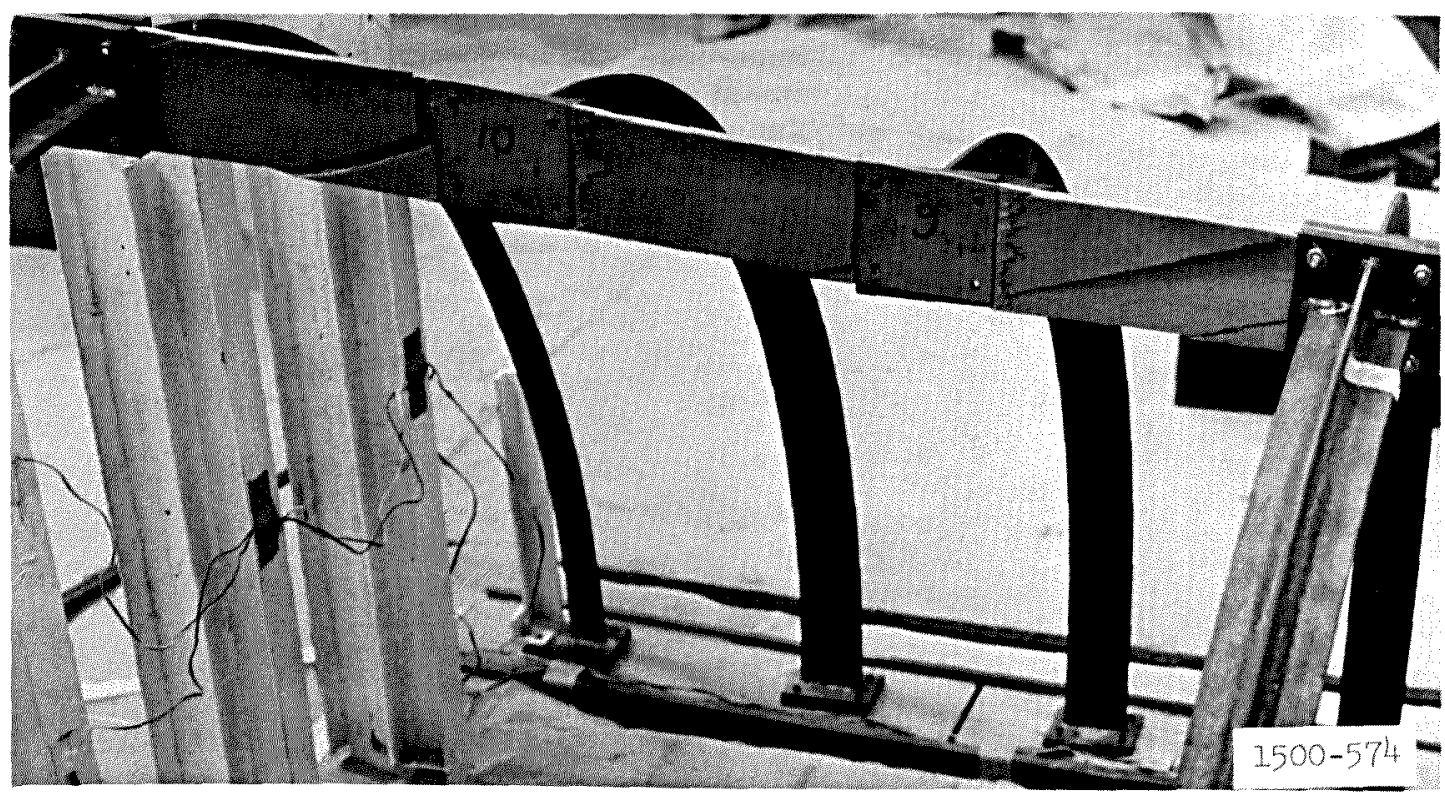

b. Shot 3 .

Figure 3.6 Postshot damage to crown timber. 


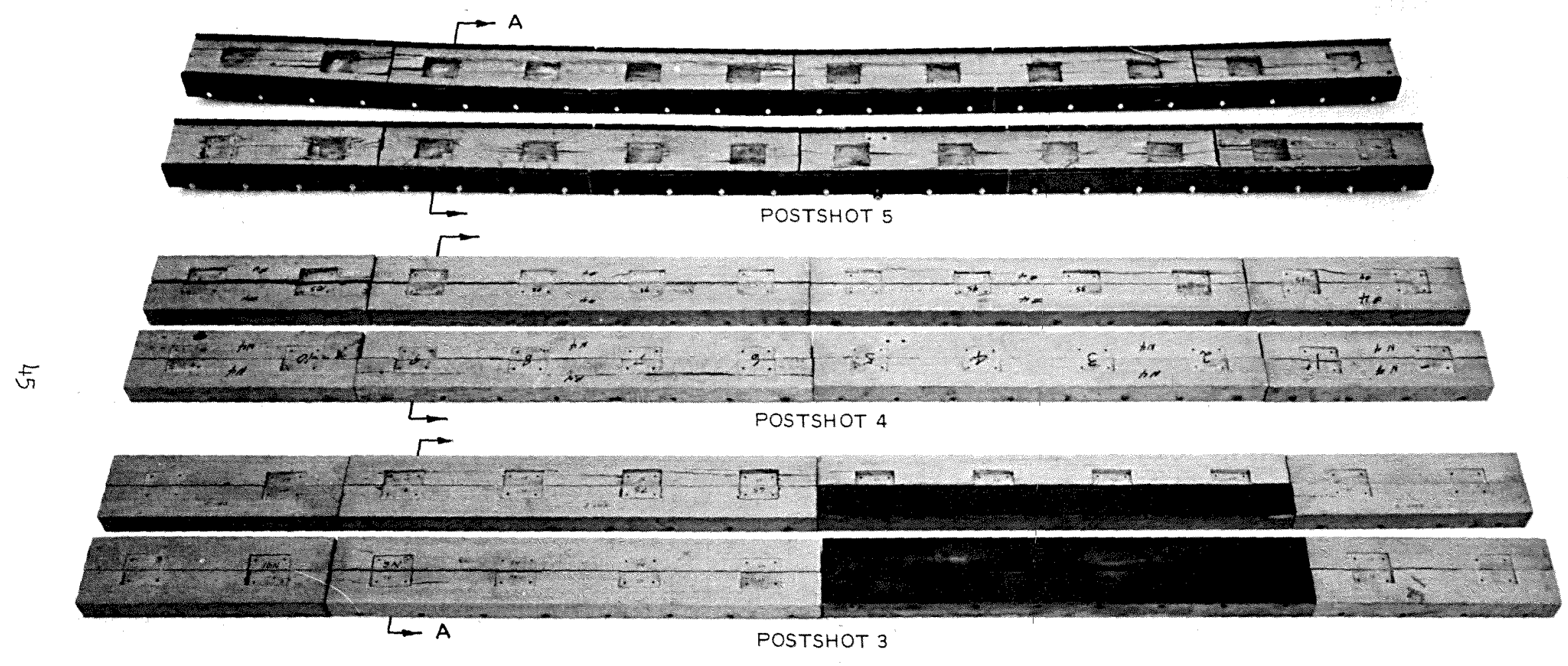

$1500-746$

Figure 3.7 Postshot view of the damaged footings showing the punching damage. Note also the inward bow of the shot 5 footings. 

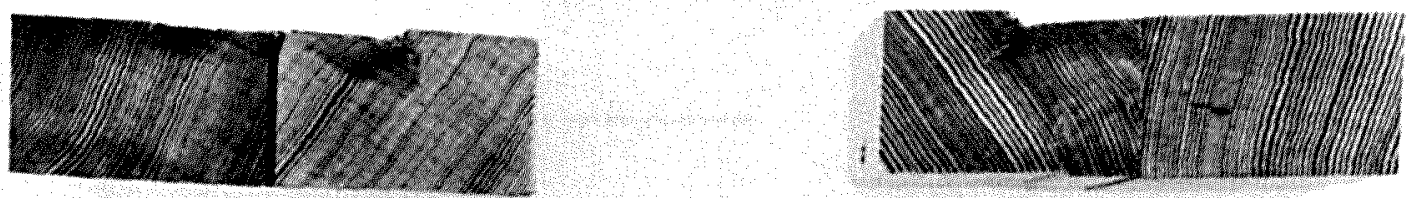

POSTSHOT 3
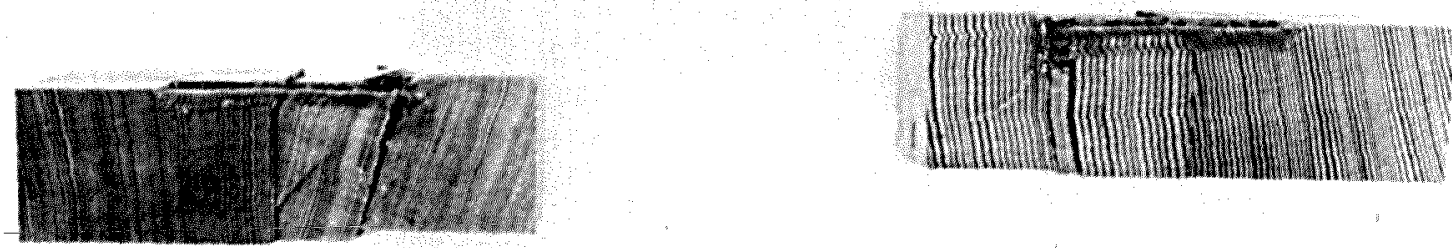

POSTSHOT 4

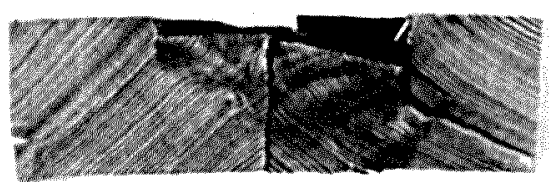

POSTSHOT 5

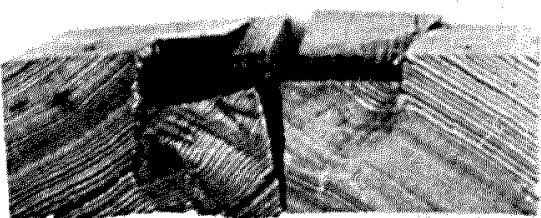

$1500-749$

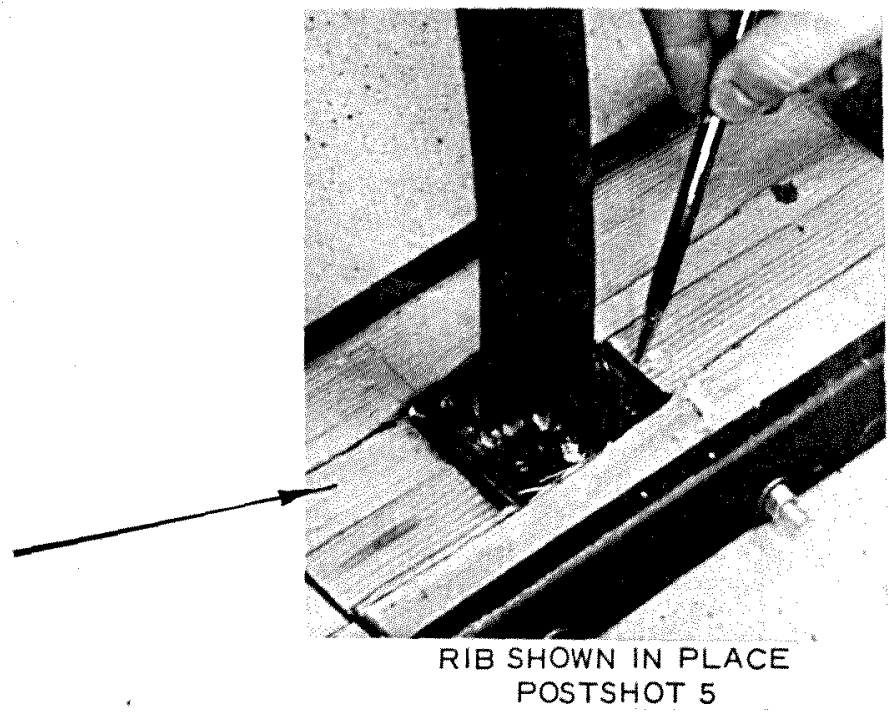

Figure 3.8 Section views of the damage shown in Figure 3.7 to the footings at the section shown (Section AA). 


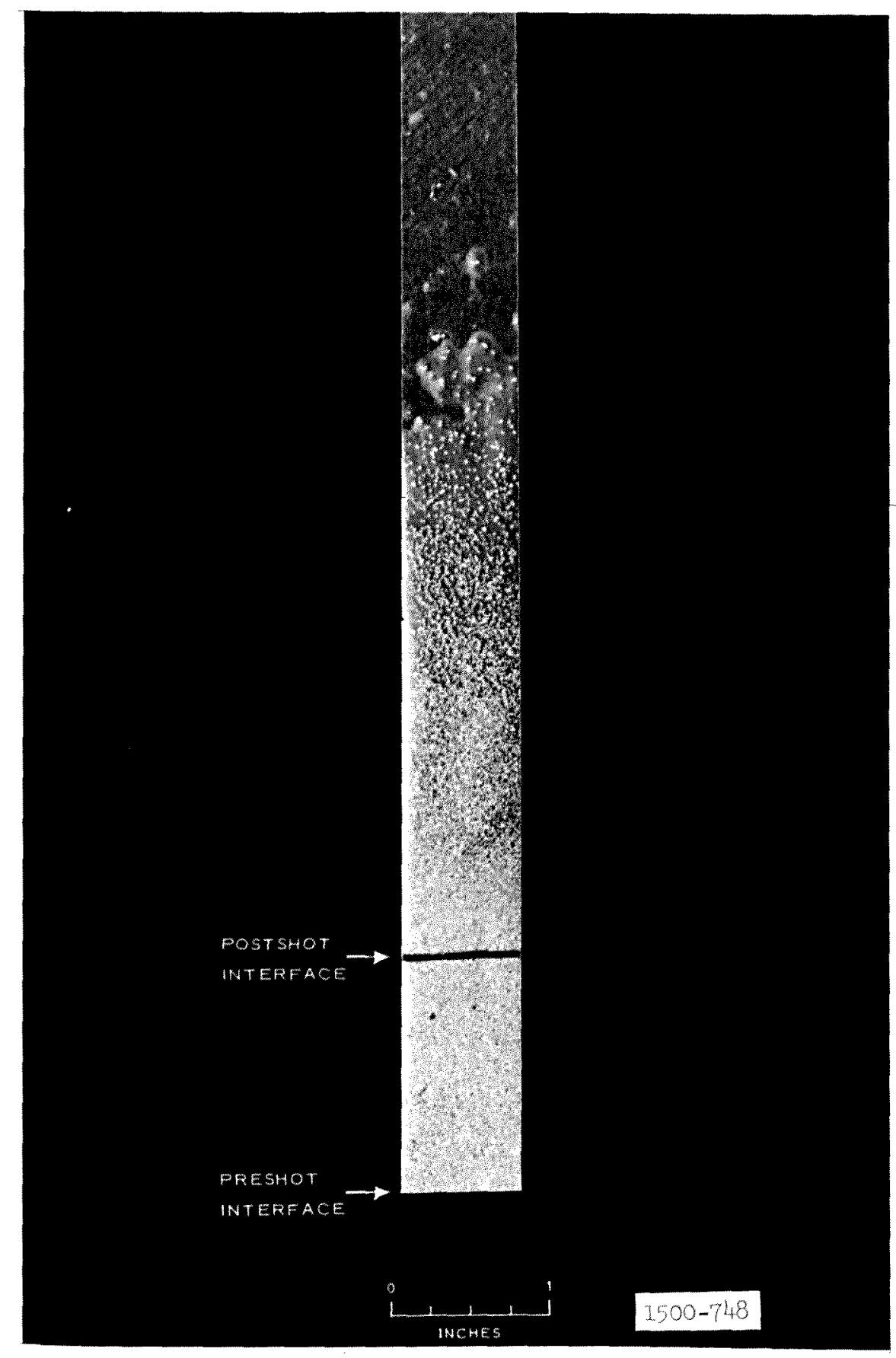

Figure 3.9 Sand spall of the interior floor surface during shot 4. 


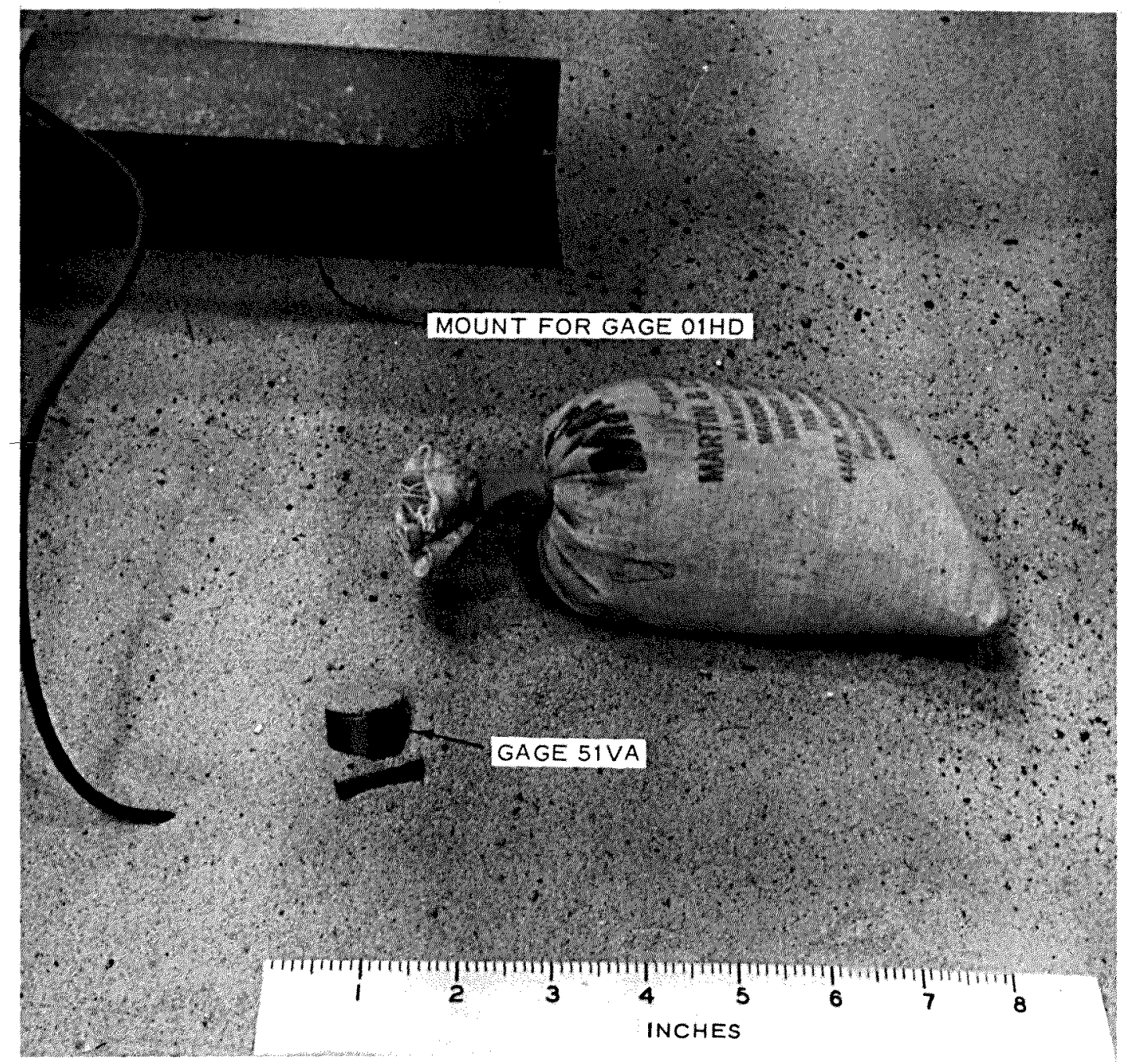

Figure 3.10 Dislocation of Gage 5IVA caused by spalling of the interior floor during shot 5. 


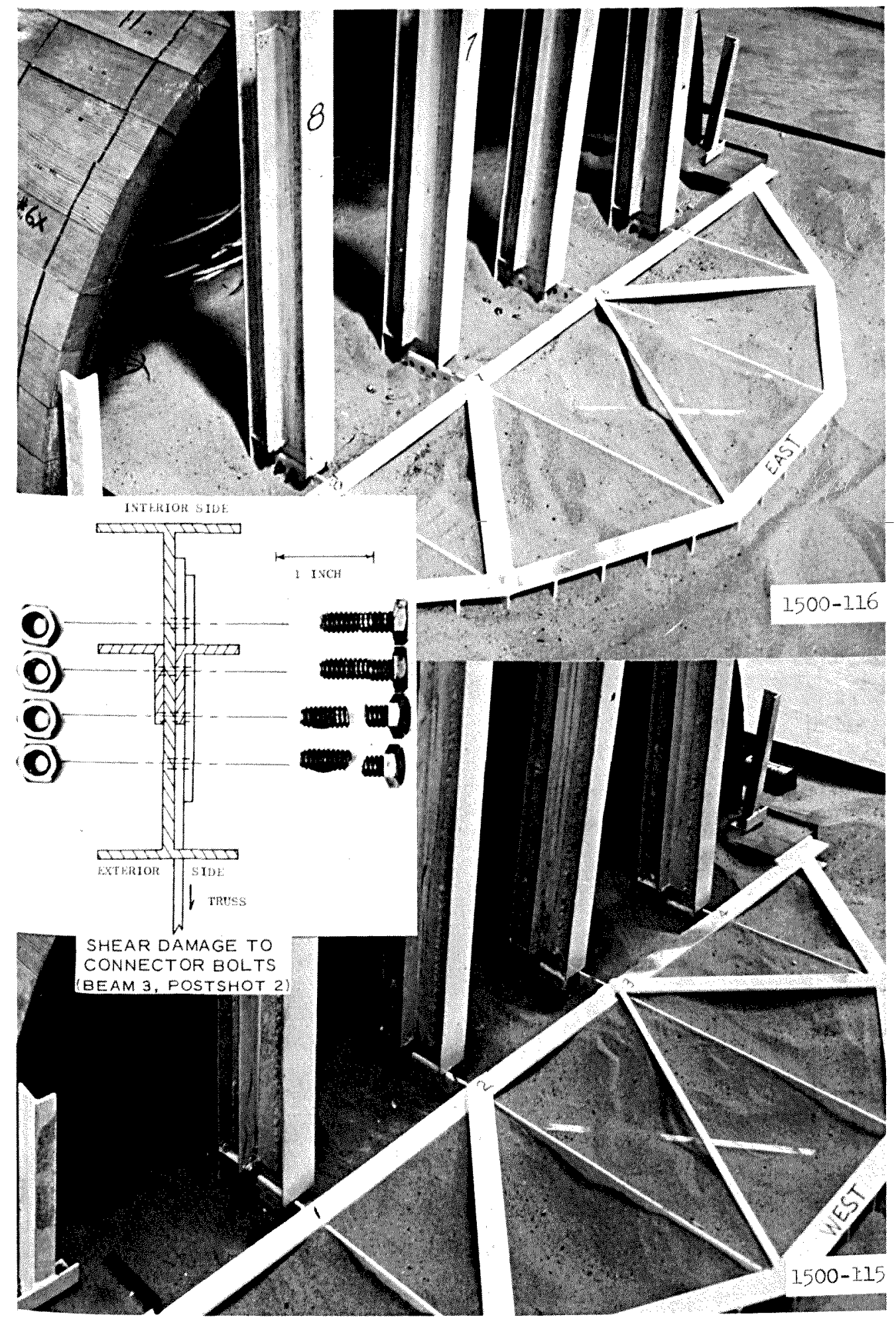

Figure 3.11 Shear damage to connector bolts, main photographs showing the post-pilot-test damage. 


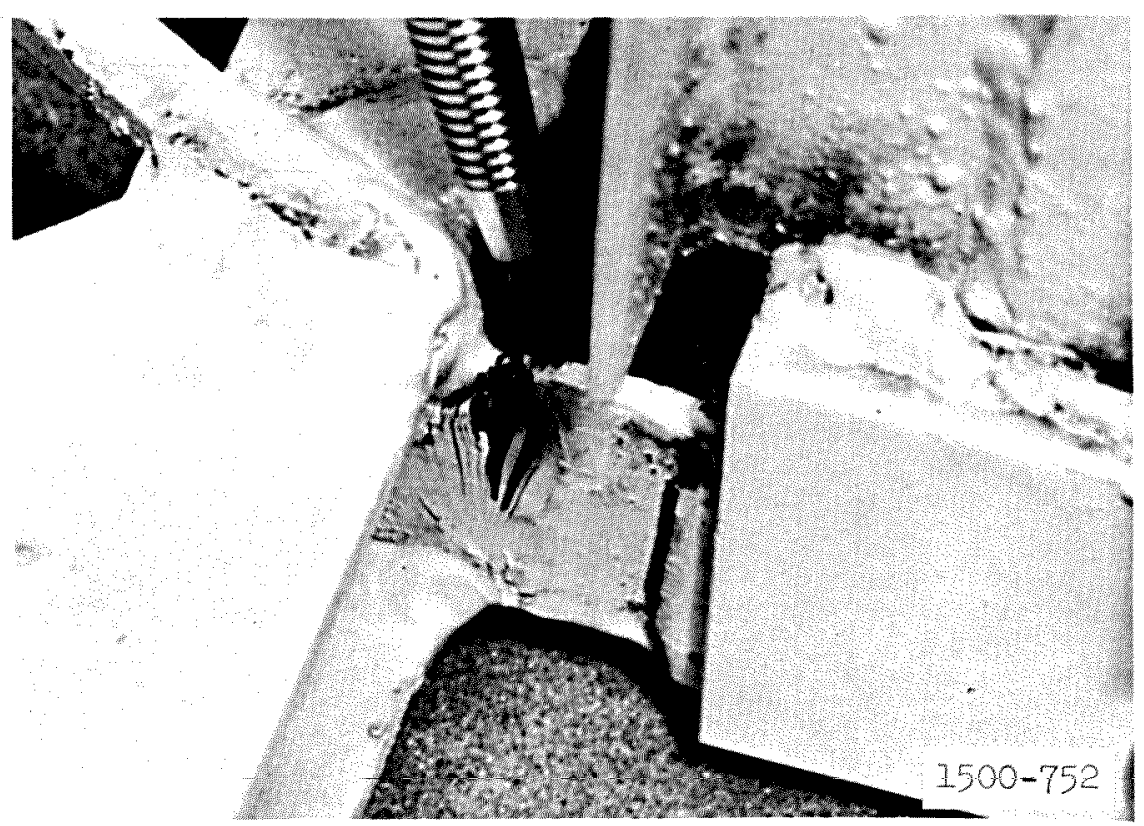

a. Postshot 3. Shear damage to the Beam 2 connector tongue.

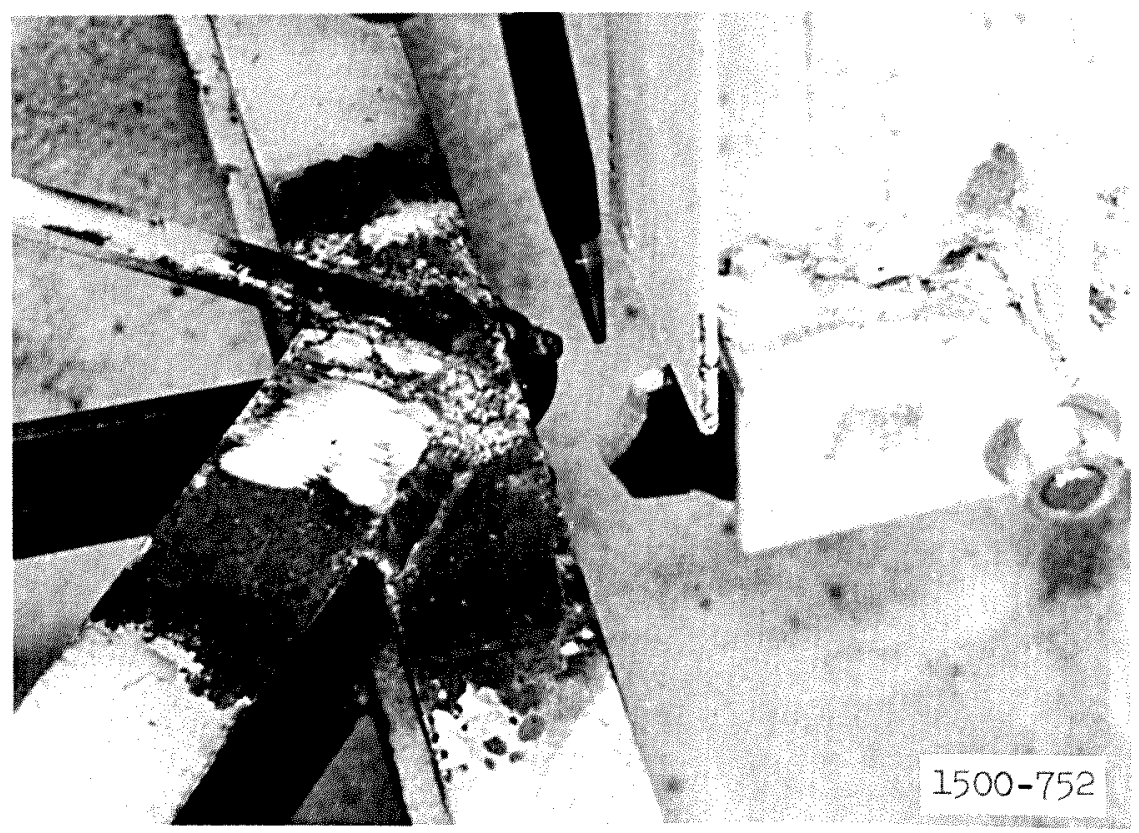

b. Postshot 5. Shear damage to the Beam 2 connector tongue.

Figure 3.12 Damage to the redesigned bulkhead beamtruss connector. 


\section{DISCUSSION OF RESULTS}

\subsection{STRUCTURAL LOADING}

4.1.1 Free Field. The test results and past experience in the LBIG show that the surface overpressure level generally does not affect the initial shape of the soil stress wave or the shape of the acceleration pulse for overpressures in the range of interest. Soil stress peaks are affected by overpressure as is stress wave velocity. Figure 4.1 shows the velocity of the stress wave across the structure as a function of overpressure and also shows the engulfment time. As shown, the velocity increases with overpressure up to about $100 \mathrm{psi}$ and then becomes fairly constant at about $875 \mathrm{ft} / \mathrm{sec}$. The data from shot 2 indicate that the velocity through the previously loaded material was significantly higher than through a virgin specimen at the same overpressure. The presence of the structure does not seem to have a significant effect on the surrounding stress field. However, the limited quantity of data taken and the uncertainty involved in making soil stress measurements under dynamic conditions make this conclusion rather uncertain.

Based on the test data, the ratio of the horizontal to vertical soil stress is about 0.52 and the ratio of the incident soil stress to that reflected off the LBLG bottom about 0.62 . The reflection arxives at the footing level around $17 \mathrm{msec}$ after zero time and is traveling at a higher velocity than the incident stress wave, since it is passing through a prestressed medium. It is no longer a shock, but has a relatively long rise time ( 2 or $3 \mathrm{msec}$ ), and since it is acting mainly on the underside of the structure, hence affecting mainly the footing area, its influence on arch response is not as great as that of the incident loading. Assuming that there is little attenuation of the stress wave as it passes through the first few feet of soil, the incident soil stress acting on the structure is essentially the same as the surface airblast overpressure. Figure 4.2 shows an ideal soil stress shape based on the above discussion and a typical record from shot 3 .

The quality and quantity of the free-field motion data are such that 
no meaningful analysis can be made. The peaks are tabulated in Table A.4 and the integrated velocity and displacement data presented in Appendix $C$. 4.1.2 Radial Interface Loading. The load on the arch in the radial direction was measured with strain gages attached to the inside surface of six of the arch blocks. After calibrating these blocks with a single point loading, they were then placed at various locations at one arch section near the center. Because the exact pressure distribution on these blocks is unknown, there is no way to correlate between the calibrated load and the exact load except in a qualitative manner. To do this, it was assumed that the load distribution on the blocks under dynamic loading was the same during each shot and was the same on each block.

Because of the reflected soil stress wave, there was a reflected peak in the interface loading as well as the incident load level. The incident load is considered to be the significant load. In order to compare the radial load distribution from shot to shot and at various times, all data from a shot were normalized by dividing by the peak value of the transient load measured during a shot. These data are tabulated in Table 4.1 and shown in Figure 4.3. The data generally fall in two sets, one being the two low-pressure shots and the other being the three higher-pressure shots. The low-pressure shots show that the load was somewhat uniformly distributed around the structure except at the footings where the horizontal freedom of the footing at even the low pressures allowed load relief. At the higher pressures, the greater relative inward deflection of the crown caused greater load relief than did the outward deflection of the area 30 degrees above the footing. The relative deflection causing this load relief was observed in the permanently deflected shape of the ribs observed after each shot. Figure 4.4 shows the permanent deformation of Rib 6 measured with the footing ends positioned postshot in their preshot location. The deflected shape generally corresponds to the shape of the load distribution shown in Figure 4.3. In order to determine the general location of the point of greatest outward deflection, each rib was examined after the three highpressure shots. These results are shown in Figure 4.5 and show that the location of this point is between 25 and 30 degrees with some variance along the arch length. These data indicate that the presence of the 
bulkhead did affect to some extent the radial distribution of load on the arch, but probably not in a significant manner. Further evidence of the influence of the bulkheads is shown in Figure 4.6 where it can be observed that the crown deflection was generally less at the bulkheads than in the central area.

\subsection{STRUCTURE MOTION}

Level survey measurements were made to determine the total movement of the structure after shots 3, 4, 5, and the pilot test shot. No measurements of this type were made for shot 2 since it was a repeat loading of the Shot 1 configuration. Figure $4.7 \mathrm{a}$ shows the raw footing survey data and Figure $4.7 \mathrm{~b}$ a plot of dimensionless deflection where

$$
\delta_{\mathrm{d}}=\frac{\left(\delta_{\mathrm{f}}\right)\left(\sigma_{\mathrm{ULT}}\right)}{(\mathrm{w})\left(\mathrm{P}_{\mathrm{sO}}\right)} \quad \begin{aligned}
10 \mathrm{psi} & <\sigma_{\mathrm{ULT}}<30 \mathrm{psi} \\
100 \mathrm{psi} & <\mathrm{P}_{\mathrm{sO}}<200 \mathrm{psi} \\
\mathrm{w} & =5.25 \text { inches }
\end{aligned}
$$

In this expression, $\delta_{f}$ is the measured deflection in inches, $P_{\text {so }}$ is the airblast overpressure in pounds per square inch, $w$ is the footing width in inches, and $\sigma_{\text {ULT }}$ is the ultimate static plate-bearing pressure in pounds per square inch taken from Figure 2.3 and assumed to be 27, 20, 23, and 23 psi for shots 3, 4, and 5 and the pilot test, respectively. A polynomial fit to the deflection data produces the following expression for deflection:

$$
\delta_{d}=\left(1.79 \times 10^{-2}\right)+\left(1.67 \times 10^{-3}\right) \mathrm{I}_{\mathrm{f}} \quad 0<\mathrm{I}_{\mathrm{f}}<44 \text { inches }
$$

where $L_{f}$ is the distance along the footing from one end in inches.

In Figure 4.6 the surveyed crown deflection relative to the footing deflection is shown with the average of the north and south footing deflections at a location being assumed as the footing deflection. Both the footing and the crown deflection data show more scatter at the west end, especially in the case of shot 4. This is thought to be due to the 
presence of the free-field instrumentation cables which generally were run out the west end of the structure to the free-field gages. The difference in relative crown deflection between Shots 4 and 5, and between shot 3 and the pilot test indicates that there was little rib deformation at the lower pressure with most of the motion being rigid-body motion, whereas at the higher pressures rib deformation became a major factor in total crown deflection. The rib strain data as well as the data in Figures 4.4 and 4.5 support this supposition.

The measured time-deflection histories of the footings near the vertical centerline of the structure for shots 3, 4, and 5 are shown in Figures $4.8,4.9$, and 4.10, respectively. These data were calculated using the deflection gage data from the rig shown in Figure A.4. The deflection components are shown in Appendix $C$. These data show that there was an initial displacement radially outward corresponding to the arrival of the loading at the crown region of the structure. This was followed by a downward deflection as engulfment occurred during which time the outward motion reversed to become an inward displacement. Final downward displacement occurred in a jerky fashion because of the arrival of the reflected stress wave. The final position of the footing as measured agrees with those data in Figure 4.7 and agrees with observed final shape of the footings as shown in Figure 3.7 , i.e. bowed inward.

Acceleration measurements were made at the center of the footing and at one end of the footing to determine what differences in motion occurred at these locations, i.e. to determine what influence the bulkheads had in altering the footing acceleration. The peak accelerations and velocities resulting at these two locations as a function of overpressure are shown in Figures 4.11 and 4.12, respectively. In both cases, the quantities measured at the end of the footing were lower in magnitude than those at the center locations. A typical acceleration record and the velocity- and displacement-time histories resulting from single and double integration of these data are shown in Figure 4.13 .

4.3 STRUCTURAL RESPONSE

Whenever a structural element undergoes a combination of thrust and 
moment, an interaction of these two quantities occurs which tends to either move the section nearer to or away from its ultimate load-carrying ability. In the case of the arch being considered, the element being loaded was a tee-section rib having dimensions as shown in Figure 4.14a. The steel had a stress-strain curve as shown in Figure 4.14b. The test results indicate that the ribs exceeded their elastic limit during some of the tests. To simplify the analysis of these data, an elastic-plastic idealization (Figure 4.14b) was made. Yield stress at 0.1 percent offset was 59,930 psi and yield strain was 0.23 percent. Based on this idealization of the stressstrain curve, the rib strain data were converted into moment and thrust. Moments producing compression in the outer fibers are considered positive and thrusts producing fiber compression are considered positive. All. moment- and thrust-time histories are shown in Appendix $\mathrm{C}$.

The general shape of the strain data, hence the moment and tirust data, followed the free-field stress wave shape. Thus, there was an initial or transient peak in the data, generally occurring about 5 to $10 \mathrm{msec}$ after detonation, and a reflected peak occurring 15 to $20 \mathrm{msec}$ after detonation. The thrust and moment data are tabulated in Tables 4.2 and 4.3 and the quantities tabulated are defined in Figure 4.15. The shape of these data also reflect the interface loading as described in Section 4.1. Figure 4.16 shows typical data for a section remaining elastic and for a section that has strains exceeding the elastic limit.

The peak transient thrust data are plotted in Figure 4.17 and show considerable scatter. However, data analysis indicates that the thrust throughout the arch ring is generally uniform with a slight tendency for the thrust to increase as the arch crown is approached. Regression analysis of these data gives the following equation for the peak transient thrust in the arch section in terms of peak overpressure $P_{\text {so }}$ and angle above the footing $\theta$.

$$
\begin{gathered}
\mathrm{N}_{\mathrm{p}}=\left(26.2+11.1 \mathrm{P}_{\text {so }}+1.98 \theta\right) \mathrm{lb} / \mathrm{in} \\
0<\theta<75 \text { degrees } \\
30<\mathrm{P}_{\text {SO }}<200 \mathrm{psi}
\end{gathered}
$$


The lines shown in Figure 4.17 are based on this equation.

The moment data show appreciable scatter. During the first two shots it appears that the loading was not great enough to fully flex the structure; hence, even the sign of the data exhibited scatter. As the load increased, the moments up to 45 degrees were generally negative, which corresponds to the permanent deflection measurements. Because of the scatter in these data, no detailed data analysis was attempted.

4.4 INTERIOR ENVIRONMENT

Two quantities were measured inside the structure, interior pressure and floor acceleration. The peak pressure appears to be directly related to the decrease in interior volume caused by the punching of the footings since no breach occurred which would allow the airblast overpressure to enter the inside of the structure. Peak pressure versus footing punch from the survey data is shown in Figure 4.18 where the footing data are those extrapolated to the Rib 5 location on the north and south footings. Using the equation given, assuming the straight line fit of these data and the normalized data in Figure $4.7 \mathrm{~b}$ as expressed by Equation 4.2 , the interior pressure can be presented as

$$
\mathrm{P}_{I N}=\left[\frac{3.58(\mathrm{w})\left(\mathrm{P}_{\mathrm{SO}}\right)}{100\left(\sigma_{U L T}\right)}\left(1.79+0.167 \mathrm{I}_{\mathrm{f}}\right)-3.11\right] \mathrm{psi}
$$

The acceleration measured on the interior floor was characterized by two sharp spikes (Figure 4.19). The first and largest spike was caused by engulfment and punching of the footings and the second spike by the reflection off the base of the LBLG. Double integration of the data gave poor results as far as displacement was concerned, but gave reasonable velocity data. These data are shown as time histories in Appendix $\mathrm{C}$ and the peak data are shown in Figure 4.20. 
TABIE 4.I RATIO OF RADIAL LOAD TO PEAK TRANSIENT RADIAL LOAD NR - not recovered.

\begin{tabular}{llllll} 
Angle & \multicolumn{4}{c}{ Load Ratio at } \\
\cline { 2 - 5 } $\begin{array}{l}\text { Above } \\
\text { Footing }\end{array}$ & $\begin{array}{l}\text { Incident } \\
\text { Peak }\end{array}$ & $10 \mathrm{msec}$ & $20 \mathrm{msec}$ & $30 \mathrm{msec}$ & $40 \mathrm{msec}$ \\
& & & & & \\
\hline
\end{tabular}

\section{degrees}

Shot I:

\begin{tabular}{rccccc}
8 & \multicolumn{5}{c}{ InsignificantIy small } \\
24 & 0.91 & 0.79 & 0.71 & 0.21 & 0.23 \\
45 & 0.95 & 0.74 & 0.90 & 0.82 & 0.74 \\
45 & 0.99 & 0.80 & 0.98 & 0.84 & 0.75 \\
67 & 0.67 & 0.49 & 0.59 & 0.28 & 0.15 \\
83 & 1.00 & 0.81 & 0.98 & 0.87 & 0.71
\end{tabular}

Shot 2:

$\begin{array}{rlllll}8 & 0.25 & 0.13 & 0.20 & 0.06 & 0.03 \\ 24 & 0.91 & 0.81 & 0.72 & 0.22 & 0.06 \\ 45 & 0.93 & 0.82 & 0.93 & 0.56 & 0.44 \\ 45 & 1.00 & 0.91 & 0.96 & 0.62 & 0.50 \\ 67 & 0.75 & 0.66 & 0.82 & 0.56 & 0.54 \\ 83 & 0.81 & 0.79 & 0.85 & 0.60 & 0.66\end{array}$

Shot 3:

$\begin{array}{cc}8 & 0.36 \\ 24 & 1.00 \\ 45 & \text { NR } \\ 45 & 0.65 \\ 67 & \text { NR } \\ 83 & 0.52\end{array}$

$\begin{array}{cc}0.34 & 0.17 \\ 1.00 & 0.83 \\ \text { NR } & \text { NR } \\ 0.61 & 0.51 \\ \text { NR } & \text { NR } \\ 0.51 & 0.43\end{array}$

0.03

0.09

0.46

NR

0.46

0.30

NR

NR

0.33

0.32

NR

0.34

Shot 4:

$\begin{array}{rl}8 & 0.36 \\ 24 & 1.00 \\ 45 & 0.51 \\ 45 & 0.75 \\ 67 & 0.61 \\ 83 & 0.60\end{array}$

0.34

0.25

0.89

1.28

0.41

0.59

0.68

0.70

0.55

0.69

0.56

0.57

$-0.08$

$-0.02$

0.49

0.44

0.26

0.28

0.19

0.23

0.39

0.42

0.32

0.33

Shot 5:

\begin{tabular}{rccccc}
8 & 0.23 & 0.21 & 0.25 & 0.09 & 0.16 \\
24 & 0.86 & 0.86 & 0.69 & 0.27 & 0.41 \\
45 & 1.00 & 0.96 & 0.91 & 0.31 & 0.51 \\
45 & NR & NR & NR & NR & NR \\
67 & 0.52 & 0.46 & 0.54 & 0.22 & 0.31 \\
83 & 0.60 & 0.60 & 0.46 & 0.15 & 0.23 \\
\hline
\end{tabular}


TABLE 4.2 TABULATLD THRIST DATA

Symbols used are defined in the lotation which precedes the text and are illustrated in pigure 4.15 .

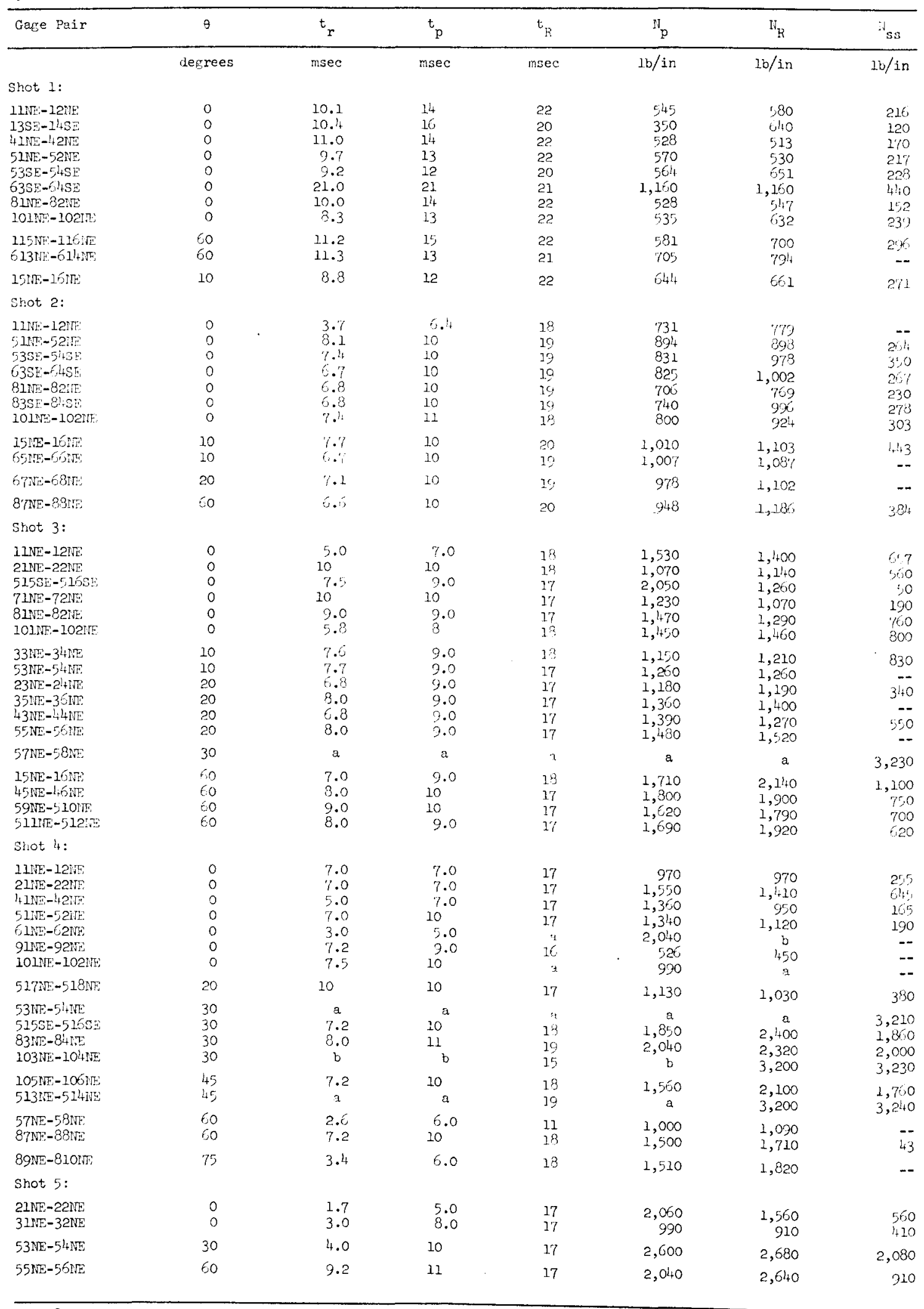

\footnotetext{
a Indeteminate.

Steady rise up to $\mathrm{r}_{\mathrm{R}}$.
} 
TABLE 1.3 TABULATED MMTIHT DATA

symbols used re defined in the Jotation widei: preceles the text and are illustrated in firure $t .1$,

\begin{tabular}{|c|c|c|c|c|c|c|c|}
\hline Gage Pair & 9 & $t_{r}$ & $t_{p}$ & $t_{R}$ & $M_{p}$ & $i_{3}$ & $M_{s s}$ \\
\hline & derrees & msec & msec & msec & $i n-1) / n$ & $i n-1 b / i n$ & $i r-1 b / i n$ \\
\hline \multicolumn{8}{|l|}{ Shot I: } \\
\hline $\begin{array}{l}11 \mathrm{NE}-12 \mathrm{NE} \\
13 \mathrm{SE}-114 \mathrm{SE} \\
41 \mathrm{NE}-42 \mathrm{NE} \\
51 \mathrm{NE}-52 \mathrm{NE} \\
53 \mathrm{SE}-54 \mathrm{SE} \\
63 \mathrm{SE}-643 \mathrm{E} \\
81 \mathrm{NE}-82 \mathrm{NE} \\
101 \mathrm{NE}-102 \mathrm{NE}\end{array}$ & $\begin{array}{l}0 \\
0 \\
0 \\
0 \\
0 \\
0 \\
0 \\
0\end{array}$ & $\begin{array}{r}6.1 \\
2.8 \\
6.3 \\
2.8 \\
2.8 \\
13.5 \\
5.7 \\
2.8\end{array}$ & $\begin{array}{r}9.0 \\
5.0 \\
9.0 \\
6.0 \\
6.0 \\
15.0 \\
8.0 \\
5.0\end{array}$ & $\begin{array}{l}20 \\
23 \\
22 \\
2 ! 4 \\
18 \\
29 \\
23 \\
1.8\end{array}$ & $\begin{array}{l}+1+0.7 \\
-137 \\
+92.5 \\
-72.5 \\
-37.3 \\
-30.5 \\
+104 \\
-20.5\end{array}$ & $\begin{array}{r}+22.9 \\
-4.3 \\
+83 . \% \\
+50.5 \\
-6.0 .3 \\
-83.0 \\
+89.9 \\
-15.8\end{array}$ & $\begin{array}{r}+1 . .2 \\
-38.0 \\
-3.8 \\
-28.1 \\
-1.5 \\
-27.0 \\
-9.1 \\
-0.7\end{array}$ \\
\hline $15 \mathrm{NE}-16 \mathrm{JE}$ & 10 & $1 / t$ & 18 & 24 & $-16 \%$ & $-16 ?$ & -136 \\
\hline $\begin{array}{l}115 \mathrm{NE}-116 \mathrm{me} \\
613 \mathrm{NF}-6,11^{4}+1 \mathrm{~N}\end{array}$ & 60 & $\begin{array}{l}9.2 \\
\% \cdot 6\end{array}$ & $\begin{array}{l}15 \\
13\end{array}$ & $\begin{array}{l}21 \\
21\end{array}$ & $\begin{array}{l}+104 \\
-1+17\end{array}$ & $\begin{array}{l}+13 \\
-43.2\end{array}$ & $+23 ! !$ \\
\hline \multicolumn{8}{|l|}{ Shot 2: } \\
\hline 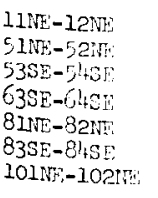 & $\begin{array}{l}0 \\
0 \\
0 \\
0 \\
0 \\
0 \\
0\end{array}$ & $\begin{array}{l}5.2 \\
6.2 \\
2.3 \\
5.9 \\
.1 \\
7.5 \\
2\end{array}$ & $\begin{array}{c}11 \\
8.0 \\
5.0 \\
7.0 \\
7.0 \\
3.0 \\
9\end{array}$ & $\begin{array}{l}19 \\
13 \\
19 \\
17 \\
13 \\
17 \\
19\end{array}$ & $\begin{array}{r}+19.7 \\
+11.1 \\
-90.2 \\
+116 \\
+100 \\
+119 \\
2\end{array}$ & $\begin{array}{r}+9.2 \\
1 \cdots .1 \\
-99.7 \\
+34.0 \\
+1 \% .8 \\
+73.0 \\
-11+0\end{array}$ & $\begin{array}{r}-- \\
-33.14 \\
-96.1 \\
-5.0 \\
-5.0 \\
-9.0 \\
-89.0\end{array}$ \\
\hline $\begin{array}{l}15 \mathrm{NL}-16 \mathrm{~m} \\
65 \mathrm{NW}-66 \mathrm{~N}\end{array}$ & $\begin{array}{l}10 \\
10\end{array}$ & 8.1 & $13^{0}$ & $\begin{array}{r}b \\
20\end{array}$ & $\begin{array}{l}-1.23 \\
-2.1\end{array}$ & $\begin{array}{r}b \\
-311\end{array}$ & -92. \\
\hline $67 \mathrm{NE}-68 \mathrm{NE}$ & 20 & $\mathrm{~b}$ & $b$ & 25 & b & -.00 & -754 \\
\hline 87NE-89N: & 60 & $\mathrm{~b}$ & b. & br & ò & 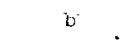 & -12 \\
\hline \multicolumn{8}{|l|}{ Shot 3: } \\
\hline $\begin{array}{l}11 \mathrm{NE}-12 \mathrm{NE} \\
21 \mathrm{NE}-22 \mathrm{NJ} \\
515 \mathrm{SE}-516 \mathrm{SH} \\
71 \mathrm{NE}-721 \mathrm{~W} \\
81 \mathrm{NE}-82 \mathrm{NE} \\
101 \mathrm{NE}-102 \mathrm{NE}\end{array}$ & $\begin{array}{l}0 \\
0 \\
0 \\
0 \\
0 \\
0\end{array}$ & $\begin{array}{l}\mathrm{b} \\
10^{2} \\
2.0 \\
0.0 \\
5.0 \\
1.0\end{array}$ & $\begin{array}{c}16 \\
10^{b} \\
4.0 \\
10 \\
5.0 \\
3.0\end{array}$ & $\begin{array}{c}b \\
b \\
b \\
b \\
b \\
b \\
1: 4\end{array}$ & $\begin{array}{r}b \\
237 \\
-137 \\
-4 ? \\
-1110 \\
-119\end{array}$ & $\begin{array}{r}\mathrm{b} \\
\mathrm{b} \\
-123 \\
\mathrm{~b} \\
\mathrm{~b} \\
-2\end{array}$ & $\begin{array}{r}-199 \\
51 \\
-38 \\
-82 \\
-63 \\
-1: 0\end{array}$ \\
\hline $\begin{array}{l}33 \mathrm{NE}-34 \mathrm{NE} \\
53 \mathrm{NE}-5: \mathrm{NE}\end{array}$ & $\begin{array}{l}10 \\
10\end{array}$ & $\begin{array}{l}1.5 \\
1.5\end{array}$ & $\begin{array}{l}7.0 \\
3.0\end{array}$ & $\begin{array}{l}15 \\
13\end{array}$ & $\begin{array}{l}-2 ! 7 \\
-113\end{array}$ & $\begin{array}{r}-6 a \\
-282\end{array}$ & -9 \\
\hline $\begin{array}{l}23 \mathrm{NE}-21+\mathrm{NE} \\
35 \mathrm{WE}-36 \mathrm{NE} \\
43 \mathrm{NE}-4+4 \mathrm{NW} \\
55 \mathrm{NE}-66 \mathrm{NE}\end{array}$ & $\begin{array}{l}20 \\
20 \\
20 \\
20\end{array}$ & $\begin{array}{l}2.0 \\
0.3 \\
1.0 \\
1.2\end{array}$ & $\begin{array}{l}3.0 \\
3.0 \\
3.0 \\
3.0\end{array}$ & $\begin{array}{l}17 \\
17 \\
19 \\
17\end{array}$ & $\begin{array}{l}-1 \% \overline{1} \\
-200 \\
-220 \\
-1 \%\end{array}$ & $\begin{array}{l}-1,63 \\
-270 \\
-1,02 \\
-146\end{array}$ & $\begin{array}{r}-- \\
-2,140 \\
--\end{array}$ \\
\hline $57 \mathrm{NE}-58 \mathrm{NE}$ & 30 & $1+.2$ & 5.0 & $\mathrm{~b}$ & -102 & $b$ & 0 \\
\hline $\begin{array}{l}15 \mathrm{NE}-16 \mathrm{NE} \\
45 \mathrm{NE}-46 \mathrm{IF} \\
59 \mathrm{NE}-510 \mathrm{NE} \\
511 \mathrm{NH}-512 \mathrm{IN}\end{array}$ & $\begin{array}{l}60 \\
60 \\
50\end{array}$ & $\begin{array}{c}b \\
55 \\
\vdots .7 \\
a\end{array}$ & $\begin{array}{c}24 \\
0.0 \\
0.0 \\
7\end{array}$ & $\begin{array}{l}2+ \\
21 \\
20 \\
20\end{array}$ & $\begin{array}{r}b \\
-12 y \\
-15 \\
a\end{array}$ & $\begin{array}{l}-17 i \\
-22 \% \\
-175 \\
-20\end{array}$ & $\begin{array}{l}-217 \\
-222 \\
-162 \\
-11+2\end{array}$ \\
\hline \multicolumn{8}{|l|}{ Shot 4: } \\
\hline $\begin{array}{l}\text { 11NE-12NE } \\
21 N E-22 N E \\
41 N E-42 N \mathrm{NE} \\
\text { 51NE-52NE } \\
\text { 61NE-62NE } \\
91 \mathrm{NE}-92 \mathrm{NE} \\
\text { 101NE-102NE }\end{array}$ & $\begin{array}{l}0 \\
0 \\
0 \\
0 \\
0 \\
0 \\
0\end{array}$ & $\begin{array}{l}5.0 \\
5.0 \\
5.6 \\
4.0 \\
6.1 \\
2.9 \\
1.5\end{array}$ & $\begin{array}{l}5.0 \\
.0 \\
7.0 \\
1.0 \\
9.0 \\
.0 \\
.0\end{array}$ & $\begin{array}{r}32 \\
3^{?}+ \\
33 \\
33 \\
b \\
b \\
b\end{array}$ & $\begin{array}{r}-90 \\
-122 \\
-1 \% 9 \\
-120 \\
-99 \\
-30 \\
4\end{array}$ & $\begin{array}{r}-74 \\
-67 \\
214 \\
-20 \\
b \\
-181.4 \\
a\end{array}$ & $\begin{array}{c}-130 \\
-3.0 \\
29 \\
3.0 \\
-- \\
-- \\
--\end{array}$ \\
\hline $517 \mathrm{NE}-518 \mathrm{NE}$ & 20 & 4.0 & 4.0 & $\mathrm{~L}_{i}^{\prime}$ & -135 & 81 & 42 \\
\hline $\begin{array}{l}53 \mathrm{NE}-54 \mathrm{Ni} \\
515 \mathrm{SE}-5 \mathrm{JSE} \\
83 \mathrm{NE}-8 \mathrm{NTE} \\
103 \mathrm{NE}-104 \mathrm{TE}\end{array}$ & $\begin{array}{l}30 \\
30 \\
30 \\
30\end{array}$ & $\begin{array}{c}2.7 \\
0 \\
2 \\
5.0\end{array}$ & $\begin{array}{c}5.0 \\
7 \\
1 \\
5.0\end{array}$ & $\begin{array}{l}27 \\
16 \\
15 \\
18\end{array}$ & $\begin{array}{r}-112 \\
4 \\
a \\
-70\end{array}$ & $\begin{array}{r}-45 \\
-1,0 \\
-1,68 \\
-1+2\end{array}$ & $\begin{array}{r}1.0 \\
-630 \\
-61+ \\
0\end{array}$ \\
\hline $\begin{array}{l}1051 \mathrm{~F}-10 \mathrm{NE} \\
513 \mathrm{SE}-51 ! \mathrm{EF}\end{array}$ & $\begin{array}{l}45 \\
45\end{array}$ & $\begin{array}{c}b \\
\therefore .0\end{array}$ & $\begin{array}{l}\mathrm{b} \\
5.0\end{array}$ & $\begin{array}{r}b \\
18\end{array}$ & $\begin{array}{r}b \\
-105\end{array}$ & $\begin{array}{l}b \\
-2.0\end{array}$ & $\begin{array}{r}-538 \\
0\end{array}$ \\
\hline $\begin{array}{l}5 \mathrm{FNE}-58 \mathrm{NE} \\
87 \mathrm{NE}-98 \mathrm{NE}\end{array}$ & 60 & $\begin{array}{l}3.0 \\
6.0\end{array}$ & $\begin{array}{l}5.0 \\
9.0\end{array}$ & $\frac{1.2}{33}$ & $\begin{array}{l}-25 \\
-6\end{array}$ & $\begin{array}{l}-69 \\
-86\end{array}$ & $-\overline{109}$ \\
\hline \multicolumn{8}{|l|}{ Shot $5:$} \\
\hline $\begin{array}{l}\text { 21NE--22NE: } \\
\text { 31NE-32IVE: }\end{array}$ & $\begin{array}{l}0 \\
0\end{array}$ & $\begin{array}{c}a \\
3.0\end{array}$ & 9.0 & $\begin{array}{l}17 \\
17\end{array}$ & $\begin{array}{r}a \\
-1^{1}+2\end{array}$ & $\begin{array}{l}185 \\
-47\end{array}$ & $\begin{array}{r}251 \\
73\end{array}$ \\
\hline $53 \mathrm{NEE}-54 \mathrm{NE}$ & 30 & $2.1 ;$ & 9.0 & 15 & $-44 i 1$ & -490 & -507 \\
\hline $55 \mathrm{NE}-56 \mathrm{NE}$ & 60 & $\mathrm{~b}$ & 7 & 19 & $\mathrm{~b}$ & $-1+6$ & -82 \\
\hline
\end{tabular}




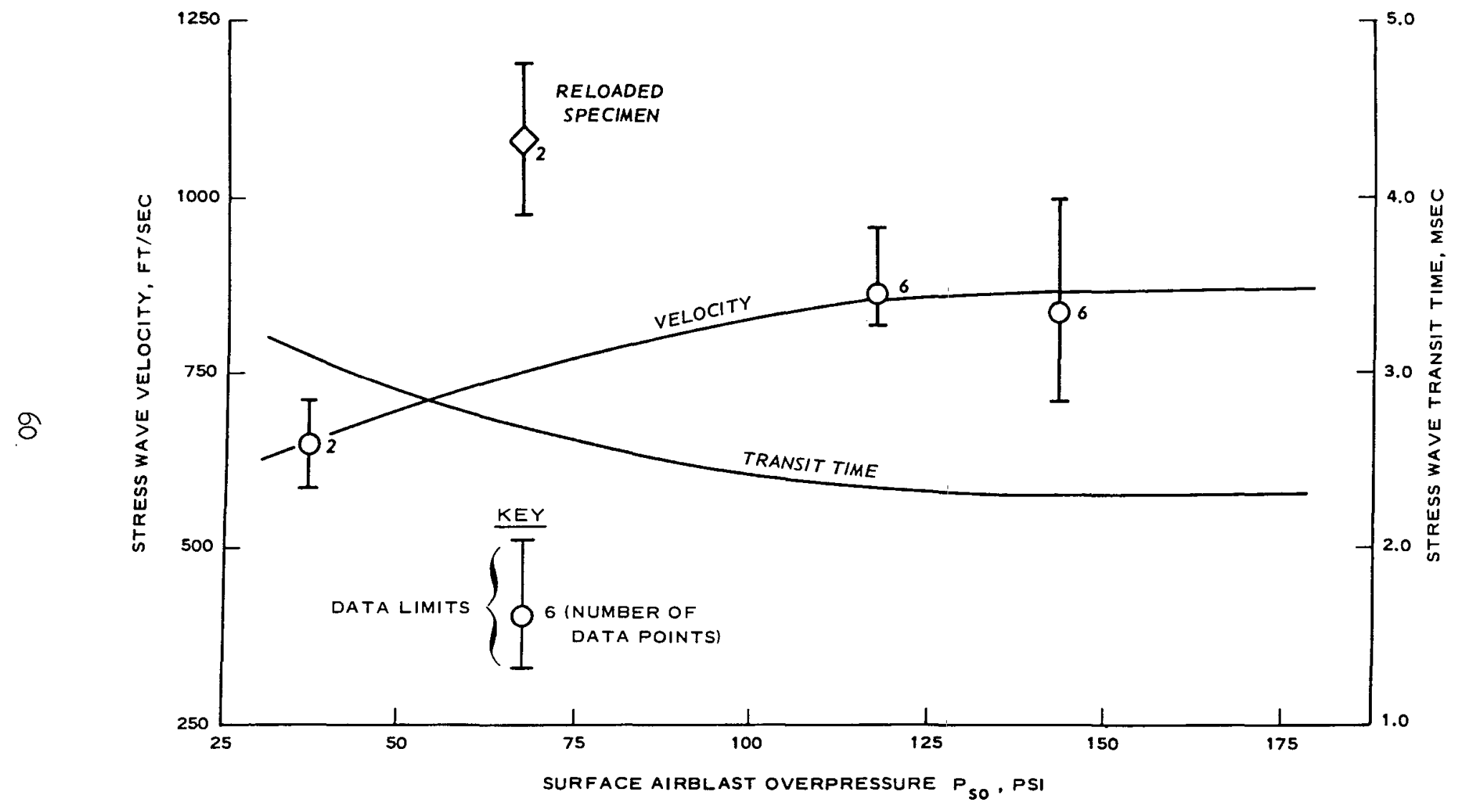

Figure 4.1 Soil stress wave velocity. 


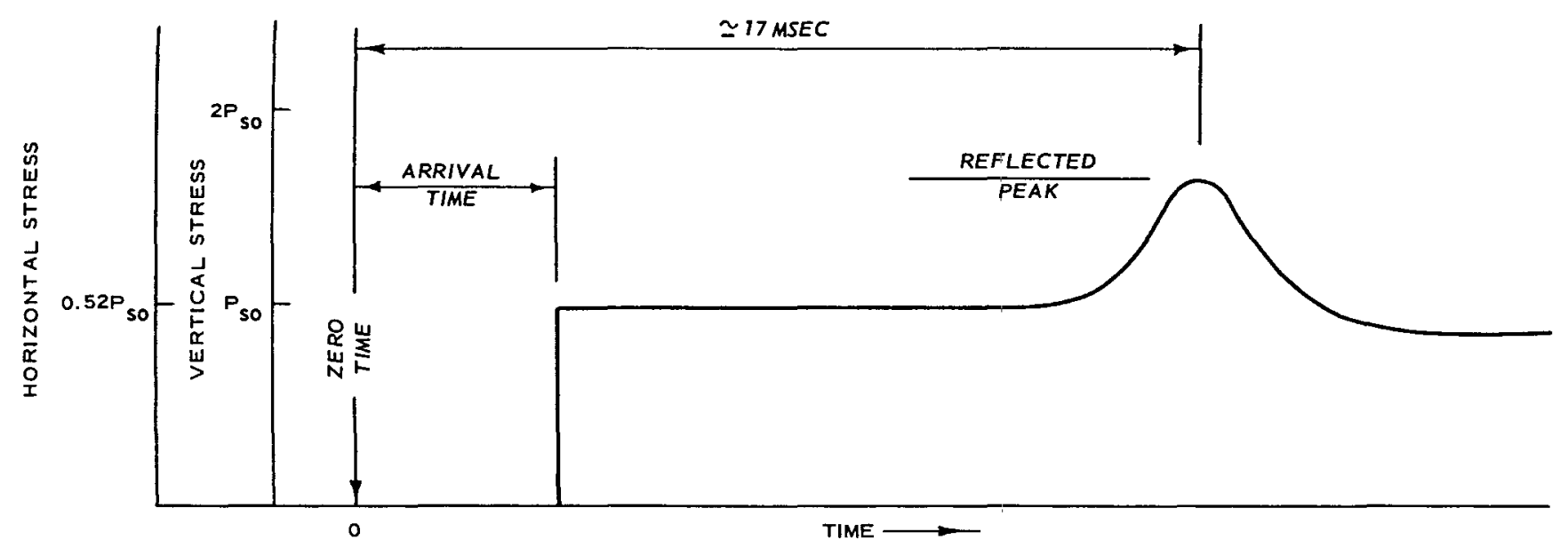

a. IDEALIZED FREE-FIELD STRESS TIME HISTORY

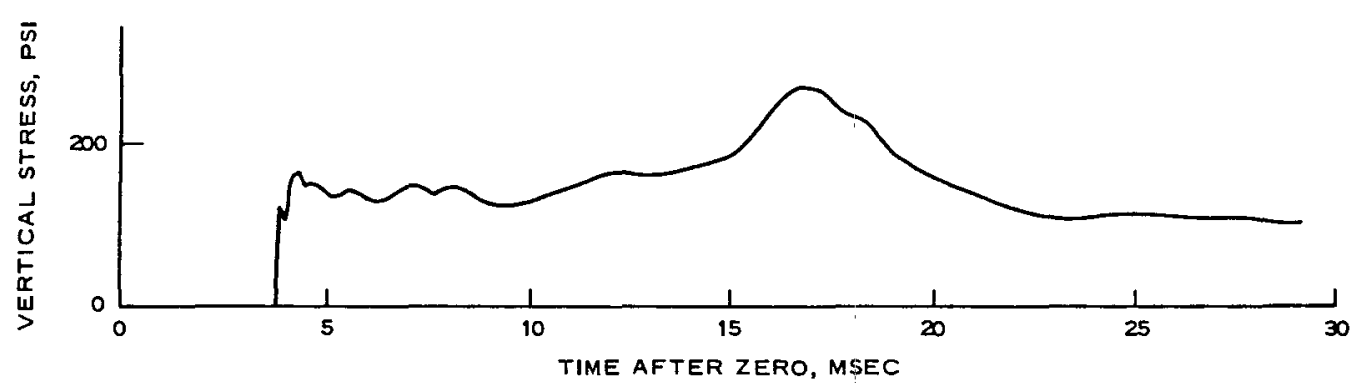

b. TYPICAL FREE-FIELD STRESS TIME HISTORY, SHOT 3 GAGE SS4

Figure 4.2 Idealized and typical free-field soil stress data. 


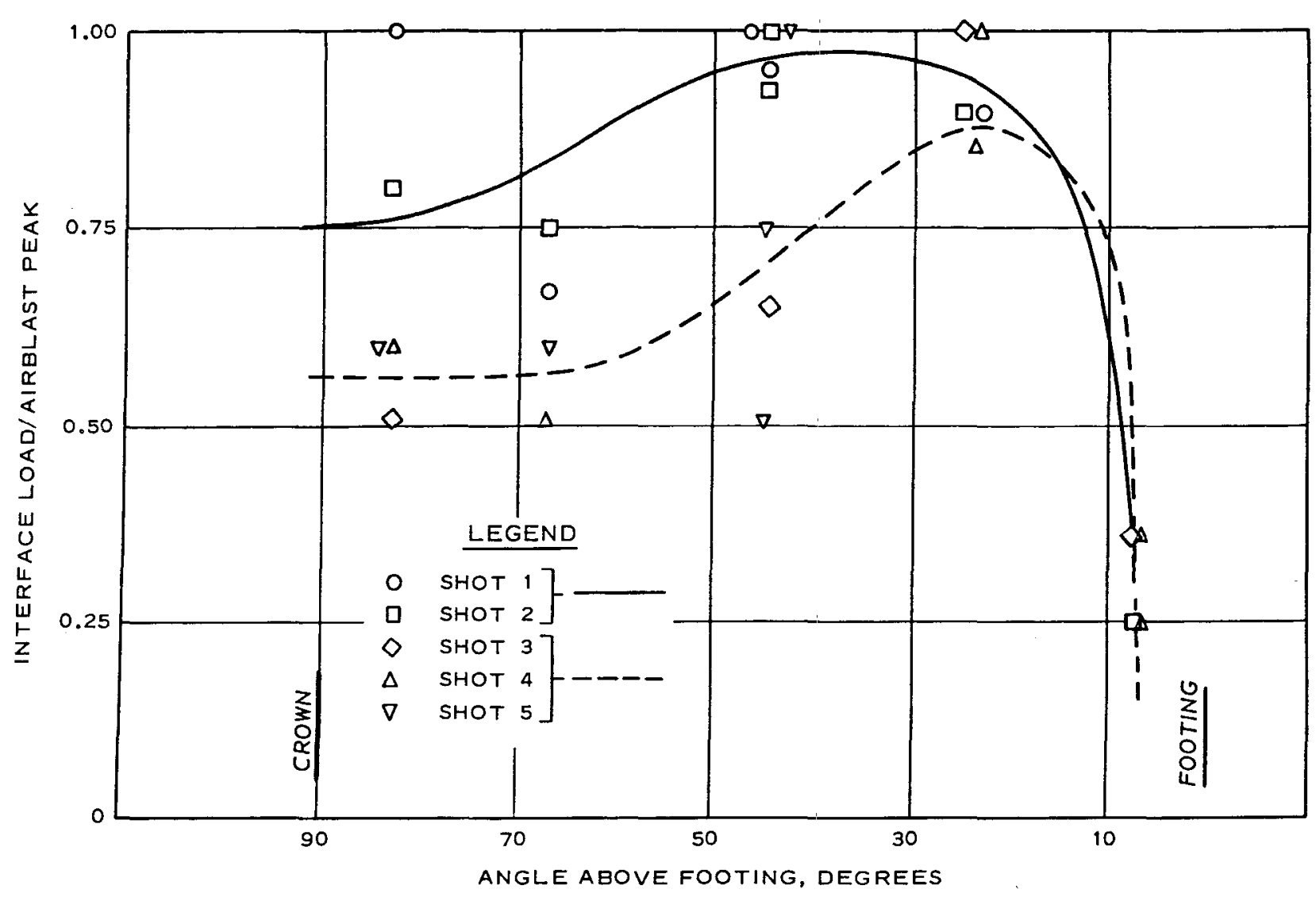

Figure 4.3 Radial load distribution. 


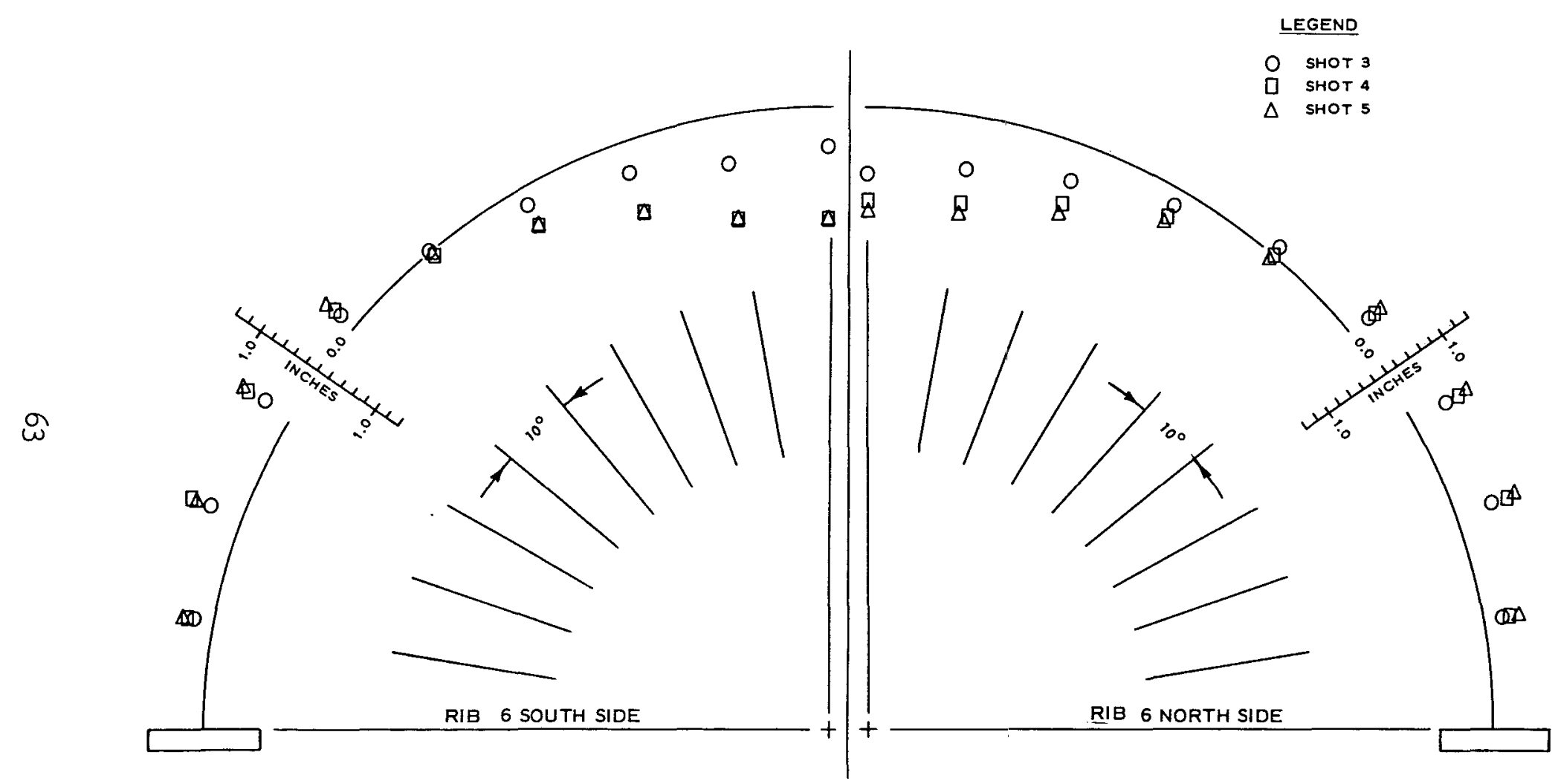

Figure 4.4 Permanent deformation of Rib 6 after Shots 3, 4, and 5 . 


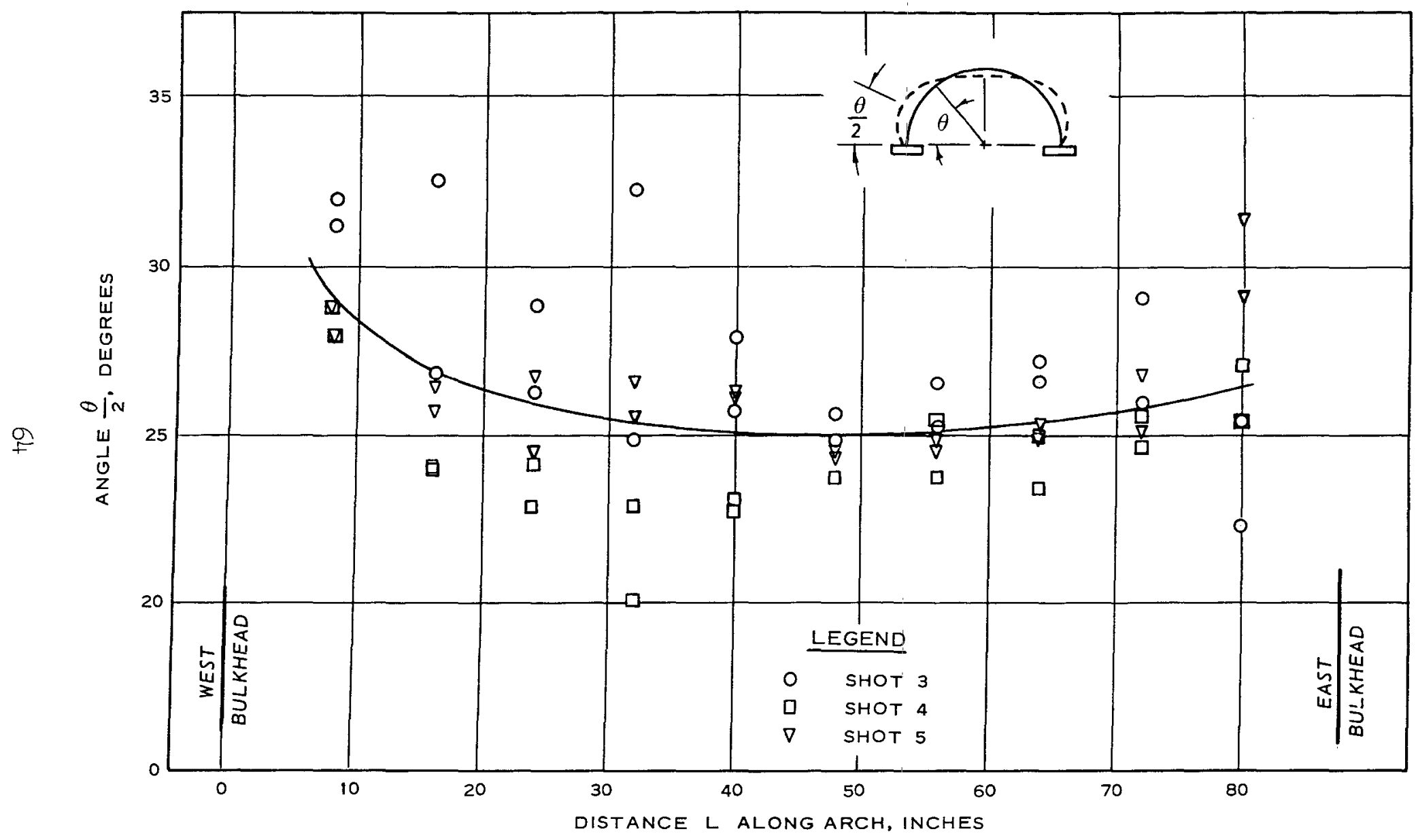

Figure 4.5 Angle of point of maximum outward deflection. 


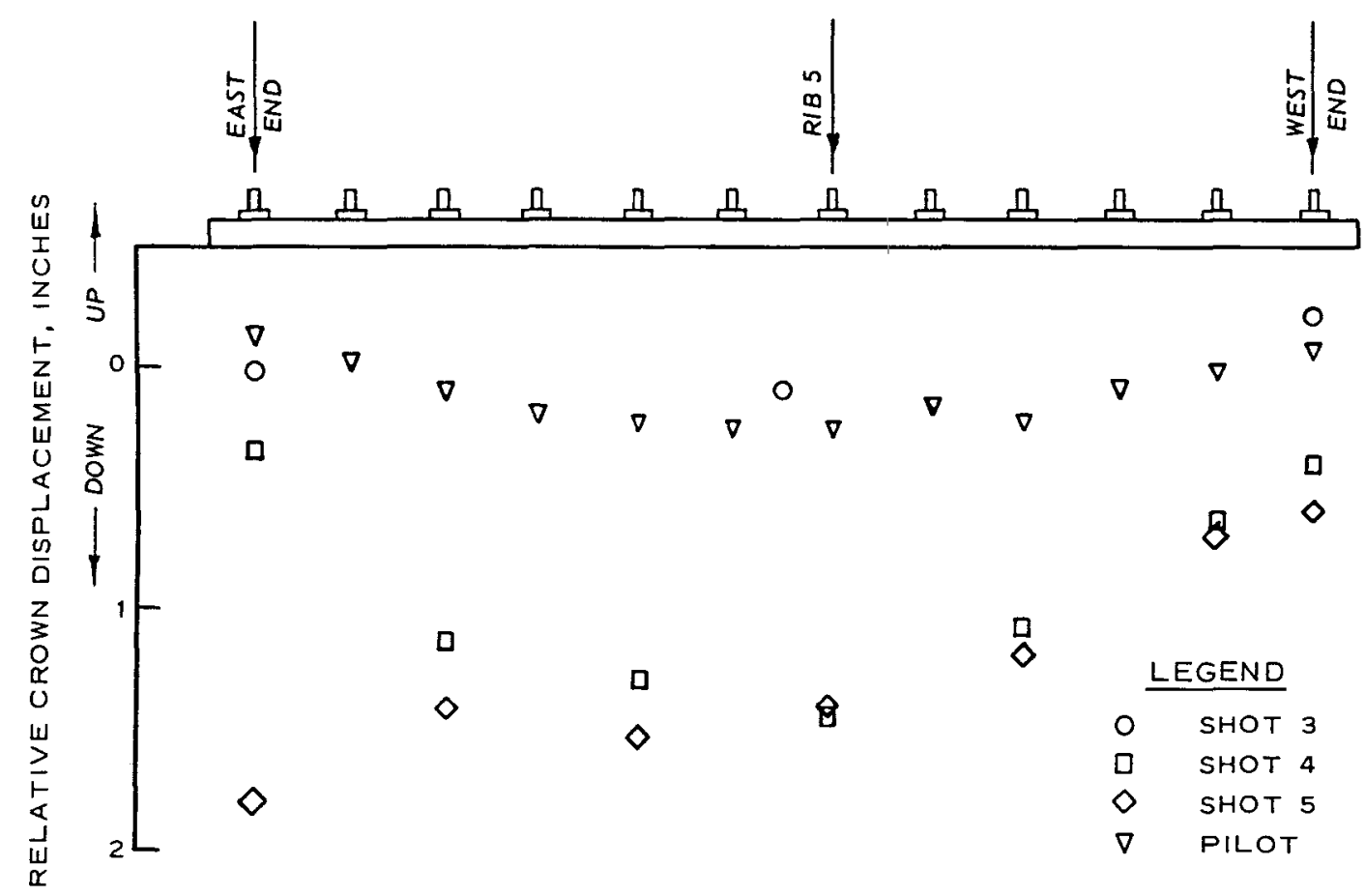

Figure 4.6 Level survey, postshot crown deflection with respect to the footings. 


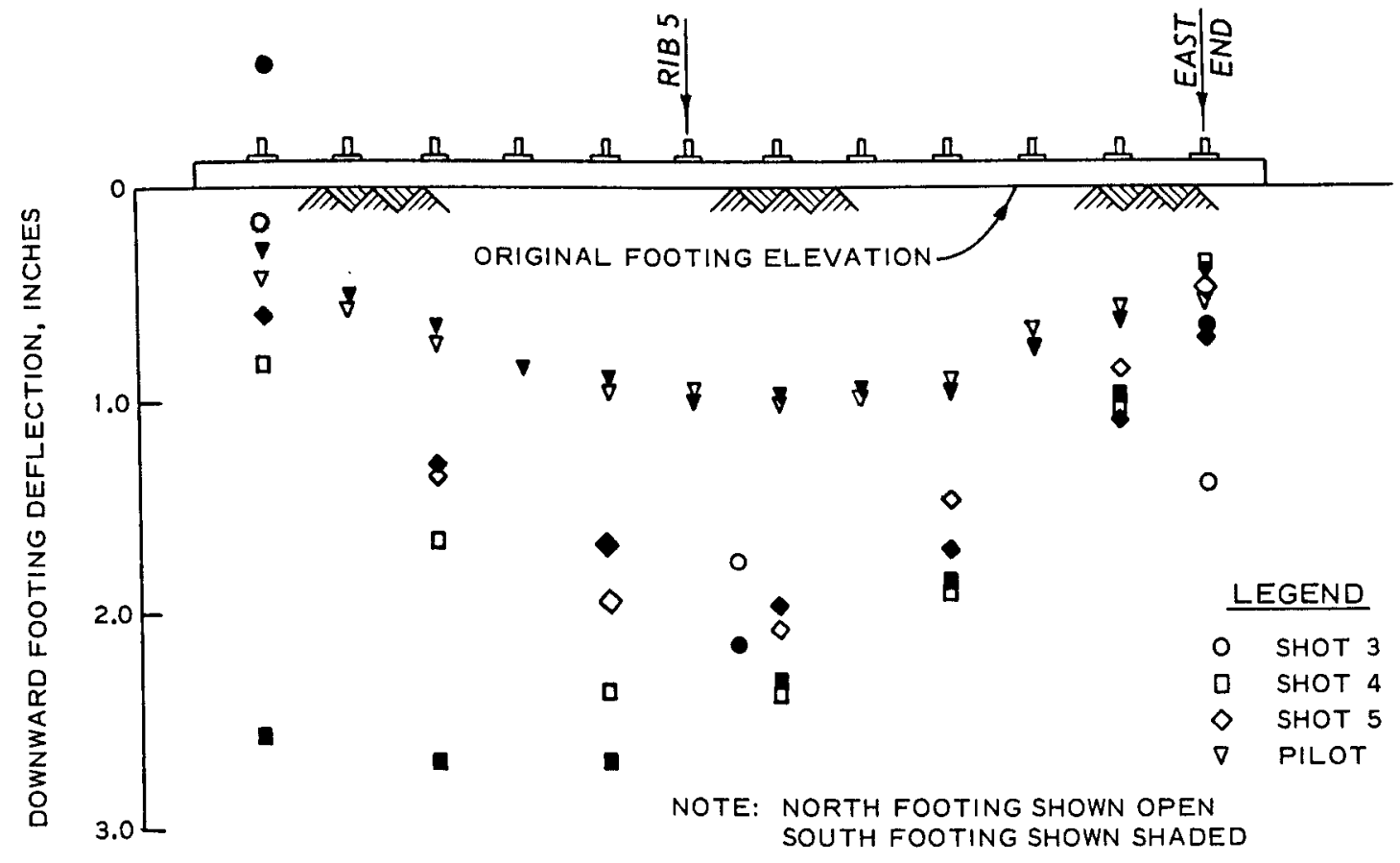

a. RAW DATA

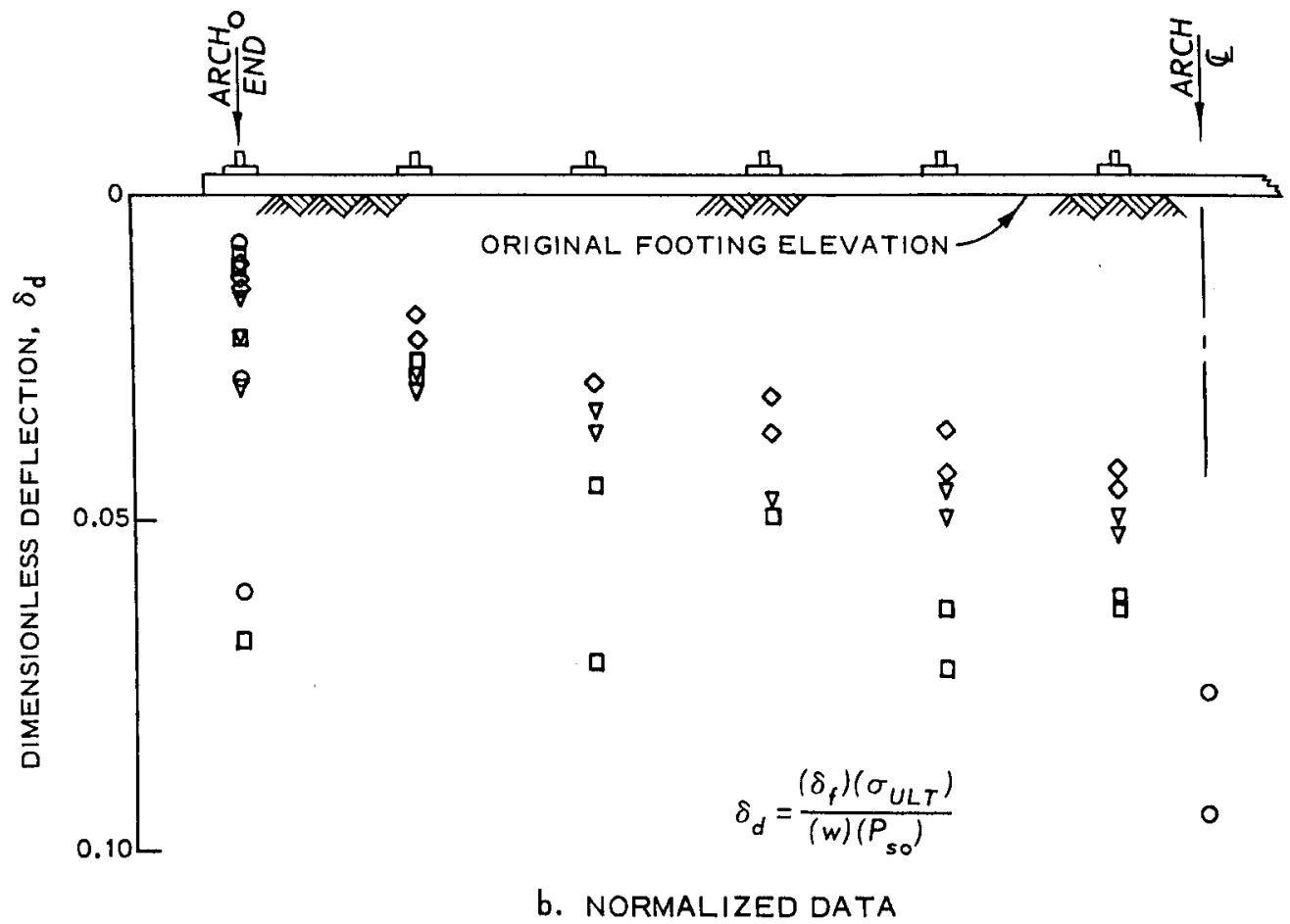

Figure 4.7 Level survey data for footings. 


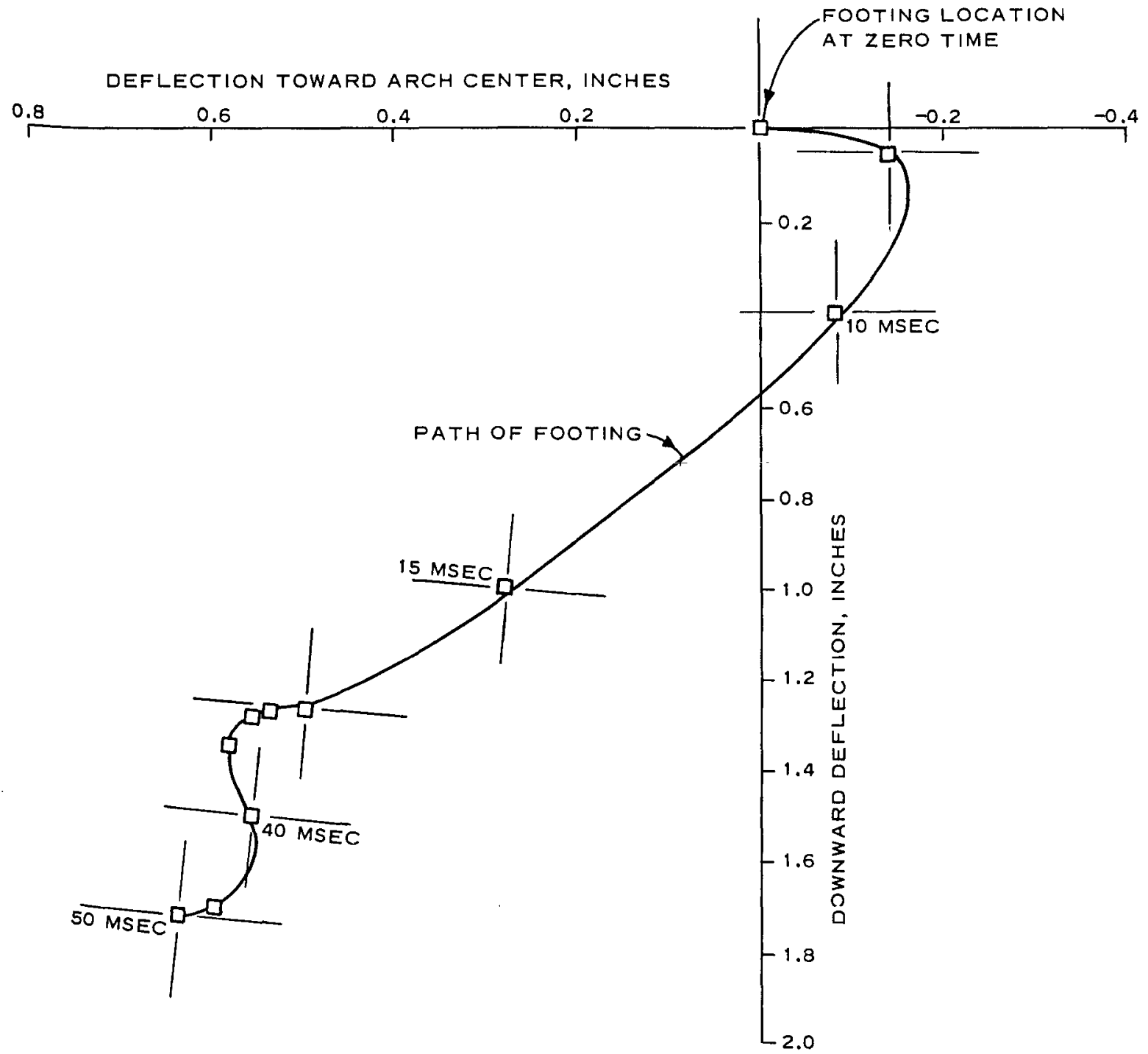

NOTE: EACH SQUARE REPRESENTS A 5-MSEC INTERVAL. THE ANGLE OF THE LINES WITH THE SQUARE REPRESENTS THE ANGLE OF THE FOOTING AT THAT TIME.

Figure 4.8 Footing motion of the north footing center during Shot 3 . 


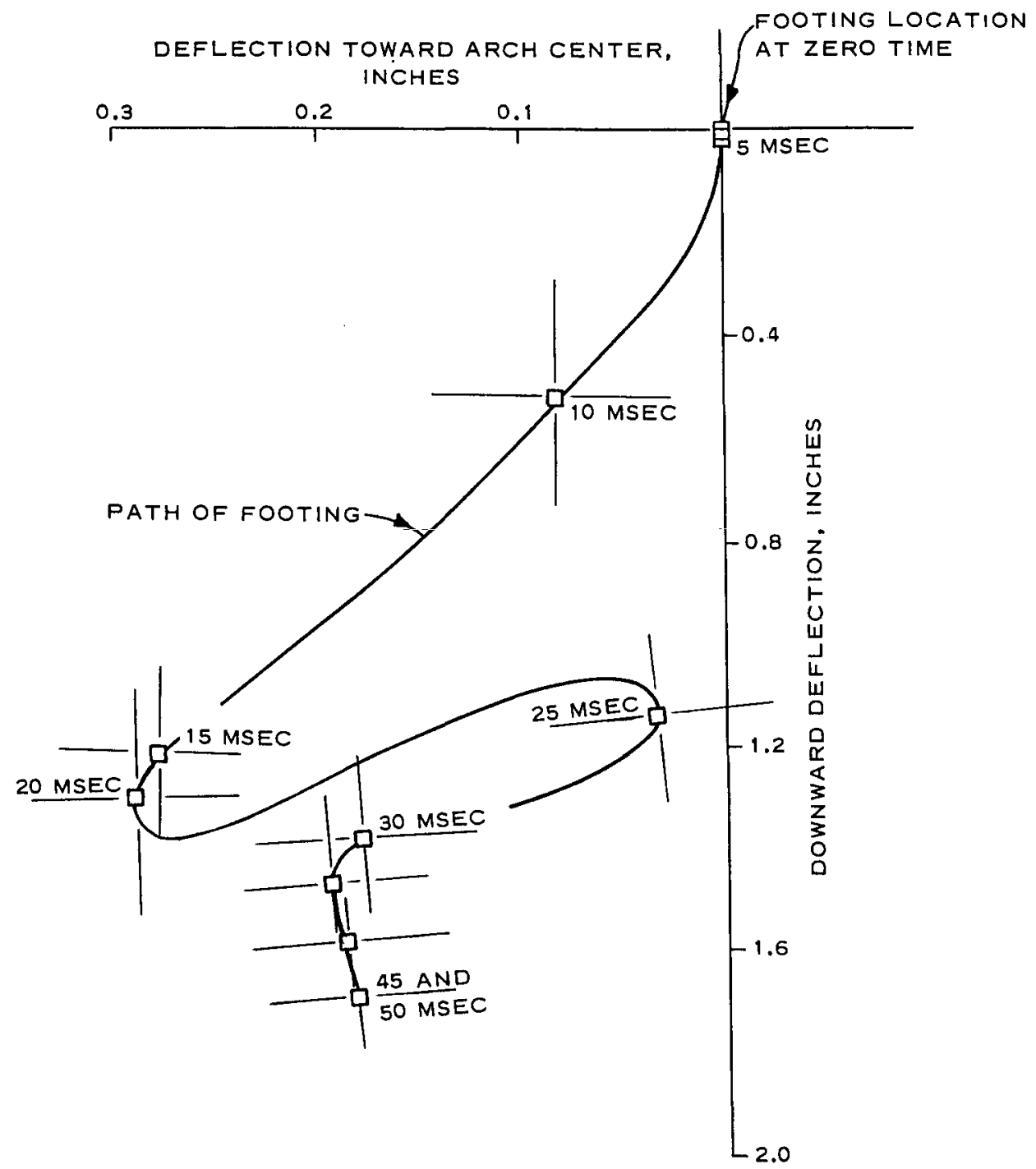

NOTE: EACH SQUARE REPRESENTS A 5-MSEC INTERVAL. THE ANGLE OF THE LINES WITH THE SQUARE REPRESENTS THE ANGLE OF THE FOOTING AT THAT TIME.

Figure 4.9 Footing motion of the north footing center during Shot 4. 


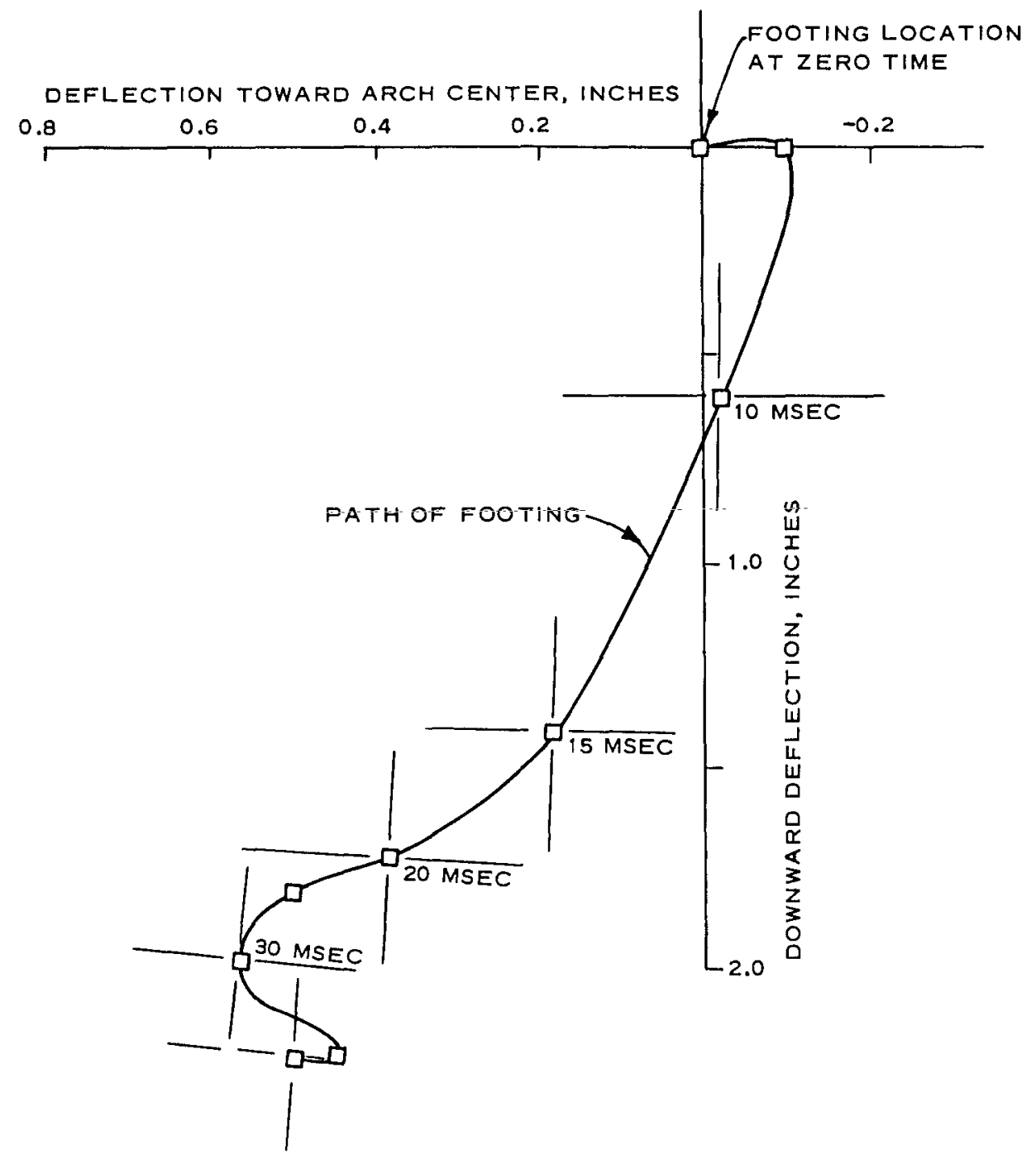

NOTE: EACH SQUARE REPRESENTS A 5-MSEC INTERVAL. THE ANGLE OF THE LINES WITH THE SQUARE REPRESEN TS THE ANGLE OF THE FOOTING AT THAT TIME.

Figure 4.10 Footing motion of the north footing center during Shot 5 . 


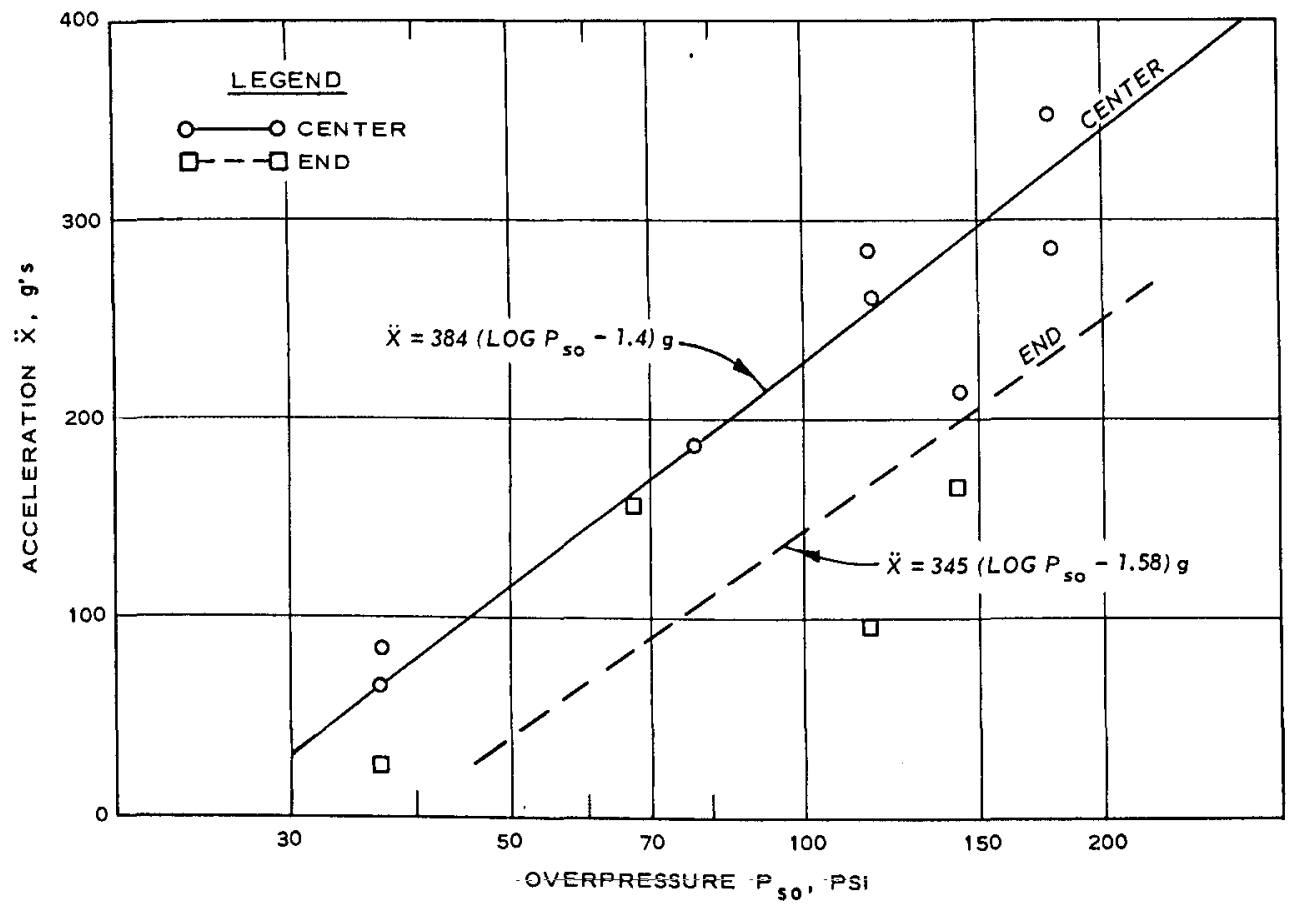

Figure 4.11 Peak acceleration of footing.

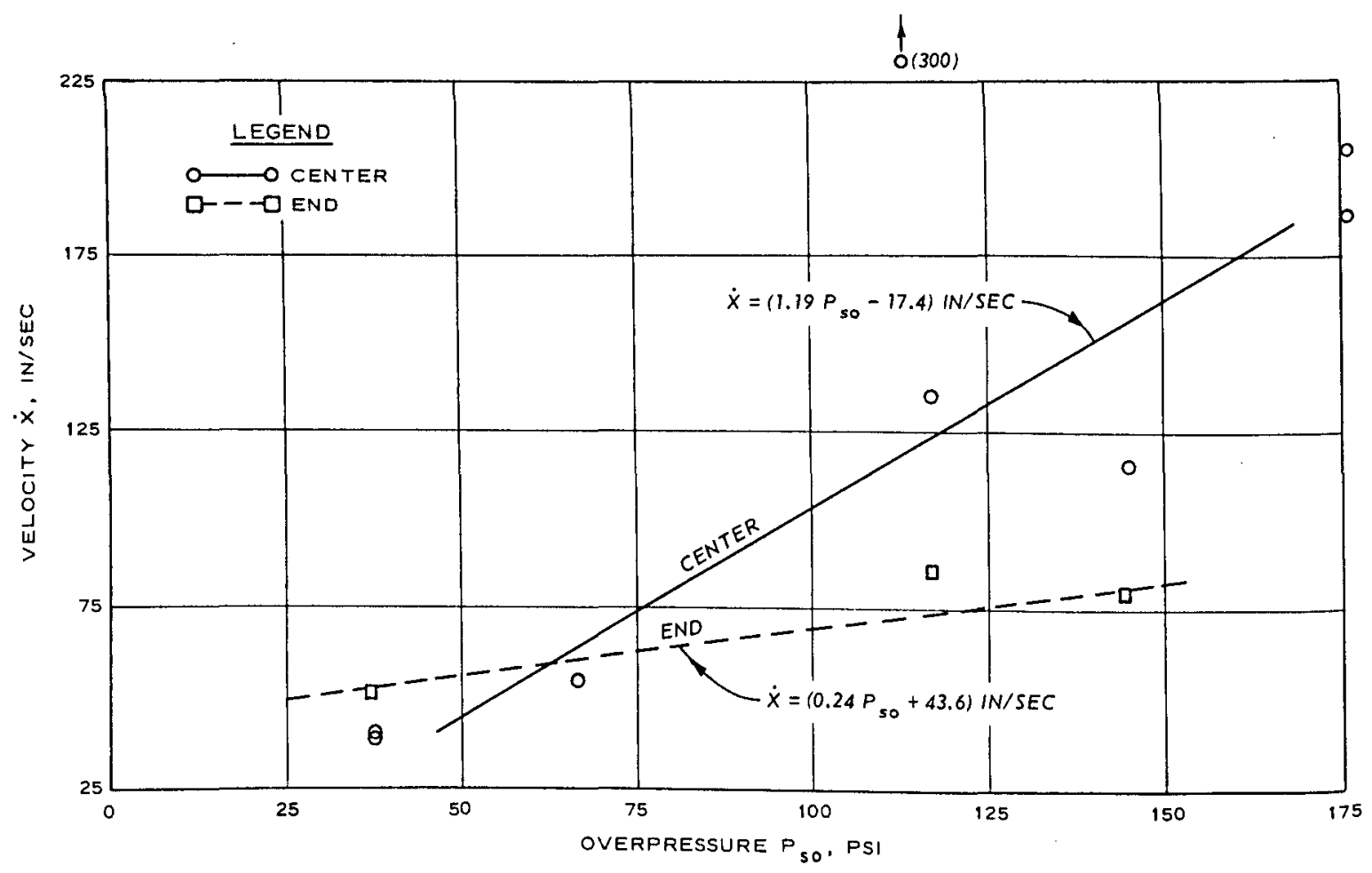

Figure 4.12 Peak velocity of footing. 

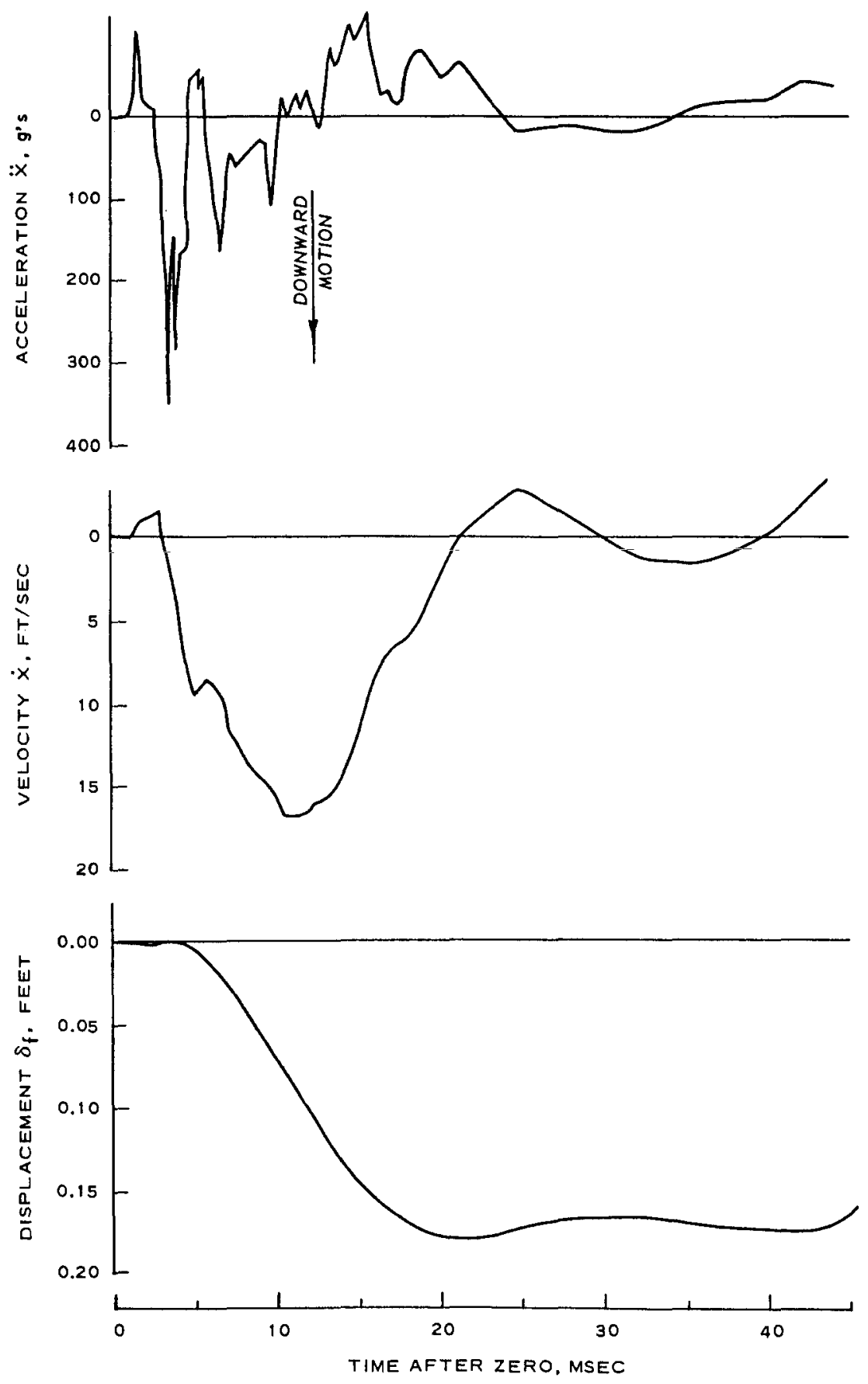

Figure 4.13 Typical motion data at footing center; shot 5, Gage 53VA. 


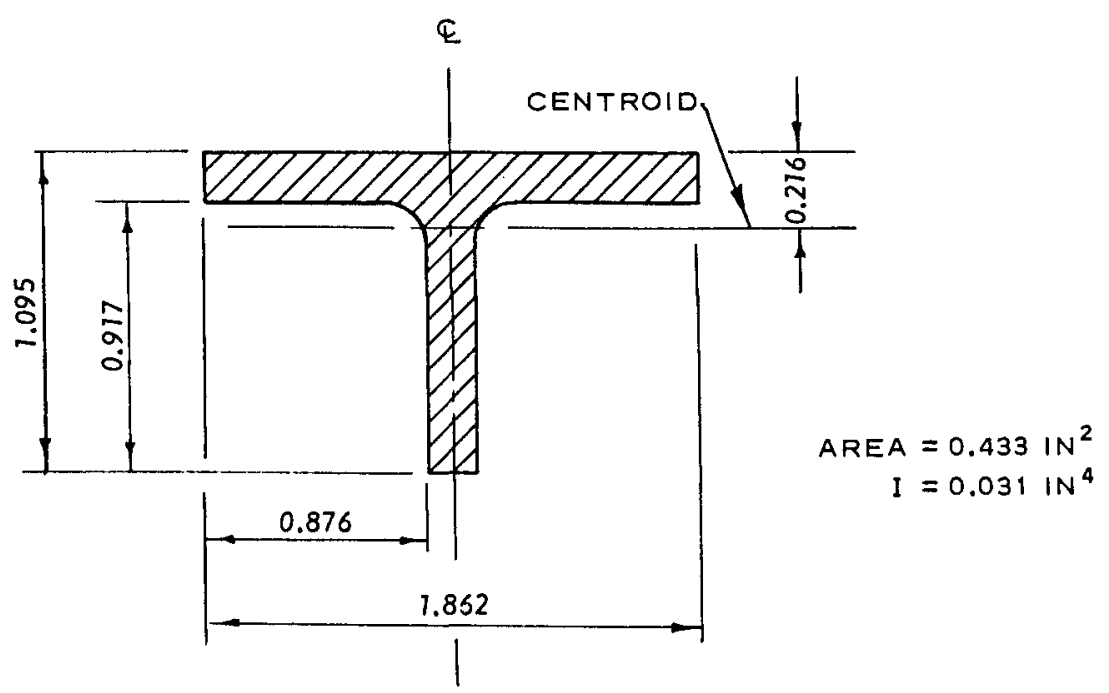

a. Physical dimensions (in inches) of a typical rib section.

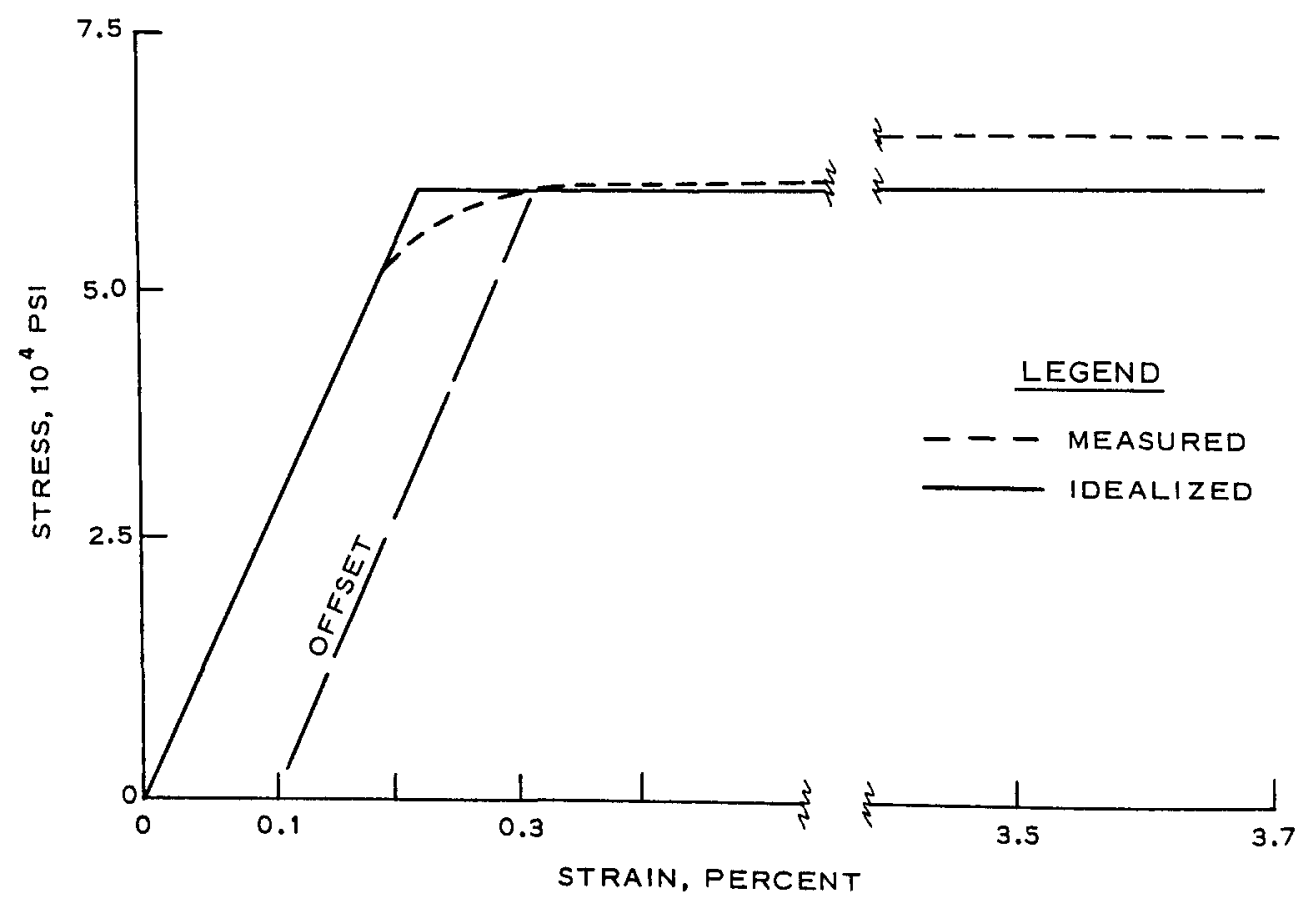

b. Stress-strain curve of steel.

Figure 4.14 Rib idealization. 


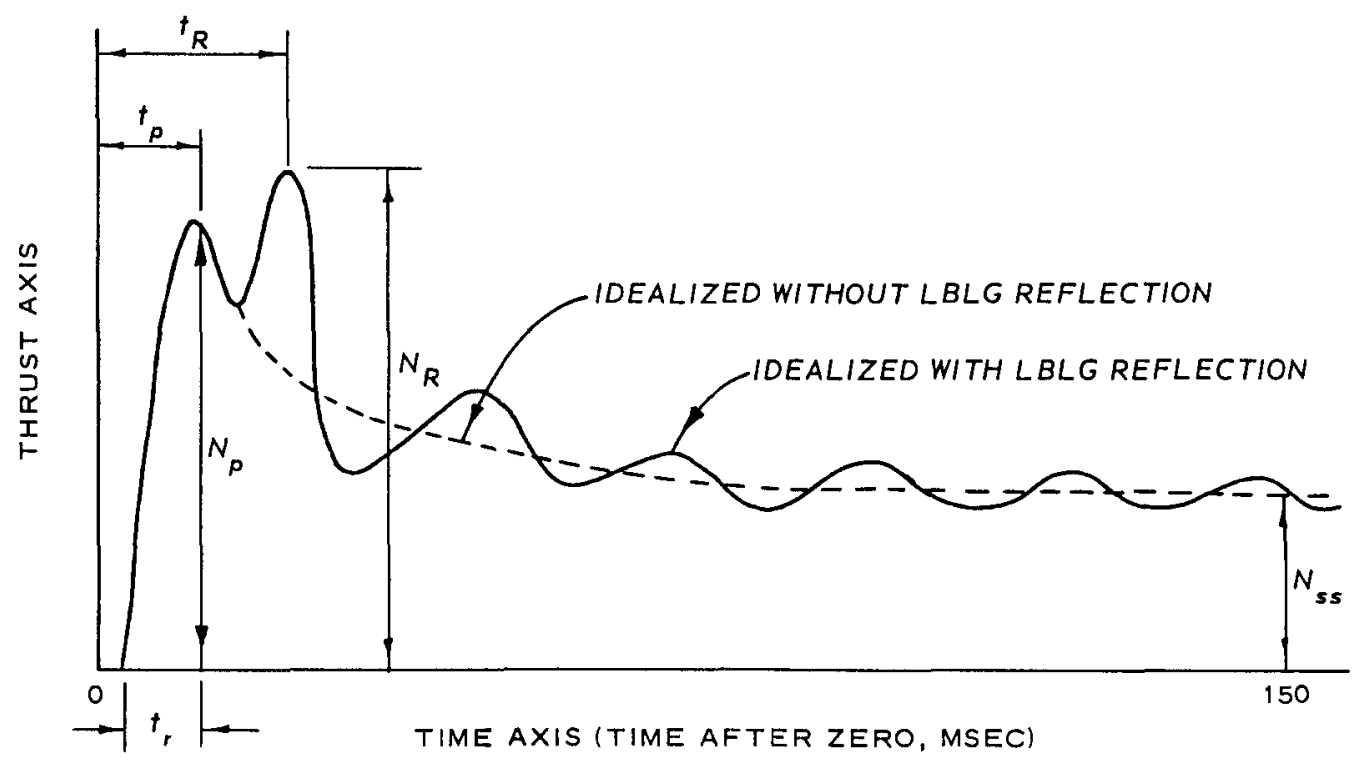

a. Thrust.

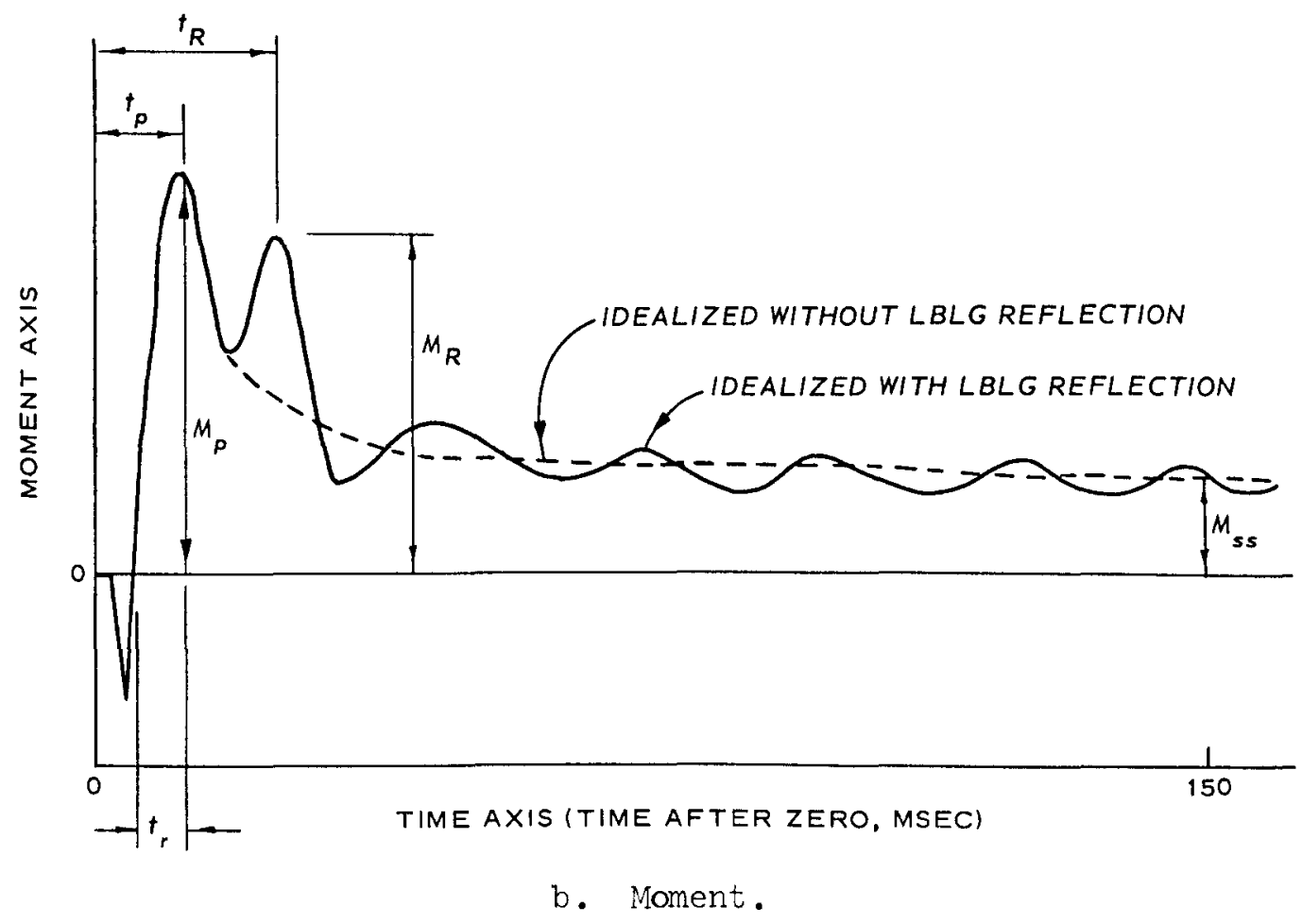

Figure 4.15 Idealized thrust and moment histories. 

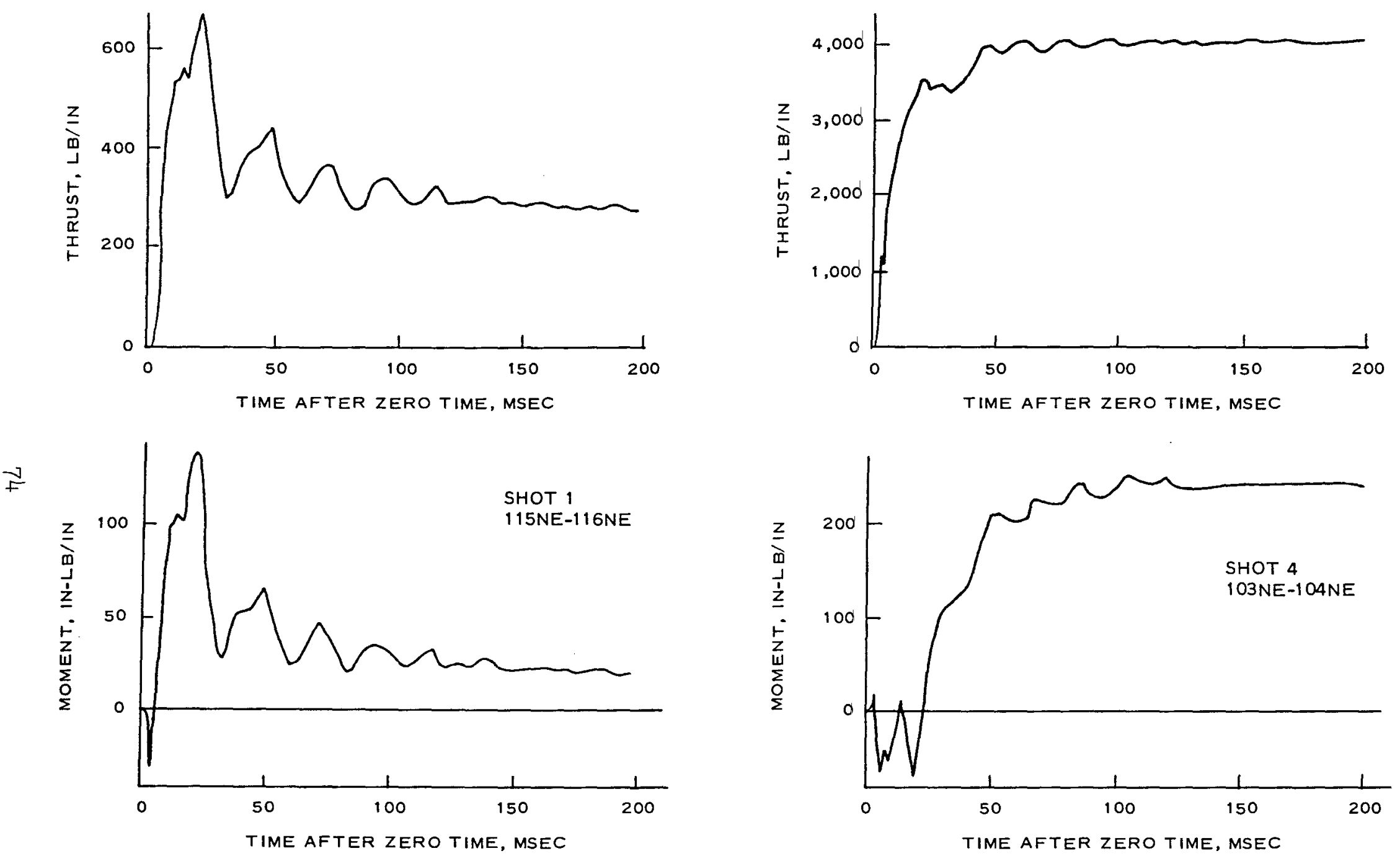

a. ELASTIC SECTION

b. PLASTIC SECTION

Figure 4.16 Typical elastic and plastic thrust and moment data. 


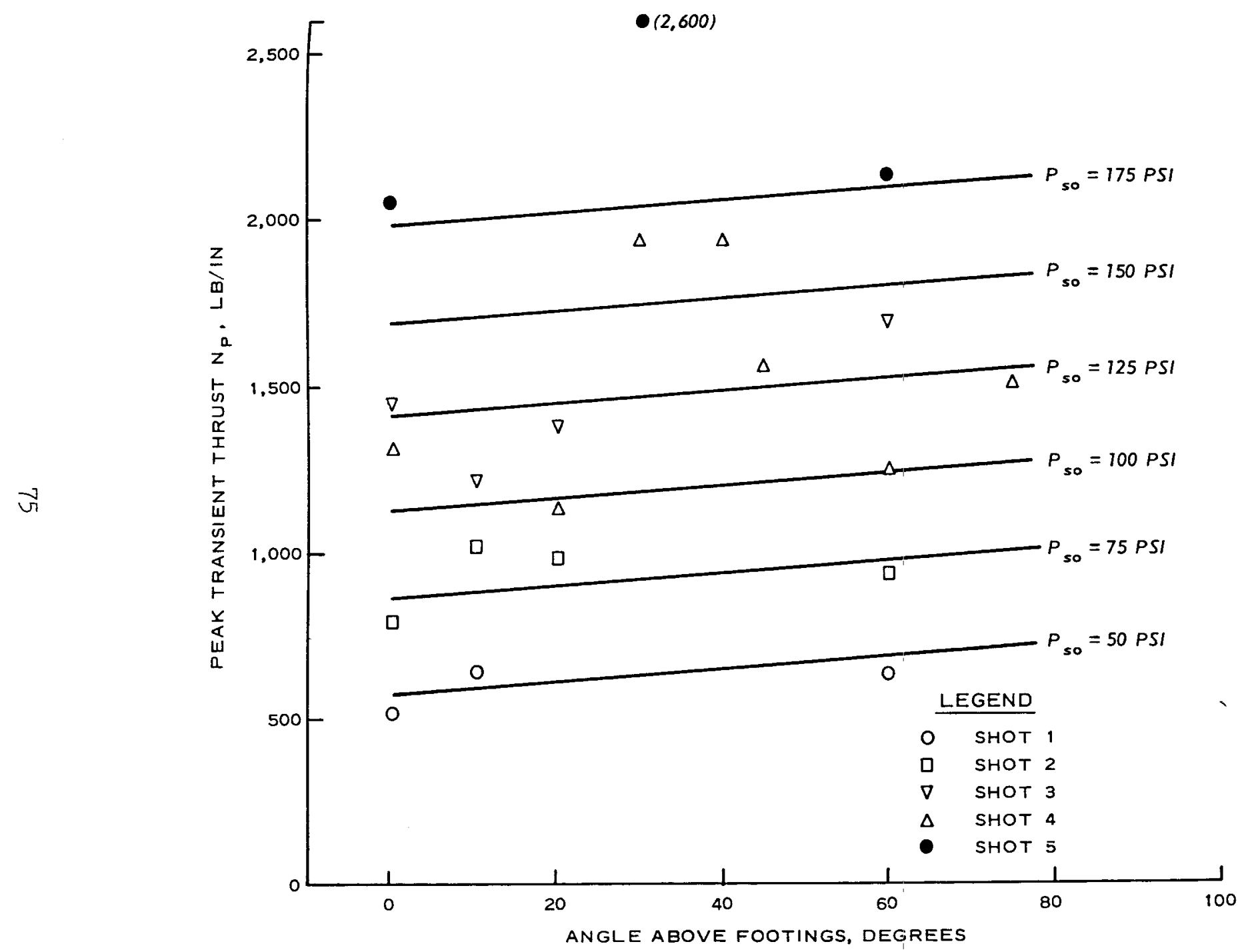

Figure 4.17 Peak transient thrust. 


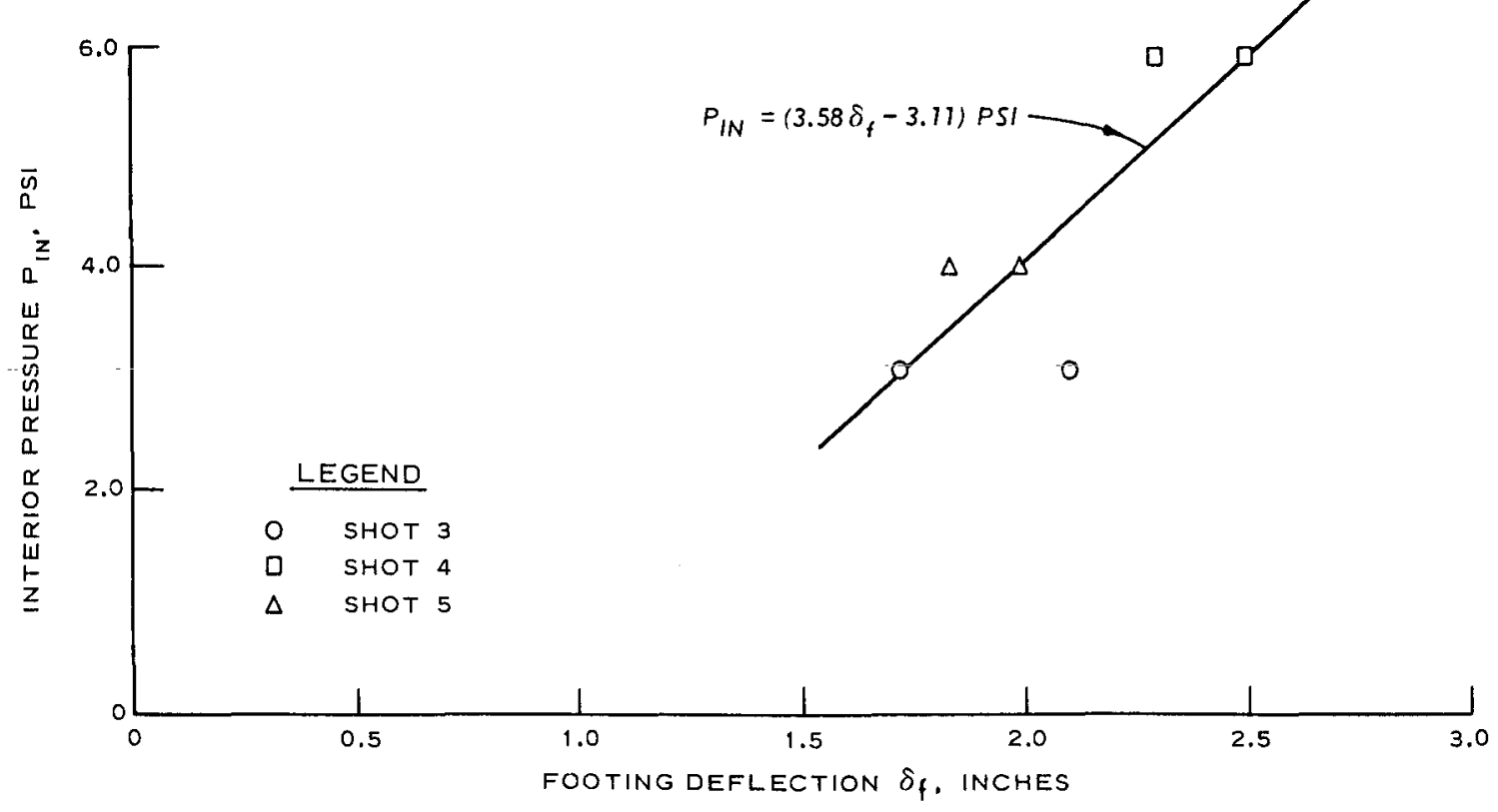

Figure 4.18 Peak interior pressure versus footing deflection. 

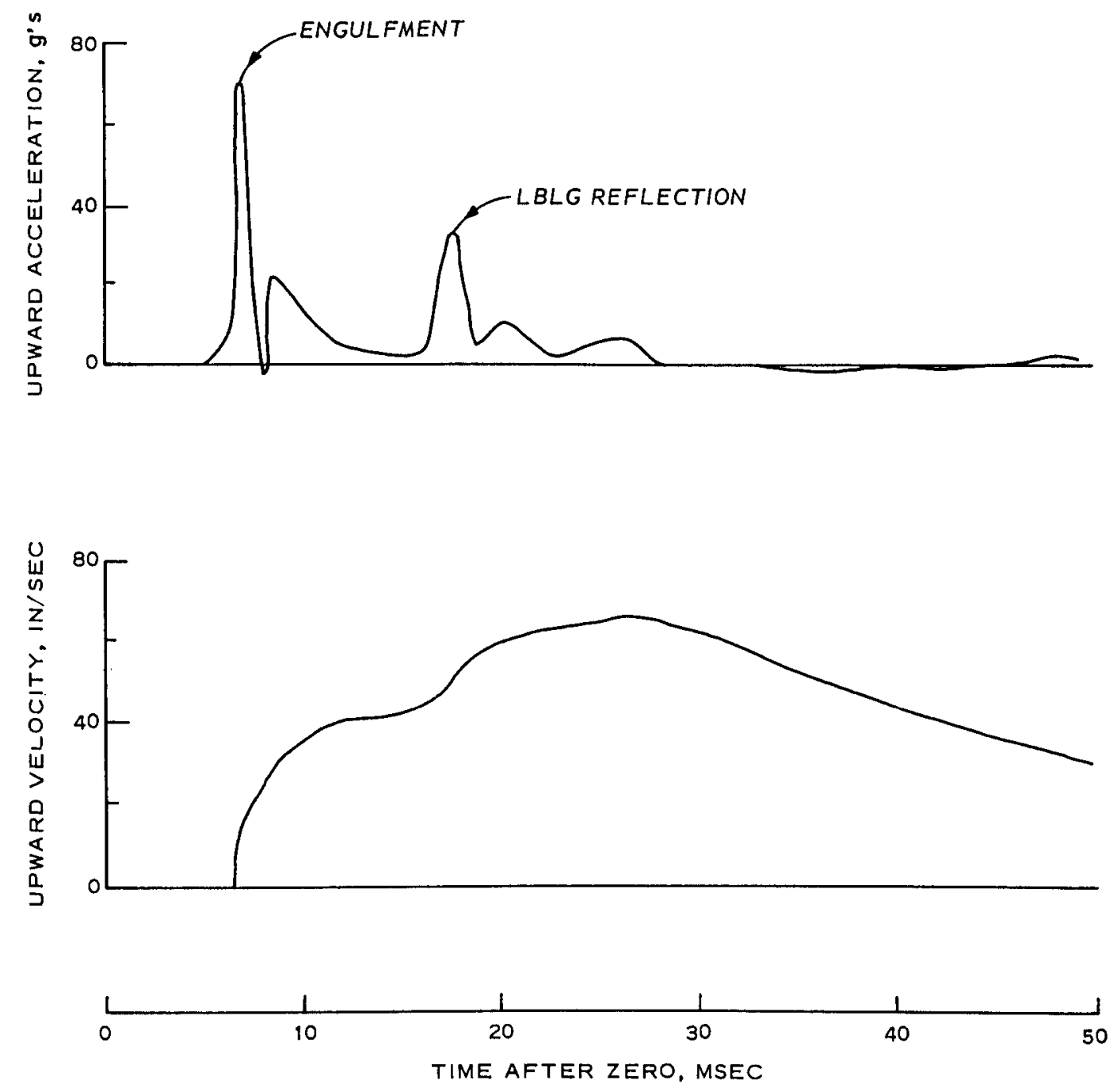

Figure 4.19 Acceleration- and velocity-time histories of the interior floor, Shot 4 (Gage 5lVA). 

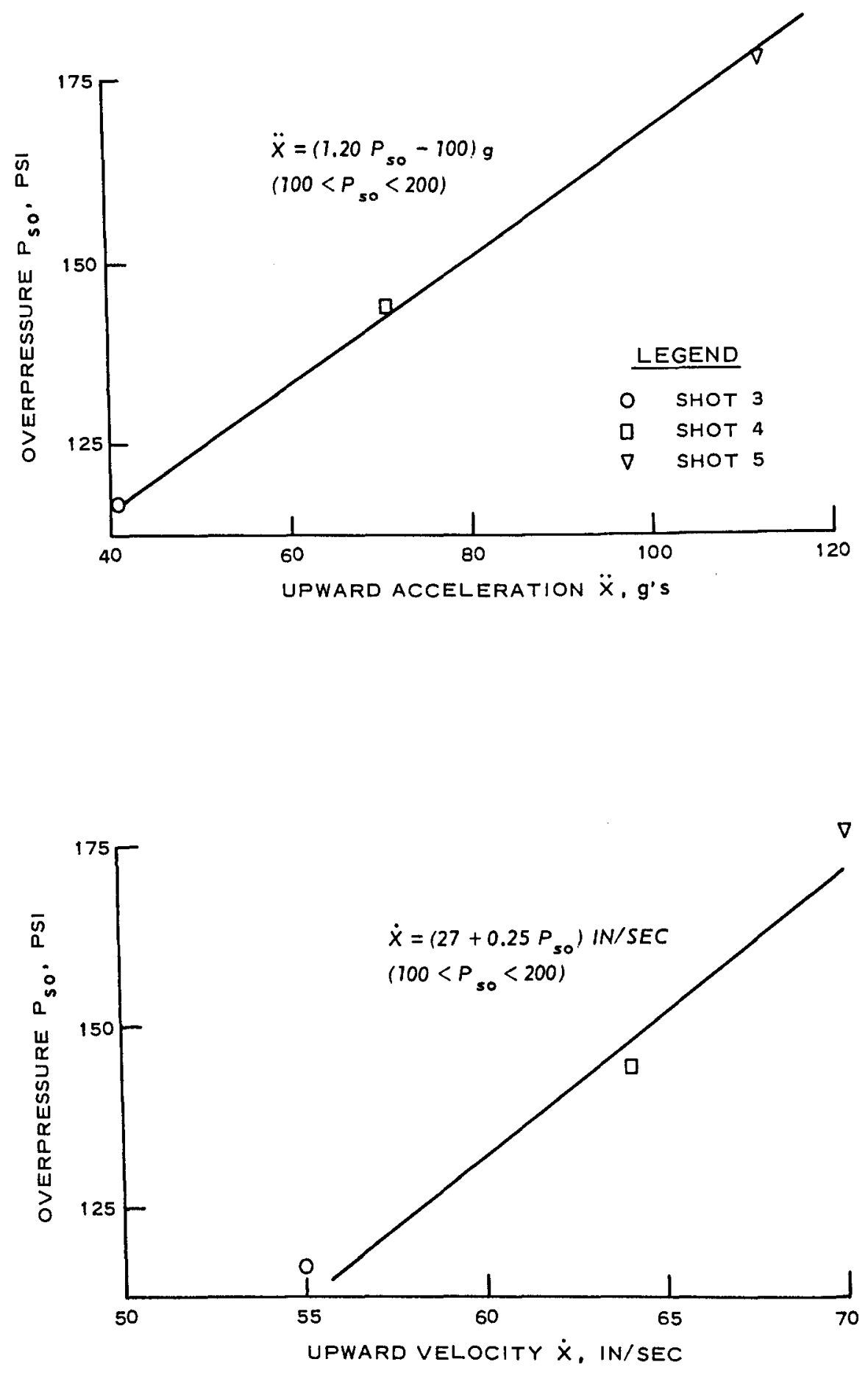

Figure 4.20 Peak motions of the interior floor (Gage 51VA). 


\section{CONCLUSIONS AND RECOMMENDATIONS}

\subsection{CONCLUSIONS}

The structure as tested easily withstood the design overpressure of $100 \mathrm{psi}$ with little damage, and in subsequent testing withstood almost twice the design overpressure. Since the reflected stress wave from the bottom of the test chamber tends to stop the motion of the structure, it is concluded that the relative displacements experienced in the laboratory are somewhat less than those which would be experienced in the field, whereas the stress levels in the structure are higher in the laboratory tests due to the reflected stress wave.

It is concluded that the revised truss as outlined in Appendix $D$ is workable and an improvement over the original design. The bulkhead design appears to be more than adequate, probably a bit more overdesigned than the arch itself.

Limited spalling tests indicate that dust inhalation could be a problem in the prototype, and some means of dust prevention such as oiling the interior floor should be considered.

It is believed that with a minimum redesign the overpressure resistance of the structure can be increased to near $200 \mathrm{psi}$ for a 1-Mt weapon. However, because the earth cover provides minimum protection from radiation effects at $100 \mathrm{psi}$, the depth of cover would have to be increased to provide protection at this overpressure level with the lower yield weapons producing the critical radiation levels.

\subsection{RECOMMENDATIONS}

Based on the laboratory findings, it is recommended that the bulkhead truss connection be redesigned as outlined in Appendix D. This redesign will eliminate problems occurring as a result of truss rotation. With regard to the truss itself, it is recommended that a cheaper configuration be designed. It is possible to use a pair of the arch ribs laid flat and connected to the bulkhead column bases by rods.

It is recommended that spikes be used to fasten the ribs to the 
footings rather than lag screws, since the only purpose served by these connectors is to position and to resist a small amount of shear. The spikes are cheaper and faster to use. It also appears possible to decrease the thickness of the wooden arch blocks, and it is recommended that this be considered.

If it is assumed that the hardness of the structure exceeds the original 100-psi design as the tests indicate, then it is recommended that the earth cover over the structure be increased to provide additional radiation protection. Exactly how much protection is required will depend upon the mission of the protected personnel.

Because of the large amount of settlement that will be associated with the response of this structure, any lines, wires, pipes, etc., will have to be designed for this relative motion between the components and the structure. It is recommended that flexible couplings be used with these components.

The entranceway described in Reference 1 is complex and quite expensive. It is recommended that, for general use, an entranceway be fabricated of concrete pipe cattle pass with a steel vertical shaft and blastproof door of the type shown in Reference 1 . With this entranceway, the use of corrugated-steel pipe to form a ventilation duct at either end of the structure with a blast-activated blast valve is recommended. It is further recommended that an emergency exit be provided that is constructed of corrugated-steel pipe and filled with sandbags and has a concealed surface exit.

The test series reported herein was conducted in dense, dry sand in a plane-wave device. It is recommended that (1) tests be conducted in soils other than dry sand in the same device, and (2) a field test of a larger model be conducted in sand to determine the severity of the laboratory environment as opposed to the field. It is also recommended that limited instrumentation be used with these tests, with emphasis being put on the footing response and the interior environment, as a means of correlating the laboratory and field results. By extrapolating these data to the prototype, to other soil types, and to modified construction, a structural analysis can be developed based on a discrete approximation to the structure. 
APPENDIX A

INSTRUMENTATION DETAIIS

AND TABULATED RESULTS 
The Large Blast Load Generator facility is ideally suited for conducting heavily instrumented tests on structures of the type tested in this study. An ultimate capability of nearly 100 data channels (Figure A.I) means that large quantities of information can be obtained from a single test. With tests requiring approximately 100 data channels such as are reported herein, no single system of instrumentation can be used, and care must be exercised to see that frequencies of systems are compatible with what is being measured. Diagrams of the test instrumentation hookup are shown in Figure A.2. Magnetic tape was used for primary data recording and was backed up with recording oscillograph equipment. Since only about 50 channels of tape were available, it was not possible to use tape in all cases. Consequently, some data were recorded only on oscillograph recorders. The system used was composed essentially of three parts: transducers, amplifiers, and recorders. All strain gages used on the steel elements were manufactured by the Budd Company and were foil-type high-elongation gages with a resistance of 120 ohms. Strain in the wooden components was measured with 1- by 1/8-inch high-elongation foil-type gages manufactured by the Budd Company. Deflections were measured using 6-inch-range LVDTtype transducers manufactured by Crescent Instruments. Piezoelectric accelerometers from Columbia Instruments and strain-gage-type accelerometers from Consolidated Electrodynamics Corporation (CEC) were used to measure acceleration. Soil pressure was measured using W-type transducers (Shots 1 and 2) developed at the Waterways Experiment Station (Reference 8) and using Road Research Cells (RRC) (Shots 3, 4, and 5) from the Road Research Laboratories (Reference 9). Overpressure at the soil surface was monitored using Norwood blast-pressure transducers, and air pressure in the structure was monitored using a CEC pressure transducer. Figure A.3 is a photograph of all the transducers used.

Various amplifiers were used to condition the signals prior to recording. Three carrier systems manufactured by CEC were used, the 1-118 with a 3-kcps response, the 1-127 with a 20-kcps response, and the System $D$ with a 3-kcps response. Dana 2000-DC amplifiers and Alinco Model SAM 1 amplifiers were also used. In use with the piezoelectric transducers were Kistler Model 65656 charge amplifiers. Final recording of the data was 
done using CEC-type 5-119 galvanometer oscillographs at paper speeds of $160 \mathrm{in} / \mathrm{sec}$ and Sangamo Model 472RB and Ampex Model ES-100 magnetic-tape recorders.

The frequency response of the total system varied, depending on the recording equipment. In the case of the magnetic-tape data channels, the frequency limitation was the transducer response since the tape equipment had a 20-kcps capability. In the case of the oscillograph-data channels, the frequency response limitations were caused by the type of galvanometer used in the system. Table A.I is a tabulation of the maximum frequency response of each recorder used.

The LBLG has the advantage of providing a fixed reference to which all motion measurements can be referenced. To take advantage of this, a 6-inch-square steel column was welded to the center of the floor of the LBLG and extended upward to the level of the structure footings. It was necessary to measure three vertical components of deflection to determine the rigid body motion of the footing since it had three degrees of freedom. Consequently, a rig mounting three deflection gages was designed and rigidly attached to the steel column. The deflection gages were attached to the footing by means of rollers, pin joints, and a rocking beam as shown in Figure A.4. The crown deflection in Shots 1, 2, and 3 was tied into this reference column. During shots 3 and 4 , a steel angle rod was extended toward the east bulkhead and a deflection gage (O1HD) was mounted on this rod to measure the base deflection of Bulkhead Beam 2. This gage and mounting rod can be seen in Figure A.5. This figure shows the instrumentation in place prior to sand placement for shot 3 .

Figures A.6 and A.7 show the gage locations used and the numbering system used with the ribs and bulkhead beams throughout the test series. Tables A.2 through A.6 give a detailed tabulation of various peaks, times of arrival, etc., considered to be of greatest importance. Appendix $B$ contains the raw records from which Tables A.2 through A.6 were made.

The gage designations in Tables A.2 through A.6 indicate the type of measurement and the gage location.

For the air pressure and soil stress gages (Tables A.2 and A.3), the first two letters indicate the type of measurement, as follows: 
SS - soil stress.

SP - surface airblast pressure.

$I P$ - interior air pressure.

The final number is a location number which, for the soil stress gages, is odd for a horizontal gage and even for a vertical gage.

Gage designations for accelerometers and deflection gages (Tables A.4 and A.5) are four characters, indicating:

1. The rib nearest to or upon which the gage is placed (see Figure A.6). Omitted for free-field gages.

2. Location.

3. $\mathrm{V}$ - vertical, $\mathrm{H}$ - horizontal.

4. A - acceleration, or D - deflection.

Gage designations for strain gages (Table A.6) are also four characters, indicating:

1. The rib or column nearest to or on which the gage is placed (see Figure A.6).

2. Location. In general, even for extrados and odd for intrados.

3. N - north, S - south, E - interior, or W - exterior.

4. E - arch strain, B - timber block strain, C - bulkhead column strain. 
TABLE A.I OSCILLOGRAPH SYSTEM FREQUENCY RESPONSE

\begin{tabular}{ccccc}
\hline Recorder & \multicolumn{4}{c}{ Maximum Response, cps } \\
\cline { 2 - 5 } & $\begin{array}{c}\text { Shots } 1 \\
\text { and 2 }\end{array}$ & Shot 3 & Shot 4 & Shot 5 \\
\hline 1 & 1,000 & 1,000 & 1,000 & 1,000 \\
2 & 1,000 & 1,000 & 1,000 & 1,000 \\
3 & 2,500 & 2,500 & 2,500 & 1,000 \\
4 & 600 & 1,000 & 1,000 & 1,000 \\
5 & 600 & 1,000 & 1,000 & -- \\
6 & -- & 2,500 & 2,500 & --
\end{tabular}


TABLE A.2 AIRBLAST RESULTS

NR - No interpretable record.

\begin{tabular}{|c|c|c|c|c|}
\hline Shot & $\begin{array}{l}\text { Gage } \\
\text { No. }\end{array}$ & $\begin{array}{l}\text { Spike } \\
\text { Peak }\end{array}$ & $\begin{array}{l}\text { Averaged } \\
\text { Peak }\end{array}$ & $\begin{array}{l}\text { loo-msec } \\
\text { Level }\end{array}$ \\
\hline & & $\mathrm{psi}$ & psi & psi \\
\hline 1 & SPI & 54 & 39 & 22 \\
\hline$I$ & SP2 & 38 & 34 & 19 \\
\hline 1 & $\mathrm{BPI}(7362)$ & 109 & 37 & 23 \\
\hline 1 & $\mathrm{BP} 2(7369)$ & 70 & 39 & 21 \\
\hline 2 & SPI & 81 & 45 & 24 \\
\hline 2 & SP2 & 82 & 64 & 53 \\
\hline 2 & $\mathrm{BPI}(7362)$ & 123 & 70 & 57 \\
\hline 2 & $\mathrm{BP} 2(7369)$ & 103 & 64 & 49 \\
\hline 3 & SPI & 132 & 117 & 76 \\
\hline 3 & SP2 & 243 & 117 & 79 \\
\hline 3 & SP3 & 117 & 106 & 56 \\
\hline 3 & $\mathrm{BPI}(7367)$ & 153 & 113 & 78 \\
\hline 3 & IPI & 3.1 & 3.1 & 3.1 \\
\hline 4 & SPI & 144 & 107 & 77 \\
\hline 4 & SP2 & 66 & 35 & 32 \\
\hline 4 & SP3 & $\mathrm{NR}$ & $\mathrm{NR}$ & NR \\
\hline 4 & BPI (6965) & 178 & 143 & 126 \\
\hline 4 & $\mathrm{BP2}(8622)$ & $\mathrm{NR}$ & $\mathrm{NR}$ & NR \\
\hline 4 & IPI & 5.9 & 5.9 & 4.9 \\
\hline 5 & SPI & 330 & 287 & 0 \\
\hline 5 & SP2 & 183 & 170 & 67 \\
\hline 5 & SP3 & 230 & 180 & 71 \\
\hline 5 & $\mathrm{BPI}(7363)$ & 265 & 205 & 108 \\
\hline 5 & $\mathrm{BP2}(8551)$ & $\mathrm{NR}$ & NR & $\mathrm{NR}$ \\
\hline 5 & IPI & 4.0 & 4.0 & 3.2 \\
\hline
\end{tabular}

a $100 \mathrm{msec}$ after zero time. 
TABLE A.3 SOIL STRESS RESULTS

NR - No interpretable record.

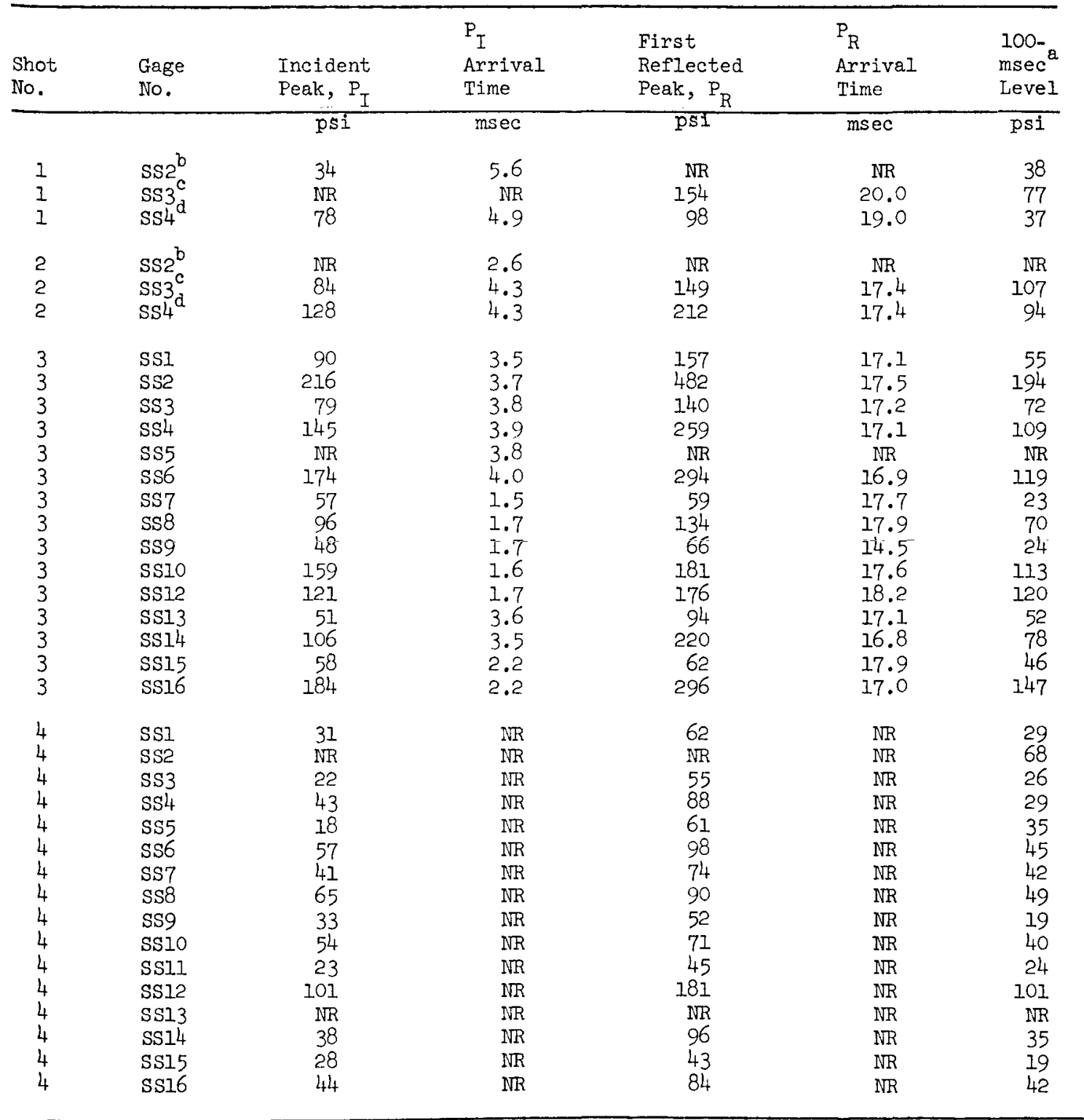

\footnotetext{
a $100 \mathrm{msec}$ after zero time.

Gage located 24 inches south of center of the south footing level with the crown. Measured vertical pressure.

c Gage located 24 inches north of center of the north footing level with the footing. Measured vertical pressure.

dage located 24 inches north of center of the north footing level with the crown. Measured vertical pressure.
} 
TABLE A.4 ACCELERATION RESULTS

NR - No interpretable record. Initial peak, largest first peak; second peak, largest peak in direction opposite initial peak. Peak velocity corrected during integration such that velocity is zero before $100 \mathrm{msec}$. Peak displacement, displacement based on the corrected velocity.

\begin{tabular}{|c|c|c|c|c|c|}
\hline Shot & $\begin{array}{l}\text { Gage } \\
\text { No. }\end{array}$ & $\begin{array}{l}\text { Initial } \\
\text { Peak }\end{array}$ & $\begin{array}{l}\text { Second } \\
\text { Peak }\end{array}$ & $\begin{array}{l}\text { Peak } \\
\text { Velocity }\end{array}$ & $\begin{array}{l}\text { Peak } \\
\text { Displacement }\end{array}$ \\
\hline & & $g^{\prime} s$ & $g^{\prime} s$ & in/sec & inches \\
\hline$I$ & $52 \mathrm{VA}$ & 84 Down & $13 \mathrm{Up}$ & 39 Down & 0.93 Down \\
\hline$I$ & $53 \mathrm{VA}$ & 68 Down & $22 \mathrm{Up}$ & 36 Down & 0.51 Down \\
\hline 1 & $54 \mathrm{VA}$ & 27 Down & $11 \mathrm{Up}$ & 24 Down & 0.54 Down \\
\hline 2 & 52VA & 189 Down & $55 \mathrm{Up}$ & 53 Down & 0.29 Down \\
\hline 2 & $53 V A$ & 168 Down & $26 \mathrm{Up}$ & NR & $N R$ \\
\hline 2 & $54 \mathrm{VA}$ & 159 Down & $55 \mathrm{Up}$ & 28 Down & 0.14 Down \\
\hline 3 & 5IVA & $41 \mathrm{Up}$ & 5 Down & $55 \mathrm{Up}$ & $1.75 \mathrm{Up}$ \\
\hline 3 & $52 \mathrm{VA}$ & 262 Down & $111 \mathrm{Up}$ & 136 Down & 2.28 Down \\
\hline 3 & 53VA & 286 Down & $287 \mathrm{Up}$ & 300 Down & 11.20 Down \\
\hline 3 & $54 \mathrm{VA}$ & 99 Down & $182 \mathrm{Up}$ & 88 Down & 2.19 Down \\
\hline 3 & $I H A$ & $224 a$ & 132 & $16^{a}$ & $0.04 \mathrm{a}$ \\
\hline 3 & $2 \mathrm{HA}$ & $175^{\mathrm{a}}$ & 100 & $6.5^{a}$ & $0.02^{2}$ \\
\hline 3 & 3VA & 1,864 Down & $784 \mathrm{Up}$ & 85 Down & 0.23 Down \\
\hline 3 & $4 \mathrm{VA}$ & NR & $\mathrm{NR}$ & NR & NR \\
\hline 4 & 5IVA & $71 \mathrm{Up}$ & 5.7 Down & $64 \mathrm{Up}$ & $2.11 \mathrm{Up}$ \\
\hline 4 & $52 \mathrm{VA}$ & 213 Down & $132 \mathrm{Up}$ & 117 Down & 1.26 Down \\
\hline 4 & 53VA & NR & NR & $\mathrm{NR}$ & NR \\
\hline 4 & $54 \mathrm{VA}$ & 167 Down & $76 \mathrm{Up}$ & 79 Down & 0.88 Down \\
\hline 4 & $55 \mathrm{CA}$ & $\mathrm{NR}$ & $\mathrm{NR}$ & $\mathrm{NR}$ & $\mathrm{NR}$ \\
\hline 4 & 3VA & $\mathrm{NR}$ & NR & $\mathrm{NR}$ & $\mathrm{NR}$ \\
\hline 4 & $4 \mathrm{VA}$ & 697 Down & $378 \mathrm{Up}$ & 33 Down & $\mathrm{NR}$ \\
\hline 5 & 5IVA & $113 \mathrm{Up}$ & 28 Down & $70 \mathrm{Up}$ & $1.69 \mathrm{Up}$ \\
\hline 5 & $52 \mathrm{VA}$ & 287 Down & $134 \mathrm{Up}$ & 189 Down & 1.85 Down \\
\hline 5 & 53VA & 353 Down & $121 \mathrm{Up}$ & 206 Down & 2.15 Down \\
\hline 5 & $54 \mathrm{VA}$ & $\mathrm{NR}$ & $N R$ & $\mathrm{NR}$ & NR \\
\hline 5 & $55 \mathrm{CA}$ & $467 \mathrm{Up}$ & 264 Down & 60 Down & 1.12 Down \\
\hline 5 & 3VA & 669 Down & $474 \mathrm{Up}$ & 36 Down & 0.15 Down \\
\hline 5 & $4 \mathrm{VA}$ & $\mathrm{NR}$ & $\mathrm{NR}$ & $\mathrm{NR}$ & $\mathrm{NR}$ \\
\hline
\end{tabular}

a Toward the structure. 


\begin{tabular}{|c|c|c|c|c|c|c|}
\hline Shot & $\begin{array}{l}\text { Gage } \\
\text { No. }\end{array}$ & $\begin{array}{l}\text { Initial } \\
\text { Peak }\end{array}$ & $\begin{array}{l}\text { Rise } \\
\text { Time } \\
\text { to } \\
\text { Peak }\end{array}$ & $\begin{array}{l}\text { Reflected } \\
\text { Peak }\end{array}$ & $\begin{array}{l}\text { Time of } \\
\text { Reflected } \\
\text { Peak }\end{array}$ & $\begin{array}{l}\text { 100-msec } \\
\text { Level }\end{array}$ \\
\hline & & inches & msec & inches & $\overline{m s e c}$ & inches \\
\hline 1 & $51 \mathrm{HD}$ & 0.06 out & 11 & $0.08 \mathrm{In}$ & 26 & $0.07 \mathrm{In}$ \\
\hline 1 & $52 \mathrm{HD}$ & 0.02 out & 11 & $0.02 \mathrm{In}$ & 26 & $0.02 \mathrm{In}$ \\
\hline 1 & $53 \mathrm{VD}$ & 0.42 out & 17 & 0.42 out & $\mathrm{b}$ & 0.43 out \\
\hline 1 & $54 \mathrm{CD}$ & 0.67 In & 14 & $0.67 \mathrm{In}$ & $\mathrm{b}$ & $0.66 \mathrm{In}$ \\
\hline 2 & $51 \mathrm{HD}$ & 0.16 out & 11 & $0.09 \mathrm{In}$ & 26 & 0.06 out \\
\hline 2 & $52 \mathrm{HD}$ & 0.04 out & 11 & 0.02 In & 26 & 0.05 out \\
\hline 2 & 53VD & 0.65 out & 24 & 0.65 out & $\mathrm{b}$ & 0.59 out \\
\hline 2 & $54 \mathrm{CD}$ & c & c & $c$ & c & c \\
\hline 3 & $51 \mathrm{HD}$ & 0.16 out & 2 & 0.11 In & 22 & $0.11 \mathrm{In}$ \\
\hline 3 & $52 \mathrm{HD}$ & 0.20 out & 2 & $0.22 \mathrm{In}$ & 22 & $0.24 \mathrm{In}$ \\
\hline 3 & 53VD & 0.48 out $^{\mathrm{a}}$ & 20 & d & $\mathrm{b}$ & 0.89 out \\
\hline 3 & $54 \mathrm{CD}$ & $0.66 \mathrm{In} C$ & $c$ & $c$ & c & $c$ \\
\hline 3 & $\mathrm{O} I \mathrm{HD}$ & $0.44 \operatorname{In}^{\mathrm{d}}$ & 16 & $0.44 \operatorname{In}^{\mathrm{d}}$ & 18 & $0.32 \mathrm{In}$ \\
\hline 4 & $5 I H D$ & 0.12 out & 2 & $0.37 \mathrm{In}$ & 38 & $0.27 \mathrm{In}$ \\
\hline 4 & $52 \mathrm{HD}$ & 0.11 out & 2 & $0.36 \mathrm{In}$ & 38 & $0.24 \mathrm{In}$ \\
\hline 4 & 53VD & 0.71 out & 12 & $\mathrm{~b}$ & $\mathrm{~b}$ & 1.12 out \\
\hline 4 & OIHD & $0.15 \operatorname{In} \alpha$ & 16 & $\mathrm{~b}$ & $\mathrm{~b}$ & $0.14 \mathrm{In}$ \\
\hline 5 & $51 \mathrm{HD}$ & 0.16 out & 2 & $0.14 \mathrm{In}$ & $\mathrm{b}$ & $0.07 \mathrm{In}$ \\
\hline 5 & $52 H D$ & 0.11 Out & 2 & $0.21 \mathrm{In}$ & $\mathrm{b}$ & $0.20 \mathrm{In}$ \\
\hline 5 & 53̣VD & 1.52 out $^{\mathrm{d}}$ & 60 & $d$ & $\mathrm{~b}$ & 1.52 Out \\
\hline
\end{tabular}

\footnotetext{
a Time after zero time.

$b$ No single reflection time evident.

c Gage bottomed.

d steady rise to peak.
} 
TARLE A.6 STRAIN GAGE RESURTS

C - Compression, T - Tension, NR - No interpretable recora.

\begin{tabular}{|c|c|c|c|c|c|c|c|c|c|c|c|c|c|c|c|}
\hline $\begin{array}{l}\text { Shot } \\
\text { No. }\end{array}$ & $\begin{array}{l}\text { Gage } \\
\text { No. }\end{array}$ & Location & $\begin{array}{l}\text { Initial } \\
\text { Peak }\end{array}$ & $\begin{array}{l}\text { Rise } \\
\text { Time } \\
\text { to } \\
\text { Peak }\end{array}$ & $\begin{array}{l}\text { Reflected } \\
\text { Peak }\end{array}$ & $\begin{array}{l}\text { Time }{ }^{\mathrm{a}} \text { of } \\
\text { Reflected } \\
\text { Peak }\end{array}$ & $\begin{array}{l}\text { I00-msec } \\
\text { Leve } 1\end{array}$ & $\begin{array}{l}\text { Shot } \\
\text { No. }\end{array}$ & $\begin{array}{l}\text { Gage } \\
\text { No. }\end{array}$ & Loidation & $\begin{array}{l}\text { Initial } \\
\text { Peak }\end{array}$ & $\begin{array}{l}\text { Rise } \\
\text { Time } \\
\text { to } \\
\text { Peak }\end{array}$ & $\begin{array}{l}\text { Reflected } \\
\text { Peak }\end{array}$ & $\begin{array}{l}\text { Time of } \\
\text { Reflected } \\
\text { Peak }\end{array}$ & $\begin{array}{l}\text { 100-msec } \\
\text { Level }\end{array}$ \\
\hline & & degrees & $\mu \mathrm{in} / \mathrm{in}$ & msec & $\mu \mathrm{in} / \mathrm{in}$ & $\mathrm{msec}$ & uin/in & & & degrees & $H$ in/in & msec & $\mu$ ind in & $\mathrm{msec}$ & $\overline{\text { ind }}$ in \\
\hline 1 & IINE & 0 & $303 \mathrm{C}$ & 10 & $343 \mathrm{C}$ & 22 & $120 \mathrm{C}$ & 1 & $612 \mathrm{NE}$ & 30 & NR & $\mathrm{IR}$ & $\mathrm{NR}$ & NR & NR \\
\hline 1 & $12 \mathrm{NE}$ & 0 & 6450 & 7 & 5330 & 20 & 1680 & 1 & $613 \mathrm{NE}$ & 60 & $534 \mathrm{C}$ & 11 & $594 \mathrm{C}$ & 21 & $279 \mathrm{C}$ \\
\hline 1 & $135 E$ & 0 & 4060 & 4 & $426 \mathrm{C}$ & 20 & 1480 & 1 & $614 \mathrm{NE}$ & 60 & $206 \mathrm{c}$ & 1 & $202 \mathrm{C}$ & 24 & $\mathrm{NR}$ \\
\hline 1 & $145 E$ & 0 & $935 \mathrm{~T}$ & 2 & $364 \mathrm{C}$ & 20 & $250 \mathrm{~T}$ & I & $8 \mathrm{INE}$ & 0 & $253 \mathrm{C}$ & 8 & $176 \mathrm{C}$ & 22 & $143 c$ \\
\hline 1 & $15 \mathrm{NE}$ & 10 & $724 \mathrm{C}$ & 10 & 7400 & 23 & 4720 & $\overline{1}$ & $8 \mathrm{CIE}$ & 0 & $1,080 \mathrm{C}$ & 5 & 1,0700 & 23 & $74 \mathrm{C}$ \\
\hline 1 & $16 \mathrm{NE}$ & 10 & $837 \mathrm{~T}$ & 10 & $950 \mathrm{~T}$ & $1 \delta$ & $894 \mathrm{~T}$ & 1 & $83 S 5$ & 0 & $\mathrm{IR}$ & $\mathrm{NR}$ & $\mathrm{NR}$ & $\mathbb{N R}$ & $\mathrm{NR}$ \\
\hline 1 & $19 \mathrm{NE}$ & 20 & $\mathrm{NR}$ & $\mathrm{NR}$ & $\mathrm{IR}$ & IRR & NR & 1 & $84 \mathrm{SE}$ & 0 & $1,997 \mathrm{c}^{\mathrm{b}}$ & 6 & $1,630 c^{b}$ & 21 & $503 c$ \\
\hline 1 & $110 \mathrm{NE}$ & 20 & NR: & NR & NR & TR & $\mathrm{NR}$ & 1 & $85 \mathrm{NE}$ & 20 & $\mathbb{N R}$ & Win & INR & $\mathrm{NR}$ & $\mathrm{NR}$ \\
\hline J. & $113 \mathrm{NE}$ & 30 & $\mathrm{NR}$ & $\mathrm{INR}$ & NR $\quad \mathrm{b}$ & $\mathrm{NR}$ & IVR & 1 & $86 \mathrm{NE}$ & 20 & NR & NR & $\mathrm{NR}$ & $\mathrm{NR}$ & $\mathrm{NR}$ \\
\hline 1 & $114 \mathrm{NE}$ & 30 & $2,630 c^{\mathrm{b}}$ & 13 & $3,370 c^{b}$ & 27 & $3,790 c^{b}$ & 1 & $87 \mathrm{NE}$ & 60 & $\mathrm{NR}$ & $\because \mathrm{R}$ & NR & $\mathrm{NR}$ & $191 \mathrm{C}$ \\
\hline 1 & $115 \mathrm{NE}$ & 60 & $173 \mathrm{C}$ & 10 & 1900 & 23 & 1470 & 1 & $88 \mathrm{NE}$ & 60 & $341 \mathrm{C}$ & 9 & $43 \pi \mathrm{C}$ & 24 & $108 \mathrm{c}$ \\
\hline$I$ & $116 \mathrm{NE}$ & 60 & $1,210 \mathrm{C}$ & 9 & $1,550 \mathrm{C}$ & 21 & $-398 \mathrm{c}$ & 1 & IOINE & 0 & $388 \mathrm{c}$ & 7 & $435 \mathrm{C}$ & 22 & $168 \mathrm{c}$ \\
\hline 1 & 117SE & 60 & $453 \mathrm{C}$ & 8 & $\mathbb{N R}$ & $\mathrm{IRR}$ & $217 \mathrm{C}$ & 1 & $102 \mathrm{NE}$ & 0 & 2290 & 12 & 3000 & 24 & $161 C$ \\
\hline 1 & $318 S E$ & 60 & IT & $\mathbb{R}$ & $\mathrm{INR}$ & $\mathbb{N R}$ & $\mathbb{R} \mathbb{R}$ & I & 103SE & 0 & $147 \mathrm{C}$ & 5 & $2,90 \mathrm{C}$ & 21. & $113 \mathrm{C}$ \\
\hline 1 & $31 N E$ & 0 & IVR & $\mathrm{NR}$ & $\mathrm{NR}$ & IR & $\mathrm{MrR}$ & 1 & $104 \mathrm{SE}$ & 0 & $\mathrm{NR}$ & $\mathrm{HH}$ & $\mathrm{NR}$ & INR & NR \\
\hline 1 & $32 \mathrm{NE}$ & 0 & $238 \mathrm{c}$ & 11 & $206 \mathrm{C}$ & 22 & $29 x$ & 1. & $105 \mathrm{NE}$ & 20 & INR & $\mathrm{NR}$ & IR & NR & $702 c^{b}$ \\
\hline 1 & 4INE & 0 & $205 \mathrm{C}$ & 10 & $391 \mathrm{C}$ & 21 & $120 \mathrm{C}$ & I. & $106 \mathrm{NE}$ & 20 & $\mathbb{I N R}$ & INR & $I R$ & ivR & IR \\
\hline 1 & $42 \mathrm{NE}$ & 0 & $996 \mathrm{C}$ & 6 & 1,0400 & 22 & 1360 & 1 & $107 \mathrm{NE}$ & 60 & $335 \mathrm{c}$ & 6 & $446 \mathrm{C}$ & 21 & I71C \\
\hline 1. & $5 I N E$ & 0 & $357 \mathrm{C}$ & 5 & $364 \mathrm{C}$ & 13 & $188 \mathrm{C}$ & 1 & $108 \mathrm{NE}$ & 60 & $460 \mathrm{c}$ & 3 & $770 C_{b}$ & 23 & $455 c_{h}$ \\
\hline 1. & $52 \mathrm{NE}$ & 0 & $426 \mathrm{c}$ & 3 & $718 \mathrm{c}$ & 24 & $117 \mathrm{C}$ & 1 & $51 \mathrm{IVB}$ & 8 & $10 T^{6}$ & $\mathrm{IR}$ & $10 T^{\circ}$ & 21 & $10 T^{b}$ \\
\hline 1 & 53SE & 0 & 4700 & 5 & 5490 & 21 & 2800 & 1 & $52 \mathrm{NB}$ & 24 & $390 \mathrm{~T}$ & 21 & $310 T$ & 22 & $94 \mathrm{~T}$ \\
\hline 1 & $543 E$ & 0 & 5091 & ź & 2097 & 18 & 340́? & $I$ & $53 \sqrt{1 B}$ & 45 & $519 \mathrm{~T}$ & $11_{4}$ & $552 \mathrm{~T}$ & 27 & $261 \mathrm{~T}$ \\
\hline 1 & $559 \mathrm{E}$ & 89 & $192 \mathrm{C}$ & 4 & $168 \mathrm{c}$ & 21 & 1260 & 1 & $54 \mathrm{TBB}$ & $6 i$ & $317 T$ & 11 & $341 \pi$ & 27 & $237 \mathrm{~T}$ \\
\hline 1 & $56 \mathrm{SE}$ & 89 & $\mathrm{NR}$ & $\mathrm{iR}$ & $\mathrm{ER}$ & $I Q R$ & $\mathrm{NR}$ & 1 & 5 NNB & 83 & $524 T$ & 10 & $566 r$ & 27 & 4029 \\
\hline 1 & $6 \mathrm{LIVE}$ & 0 & $\mathrm{NR}$ & $\sqrt{n}$ & $\mathrm{NR}$ & NR & $\mathrm{RNR}$ & 1 & $56 \mathrm{BB}$ & 45 & 5737 & $\perp$ & $5 \cap 0 \mathrm{~T}$ & 21 & $34 S \mathrm{~T}$ \\
\hline 1 & $62 \mathrm{nE}$ & 0 & $\mathrm{NR}$ & $\mathrm{IRR}$ & $\mathrm{IR}$ & $I R$ & $i R$ & $I$ & OIEX & $7^{c}$ & $25 \times \mathrm{T}$ & 7 & $35 \% T$ & 22 & $198 \mathrm{~T}$ \\
\hline 1 & $635 \mathrm{SE}$ & 0 & $875 \mathrm{C}$ & 12 & $\mathrm{NR}$ & INR & $366 \mathrm{c}$ & 2 & $22 \% C$ & $7^{c}$ & $378 \mathrm{C}$ & 8 & $483 \mathrm{C}$ & 23 & $365 \mathrm{C}$ \\
\hline 1 & $643 E$ & 0 & $60 \mathrm{c}$ & 3 & $204 \mathrm{C}$ & 21 & $72 \mathrm{C}$ & 1 & 23EC & $14.5^{\mathrm{c}}$ & $19 \times 1$ & 8 & $293 \mathrm{~T}$ & 23 & $179 \mathrm{~T}$ \\
\hline 1 & $65 \mathrm{NE}$ & 10 & $I, 360 \mathrm{C}$ & 7 & 1,2100 & 20 & $236 \mathrm{c}$ & 1 & $24 \mathrm{WC}$ & $14.5^{\mathrm{c}}$ & 3300 & 8 & $480 \mathrm{C}$ & 22 & 2600 \\
\hline I & $66 \mathrm{NE}$ & 10 & IIR & $\ln \bar{R}$ & $\mathrm{ITR}$ & IN & $1,070 c^{b}$ & & & & & & & & \\
\hline$I$ & $67 N E$ & 20 & $I R$ & $\operatorname{lin}$ & in & $\mathrm{iR}$ & $870 r^{b}$ & 2 & ILVE & $\mathrm{c}$ & $4+\pi$ & 2 & $345 \mathrm{C}$ & 16 & $24 c^{b}$ \\
\hline 1 & $68 \mathrm{NE}$ & 20 & $\mathbb{N R}$ & $\mathbb{N R}$ & $\mathrm{JTR}$ & 泟 & $\mathrm{INR}$ & 2 & $1 \Omega \mathrm{NE}$ & 0 & $990 \mathrm{C}$ & 3 & 1,2800 & 20 & $108 \mathrm{C}$ \\
\hline 1 & 69SE & 20 & $\mathrm{INR}$ & IN $\mathrm{K}$ & NR & $n i 2$ & 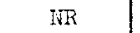 & a & $13 \mathrm{EE}$ & 0 & $574 \mathrm{C}$ & 2 & 4750 & Is & $119 \mathrm{c}$ \\
\hline 1 & 61052 & 20 & $\mathrm{MR}$ & IVR & $i V R$ & $\mathrm{TR}$ & $I R R$ & 2 & $143 \mathrm{E}$ & 0 & $\mathrm{IR}$ & $\mathrm{HB}$ & IF & in & in \\
\hline 1. & 611NE & 30 & $843 c^{b}$ & 12 & $42 c^{\circ}$ & 23 & $724 c^{b}$ & 2 & $I 5 N E$ & 10 & $8+5 \mathrm{C}$ & $c$ & 8270 & 19 & $457 \mathrm{C}$ \\
\hline
\end{tabular}

$\mathrm{a}$ Time after zero time.

Questionable result.

Inches above the truss-bulkhead beam connecting bolt center. 
TABLE A.6 (CONTINUED)

\begin{tabular}{|c|c|c|c|c|c|c|c|c|c|c|c|c|c|c|c|}
\hline $\begin{array}{l}\text { Shot } \\
\text { No. }\end{array}$ & $\begin{array}{l}\text { Gage } \\
\text { No. }\end{array}$ & Iocation & $\begin{array}{l}\text { Initial } \\
\text { Peak }\end{array}$ & $\begin{array}{l}\text { Rise } \\
\text { Time } \\
\text { to } \\
\text { Peak }\end{array}$ & $\begin{array}{l}\text { Reflected } \\
\text { Peak }\end{array}$ & $\begin{array}{l}\text { Time of } \\
\text { Reflected } \\
\text { Peak }\end{array}$ & $\begin{array}{l}100 \text {-msec } \\
\text { Level }\end{array}$ & $\begin{array}{l}\text { Shot } \\
\text { No. }\end{array}$ & $\begin{array}{l}\text { Gage } \\
\text { No. }\end{array}$ & Iocation & $\begin{array}{l}\text { Initial } \\
\text { Peak }\end{array}$ & $\begin{array}{l}\text { Rise } \\
\text { Time } \\
\text { to } \\
\text { Peak }\end{array}$ & $\begin{array}{l}\text { Reflected } \\
\text { Peak }\end{array}$ & $\begin{array}{l}\text { Time of } \\
\text { Reflected } \\
\text { Peak }\end{array}$ & $\begin{array}{l}\text { loo-msec } \\
\text { Level }\end{array}$ \\
\hline & & degrees & $\mu$ in/in & msec & Hin/in & $\overline{\mathrm{msec}}$ & Hin/in & & & degrees & $\mu$ in/in & msec & $\mu$ in $/$ in & $\mathrm{msec}$ & $\mu$ in/in \\
\hline 2 & $16 \mathrm{NE}$ & 10 & $357 \mathrm{~T}$ & 5 & $243 \mathrm{~T}$ & 19 & $515 \mathrm{~T}$ & 2 & 83SE & 0 & $257 \mathrm{C}$ & 5 & 6390 & 19 & $356 \mathrm{C}$ \\
\hline 2 & $19 \mathrm{NE}$ & 20 & $1,014 \mathrm{C}$ & 5 & $894 \mathrm{C}$ & 19 & $1,220 \mathrm{C}$ & 2 & $8 L_{S E}$ & 0 & $1,850 \mathrm{C}$ & 3 & 1,1000 & 17 & $256 \mathrm{~T}$ \\
\hline 2 & $110 \mathrm{NE}$ & 20 & $\mathrm{IVR}$ & IVR & $\mathrm{NR}$ & INR & $N R$ & 2 & $85 \mathrm{NE}$ & 20 & $1,130 \mathrm{C}$ & 10 & $1,340 \mathrm{C}$ & 20 & $1,230 \mathrm{C}$ \\
\hline 2 & $113 \mathrm{kF}$ & 30 & 1,0900 & 8 & $1,270 \mathrm{C}$ & 19 & $1,1,50 \mathrm{C}$ & 2 & $86 \mathrm{NE}$ & 20 & $\mathrm{NR}$ & $\mathrm{NR}$ & $\mathrm{NR}$ & NR & $\mathrm{NR}$ \\
\hline 2 & $114 \mathrm{IVE}$ & 30 & $\mathrm{NR}$ & $\mathbb{R R}$ & $\mathrm{MR}$ & INR & $\mathrm{NR}$ & 2 & $871: E$ & 60 & $685 c$ & 7 & $857 \mathrm{C}$ & 20 & $537 \mathrm{C}$ \\
\hline 2 & $115 \mathrm{NE}$ & 60 & $571 \mathrm{C}$ & 7 & $687 \mathrm{C}$ & 19 & $5 \mathrm{CHC}$ & 2 & $88 \mathrm{NE}$ & 60 & $441 \mathrm{C}$ & 3 & $403 C$ & 19 & $671 T$ \\
\hline 2 & $116 \mathrm{NE}$ & 60 & $796 \mathrm{C}$ & 3 & $816 \mathrm{c}$ & 20 & $\mathbb{I N R}$ & 2 & $101 \mathrm{HE}$ & 0 & $634 \mathrm{C}$ & 7 & $866 \mathrm{c}$ & 20 & 4330 \\
\hline 2 & $117 \mathrm{SE}$ & 60 & $571 \mathrm{C}$ & 8 & 7290 & 19 & $532 \mathrm{C}$ & 2 & $102 \mathrm{NE}$ & 0 & $370 \mathrm{~T}$ & 2 & $520 T$ & 20 & $458 \mathrm{~T}$ \\
\hline 2 & $118 \mathrm{SE}$ & 60 & $\mathrm{NR}$ & $\operatorname{IrR}$ & $\mathrm{NR}$ & $\mathrm{MR}$ & $\mathrm{NF}$ & 2 & IOZSE & 0 & $413 \mathrm{C}$ & 5 & $698 \mathrm{c}$ & 19 & $413 \mathrm{C}$ \\
\hline 2 & $3 \mathrm{INE}$ & 0 & $\mathrm{INR}$ & IVR & $\sqrt{R}$ & IR & $\mathrm{Mr}$ & 2 & $104 \mathrm{SE}$ & 0 & $991 \mathrm{C}$ & 3 & $913 \mathrm{C}$ & 16 & $N R$ \\
\hline 2 & $32 \mathrm{NE}$ & 0 & IR & $\mathrm{INR}$ & $\mathrm{NR}$ & $I R$ & MN & 2 & $1051 \mathrm{VE}$ & 20 & 1,0400 & 7 & 1,3400 & 19 & $783 \mathrm{C}$ \\
\hline 2 & 4INE & 0 & $336 \mathrm{c}$ & 3 & $383 \mathrm{C}$ & 20 & 2690 & 2 & $106 \mathrm{NE}$ & 20 & $\mathrm{NR}$ & NR & NR & NR & $\mathrm{IR}$ \\
\hline 2 & 42IVE & 0 & $\mathbb{N R}$ & $\mathrm{WR}$ & $\mathbb{N R}$ & NR & in & 2 & $107 \mathrm{NE}$ & 60 & 5400 & 5 & $675 \mathrm{c}$ & 19 & $398 \mathrm{c}$ \\
\hline 2 & $5 \amalg E$ & 0 & 4900 & 2 & 4690 & 19 & $323 \mathrm{C}$ & 2 & $108 \mathrm{NE}$ & 60 & $\mathrm{NR}$ & IR & INR & $\mathrm{IR}$ & $\mathrm{NR}$ \\
\hline 2 & $52 \mathrm{NE}$ & 0 & $852 \mathrm{C}$ & 5 & $1,030 \mathrm{C}$ & 18 & $398 \mathrm{~T}$ & 2 & $51 \mathrm{NB}$ & 8 & $194 \mathrm{~T}$ & 8 & $268 \mathrm{~T}$ & 17 & $48 T$ \\
\hline 2 & $53 \mathrm{SE}$ & 0 & $5,58 \mathrm{C}$ & 3 & $818 \mathrm{c}$ & 19 & $391 \mathrm{C}$ & 2 & $52 \mathrm{NB}$ & 24 & $5,98 \mathrm{~T}$ & 8 & $472 T$ & 20 & $105 \mathrm{C}$ \\
\hline 2 & $545 E$ & 0 & $333 \mathrm{C}$ & 5 & $9 T$ & 17 & $582 \mathrm{~T}$ & 2 & $53 \mathrm{NB}$ & 45 & $790 \mathrm{~T}$ & 8 & $778 \pi$ & 19 & $271 \mathrm{~T}$ \\
\hline 2 & $55 \mathrm{SE}$ & 89 & $257 \mathrm{C}$ & 4 & $170 \mathrm{C}$ & 19 & ล̇I & 2 & $5,4 \mathrm{NB}$ & 67 & $607 \mathrm{~T}$ & 8 & $660 \mathrm{~T}$ & 19 & $456 \mathrm{~m}$ \\
\hline 2 & $56 \mathrm{SE}$ & 89 & $\operatorname{In}$ & INR & $\mathrm{NR}$ & $\mathrm{MR}$ & IN & 2 & $55 \mathrm{NB}$ & 83 & $663 \mathrm{~T}$ & 7 & $719 T$ & 18 & $497 \%$ \\
\hline 2 & 6INE & 0 & $\mathrm{IFR}$ & $\mathrm{NR}$ & $\mathrm{NR}$ & $\mathrm{NR}$ & $\mathrm{NR}$ & 2 & $56 \mathrm{sB}$ & 45 & $900 \mathrm{~T}$ & $\varepsilon$ & $873 T$ & 18 & $343 T$ \\
\hline 2 & $62 \mathrm{NE}$ & 0 & 1,2600 & 6 & 1,1700 & 19 & 0 & 2 & $2 I E C$ & $7^{c}$ & $371 \mathrm{~T}$ & 3 & $540 \mathrm{~T}$ & 19 & $287 T$ \\
\hline 2 & $635 E$ & 0 & $361 \mathrm{C}$ & 4 & $647 \mathrm{C}$ & 20 & $222 \mathrm{C}$ & 2 & $22 \mathrm{WC}$ & $7^{\mathrm{c}}$ & 5200 & 6 & 6720 & 20 & $396 \mathrm{C}$ \\
\hline 2 & $64 \mathrm{SE}$ & 0 & $1,370 \mathrm{C}$ & 4 & $825 \mathrm{C}$ & 18 & 1800 & 2 & $23 \mathrm{EC}$ & $14.5^{\mathrm{c}}$ & $166 \mathrm{~m}$ & 2 & 25RT & 20 & $231 \mathrm{~T}$ \\
\hline 2 & $65 \mathrm{NE}$ & 10 & 1,1600 & 8 & $1,270 \mathrm{C}$ & 20 & 6490 & 2 & $24 w C$ & $14.5^{\mathrm{c}}$ & $504 \mathrm{C}$ & 7 & $628 \mathrm{C}$ & 20 & $395 \mathrm{C}$ \\
\hline 2 & $66 \mathrm{NE}$ & 10 & $1,44 \mathrm{OT}$ & 6 & $1,760 \mathrm{~T}$ & 20 & $\mathrm{NR}$ & & & & & & & & \\
\hline 2 & $6 \mathrm{TNE}$ & 20 & $1,460 \mathrm{C}$ & 9 & $1,750 \mathrm{C}$ & 20 & $1,500 \mathrm{C}$ & 3 & ITNE & 0 & $1,130 \mathrm{C}$ & 6 & $1,160 c_{h}$ & 18 & $784 \mathrm{C}_{\mathrm{h}}$ \\
\hline 2 & 68rie & 20 & $2,760 \mathrm{~T}$ & 9 & $3,86 \mathrm{~cm}$ & 21 & $620 T$ & 3 & $12 \mathrm{NE}$ & 0 & $1,170 \mathrm{C}$ & 3 & $100 \mathrm{~T}^{\mathrm{b}}$ & 18 & $1,250 \mathrm{~T}^{\mathrm{D}}$ \\
\hline 2 & 6955 & 20 & 1,2200 & 7 & $1,580 \mathrm{C}$ & 20 & $1,75 x$ & 3 & $15 \mathrm{NE}$ & 60 & 1,3400 & 8 & $1,740 \mathrm{C}$ & 18 & $1,24,0 \mathrm{C}$ \\
\hline 2 & $6105 E$ & 20 & INR & NR & $\mathrm{NR}$ & NR & ITR & 3 & $16 \mathrm{NE}$ & 60 & 1,0200 & 2 & 0 & 18 & $1,320 \mathrm{~T}$ \\
\hline 2 & GIINE & 30 & $1,14 \mathrm{OC}$ & 6 & 1,4300 & 19 & 1,7000 & 3 & $17 \mathrm{SE}$ & 0 & $1,170 \mathrm{C}$ & 4 & $928 \mathrm{C}$ & 17 & $538 \mathrm{c}$ \\
\hline 2 & $612 \mathrm{NE}$ & 30 & $I R$ & IiR & $\mathrm{IR}$ & $\mathrm{NR}$ & IR & 3 & $18 \mathrm{SE}$ & 0 & $602 \mathrm{~T}^{\mathrm{b}}$ & 3 & $\mathrm{INR}$ & NR & IVR $\mathrm{b}$ \\
\hline 2 & 613NE & 60 & $759 \mathrm{C}$ & 8 & $94 \mathrm{IC}$ & 20 & $581 \mathrm{C}$ & 3 & $21 \mathrm{NE}$ & 0 & $253 \mathrm{C}^{\mathrm{b}}$ & 5 & $327 \mathrm{c}^{\mathrm{b}}$ & 17 & $285 \mathrm{c}^{\circ}$ \\
\hline $\bar{c}$ & $614 \mathrm{NE}$ & 60 & IR & $\mathrm{IRR}$ & $I R$ & $\mathrm{FR}$ & $\mathrm{NR}$ & 3 & $22 \mathrm{NE}$ & 0 & $2,870 \mathrm{C}$ & 3 & d & d & 9290 \\
\hline 2 & BWYE & 0 & 3110 & 8 & $436 \mathrm{C}$ & 20 & $321 \mathrm{C}$ & 3 & $23 S E$ & 20 & 9000 & $\epsilon$ & $1,110 \mathrm{C}$ & 17 & $1,110 \mathrm{C}$ \\
\hline 2 & $82 N E$ & 0 & $1,210 \mathrm{C}$ & 3 & $872 \mathrm{C}$ & 19 & $\begin{array}{c}284 \mathrm{~T} \\
\text { (Cont }\end{array}$ & inued) & $24 \mathrm{SE}$ & 20 & $\mathrm{INR}$ & $\mathbb{N R}$ & $\mathbb{N R}$ & INR & IN \\
\hline
\end{tabular}

b Questionable result.

c Inches above the truss-bulkhead beam connecting bolt center.

(2 o: 14 sheets)

d No reflection apparent. 
TABLE A.6 (CONTINUED)

\begin{tabular}{|c|c|c|c|c|c|c|c|c|c|c|c|c|c|c|c|}
\hline $\begin{array}{l}\text { Shot } \\
\text { No. }\end{array}$ & $\begin{array}{l}\text { Gage } \\
\text { No. }\end{array}$ & Iocation & $\begin{array}{l}\text { Initial } \\
\text { Peak }\end{array}$ & $\begin{array}{l}\text { Rise } \\
\text { Time } \\
\text { to } \\
\text { Peak }\end{array}$ & $\begin{array}{l}\text { Reflected } \\
\text { Peak }\end{array}$ & $\begin{array}{l}\text { Time of } \\
\text { Reflected } \\
\text { Peak }\end{array}$ & $\begin{array}{l}\text { 100-msec } \\
\text { Irevel }\end{array}$ & $\begin{array}{l}\text { Shot } \\
\text { No. }\end{array}$ & $\begin{array}{l}\text { Gage } \\
\text { No. }\end{array}$ & Iocation & $\begin{array}{l}\text { Initial } \\
\text { Peak }\end{array}$ & $\begin{array}{l}\text { Rise } \\
\text { Time } \\
\text { to } \\
\text { Peak }\end{array}$ & $\begin{array}{l}\text { Reflected } \\
\text { Peak }\end{array}$ & $\begin{array}{l}\text { Time of } \\
\text { Reflected } \\
\text { Peak }\end{array}$ & $\begin{array}{l}\text { 100-msec } \\
\text { Level }\end{array}$ \\
\hline & & degrces & $\mu i n / i n$ & msec & $\mu$ in/in & msec & uin/in & & & degrees & win $/$ in & $\mathrm{msec}$ & min/in & $\mathrm{msec}$ & in/in \\
\hline 3 & $3 \mathrm{INE}$ & 0 & $\mathrm{NR}$ & $\mathrm{NR}$ & $\mathrm{NR}$ & $\mathrm{INR}$ & $\mathbb{N R}$ & 3 & $72 \mathrm{NE}$ & 0 & 6700 & 1 & $1,060 \mathrm{c}$ & 17 & $350 \mathrm{~T}$ \\
\hline 3 & $32 \mathrm{NE}$ & 0 & $\mathrm{NR}$ & $\mathbb{N R}$ & $\mathrm{INR}$ & $\mathbb{N R}$ & IRR & 3 & $8 \backsim \mathrm{NE}$ & 0 & 1,1500 & 6 & $718 \mathrm{C}$ & 18 & $495 \mathrm{C}$ \\
\hline 3 & $33 \mathrm{NG}$ & 10 & $800 \mathrm{C}$ & I & $799 \mathrm{C}$ & 16 & $452 \mathrm{C}$ & 3 & $82 \mathrm{NE}$ & 0 & $840 c$ & 4 & $1,400 \mathrm{C}$ & 17 & $50 \mathrm{~T}$ \\
\hline 3 & $3^{4}+\mathrm{NE}$ & 10 & $1,560 \mathrm{C}$ & 2 & $700 \mathrm{c}$ & 17 & $1,290 \mathrm{~T}$ & 3 & $91 \mathrm{NE}$ & 0 & $375 \mathrm{C}$ & 4 & $198 \mathrm{C}$ & 18 & 3100 \\
\hline 3 & $35 \mathrm{NE}$ & 20 & $1,180 \mathrm{C}$ & 6 & $1,280 \mathrm{C}$ & 16 & 1,1100 & 3 & $9 \subset \mathrm{NE}$ & 0 & $\mathrm{NR}$ & $\mathrm{NR}$ & $\mathrm{NR}$ & $\mathrm{NR}$ & $\mathrm{NR}$ \\
\hline 3 & $36 \mathrm{rEE}$ & 20 & $1,500 \mathrm{r}$ & 1 & $970 \mathrm{~T}$ & 18 & $2,910 \mathrm{~T}$ & 3 & 101NE & 0 & $820 \mathrm{c}$ & 6 & $835 \mathrm{C}$ & 18 & $456 \mathrm{C}$ \\
\hline 3 & $37 \mathrm{NE}$ & 30 & $1,620 \mathrm{C}$ & 7 & 2,2000 & 18 & $2,300 \mathrm{C}$ & 3 & $102 \mathrm{NE}$ & 0 & 1,2400 & 4 & 1,1500 & 18 & $970 \mathrm{C}$ \\
\hline 3 & $38 \mathrm{NE}$ & 30 & $\mathrm{IR}$ & $\mathrm{NR}$ & $\mathrm{IRR}$ & $\mathbb{N R}$ & $\mathrm{NR}$ & 3 & $51 \mathrm{NB}$ & 8 & $854 \mathrm{~T}$ & 4 & $680 \mathrm{~T}$ & 18 & $102 T$ \\
\hline 3 & $39 \mathrm{FE}$ & 60 & $1,210 \mathrm{C}$ & 6 & $1,370 \mathrm{C}$ & 18 & $768 \mathrm{C}$ & 3 & $52 \mathrm{NB}$ & 24 & $1,530 \mathrm{~T}$ & 7 & $1,510 \mathrm{~T}$ & 18 & $438 \mathrm{~T}$ \\
\hline 3 & $310 N E$ & 60 & $\mathrm{NR}$ & $\mathrm{IRR}$ & INR & INR & $I R$ & 3 & $53 \mathrm{NB}$ & 45 & $N R$ & $\mathbb{N R}$ & $\mathrm{NR}$ & $\mathrm{NR}$ & $\mathrm{NR}$ \\
\hline 3 & 3IISE & 0 & $1,220 \mathrm{C}$ & 6 & $867 \mathrm{C}$ & 17 & 1990 & 3 & $54 \mathrm{NB}$ & 67 & INR & $\mathrm{ITR}$ & $\mathrm{IRR}$ & $\mathrm{IR}$ & $\mathrm{NR}$ \\
\hline 3 & $312 S E$ & 0 & $\mathrm{IRR}$ & $\mathrm{NR}$ & $\mathrm{IR}$ & $\mathbb{N R}$ & $\mathrm{IRR}$ & 3 & $5 \mathrm{gNB}$ & 83 & $995 \mathrm{~T}$ & 9 & d & d & $634 \mathrm{~T}$ \\
\hline 3 & 4]NE & 0 & $\mathrm{NR}$ & $\mathrm{INR}$ & $\mathrm{AR}$ & $\mathbb{N R}$ & $\mathbb{N R}$ & 3 & $56 \mathrm{SB}$ & 45 & $1,340 \mathrm{~T}$ & 9 & $1,190 \mathrm{~T}$ & 18 & $533 \mathrm{~T}$ \\
\hline 3 & $42 \mathrm{NE}$ & 0 & $\mathrm{RR}$ & $\mathrm{NR}$ & IVR & $\mathrm{NR}$ & $1,170 \mathrm{C}$ & 3 & 2IEC & $\tau$ & $689 \mathrm{~T}$ & 5 & $943 \mathrm{~T}$ & 18 & $509 \mathrm{~T}$ \\
\hline 3 & $43 \mathrm{NE}$ & 20 & $1,330 \mathrm{C}$ & 6 & 1,5600 & 17 & $I, 560 \mathrm{C}$ & 3 & $22 \mathrm{WC}$ & $7^{c}$ & $758 \mathrm{c}$ & 5 & $1,050 \mathrm{C}$ & 18 & $469 \mathrm{c}$ \\
\hline 3 & $44 \mathrm{NE}$ & 20 & $1,550 \mathrm{~T}$ & 1 & d & d & 4,150T & 3 & 23EC & $14.5^{c}$ & $626 \mathrm{~T}$ & 5 & $923 T$ & 18 & $446 \mathrm{~T}$ \\
\hline 3 & $45 \mathrm{NE}$ & 60 & 1,4700 & 8 & $1,470 \mathrm{C}$ & 18 & 1,0100 & 3 & $24 \mathrm{WC}$ & $14.5^{\mathrm{c}}$ & 8700 & 5 & $1,410 \mathrm{C}$ & 18 & $990 \mathrm{C}$ \\
\hline 3 & $46 \mathrm{NE}$ & 60 & 1,5700 & 3 & $250 \mathrm{C}$ & .28 & $1,710 \mathrm{~T}$ & 4 & IINE & 0 & $780 \mathrm{c}$ & 3 & $451 \mathrm{C}$ & 17 & $472 \mathrm{C}$ \\
\hline 3 & $5 \mathrm{HNE}$ & 0 & $400 \mathrm{C}$ & 2 & 4200 & 18 & $308 \mathrm{C}$ & 4 & IOHE & 0 & 1,1300 & 6 & $1,690 \mathrm{c}$ & 19 & $708 \mathrm{C}$ \\
\hline 3 & $52 \mathrm{NE}$ & 0 & $1,800 \mathrm{C}$ & 4 & $\mathrm{NR}$ & $\mathrm{ITR}$ & $\mathrm{IR}$ & 4 & 2LIVE & 0 & 1,1300 & 4 & $863 \mathrm{C}$ & 19 & $454 \mathrm{C}$ \\
\hline 3 & $53 \mathrm{NE}$ & 10 & $1,450 \mathrm{C}$ & 6 & $1,450 \mathrm{C}$ & 18 & $922 \mathrm{C}$ & 4 & 2eNs & 0 & $1,520 \mathrm{C}$ & 11 & e & e & $280 \mathrm{c}$ \\
\hline 3 & $54 \mathrm{IEE}$ & 10 & $860 \mathrm{c}$ & 3 & $1,300 \mathrm{~T}$ & 18 & $I 5,500 \mathrm{~T}$ & 4 & $4 I N E$ & 0 & $1,180 \mathrm{C}$ & 5 & 4800 & 18 & $88 \mathrm{~T}$ \\
\hline 3 & $55 \mathrm{NE}$ & 20 & $1,560 \mathrm{C}$ & 6 & 1,9600 & 18 & $2,150 \mathrm{C}$ & 4 & $42 \mathrm{NE}$ & 0 & $1,060 \mathrm{C}$ & 5 & $1,300 \mathrm{C}$ & 20 & $345 \mathrm{C}$ \\
\hline 3 & $56 \mathrm{NE}$ & 20 & $1,550 \mathrm{~T}$ & 4 & $2,700 \mathrm{~s}$ & 18 & IVR & 4 & $5 \mathrm{INE}$ & 0 & $1,040 \mathrm{C}$ & 4 & $677 \mathrm{C}$ & 17 & $190 \mathrm{C}$ \\
\hline 3 & $57 N E$ & 30 & $1,930 \mathrm{c}$ & 8 & 2,5400 & 18 & $4,980 \mathrm{C}$ & 4 & 52NE & 0 & $1,350 \mathrm{C}$ & 5 & e & e & $270 \mathrm{C}$ \\
\hline 3 & $58 \mathrm{NE}$ & 30 & $2,950 \mathrm{C}$ & 10 & 5,2000 & 28 & 10,8700 & 4 & $53 \sqrt{E}$ & 30 & 1,1900 & 6 & $1,690 \mathrm{C}$ & 18 & $2,650 c$ \\
\hline 3 & $59 \mathrm{NE}$ & 60 & $1,360 \mathrm{C}$ & 8 & 1,4600 & 18 & 7900 & 4 & $54 \mathrm{NNE}$ & 30 & 2,4800 & 4 & e & $\mathrm{e}$ & 5,5700 \\
\hline$\overline{3}$ & $510 \mathrm{NE}$ & 60 & $778 \mathrm{C}$ & 1 & 200 & 18 & $704 \mathrm{~T}$ & 4 & $55 \mathrm{NE}$ & 45 & 1,2200 & 8 & $1,370 \mathrm{C}$ & 18 & $1,1_{4}, 40 \mathrm{C}$ \\
\hline 3 & 5IISE & 60 & $1,370 \mathrm{C}$ & 8 & 1,6100 & 18 & $768 \mathrm{C}$ & 4 & $56 \mathrm{NE}$ & 45 & $\mathrm{NR}$ & $\mathrm{NR}$ & $\mathrm{NR}$ & $\mathrm{IR}$ & IRR \\
\hline 3 & $5125 \mathrm{E}$ & 60 & $835 \mathrm{C}$ & 3 & $70 \mathrm{~T}$ & 18 & $487 \mathrm{~T}$ & 4 & $57 \mathrm{NE}$ & 60 & $703 \mathrm{C}$ & 3 & 1,4900 & 17 & INR \\
\hline 3 & 513SE & 20 & $3,010 \mathrm{C}$ & 10 & $3,440 \mathrm{C}$ & 16 & $4,040 \mathrm{C}$ & 4 & $58 \mathrm{NE}$ & 60 & $504 \mathrm{C}$ & 3 & $168 \mathrm{C}$ & 17 & $1,850 \mathrm{C}$ \\
\hline 3 & $514 \mathrm{SE}$ & 20 & $4,720 T$ & 4 & $\mathrm{IR}$ & $\mathrm{NR}$ & $\mathbb{N R}$ & 4 & $50 \mathrm{NE}$ & 75 & 1,2000 & 3 & 1,2000 & 18 & $194 \mathrm{~T}$ \\
\hline 3 & 515SE & 0 & $1,260 \mathrm{C}$ & 6 & 9300 & 18 & $136 \mathrm{C}$ & 4 & $510 \mathrm{NE}$ & 75 & $\mathrm{IRR}$ & IIR & $\ln$ & $\mathrm{NR}$ & $\mathbb{I R}$ \\
\hline 3 & $516 \mathrm{SE}$ & 0 & $1,400 \mathrm{C}$ & 4 & 5390 & 18 & 0 & 4 & $511 \mathrm{SE}$ & 60 & $1,210 \mathrm{C}$ & 7 & 1,5200 & 19 & $774 \mathrm{C}$ \\
\hline 3 & $71 \mathrm{NE}$ & 0 & $1,390 \mathrm{c}$ & 6 & $646 \mathrm{c}$ & 17 & $495 \mathrm{C}$ & 4 & $5128 \mathrm{E}$ & 60 & $813 \mathrm{C}$ & 2 & $529 \mathrm{~T}$ & 22 & $150 \mathrm{~T}$ \\
\hline \multicolumn{16}{|c|}{ (Continued) } \\
\hline
\end{tabular}

d Inches above the truss-bulkhead beam connecting bolt center.

(3 of 4 sheets)

No reflection apparent. 
TABLE A.6 (CONCLUDED)

\begin{tabular}{|c|c|c|c|c|c|c|c|c|c|c|c|c|c|c|c|}
\hline $\begin{array}{l}\text { Shot } \\
\text { No. }\end{array}$ & $\begin{array}{l}\text { Gage } \\
\text { No. }\end{array}$ & Location & $\begin{array}{l}\text { Initial } \\
\text { Peat }\end{array}$ & $\begin{array}{l}\text { Rise } \\
\text { Time } \\
\text { to } \\
\text { Peak }\end{array}$ & $\begin{array}{l}\text { Reflected } \\
\text { Peak }\end{array}$ & $\begin{array}{l}\text { Time of } \\
\text { Rerlected } \\
\text { Peak }\end{array}$ & $\begin{array}{l}\text { loo-msec } \\
\text { Level }\end{array}$ & $\begin{array}{l}\text { Shot } \\
\text { No. }\end{array}$ & $\begin{array}{l}\text { Gage } \\
\text { No. }\end{array}$ & Location & $\begin{array}{l}\text { Initial } \\
\text { Peak }\end{array}$ & $\begin{array}{l}\text { Rise } \\
\text { Time } \\
\text { to } \\
\text { Peak }\end{array}$ & $\begin{array}{l}\text { Reflected } \\
\text { Peak }\end{array}$ & $\begin{array}{l}\text { Time of } \\
\text { Reflected } \\
\text { Peak }\end{array}$ & $\begin{array}{l}\text { 100-msec } \\
\text { Level }\end{array}$ \\
\hline & & degrees & $\mu$ in/in & msec & $\mu$ in/in & msec & Hindin & & & degrees & Hin/in & msec & $\mu$ in/in & msec & Hin/in \\
\hline 4 & $5135 E$ & 45 & $\operatorname{IR}$ & $\mathrm{NR}$ & $\mathrm{NR}$ & $\mathrm{IRR}$ & $\mathrm{IR}$ & 4 & $52 \mathrm{NB}$ & 24 & $915 \mathrm{~T}$ & 8 & $1,330 \mathrm{~T}$ & 18 & $348 \mathrm{~T}$ \\
\hline 4 & $514 \mathrm{SE}$ & 45 & $1,810 \mathrm{~T}$ & 9 & e & e & $6,120 \mathrm{~T}$ & 4 & $53 \mathrm{NB}$ & 45 & $855 T$ & 8 & $1,04 \mathrm{CT}$ & 18 & $315 \mathrm{~T}$ \\
\hline 4 & $5 I 5 \mathrm{SE}$ & 30 & 2,2000 & 9 & $4,060 \mathrm{C}$ & 19 & 7,4200 & 4 & $54 \mathrm{NB}$ & 67 & $810 \mathrm{~T}$ & 8 & $838 \mathrm{~T}$ & 18 & $351 \mathrm{~T}$ \\
\hline 4 & $5165 E$ & 30 & $3,180 \mathrm{~T}$ & 10 & e & $\mathrm{e}$ & $23,500 \mathrm{~T}$ & 4 & $55 \mathrm{NB}$ & 83 & $952 \mathrm{~T}$ & 8 & $899 \mathrm{~T}$ & 19 & $449 \mathrm{~T}$ \\
\hline 4 & $517 \mathrm{TE}$ & 20 & $914 \mathrm{C}$ & 3 & $637 c$ & 18 & 3320 & 4 & $56 \mathrm{SB}$ & 45 & $1,380 \mathrm{~T}$ & 8 & $1,480 \mathrm{~T}$ & 18 & $647 \mathrm{~T}$ \\
\hline 4 & $51 \mathrm{NE}$ & 20 & 1,6700 & 9 & $\mathrm{e}$ & $\mathrm{e}$ & $618 \mathrm{c}$ & 4 & $23 \mathrm{EC}$ & $7_{s}^{\mathrm{c}}$ & $843 \mathrm{~T}$ & 5 & $1,100 \mathrm{~T}$ & 18 & $748 \mathrm{~T}$ \\
\hline 4 & 6135 & 0 & $807 \mathrm{C}$ & 4 & $690 \mathrm{C}$ & 17 & $154 \mathrm{C}$ & 4 & $22 \mathrm{wC}$ & $7^{\mathrm{c}}$ & $842 \mathrm{C}$ & 6 & $924 \mathrm{C}$ & 18 & $408 \mathrm{C}$ \\
\hline 4 & $62 \mathrm{NE}$ & 0 & $628 \mathrm{c}$ & 2 & $\mathbb{N R}$ & IIR & $\mathrm{NR}$ & 4 & $23 \mathrm{EC}$ & $14.5^{c}$ & $818 \mathrm{~T}$ & 6 & $1,020 \mathrm{~T}$ & 18 & $780 \mathrm{~T}$ \\
\hline 4 & $8 \mathrm{INE}$ & 0 & $737 \mathrm{C}$ & 9 & $853 C$ & 18 & $446 \mathrm{c}$ & 4 & $24 \mathrm{WC}$ & $14.5^{c}$ & $950 \mathrm{C}$ & 6 & $1,200 \mathrm{C}$ & 18 & $502 \mathrm{C}$ \\
\hline 4 & $82 \mathrm{NE}$ & 0 & $\mathrm{IR}$ & $\mathrm{NR}$ & $\mathrm{NR}$ & $\mathrm{INR}$ & $\mathbb{N R}$ & 5 & $1] N E$ & 0 & 6900 & $f$ & $\mathrm{NR}$ & $\mathrm{NR}$ & $\mathrm{NR}$ \\
\hline 4 & $83 \mathrm{INE}$ & 30 & $2,330 \mathrm{C}$ & 7 & 4,8800 & 20 & $5,320 \mathrm{c}$ & 5 & $12 \mathrm{IE}$ & a & $\mathrm{NR}$ & $f$ & $\mathrm{NR}$ & $\mathrm{NR}$ & $\mathbb{N R}$ \\
\hline 4 & $84 \mathrm{NE}$ & 30 & e & $e$ & e & $\mathrm{e}$ & $11,200 \mathrm{~T}$ & 5 & 2INE & 0 & $1,060 \mathrm{C}$ & $f$ & 6120 & 17 & $237 T$ \\
\hline 4 & $85 \mathrm{NE}$ & 45 & 1,0300 & 7 & 1,3300 & 19 & 1,3800 & 5 & $221 \mathrm{LE}$ & 9 & 3,4900 & $\mathrm{f}$ & $3,530 \mathrm{C}$ & 19 & $2,660 \mathrm{C}$ \\
\hline 4 & $86 \mathrm{NE}$ & 45 & $\mathrm{NR}$ & In & $\mathrm{NR}$ & $\mathrm{I} / \mathrm{R}$ & INR & 5 & 3INE & 0 & 9500 & $\mathrm{f}$ & $665 \mathrm{C}$ & 17 & \\
\hline 4 & $87 \mathrm{INE}$ & 60 & $1,120 \mathrm{C}$ & 7 & 1,2100 & 18 & $64 ! 40$ & 5 & $32 \mathrm{NE}$ & $c_{1}$ & $563 T$ & $\mathrm{f}$ & $1,060 \mathrm{C}$ & 24 & 1,3000 \\
\hline 4 & $88 \mathrm{NE}$ & 60 & $994 \mathrm{C}$ & 3 & $994 \mathrm{C}$ & 18 & $488 \mathrm{~T}$ & 5 & $5 \mathrm{LWN}$ & $a$ & 1,1900 & $f$ & $903 T$ & 24 & $553 T$ \\
\hline 4 & $89 \mathrm{NE}$ & 75 & 8300 & 3 & $597 \mathrm{C}$ & 18 & 9137 & 5 & $52 \mathrm{NE}$ & 0 & $\mathrm{NR}$ & $f$ & $\mathrm{NR}$ & $\mathrm{NR}$ & INR \\
\hline 4 & 81ONE & 75 & $\mathrm{INR}$ & $\mathrm{NR}$ & $\mathrm{NR}$ & NR & $\mathrm{NR}$ & 5 & $53 \mathrm{NE}$ & 30 & $6,570 \mathrm{C}$ & $f$ & $9,530 \mathrm{C}$ & 18 & $10,700 \mathrm{C}$ \\
\hline 4 & 8IISE & 0 & NR & $\mathrm{NR}$ & $I \sqrt{K}$ & $\mathrm{NR}$ & $\mathrm{NR}$ & 5 & $54 \mathrm{NE}$ & 30 & $2,300 T$ & $f$ & $4,230 \mathrm{~T}$ & 18 & $19,300 \mathrm{~T}$ \\
\hline 4 & $8 I 2 S E$ & 0 & e & e & $887 \mathrm{C}$ & 14 & $400 T$ & 5 & $55 \mathrm{NE}$ & 60 & $1,240 \mathrm{C}$ & $f$ & $1,720 \mathrm{C}$ & 18 & $698 \mathrm{c}$ \\
\hline 4 & $9 \operatorname{InE}$ & 0 & $541 \mathrm{C}$ & 1 & $713 c$ & 18 & $418 \mathrm{C}$ & 5 & $56 \mathrm{NE}$ & 60 & 1,6000 & $f$ & $1,390 \mathrm{C}$ & 18 & $760 \mathrm{C}$ \\
\hline 4 & $92 \mathrm{NE}$ & 0 & 2,6500 & $I$ & -- & -- & - & 5 & $5 \perp \mathrm{NB}$ & 8 & $663 \mathrm{~T}$ & 3 & $920 \mathrm{~T}$ & 17 & $322 \mathrm{~T}$ \\
\hline 4 & IOLNE & 0 & $585 \mathrm{C}$ & 5 & $857 \mathrm{C}$ & 19 & $741 C$ & 5 & $52 \mathrm{NB}$ & 24 & $1,300 \mathrm{~T}$ & 8 & $1,440 \mathrm{~T}$ & 17 & $356 \mathrm{~T}$ \\
\hline 4 & $102 \mathrm{NE}$ & 0 & 1,4300 & 2 & INR & $\mathrm{INR}$ & $\mathrm{IR}$ & 5 & $53 \mathrm{NB}$ & 45 & $1,370 T$ & 8 & $1,610 \mathrm{~T}$ & 18 & $438 \mathrm{~T}$ \\
\hline 4 & $103 \mathrm{NE}$ & 30 & $1,750 \mathrm{C}$ & 7 & 2,2900 & 19 & $2,120 \mathrm{C}$ & 5 & $54 \mathrm{NB}$ & 67 & $1,220 \mathrm{~T}$ & 9 & $1,320 \mathrm{~T}$ & 19 & $544 \mathrm{~T}$ \\
\hline 4 & $104 \mathrm{NE}$ & 30 & $2,300 \mathrm{C}$ & 12 & $2,790 \mathrm{C}$ & 20 & 4,5700 & 5 & $55 \mathrm{NBB}$ & 83 & $1,380 \mathrm{~T}$ & 8 & $1,560 \mathrm{~T}$ & 17 & $26 \pi T$ \\
\hline 4 & $105 \mathrm{NE}$ & 45 & $1,240 \mathrm{C}$ & 6 & $1,790 \mathrm{C}$ & 19 & 2,3300 & 5 & $565 B$ & 45 & INR & $\mathrm{NR}$ & $\mathbb{N R}$ & $\mathrm{NR}$ & $\mathrm{NR}$ \\
\hline 4 & $106 \mathrm{NE}$ & 45 & $797 \mathrm{C}$ & 8 & 2,2900 & 30 & 3,7900 & & & & & & & & \\
\hline 4 & $107 \mathrm{NE}$ & 60 & $938 \mathrm{C}$ & 7 & 1,2400 & 19 & $1,280 \mathrm{C}$ & & & & & & & & \\
\hline 4 & $108 \mathrm{NE}$ & 60 & $I R$ & $\mathbb{N R}$ & $\mathrm{IR}$ & $\mathrm{NR}$ & $\mathrm{NR}$ & & & & & & & & \\
\hline 4 & I09RE & 75 & INR & $\mathrm{IRR}$ & $\mathrm{NR}$ & INR & $\mathrm{IR}$ & & & & & & & & \\
\hline 4 & 1010NE & 75 & $243 \mathrm{C}$ & 2 & $320 \mathrm{C}$ & 19 & $744 \mathrm{~T}$ & & & & & & & & \\
\hline 4 & 1017SE & 0 & $I, 250 \mathrm{C}$ & 7 & $1,120 \mathrm{C}$ & 19 & $785 \mathrm{C}$ & & & & & & & & \\
\hline 4 & 1012SE & 0 & $\mathrm{IR}$ & $\mathrm{NR}$ & $\mathrm{INR}$ & $\mathrm{NR}$ & $\mathrm{I} R$ & & & & & & & & \\
\hline 4 & $5 \mathrm{IIBB}$ & 8 & $559 \mathrm{~T}$ & 8 & $476 \mathrm{~T}$ & 17 & $103 \mathrm{~T}$ & & & & & & & & \\
\hline
\end{tabular}

c Inches above the truss-bulkhead beam connecting bolt center.

( 4 of 4 sheets)

e No reflection apparent.

Because of difficulties experienced and explained in the text it was impossible to determine these data for Shot No. 5. 


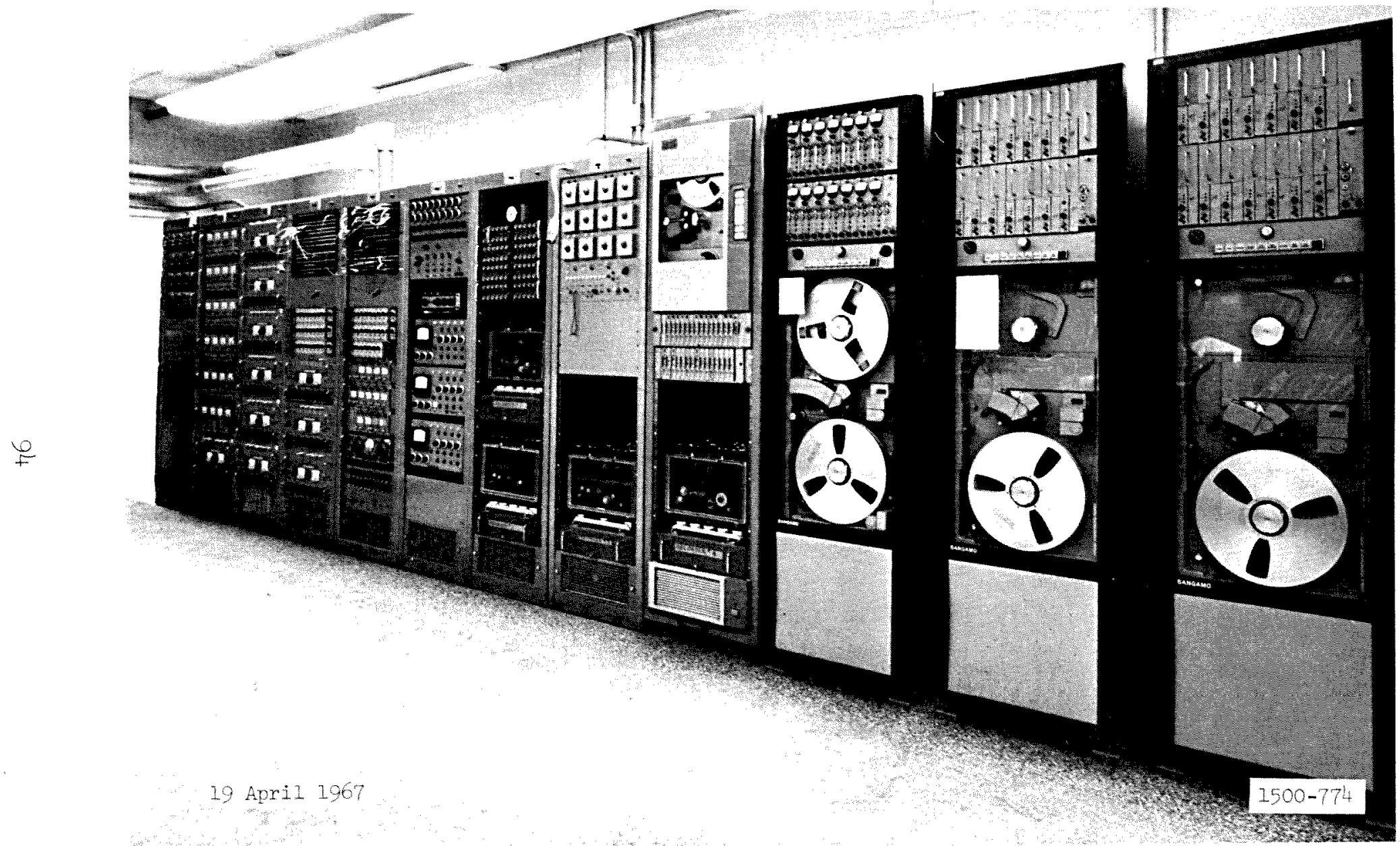

Figure A.I General view of the recording and conditioning equipment. 


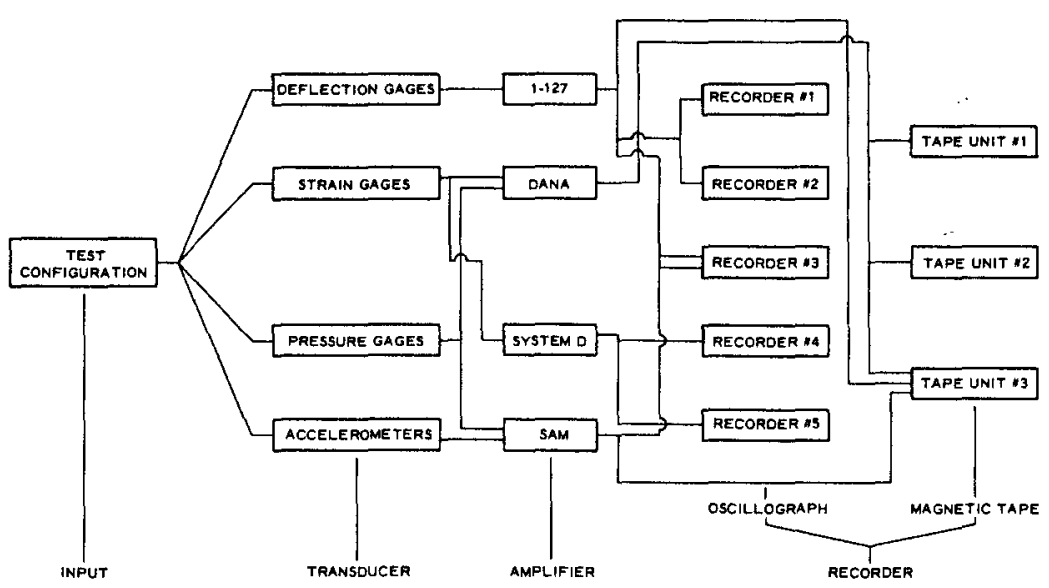

a. SHOTS 1 AND 2

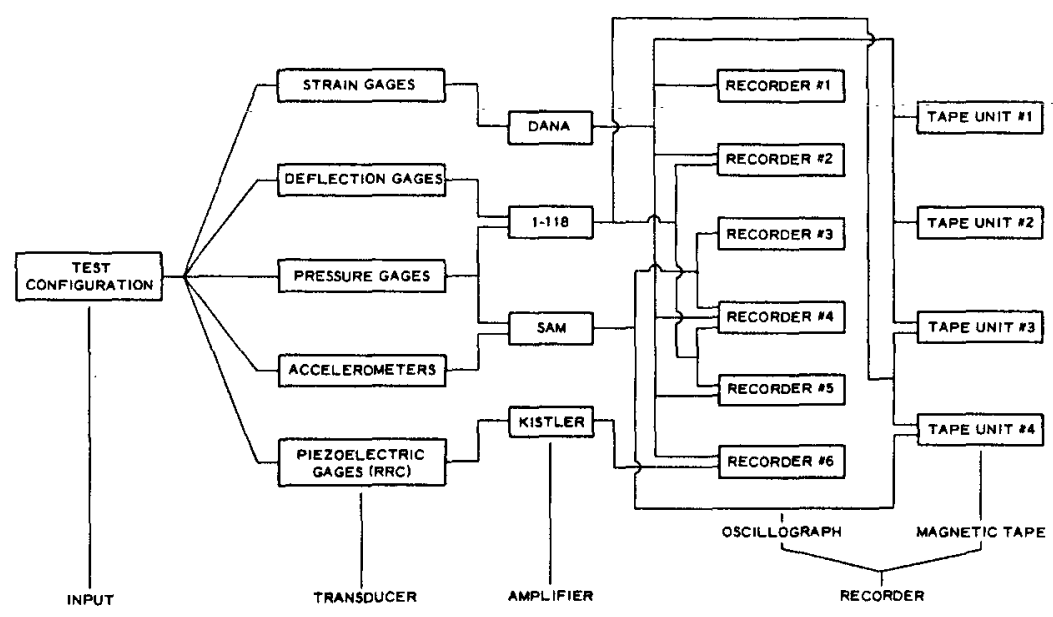

b. SHOTS 3 AND 4

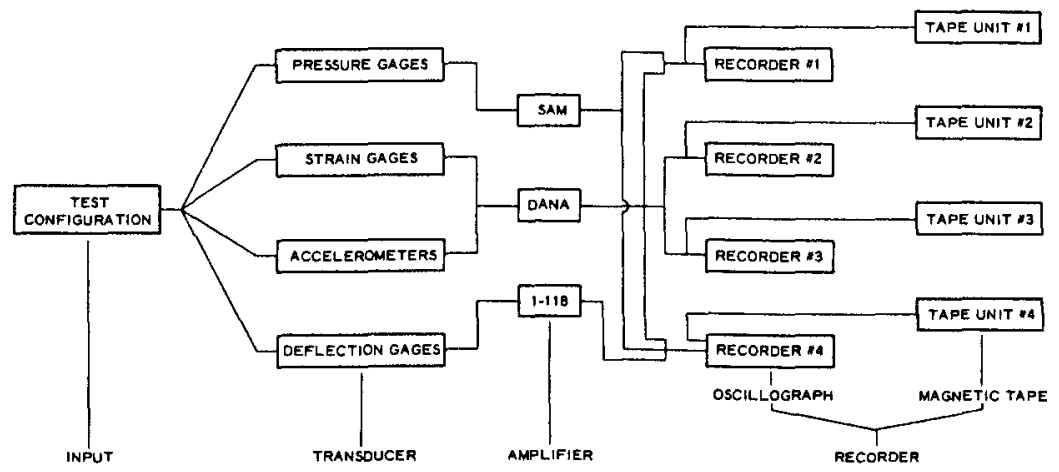

c. SHOT 5

Figure A.2 Instrumentation diagrams for shots 1 to 5 . 

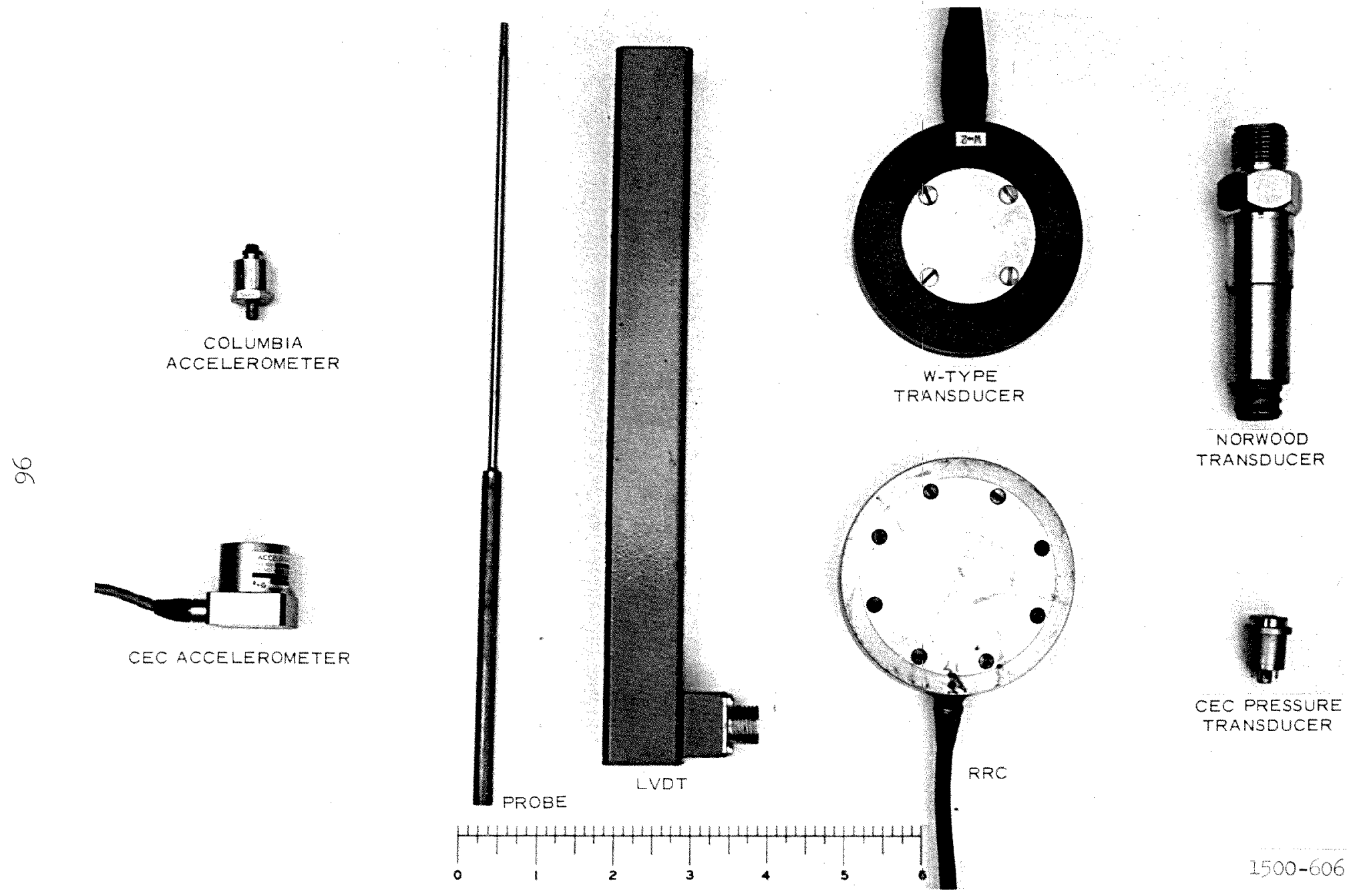

Figure A.3 Transducers used during the test series. 


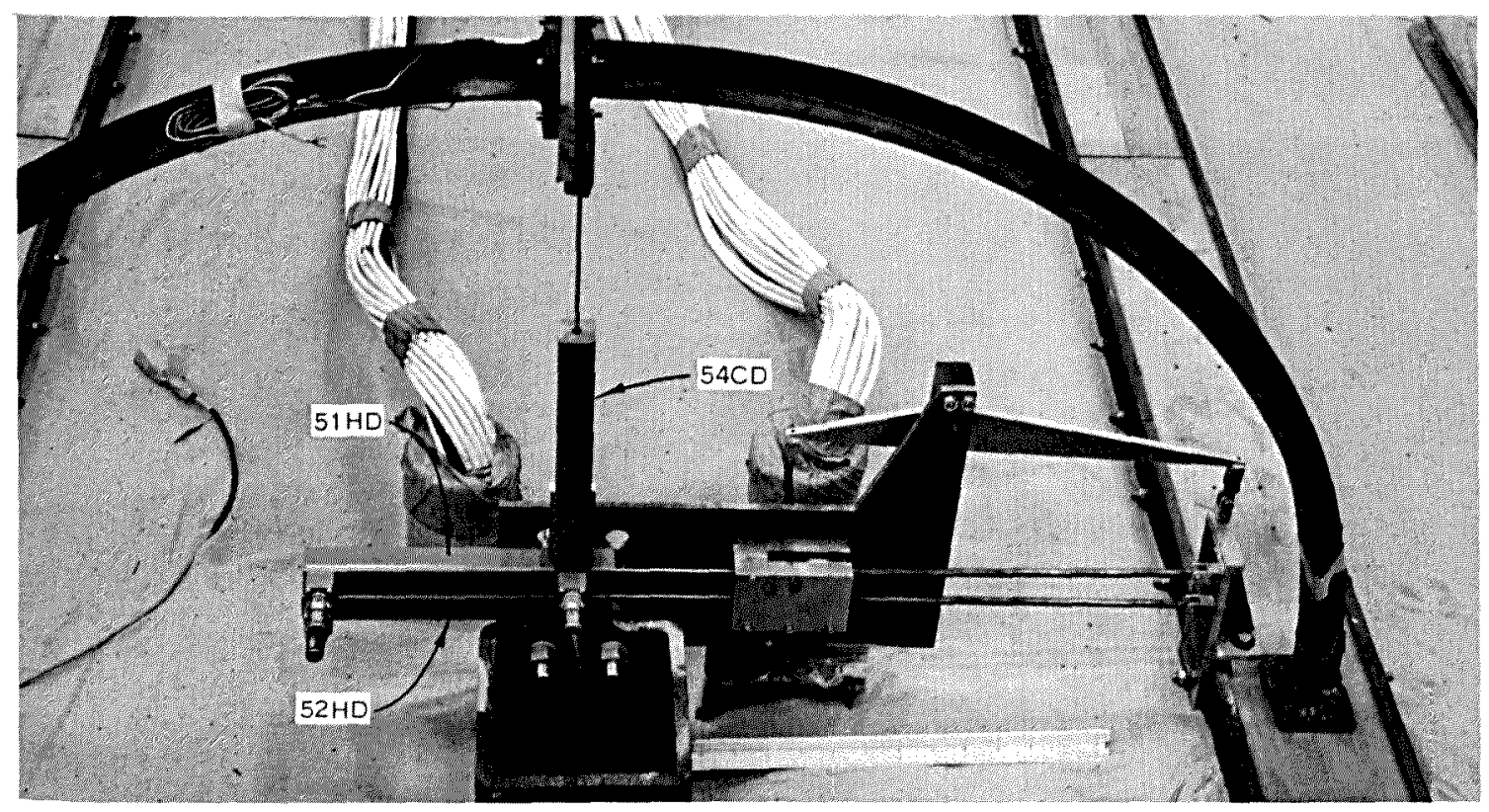

a. East side.

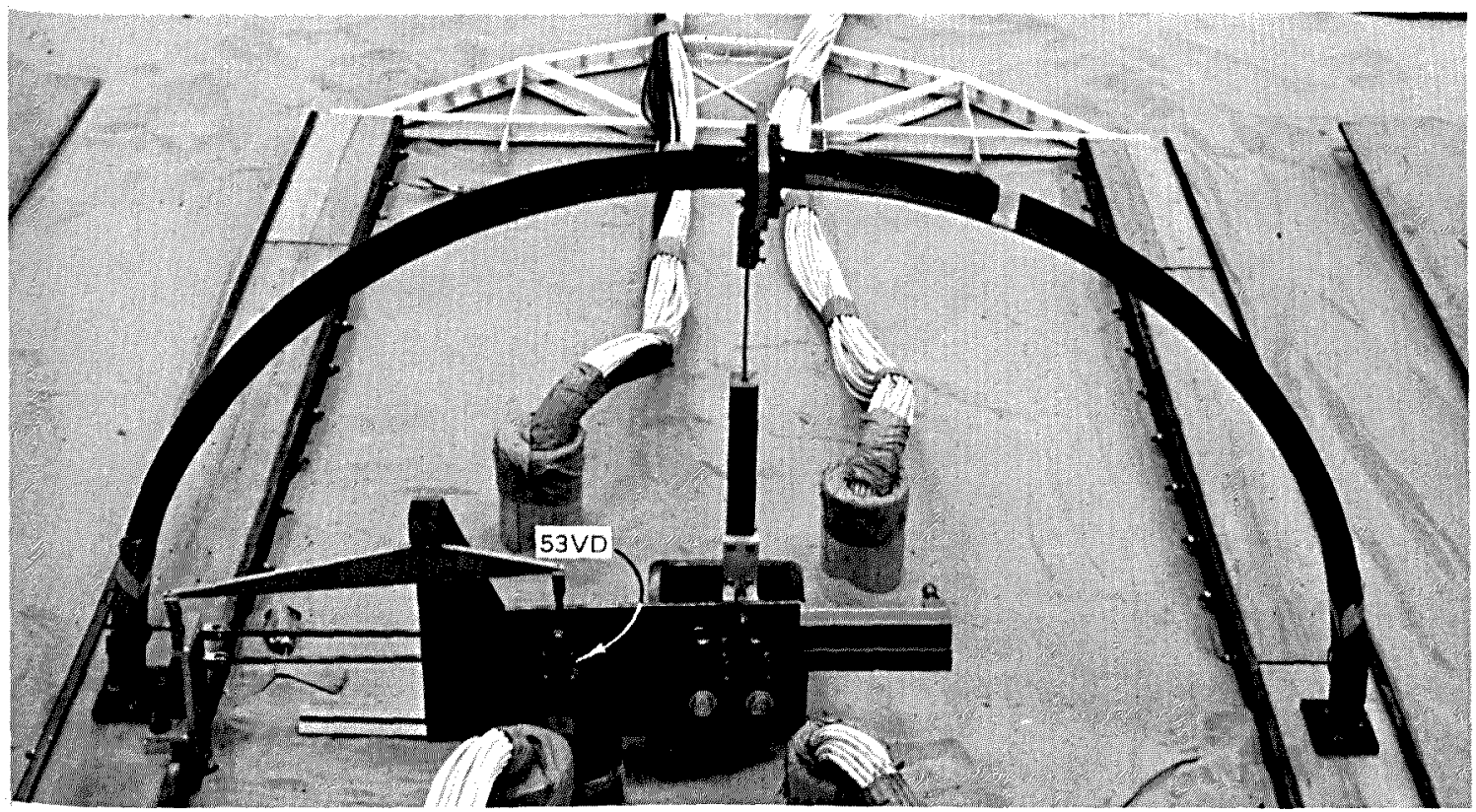

b. West side.

Figure A.4 Footing and crown deflection rig, Preshot 1. 


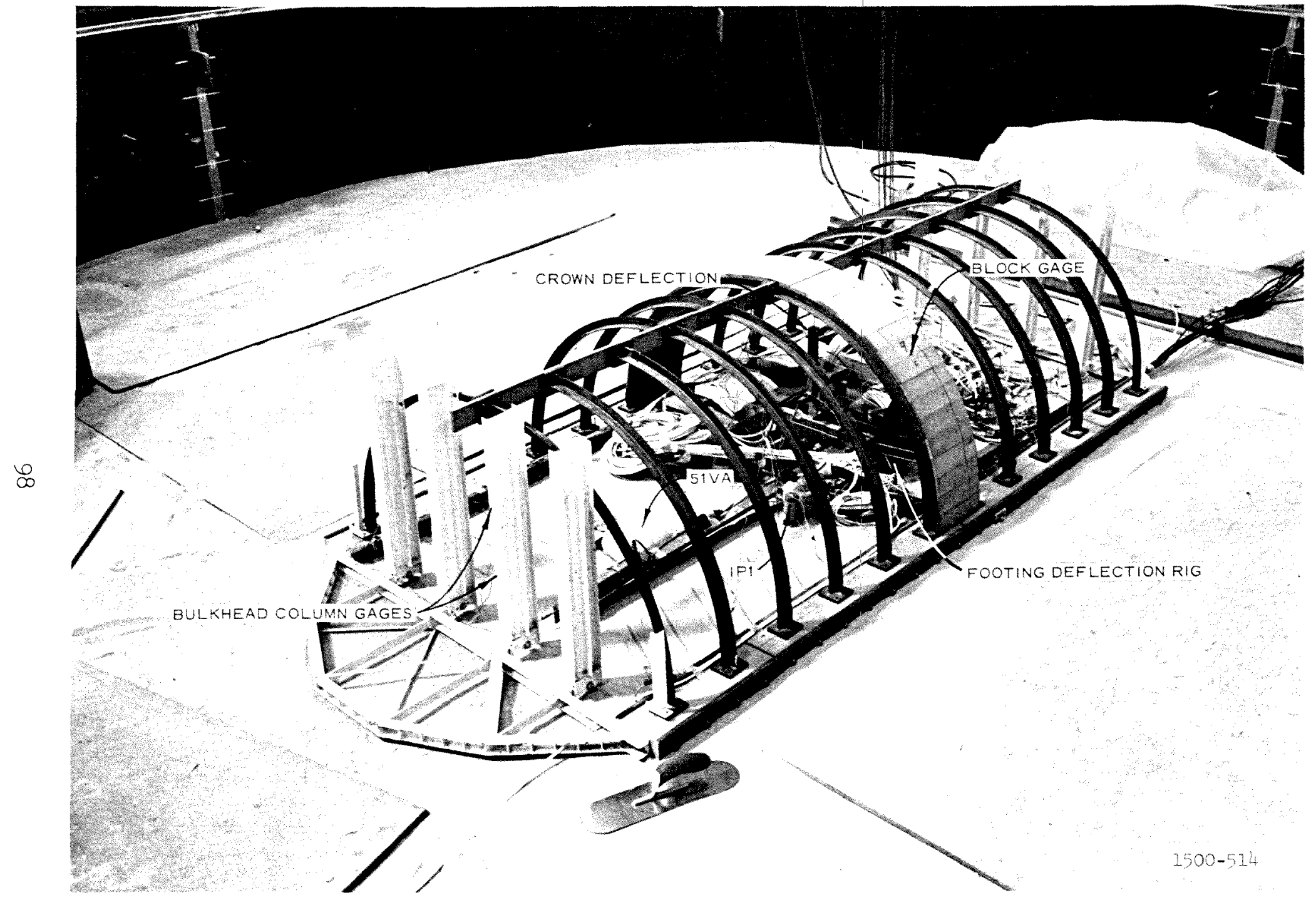

Figure A.5 Fully instrumented structure prior to placing timber lagging, Preshot 3. 


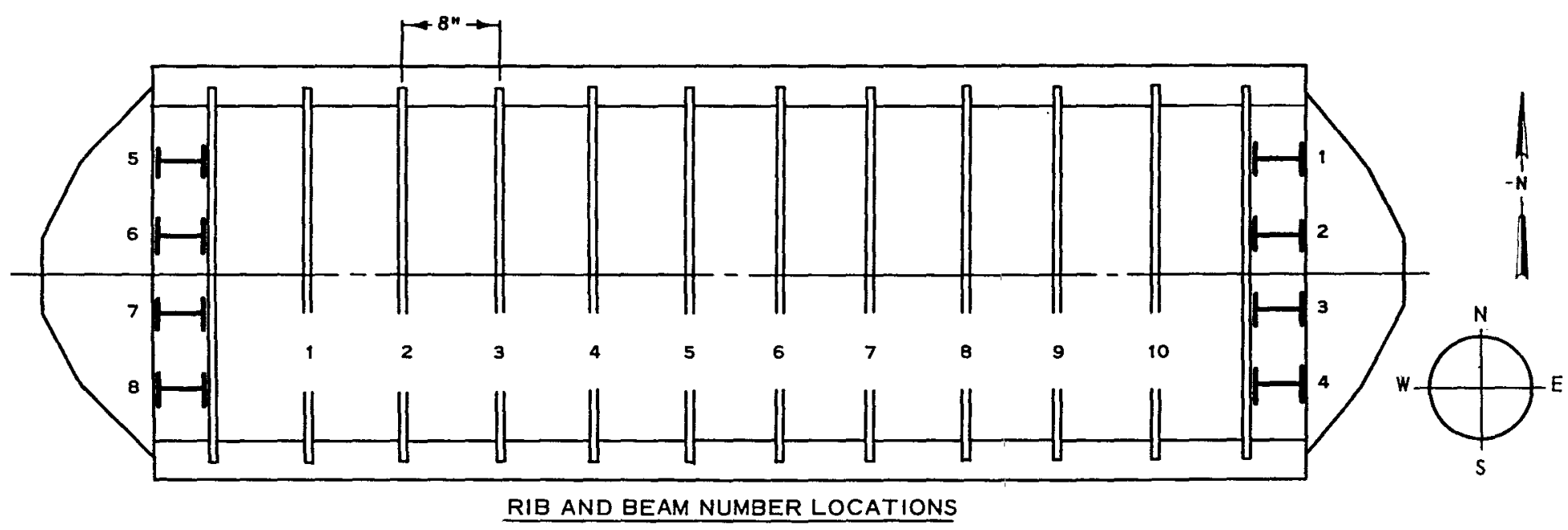

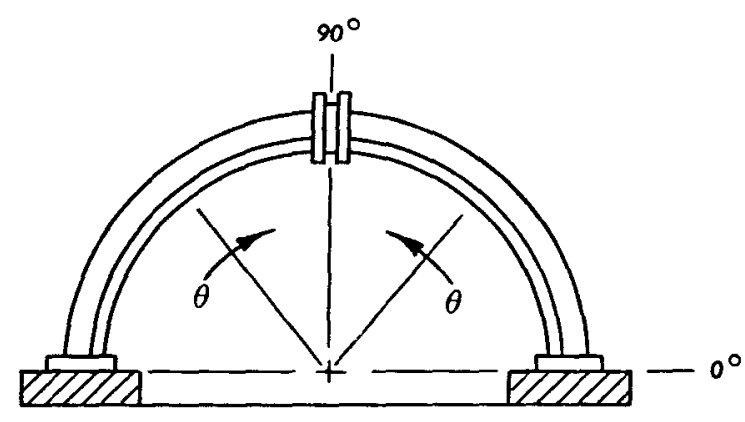

RIB ANGLE CONVENTION

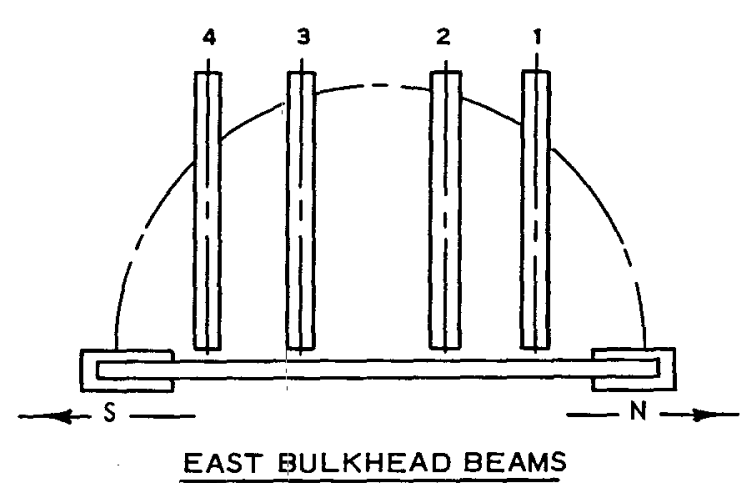

Figure A.6 Numbering convention. 

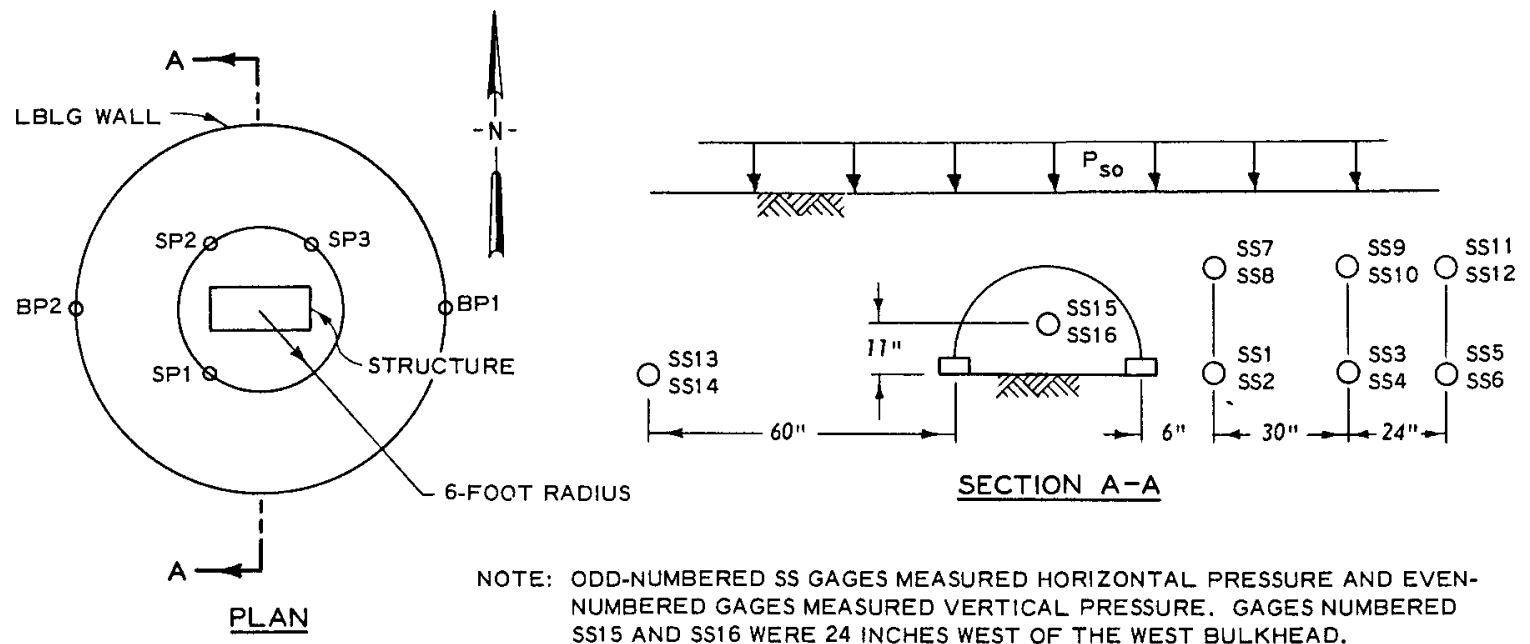

SECTION A-A

NOTE: ODD-NUMBERED SS GAGES MEASURED HORIZONTAL PRESSURE AND EVENNUMBERED GAGES MEASURED VERTICAL PRESSURE. GAGES NUMBERED SS15 AND SS16 WERE 24 INCHES WEST OF THE WEST BULKHEAD.

\section{PRESSURE GAGE LOCATHONS}
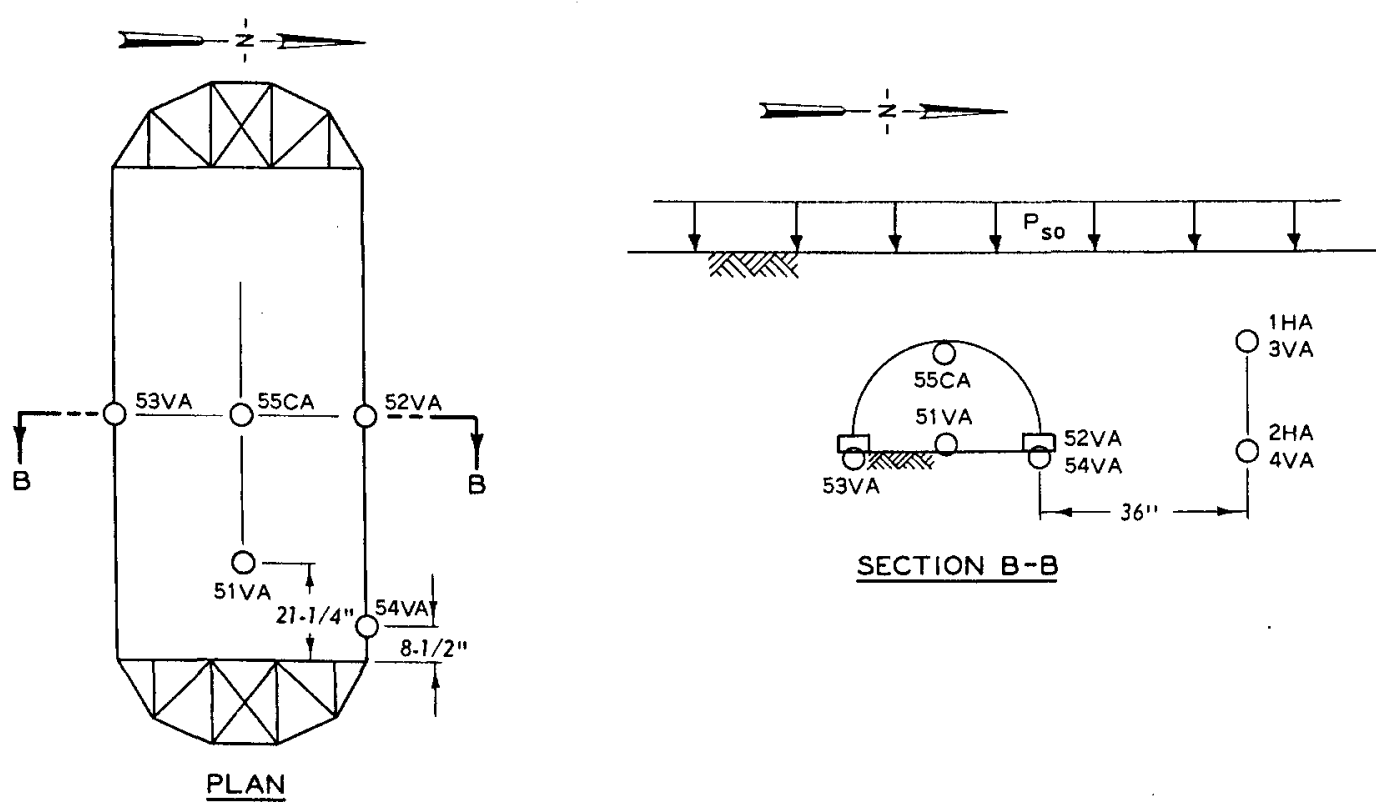

SECTION B-B

\section{ACCELEROMETER LOCATIONS}

Figure A.7 Free-field and motion gage locations. 
APPENDIX B

RAW DATA 

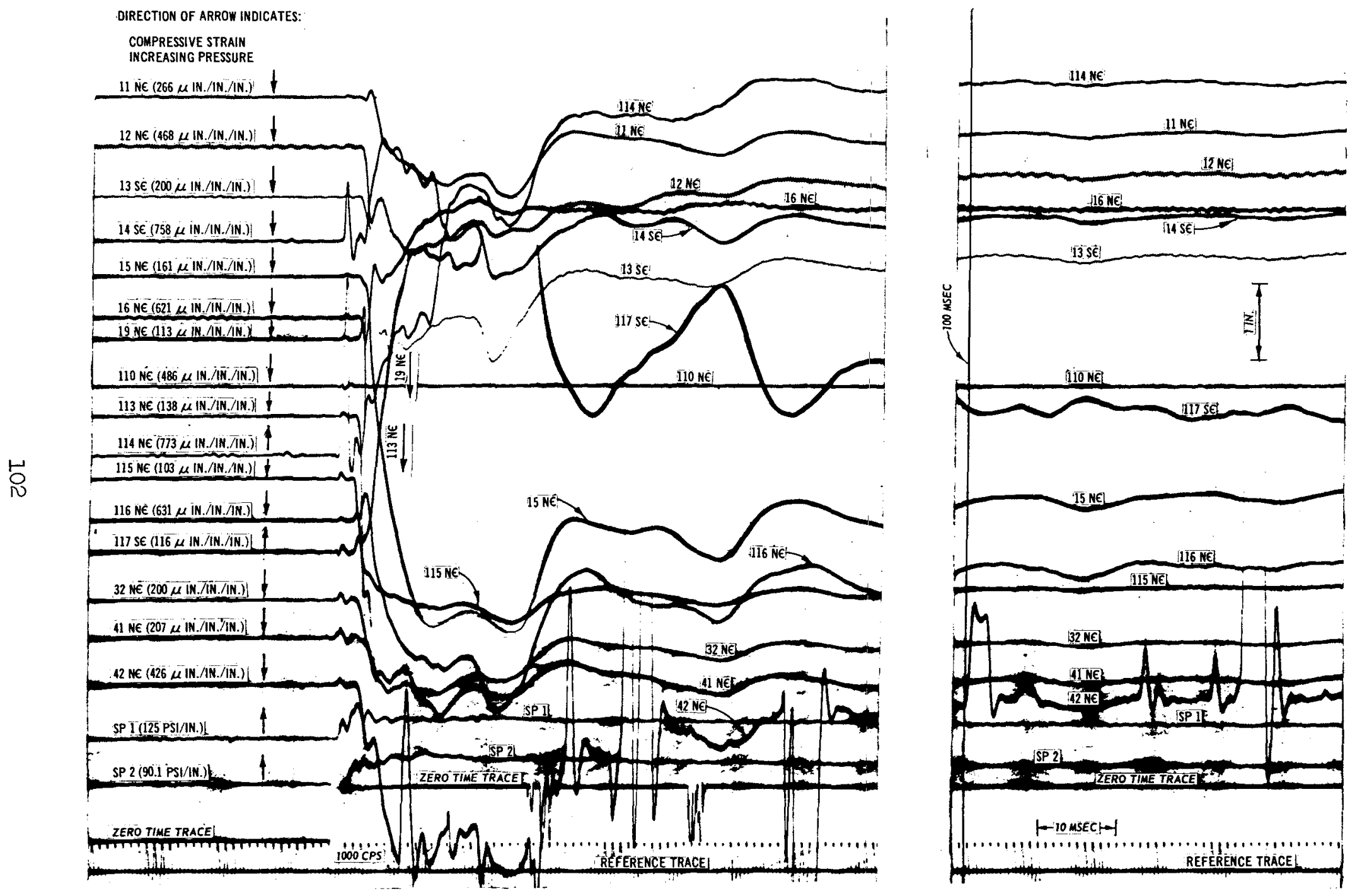

Figure B.I Shot 1, oscillograph record from Recorder 1. 

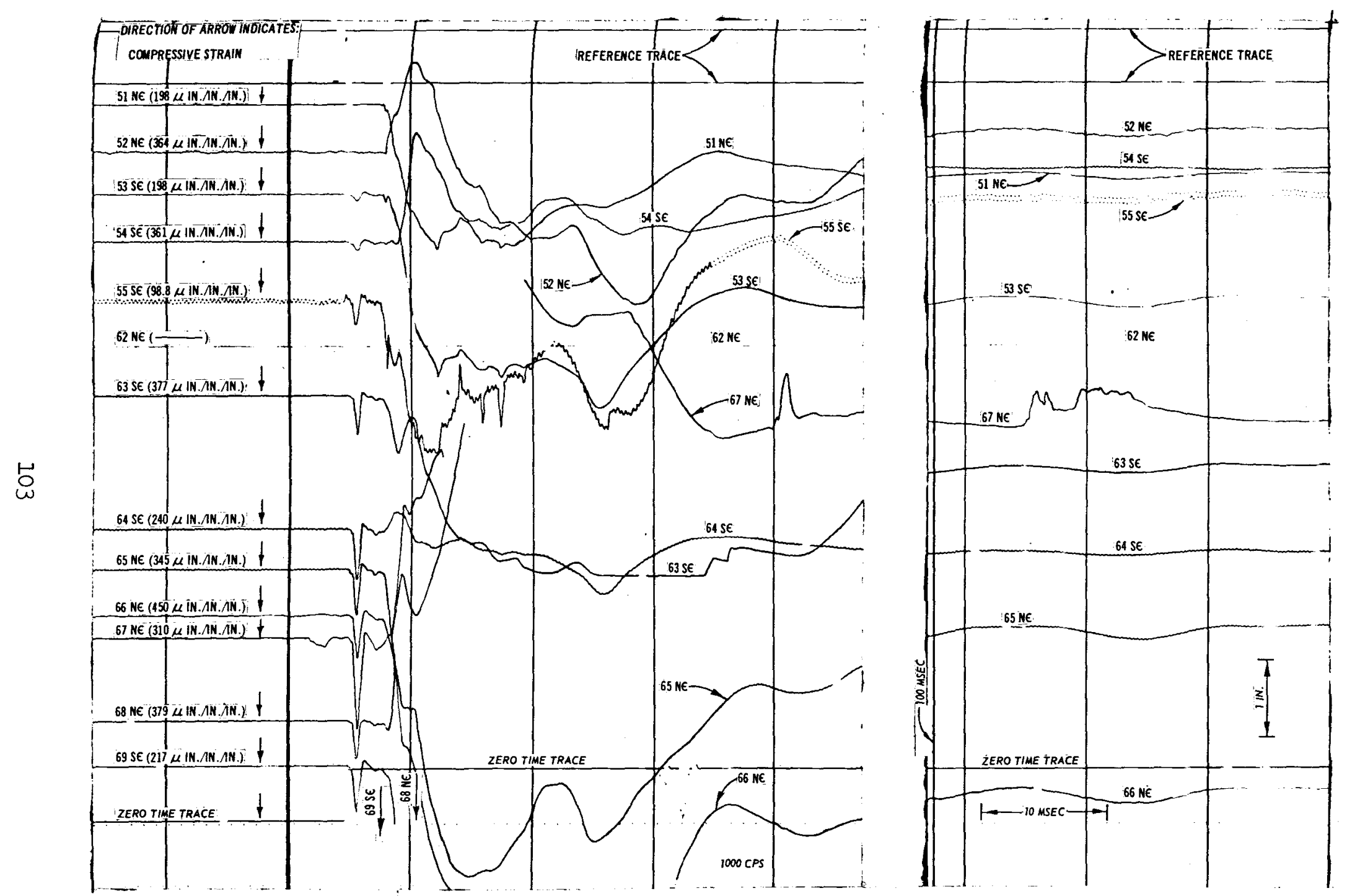

Figure B.2 Shot 1, oscillograph record from Recorder 2. 

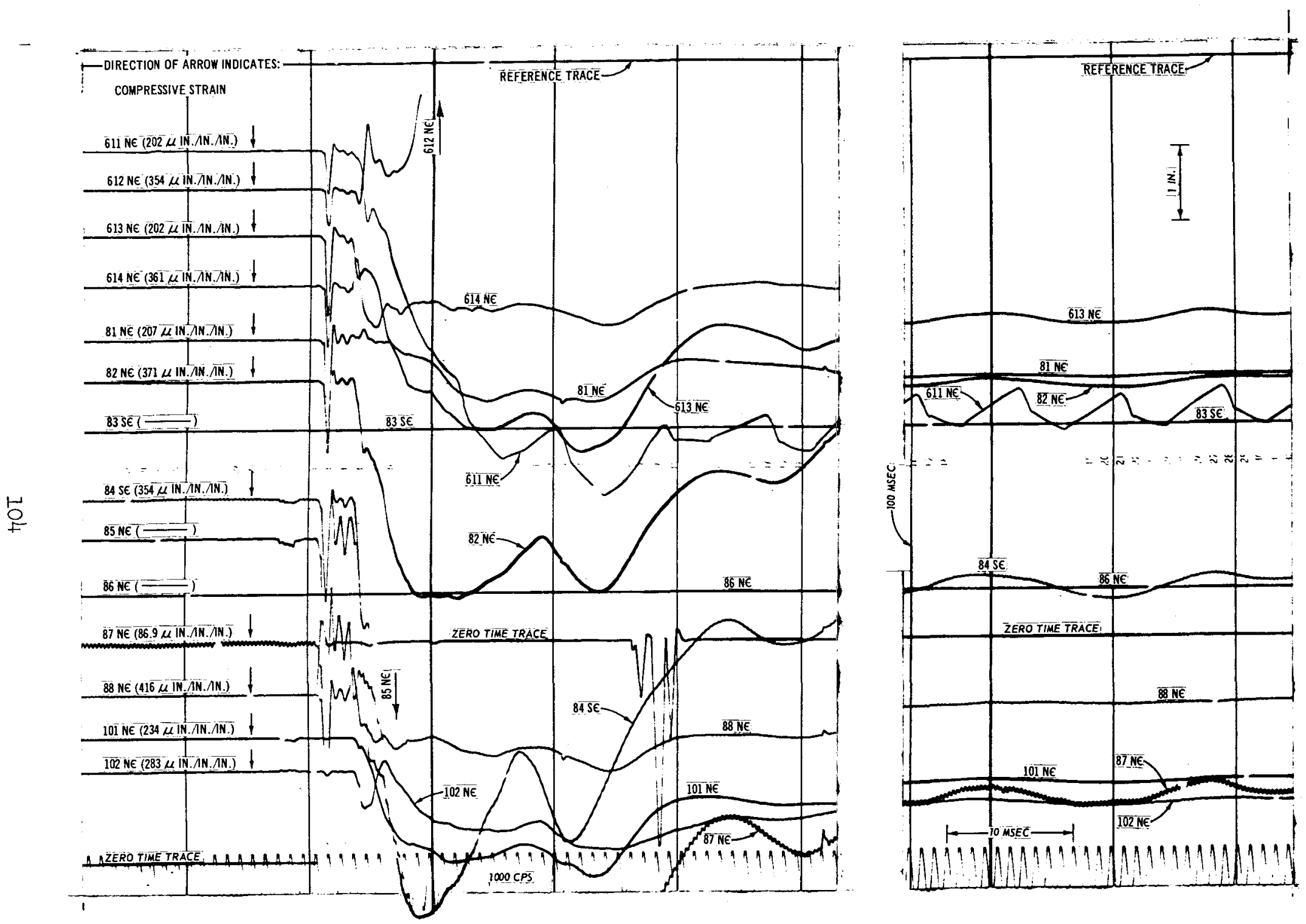

Figure B.3 Shot 1, oscillograph record from Recorder 3. 

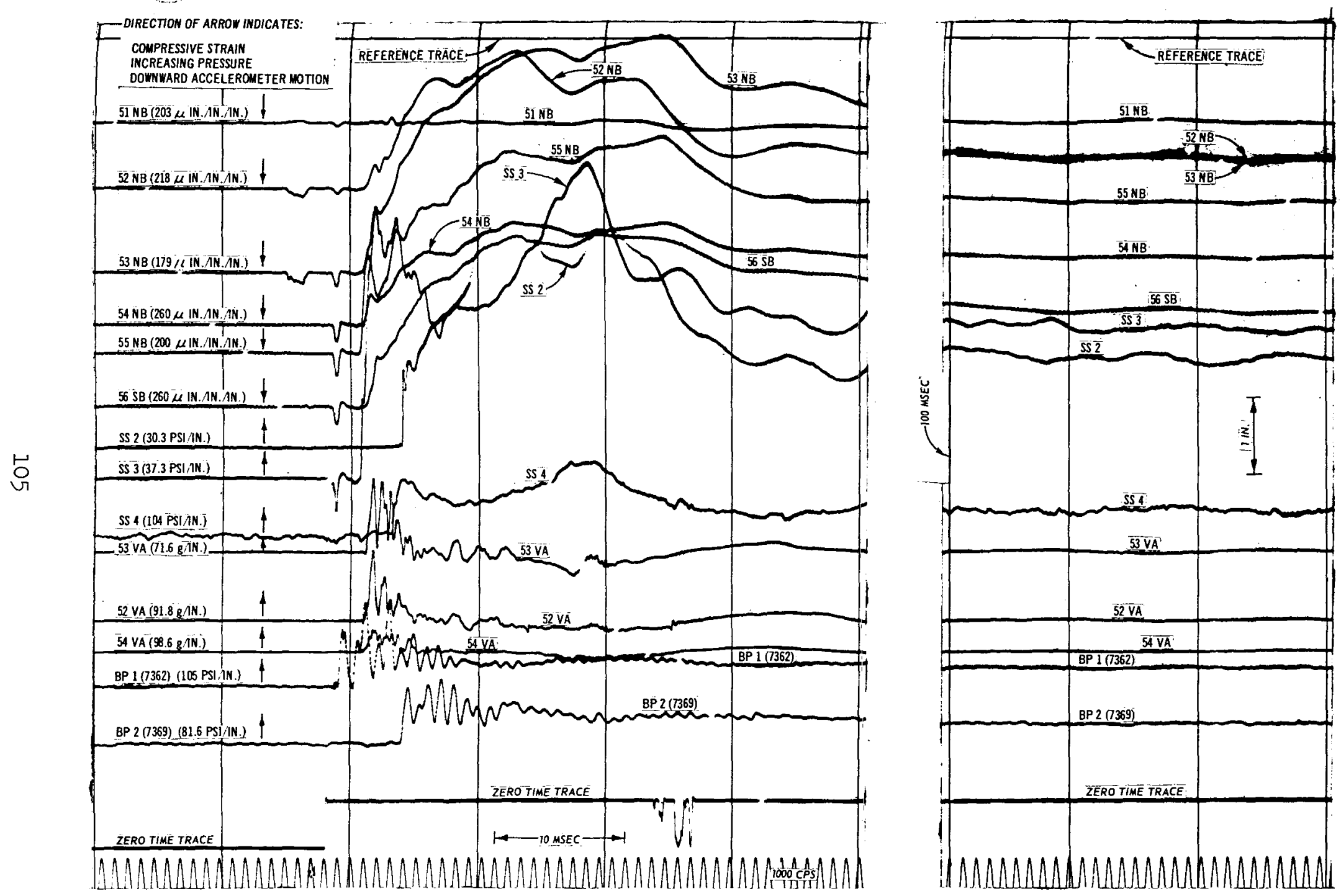

Figure B.4 Shot 1, oscillograph record from Recorder 4. 

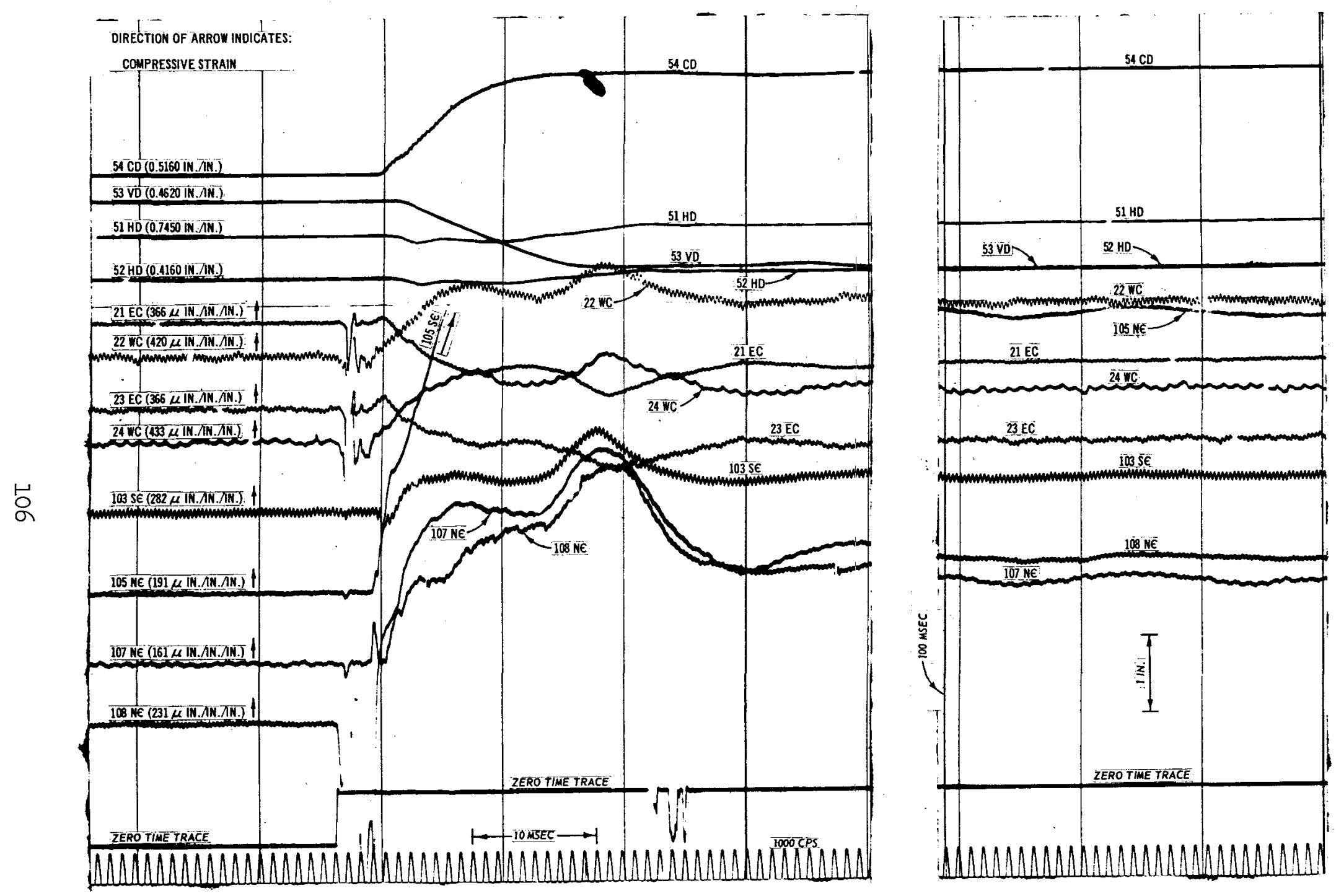

Figure B.5 Shot 1, oscillograph record from Recorder 5. 

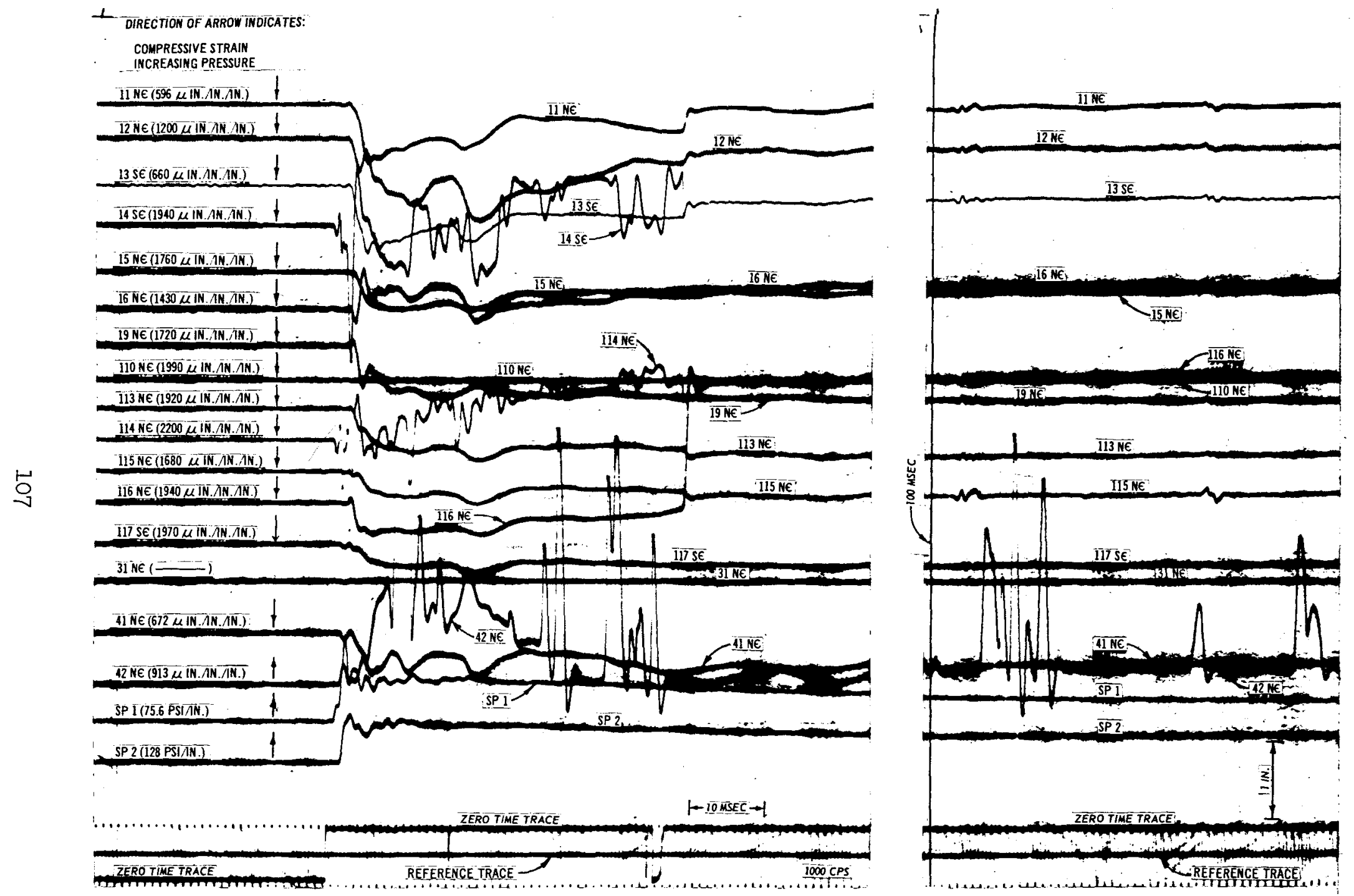

Figure B.6 Shot 2, oscillograph record from Recorder 1. 

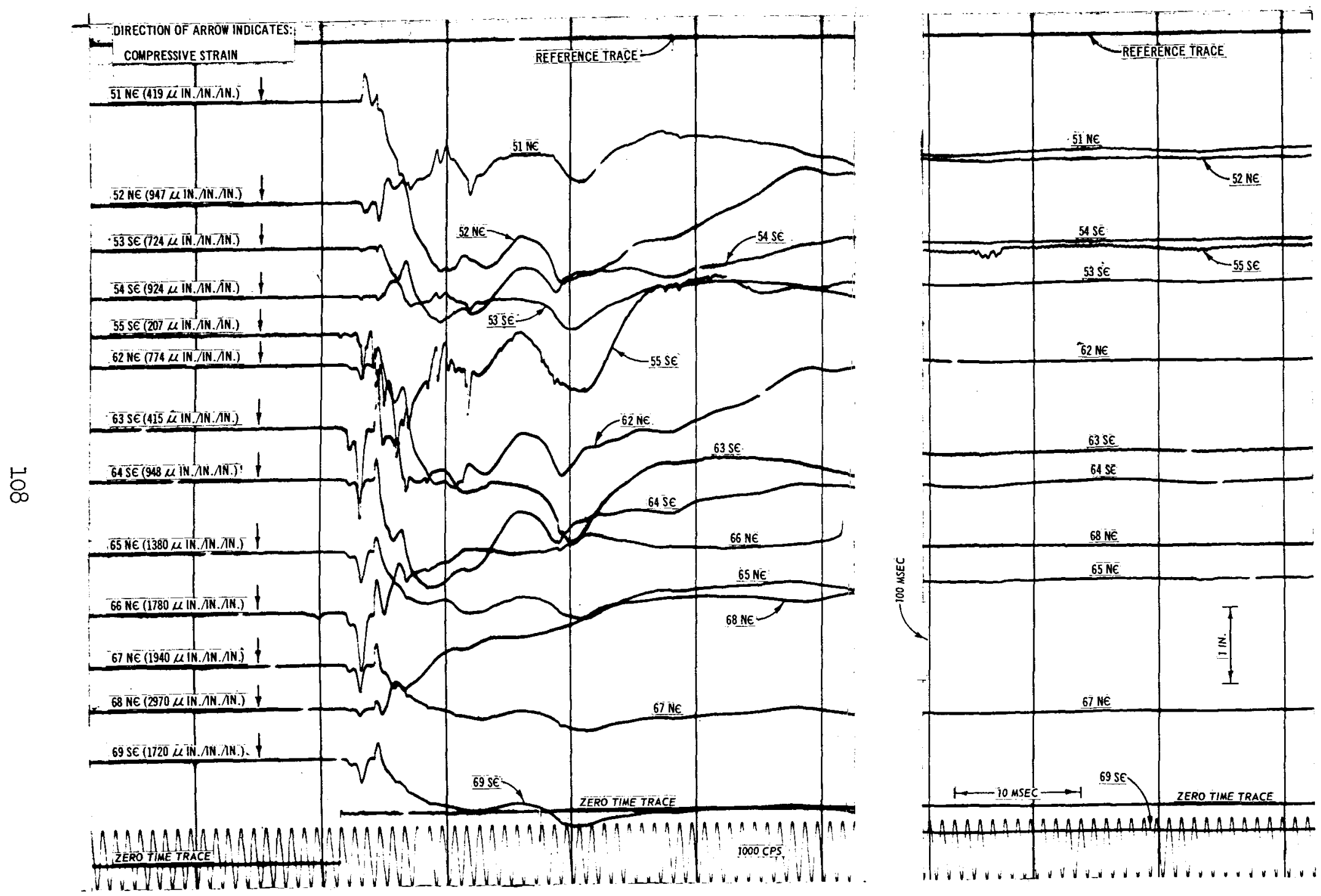

Figure B.7 Shot 2, oscillograph record from Recorder 2. 

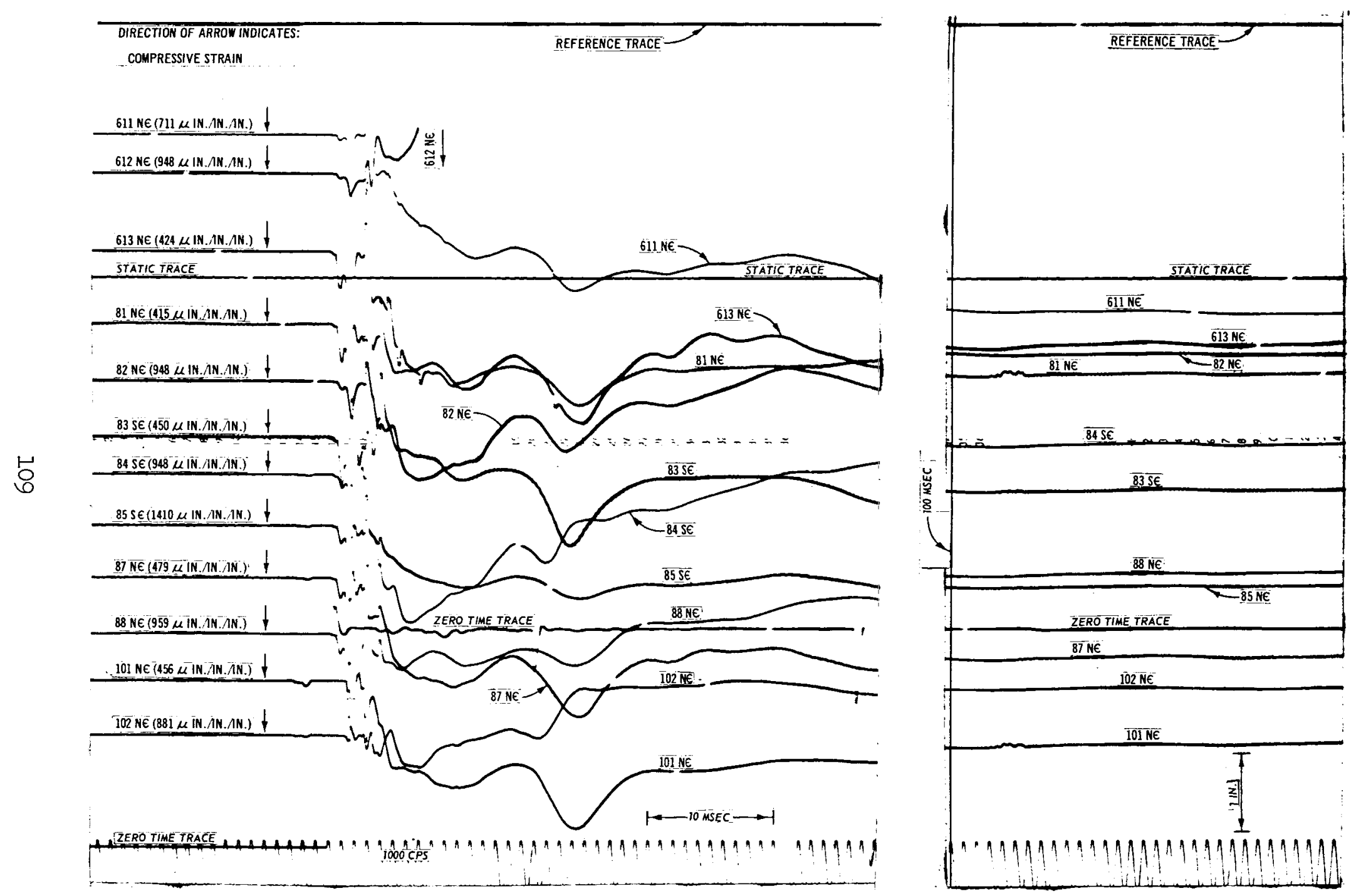

Figure B.8 Shot 2, oscillograph record from Recorder 3. 

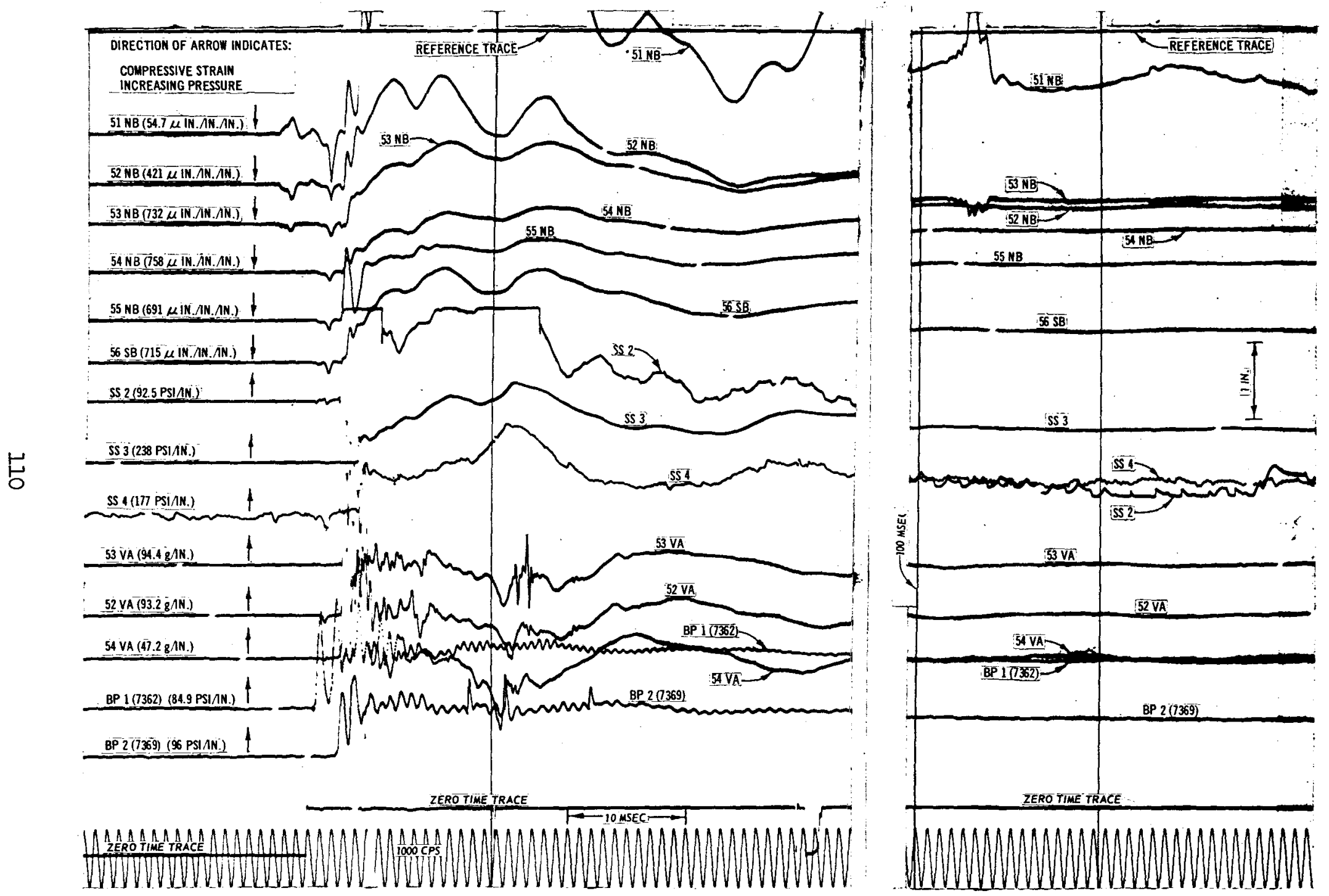

Figure B.9 Shot 2, oscillograph record from Recorder 4. 

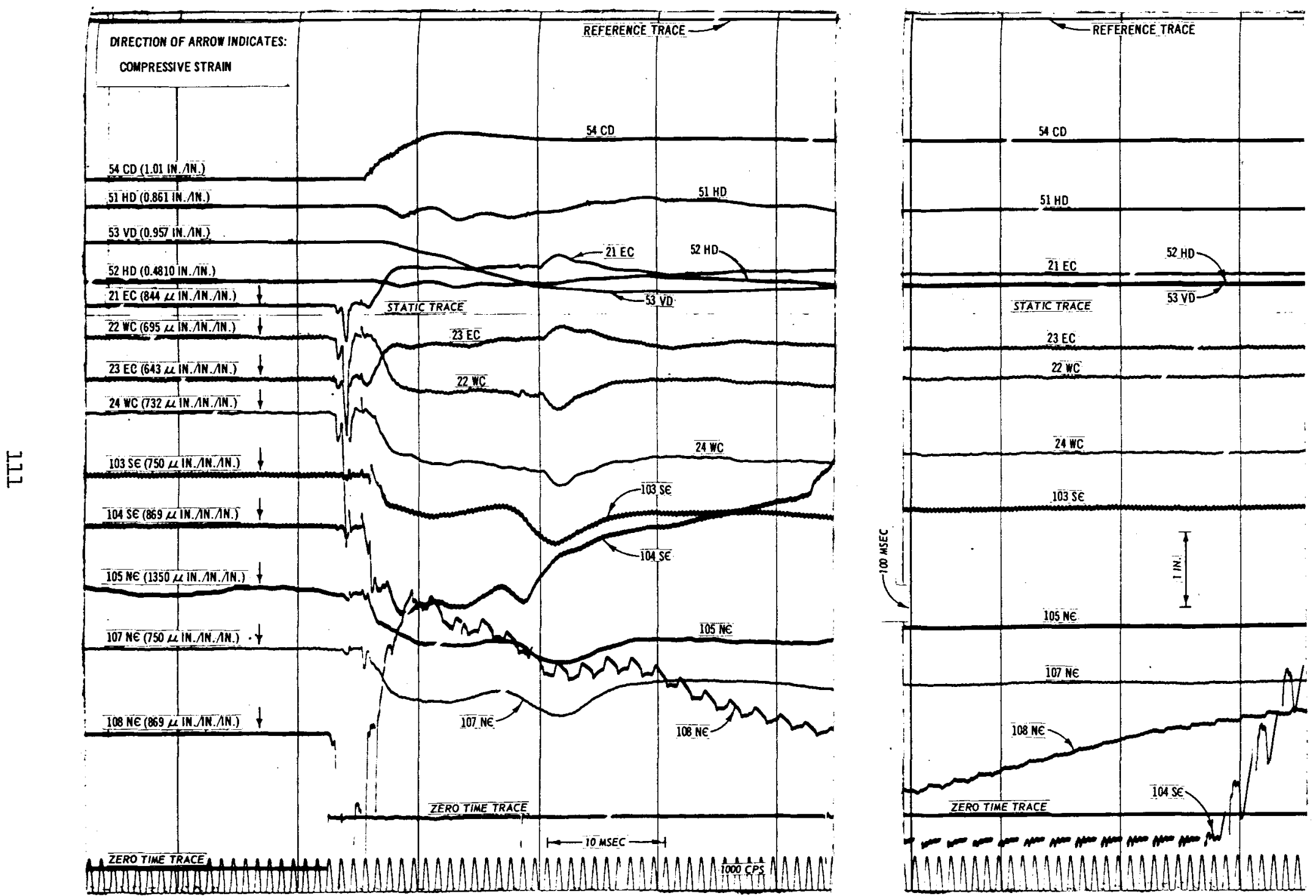

Figure B.10 Shot 2, oscillograph record from Recorder 5 . 

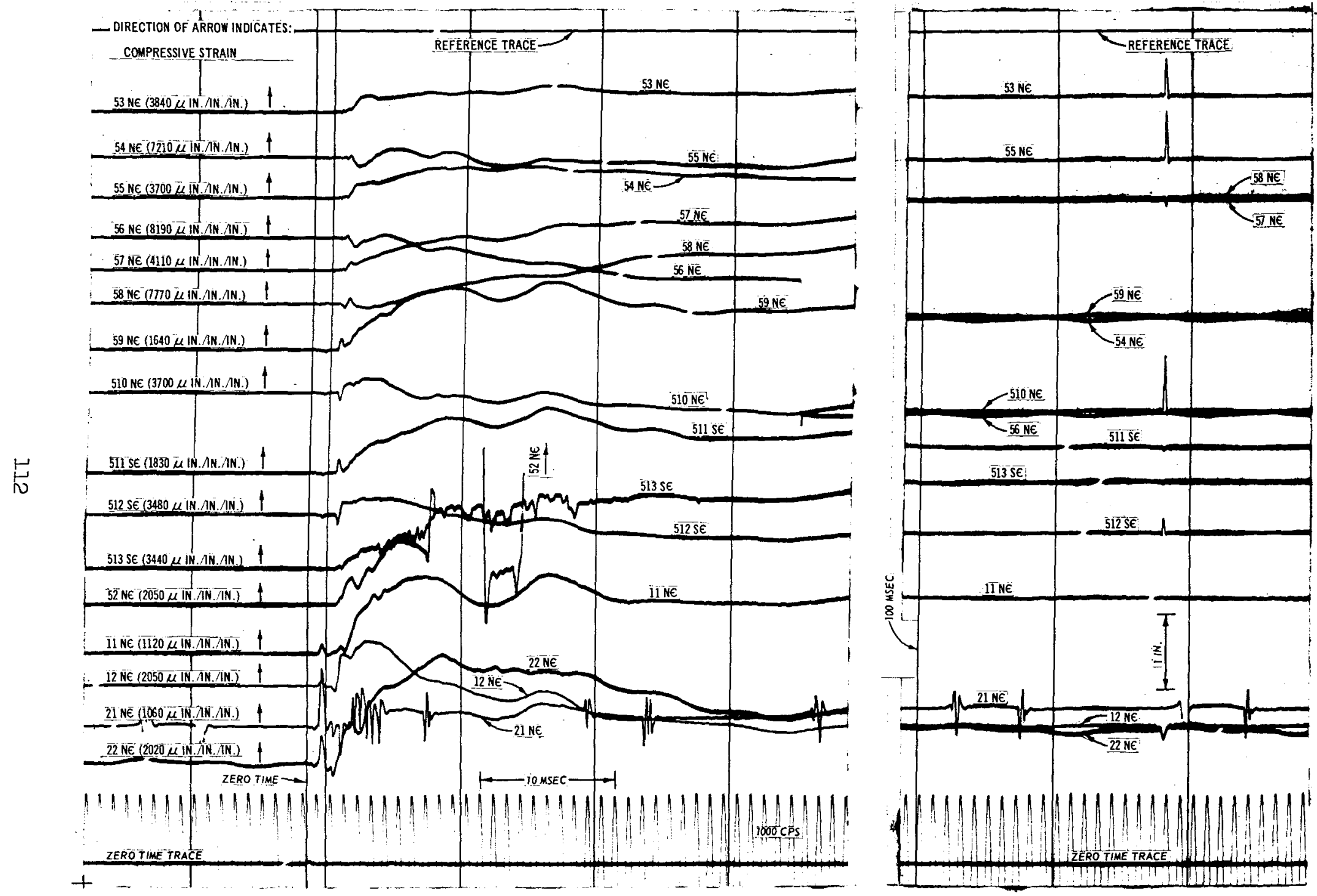

Figure B.1l Shot 3, oscillograph record from Recorder 1. 

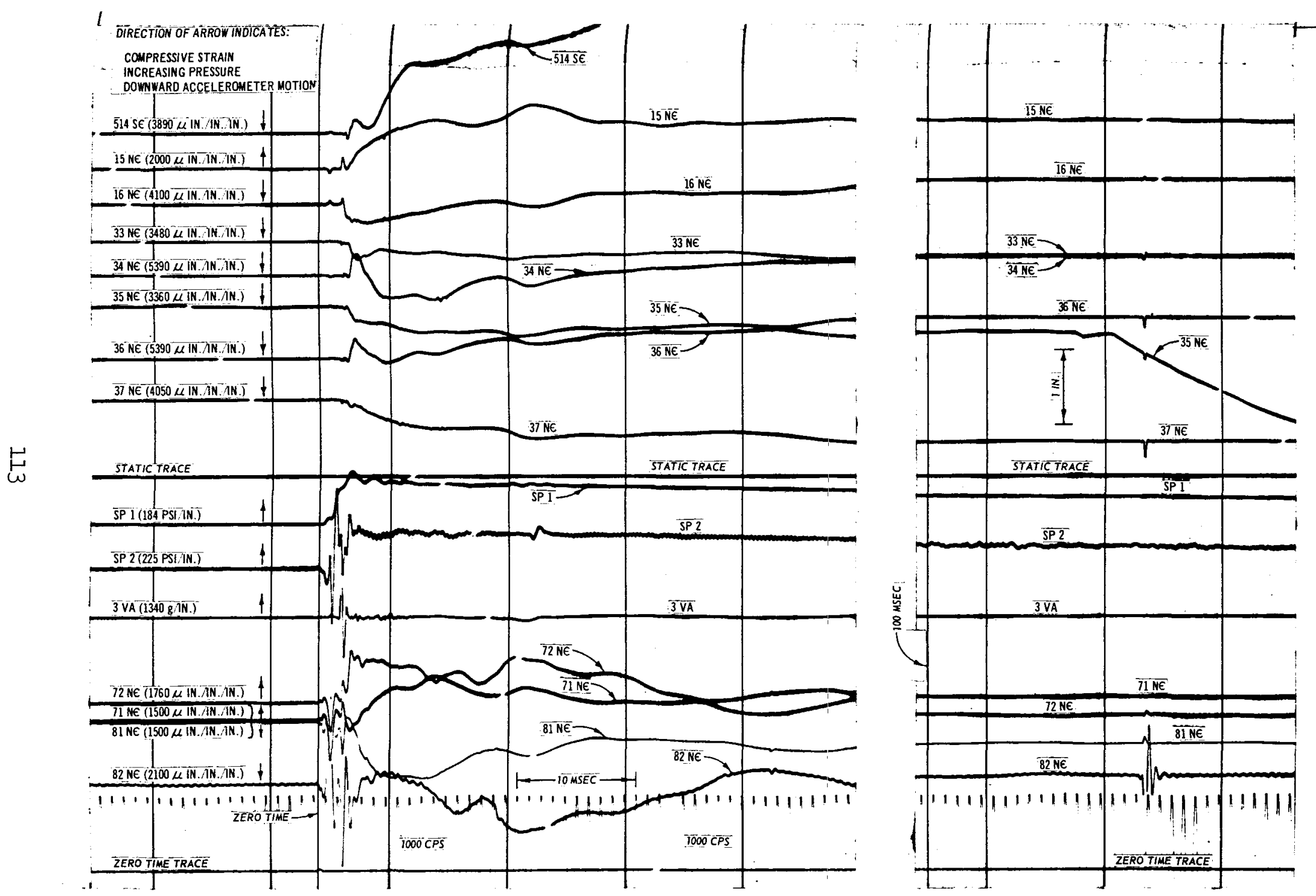

Figure B.12 Shot 3, oscillograph record from Recorder 2. 

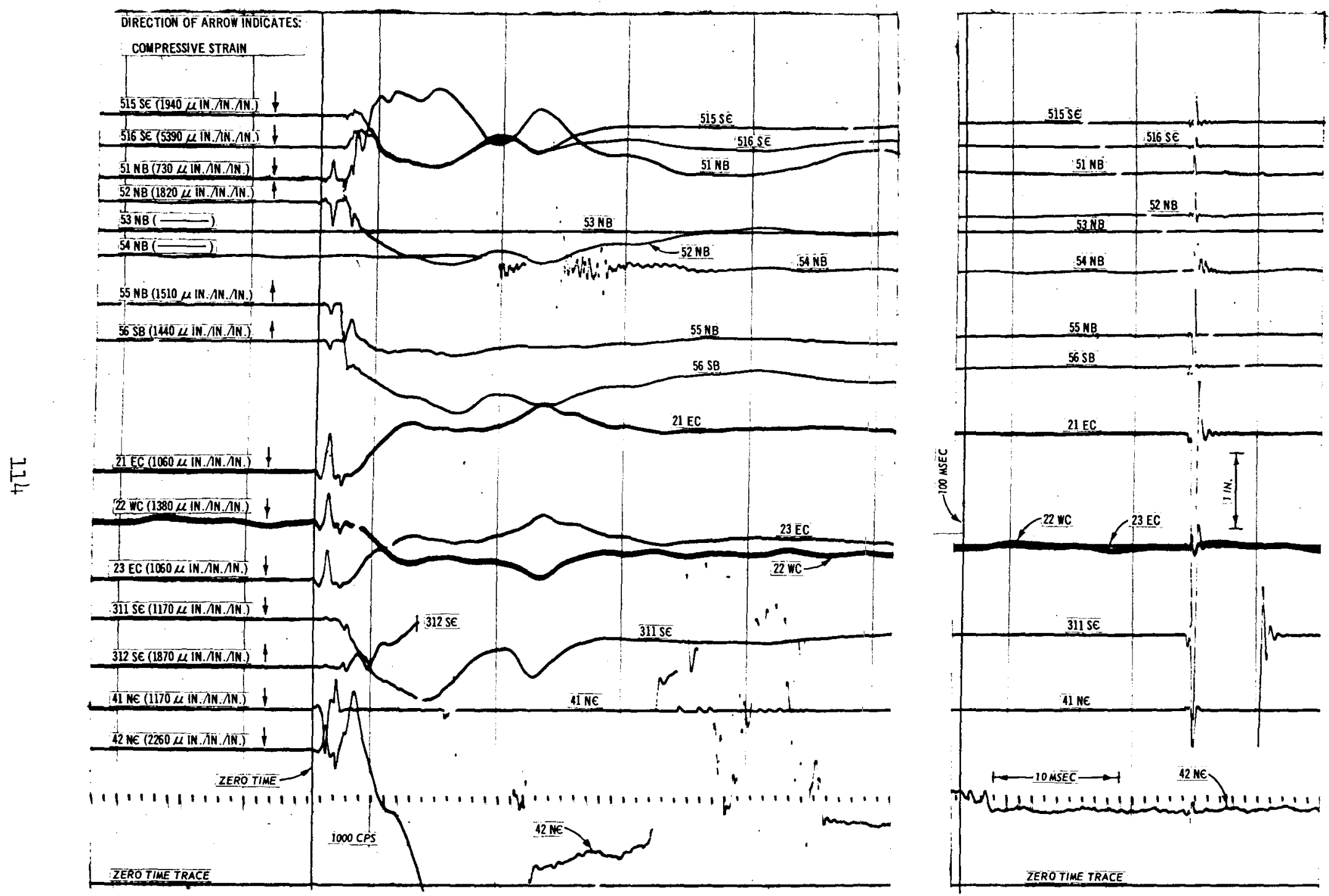

Figure B.13 Shot 3, oscillograph record from Recorder 3. 

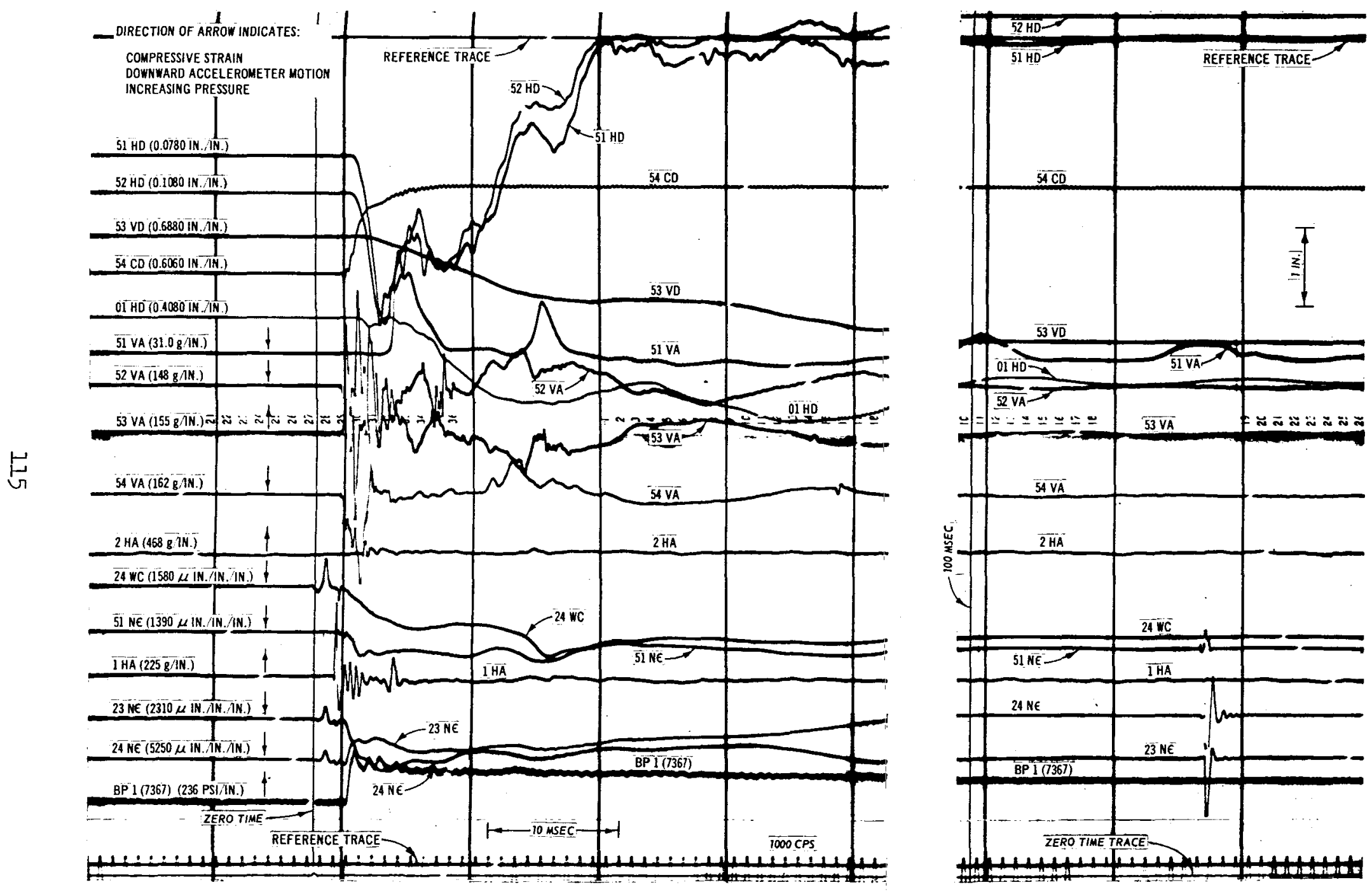

Figure B.14 Shot 3, oscillograph record from Recorder 4. 


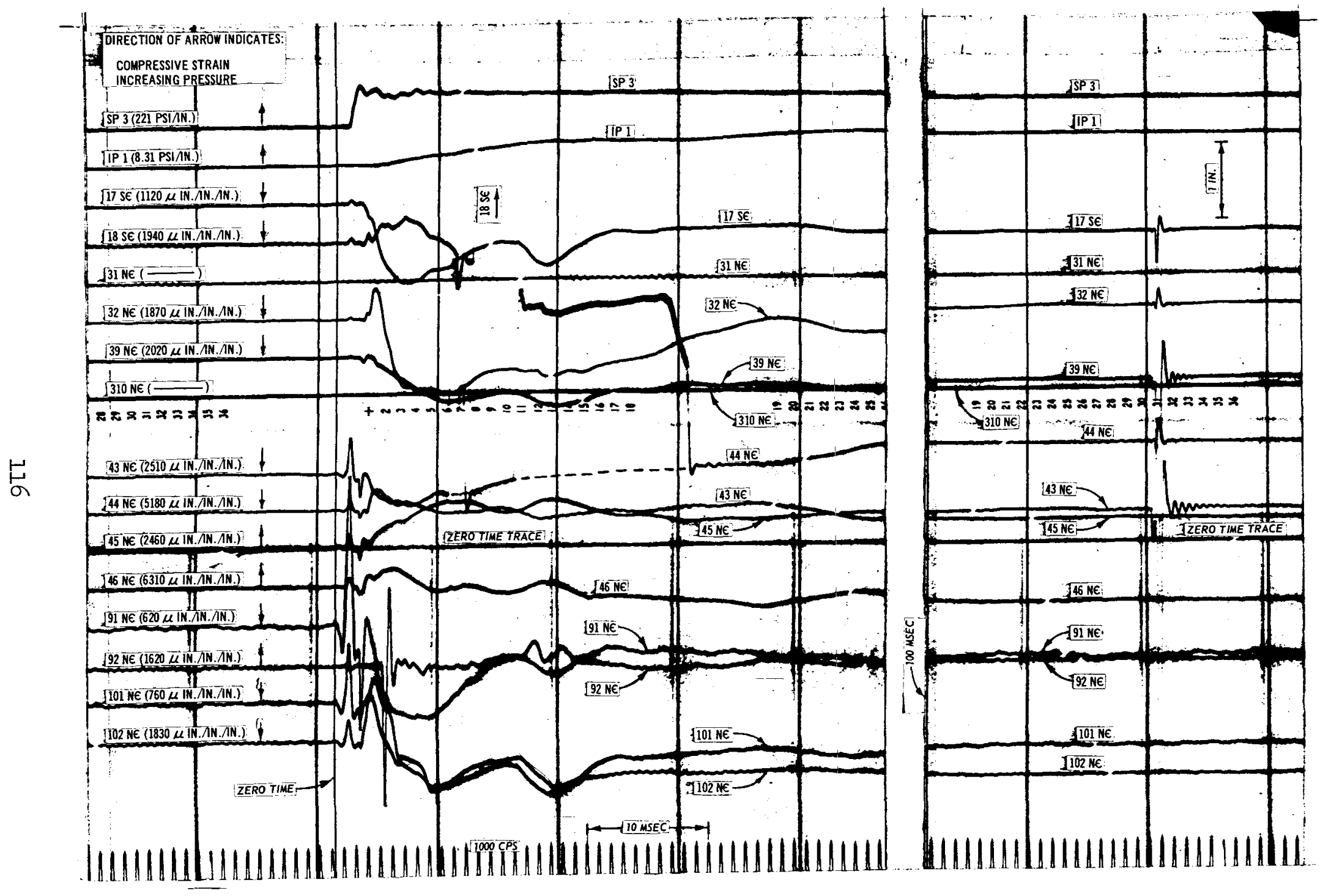

Figure B.15 Shot 3, oscillograph record from Recorder 5. 


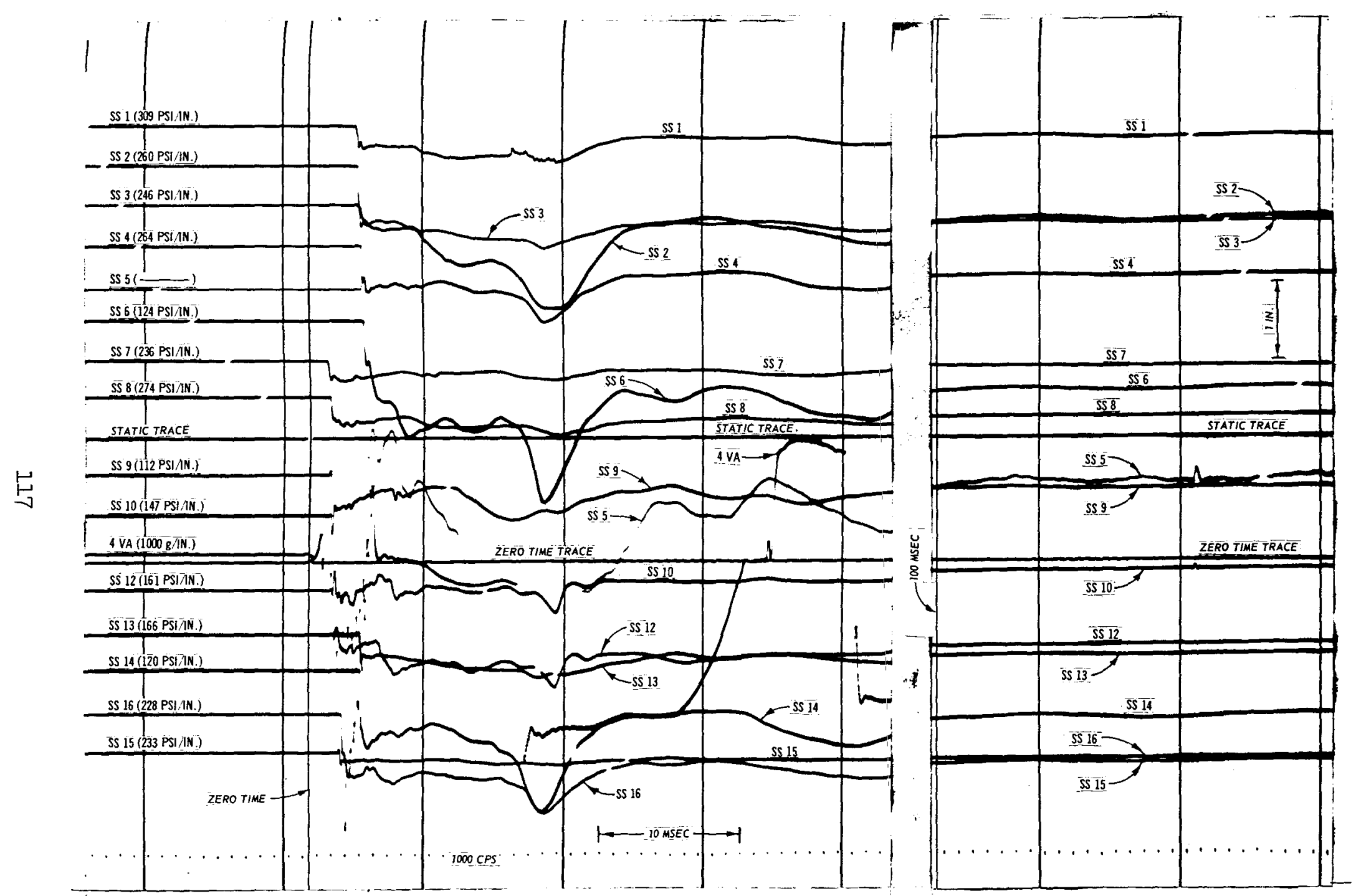

Figure B.16 Shot 3, oscillograph record from Recorder 6 . 

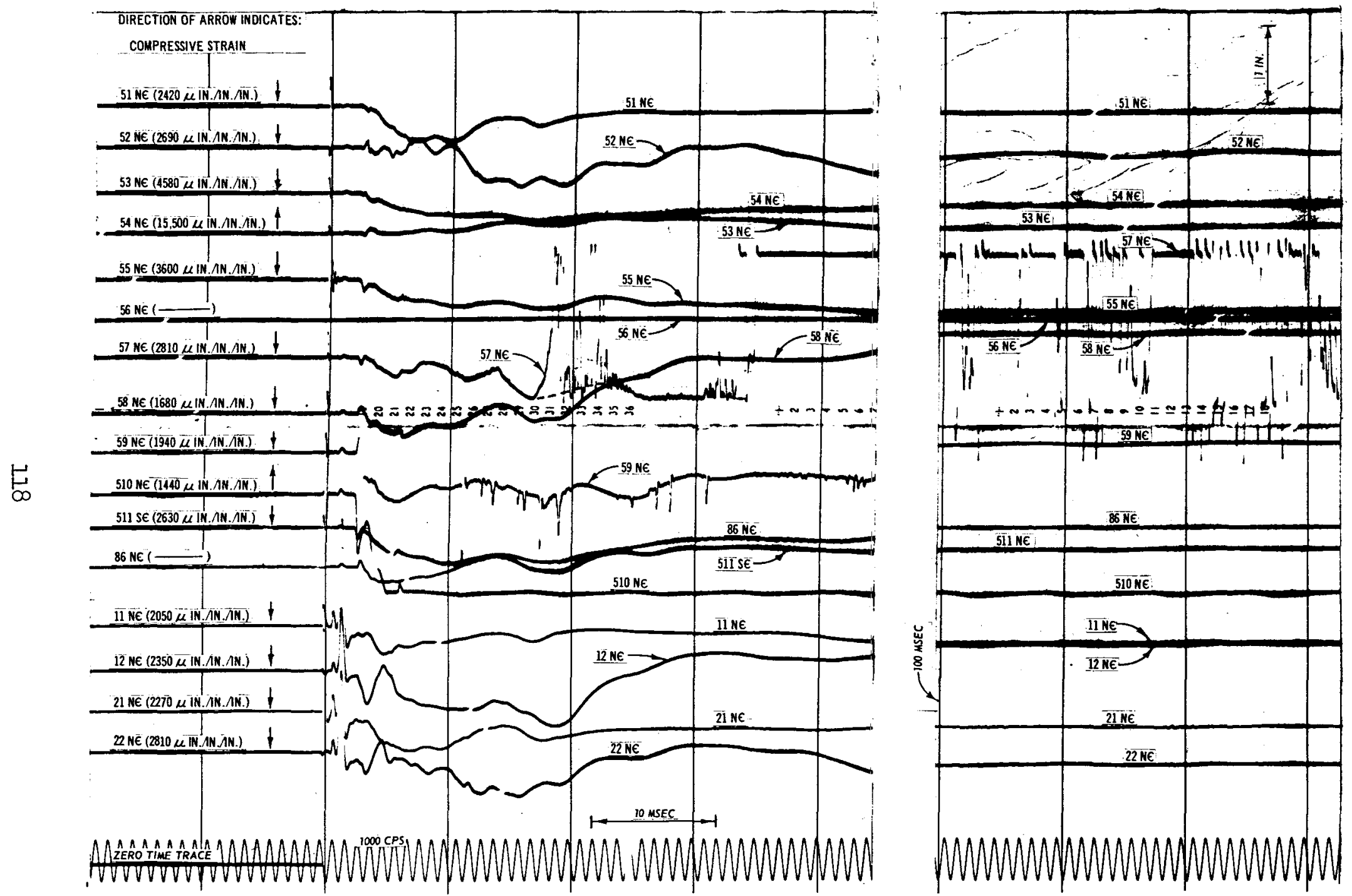

Figure B.17 Shot 4, oscillograph record from Recorder 1. 

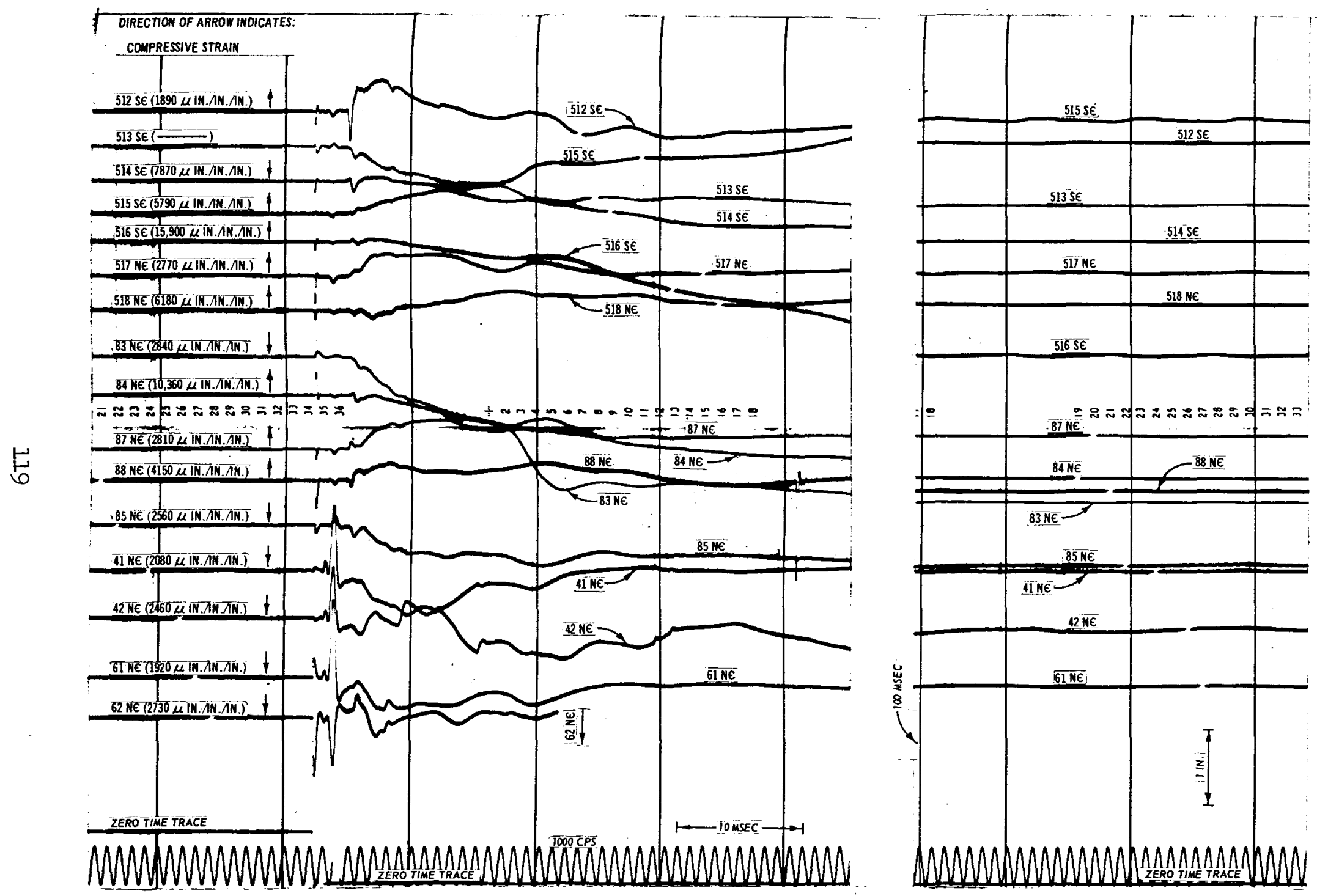

Figure B.18 Shot 4, oscillograph record from Recorder 2. 

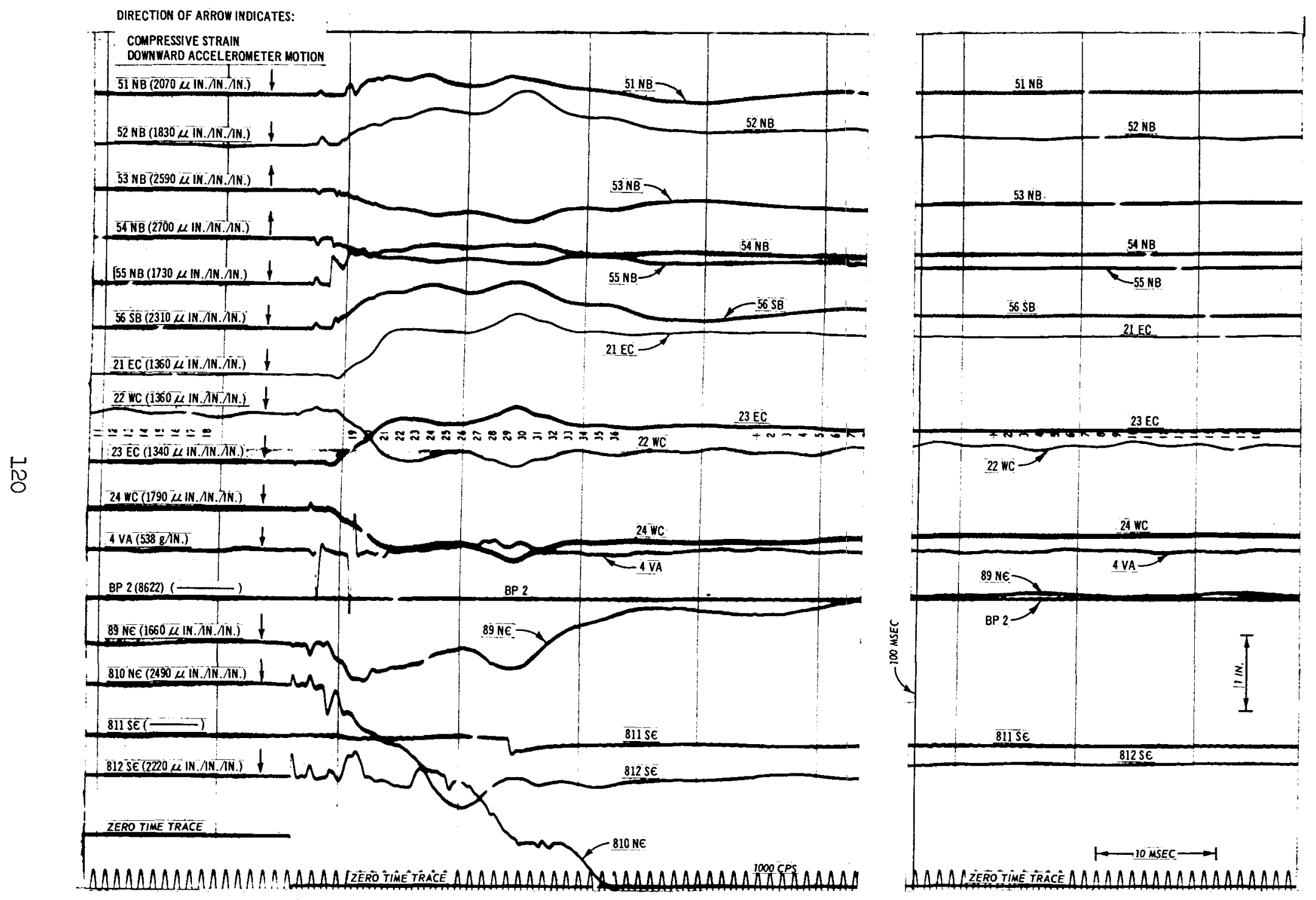

Figure B.19 Shot 4, oscillograph record from Recorder 3. 

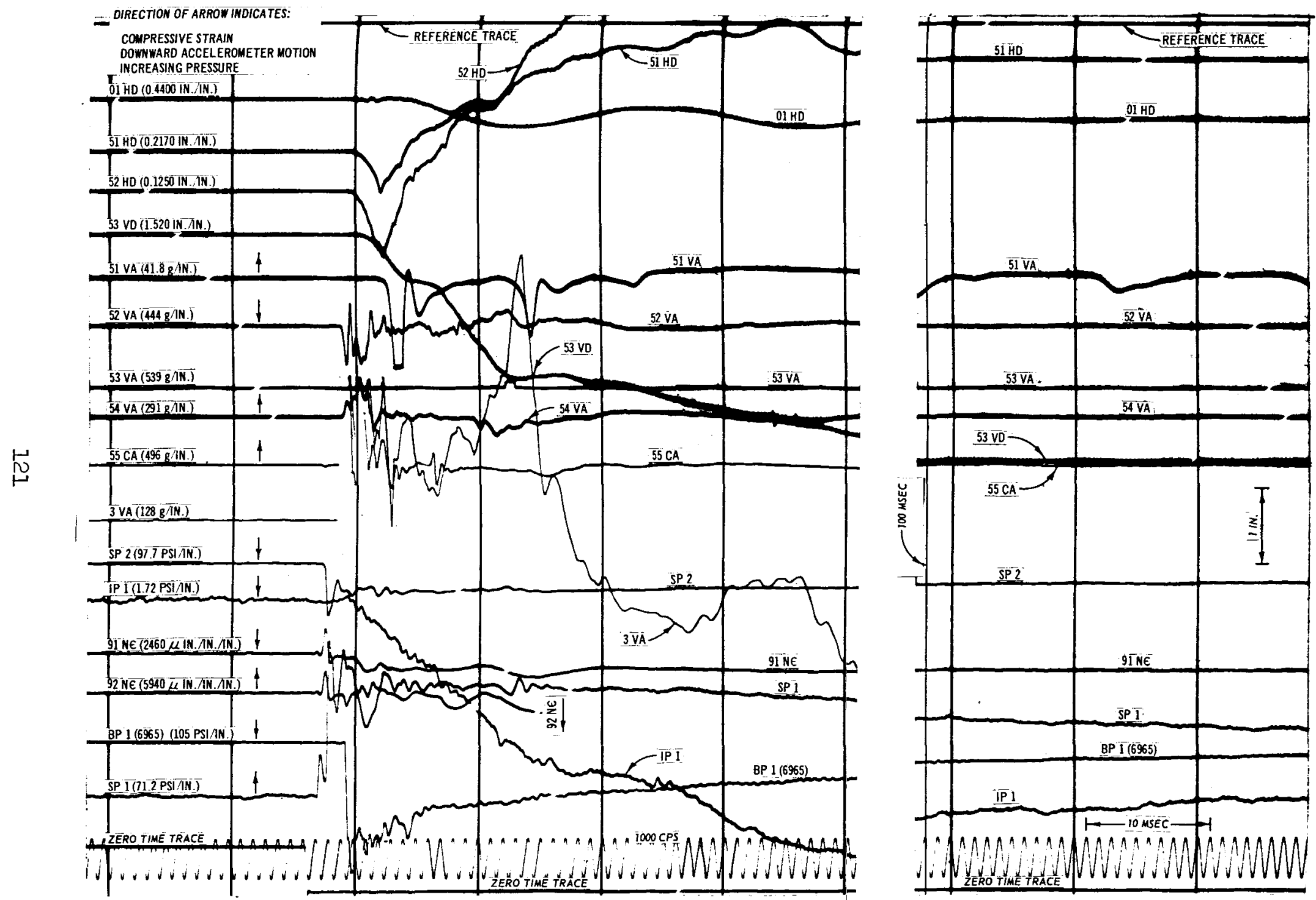

Figure B.20 Shot 4, oscillograph record from Recorder 4. 

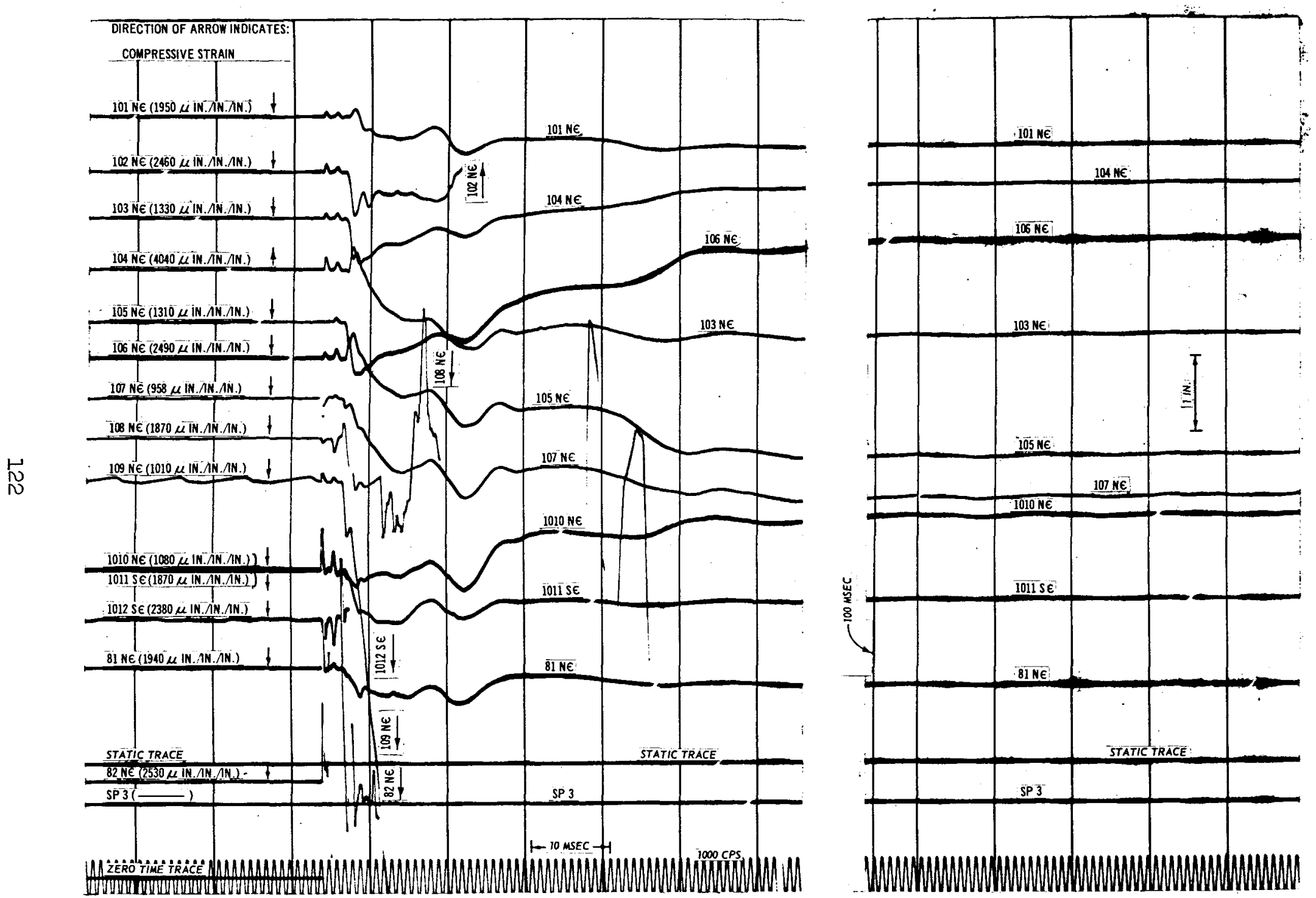

Figure B.21 Shot 4, oscillograph record from Recorder 5. 


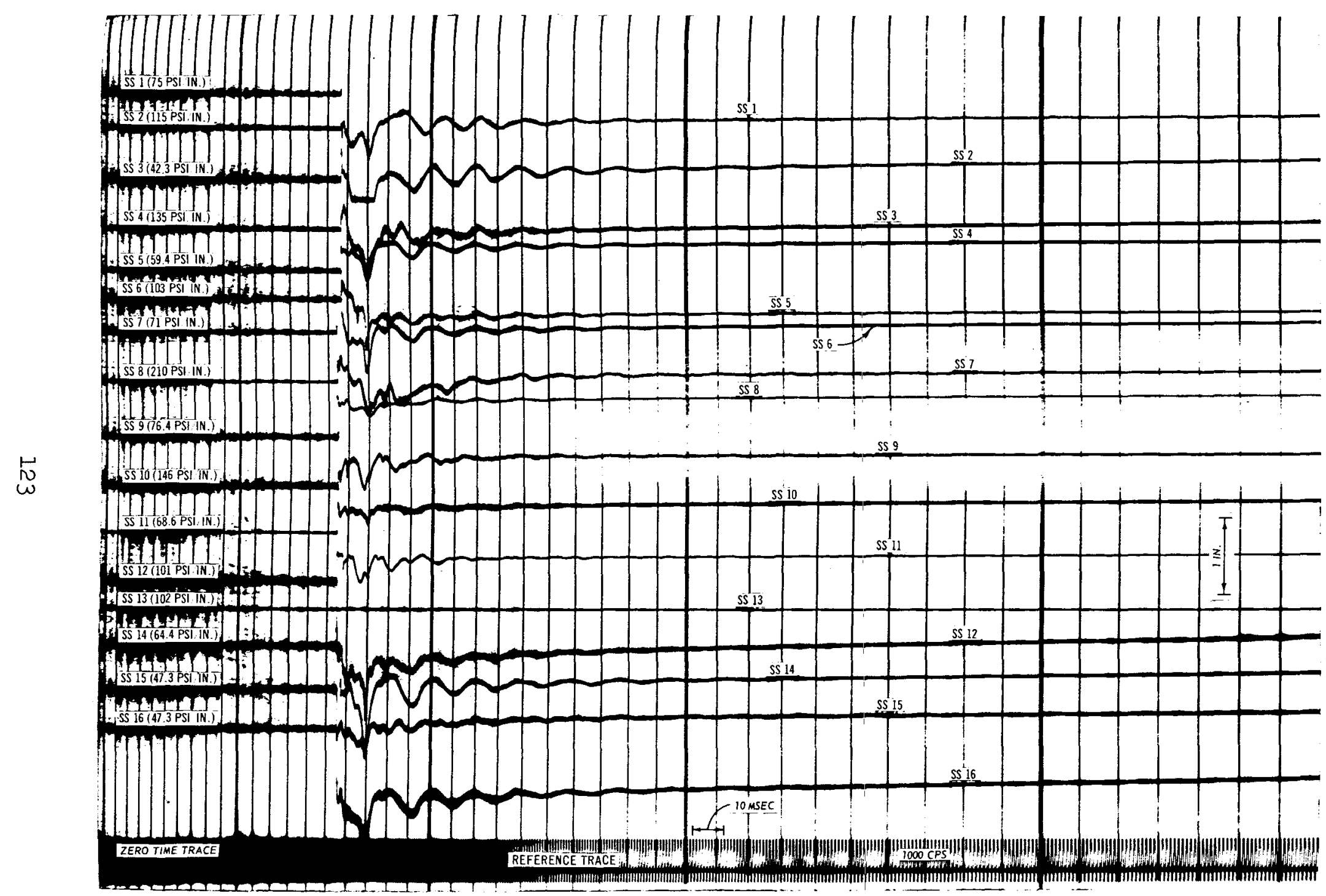

Figure B.22 Shot 4, oscillograph record from Recorder 6 . 

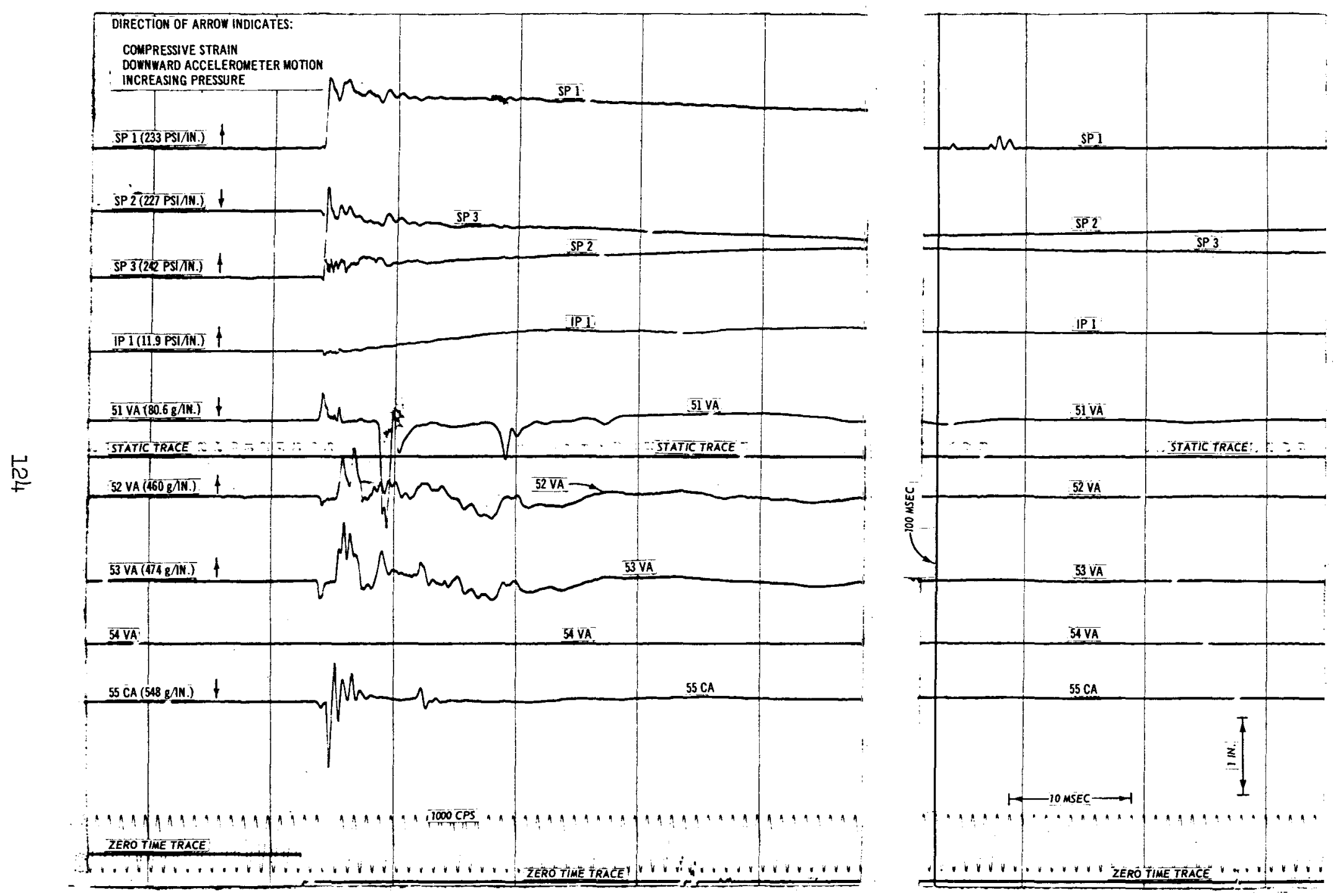

Figure B.23 Shot 5, oscillograph record from Recorder 1 . 

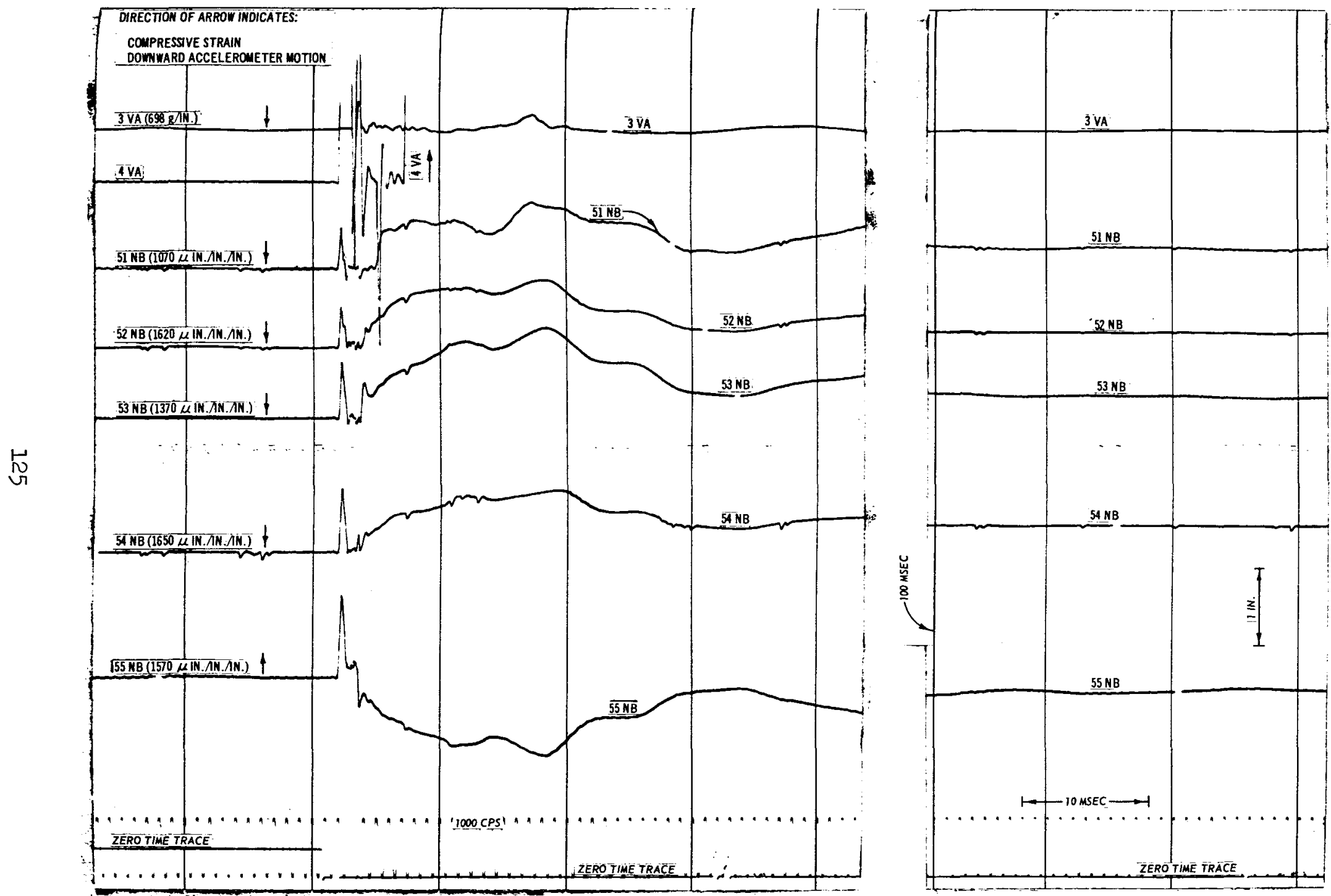

Figure B.24 Shot 5, oscillograph record from Recorder 2. 


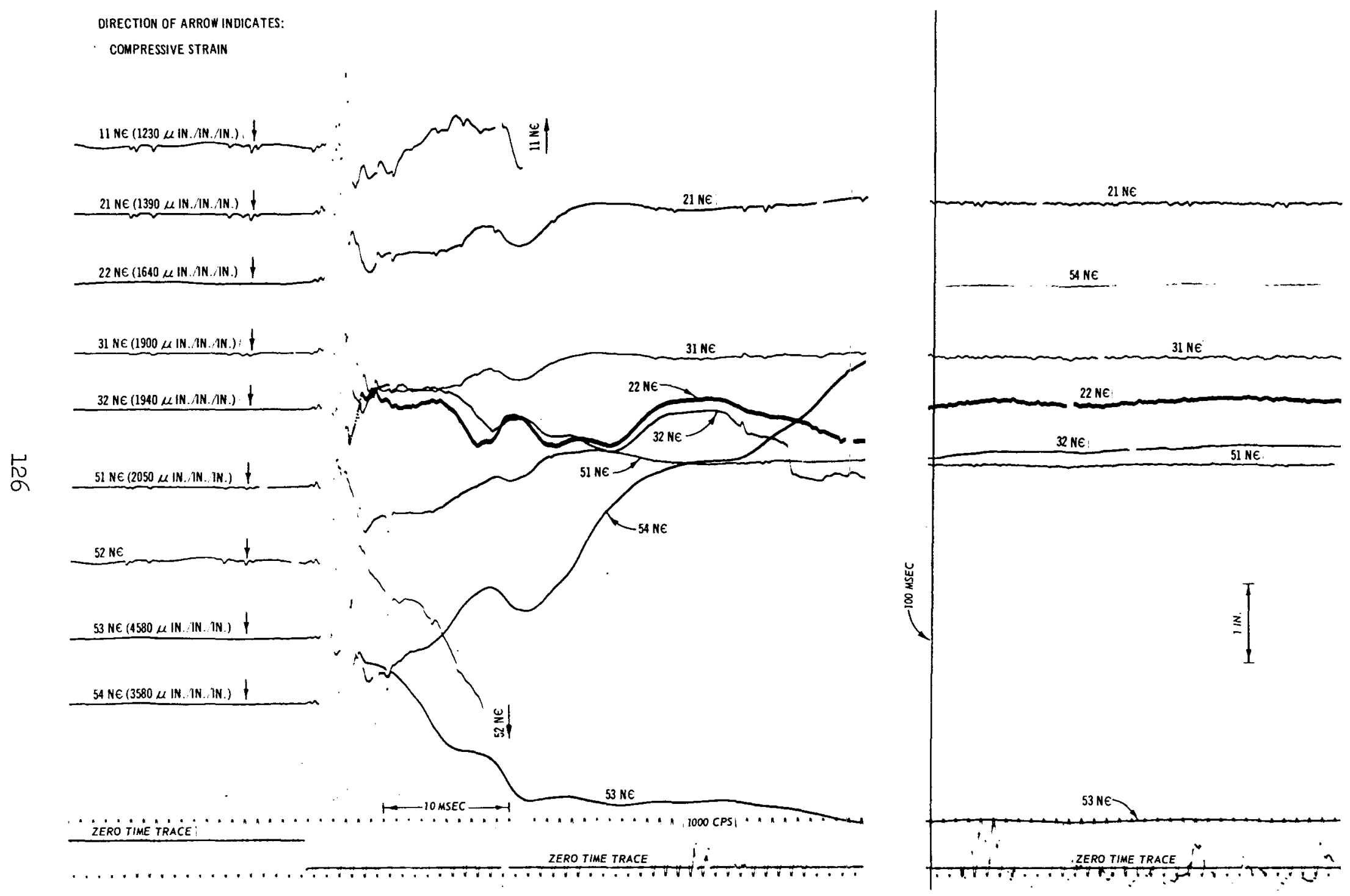

Figure B.25 Shot 5, oscillograph record from Recorder 3. 


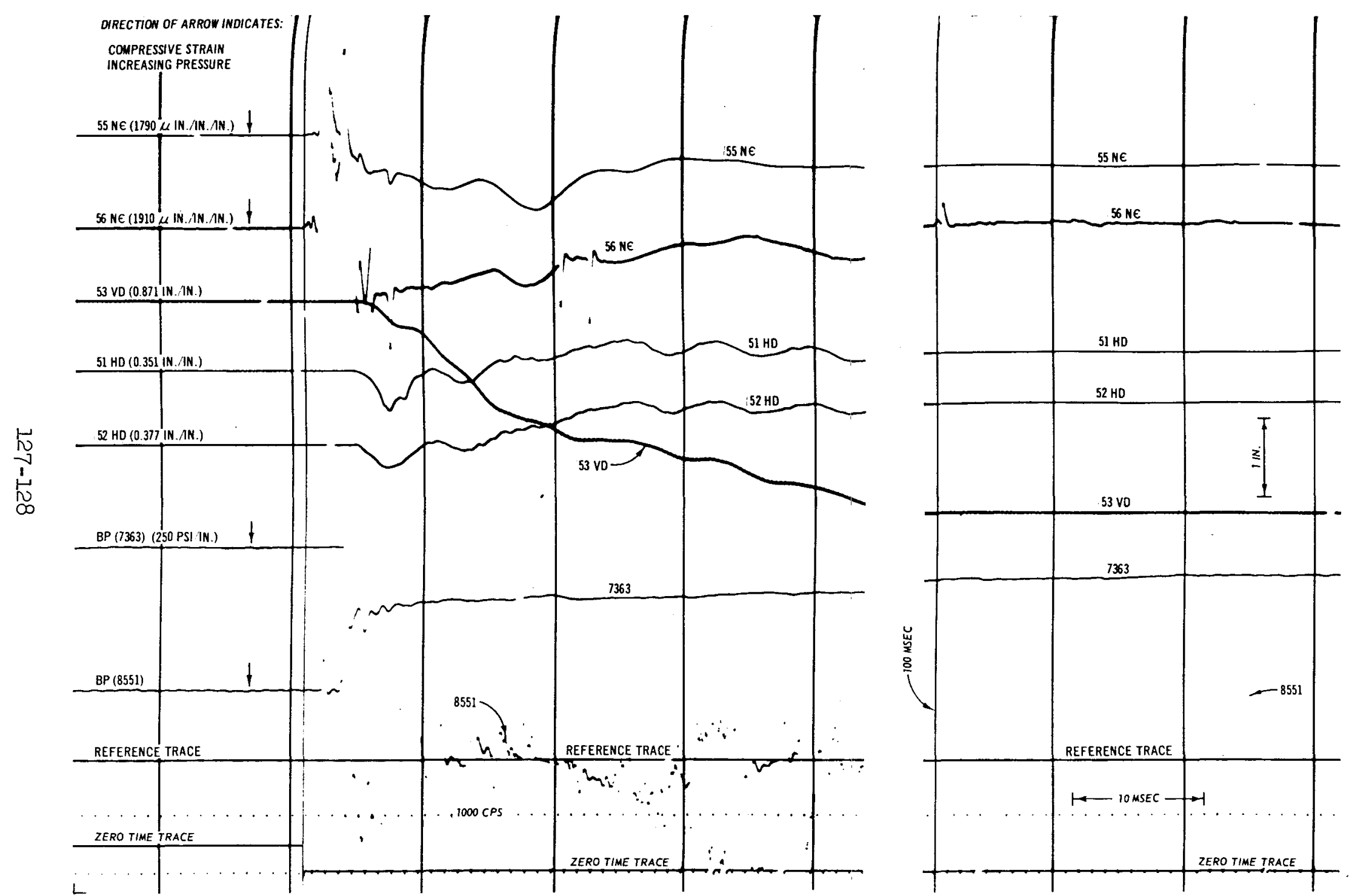

Figure B.26 Shot 5, oscillograph record from Recorder 4. 
APPENDIX C

COMPUTED DATA 

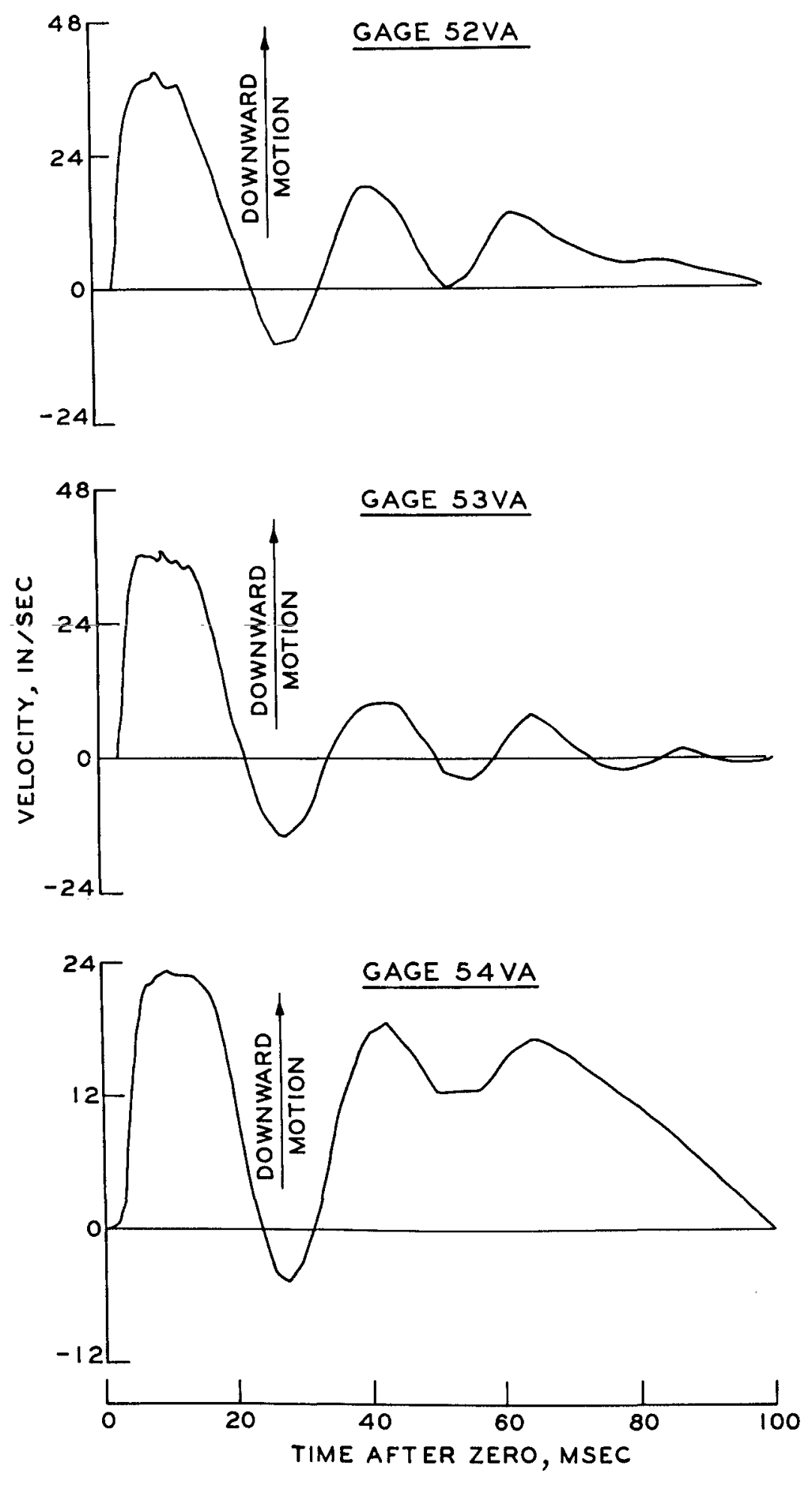

Figure C.I Velocity data, Shot 1. 


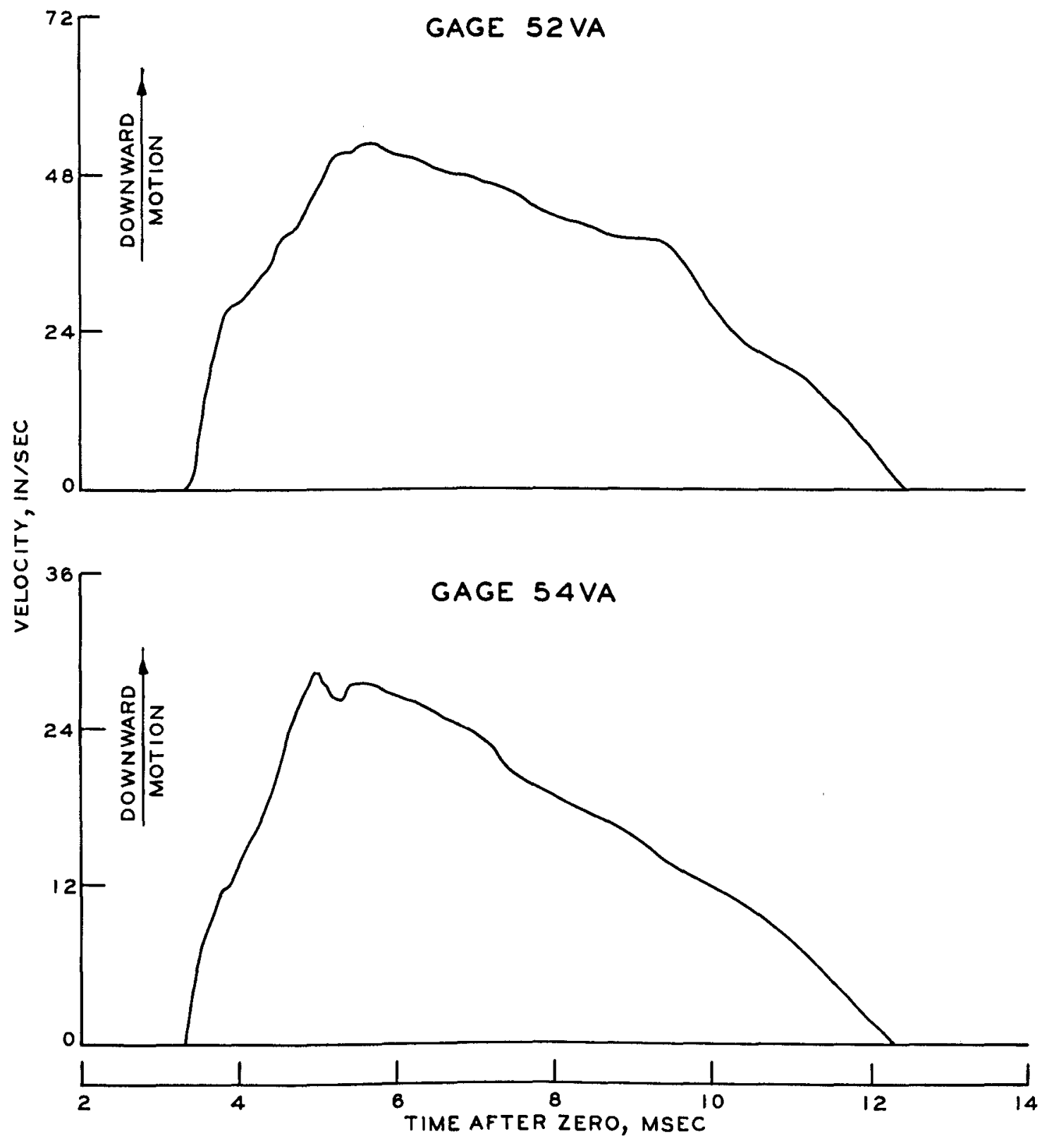

Figure C.2 Velocity data, Shot 2. 

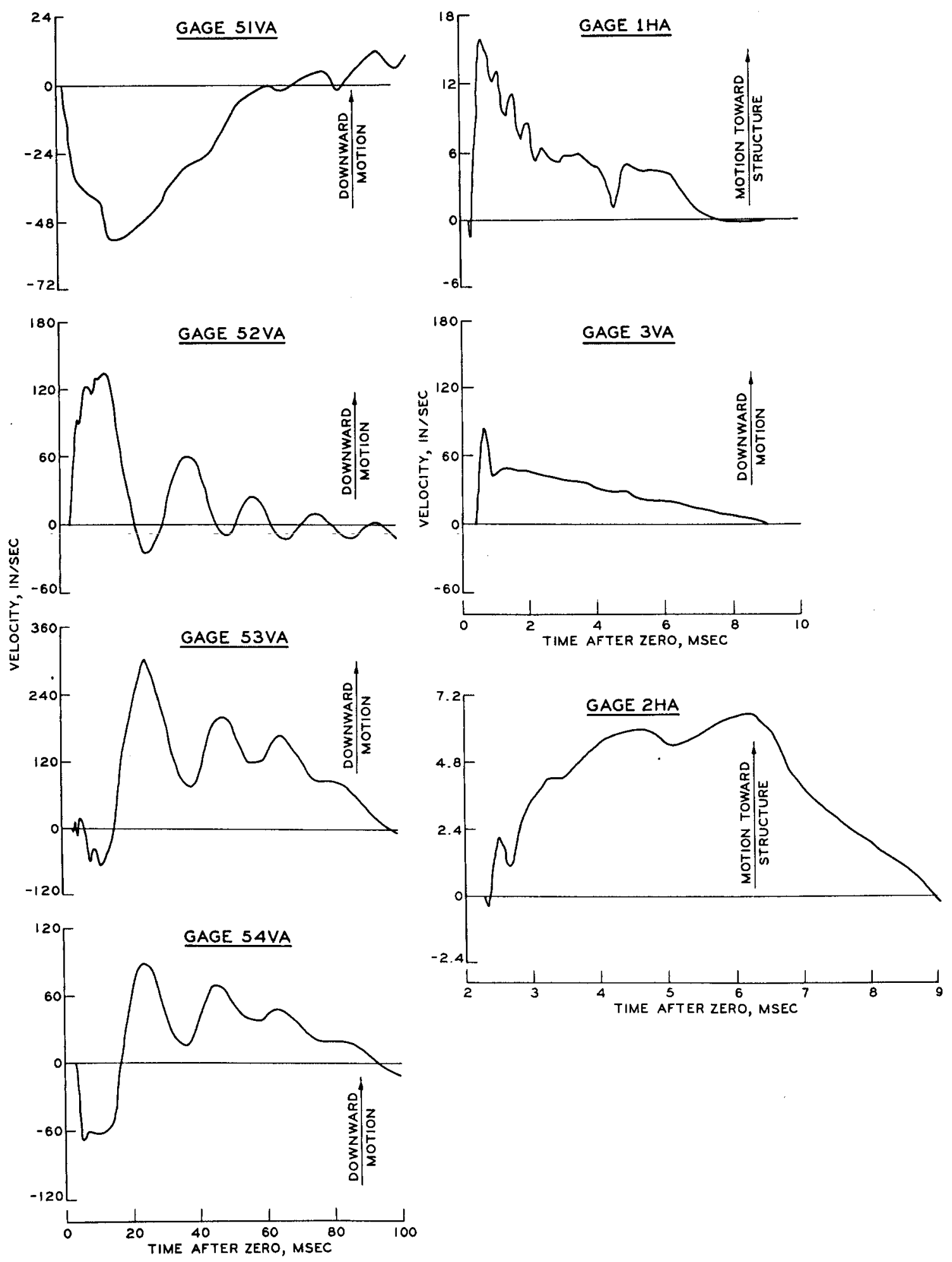

Figure C.3 Velocity data, Shot 3 . 

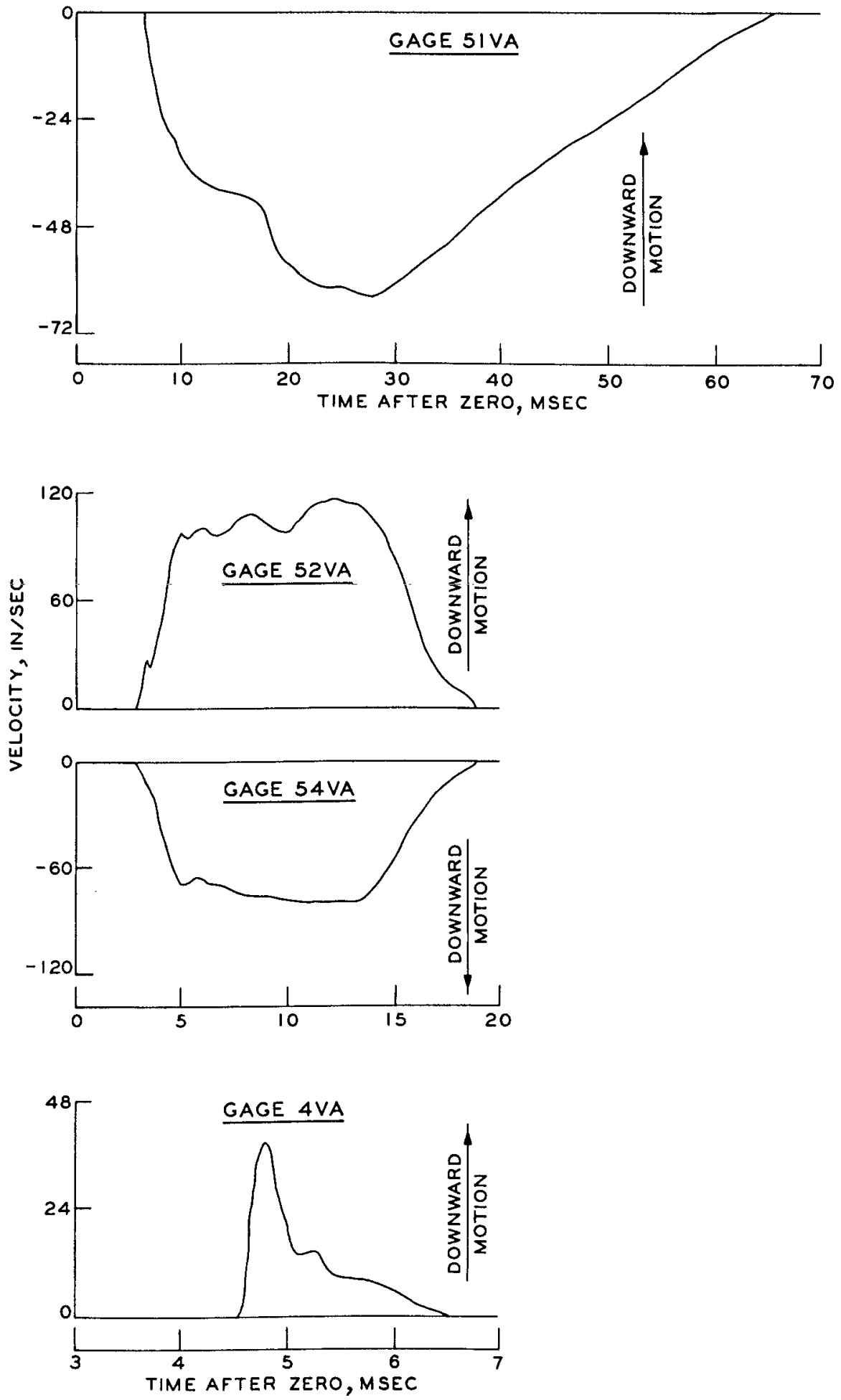

Figure C.4 Velocity data, shot 4 . 

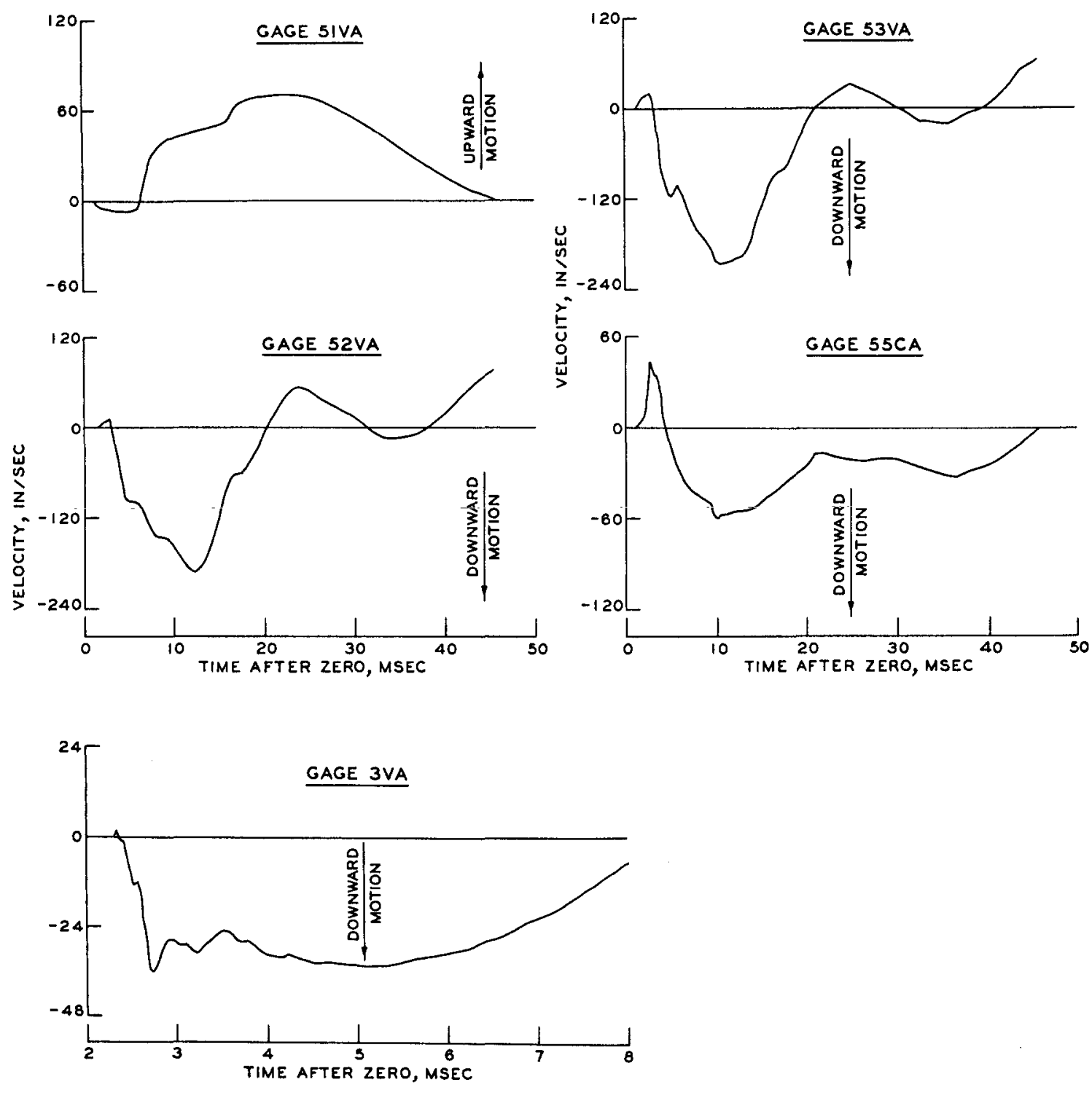

Figure C.5 Velocity data, Shot 5 . 

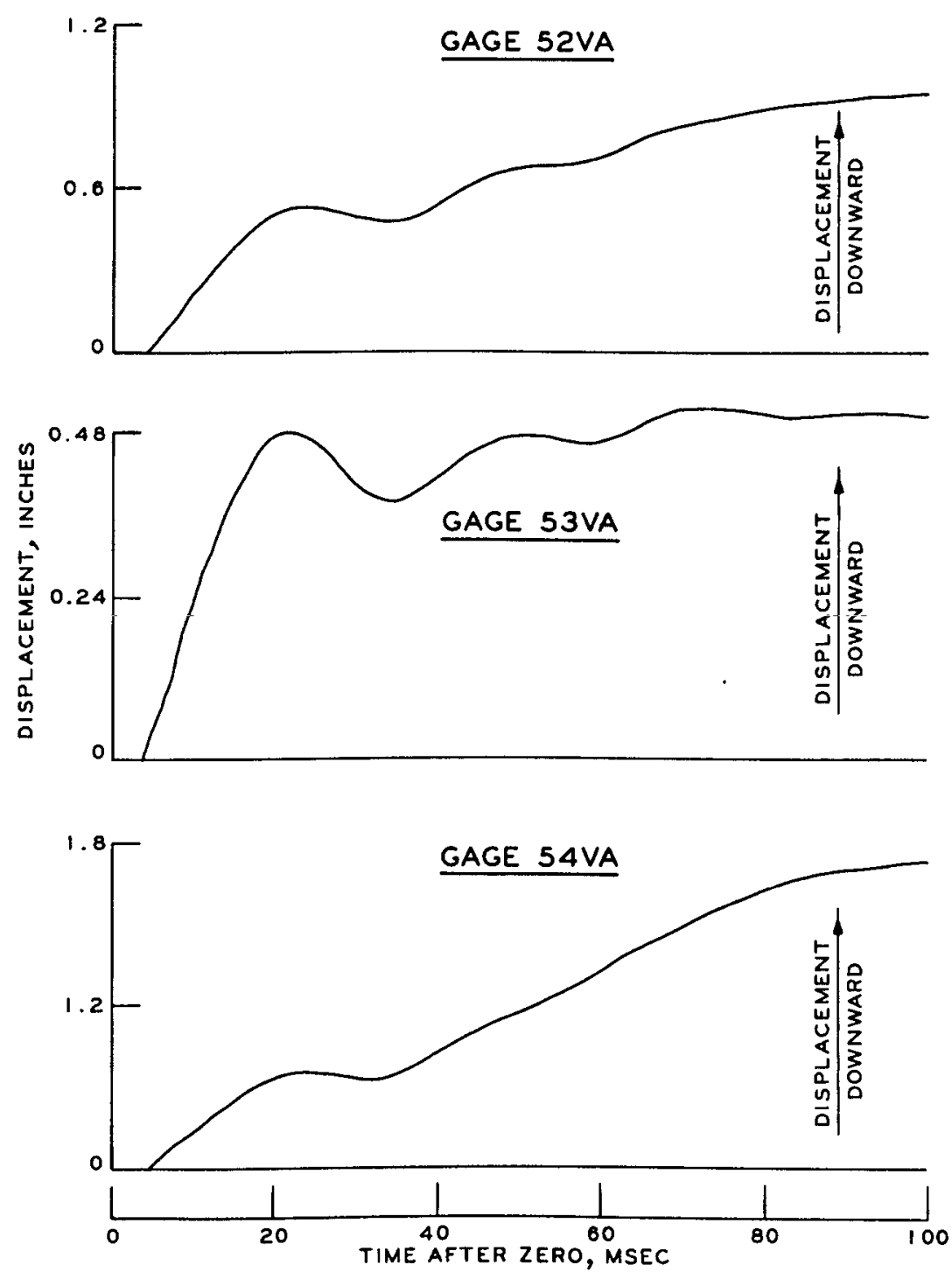

Figure C.6 Displacement data, Shot 1 . 


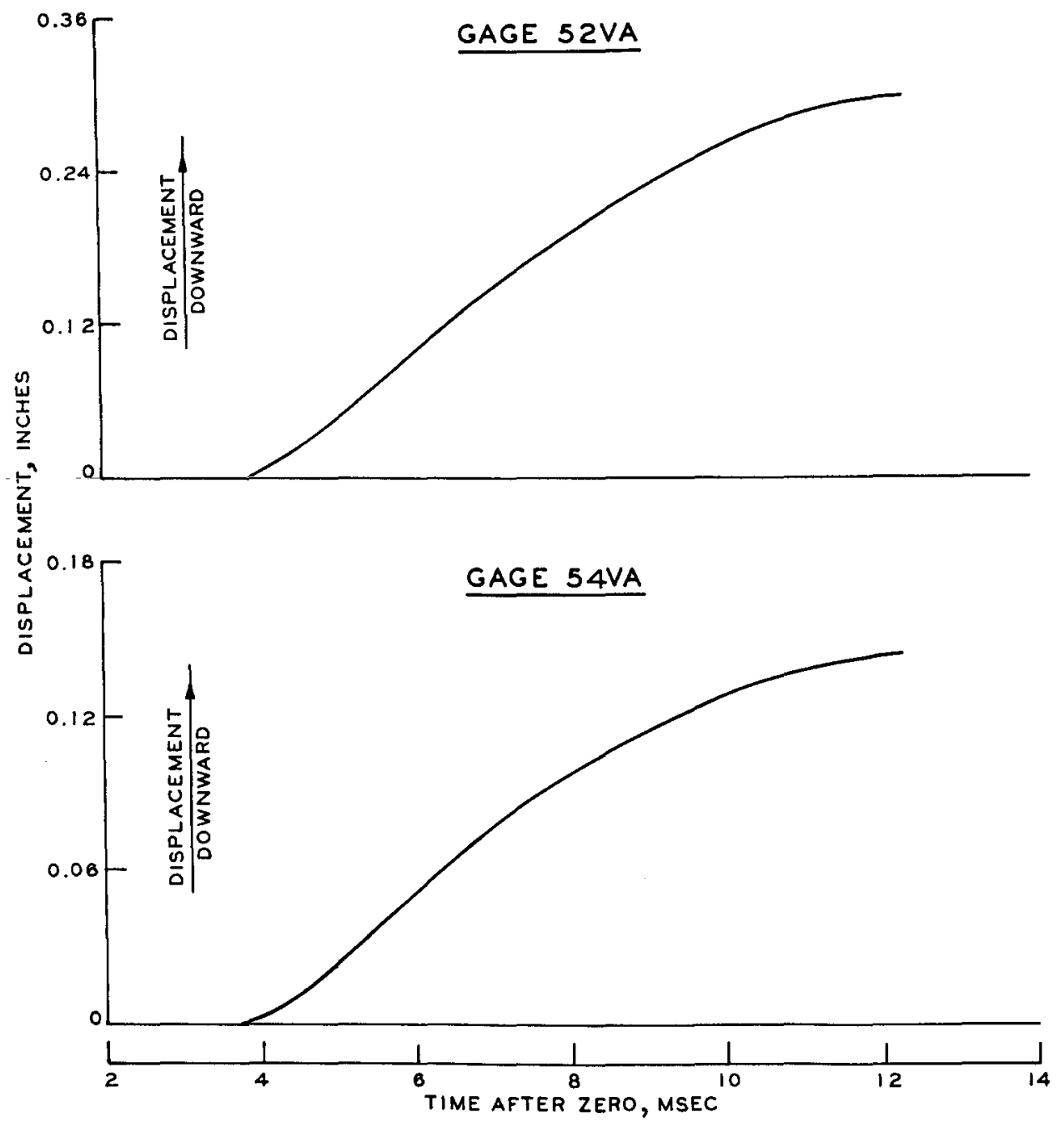

Figure C.7 Displacement data, Shot 2 . 

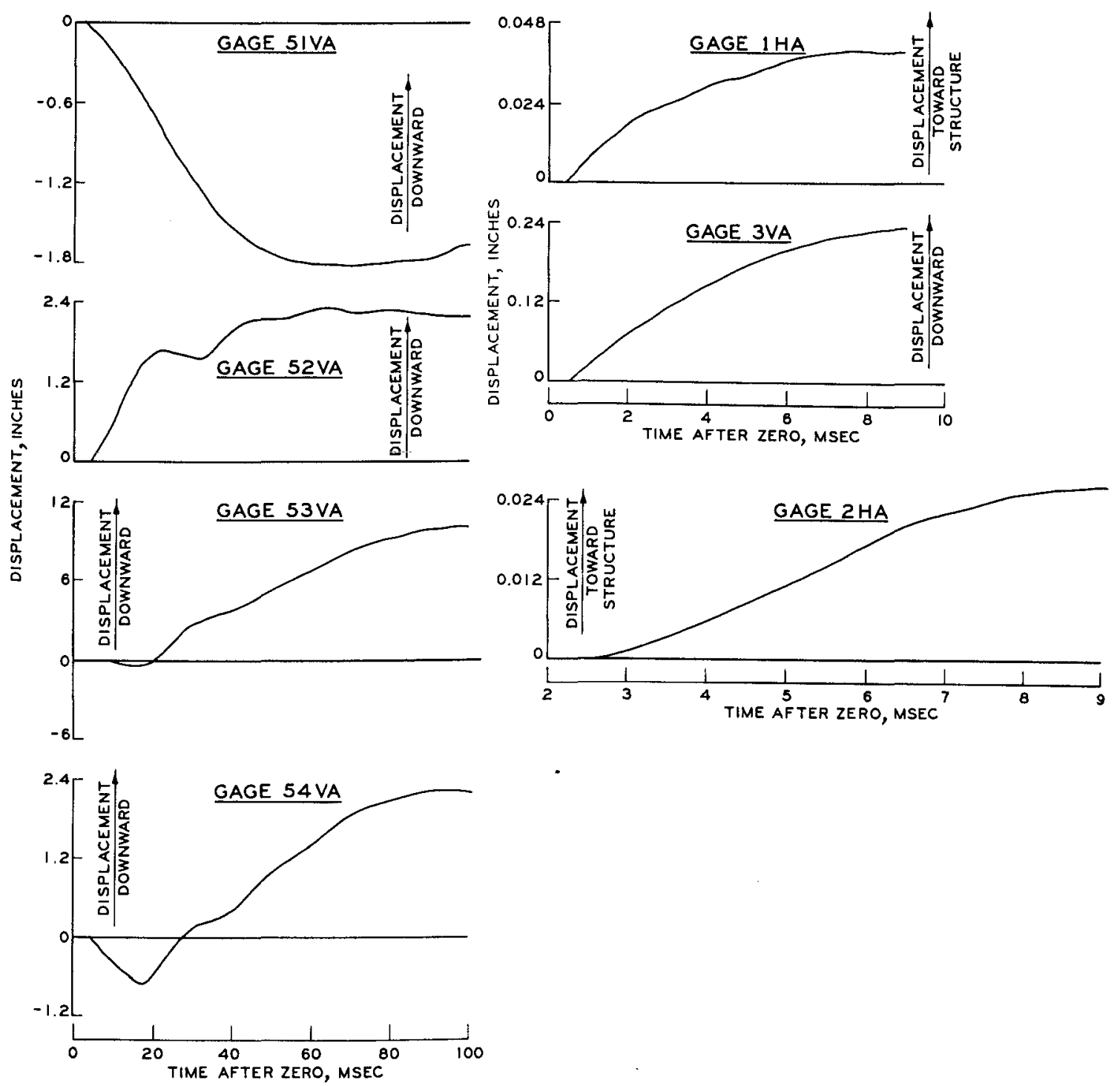

Figure C.8 Displacement data, Shot 3. 

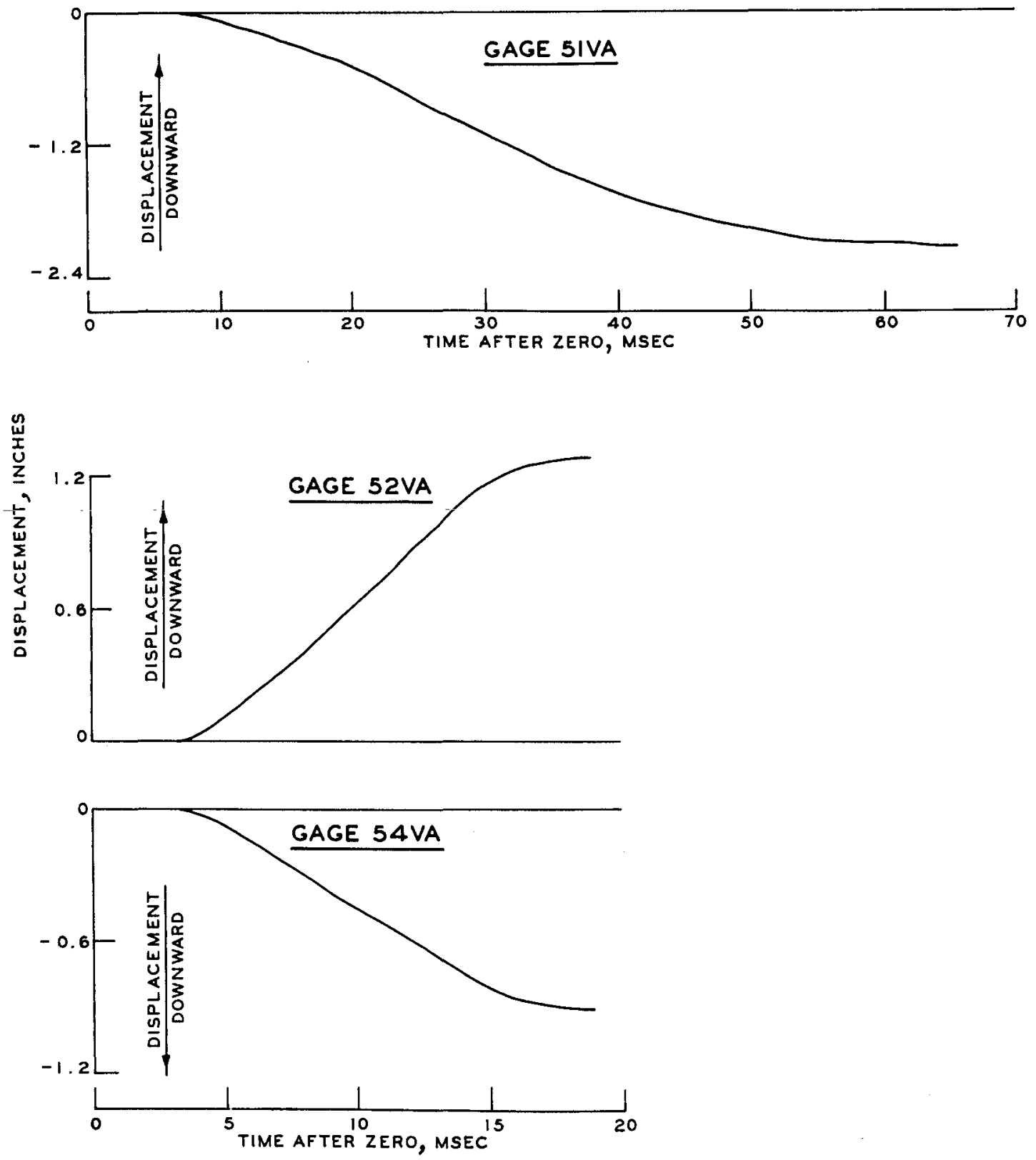

Figure C.9 Displacement data, Shot 4 . 

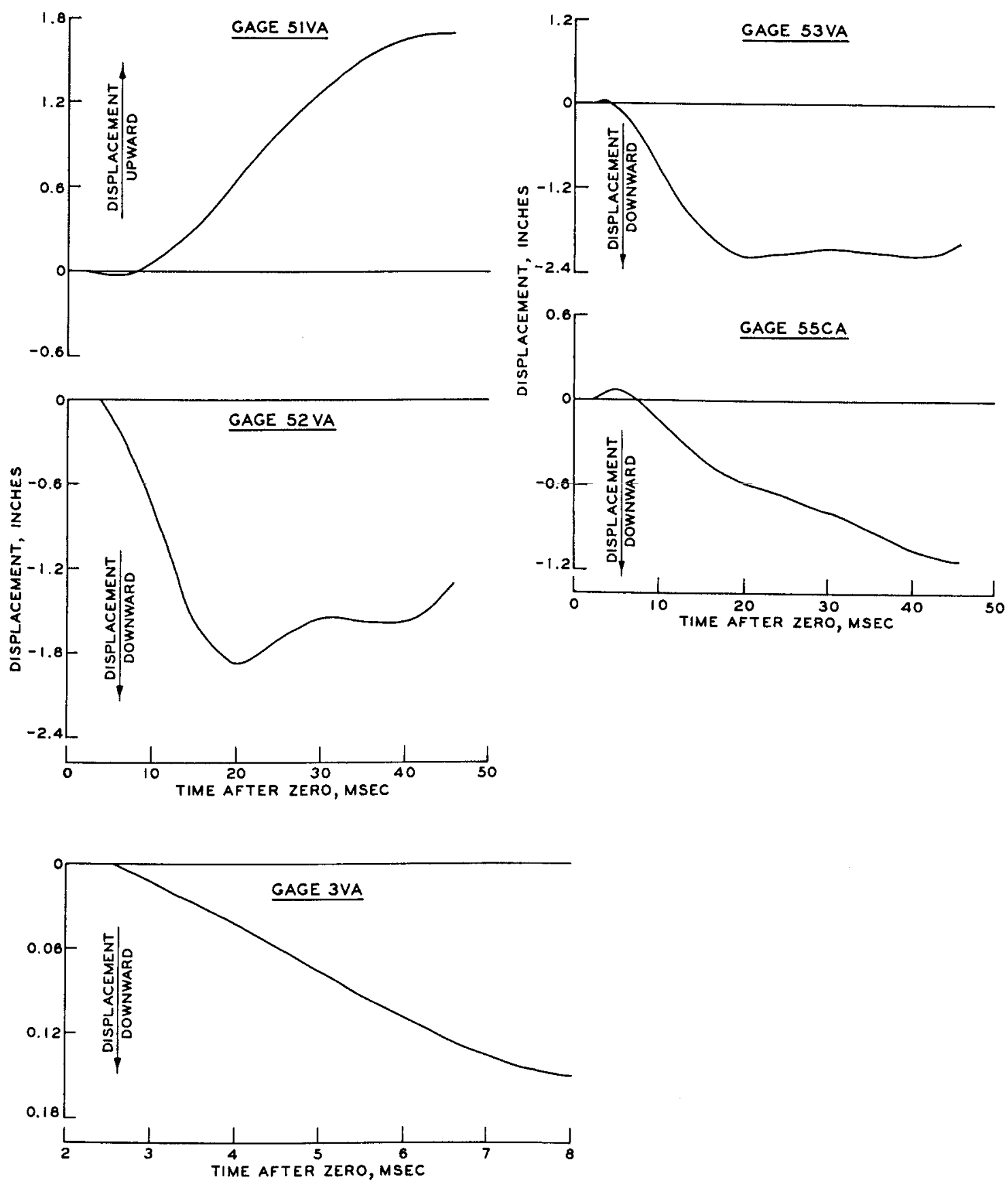

Figure C.10 Displacement data, Shot 5 . 

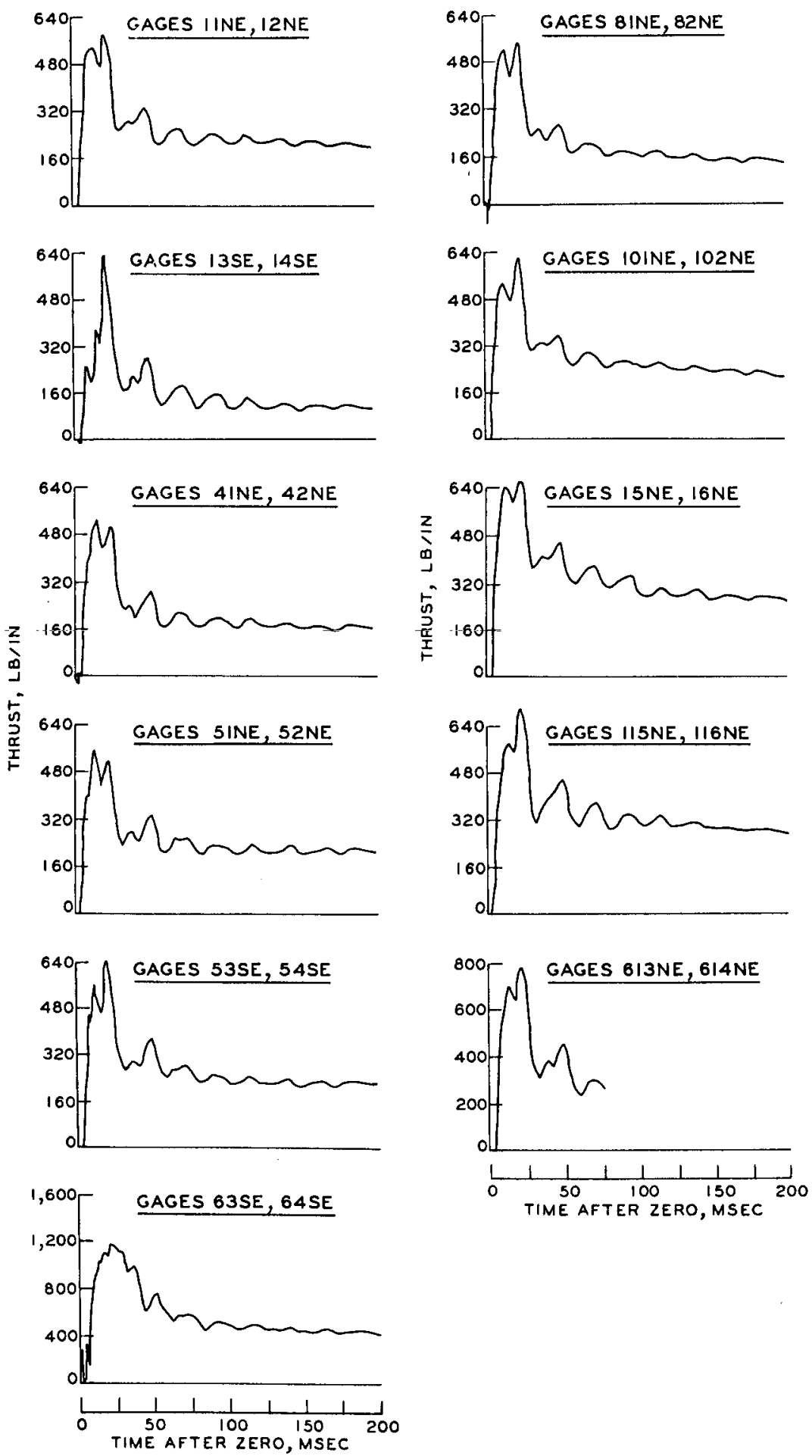

Figure C.II Thrust data, Shot 1. 

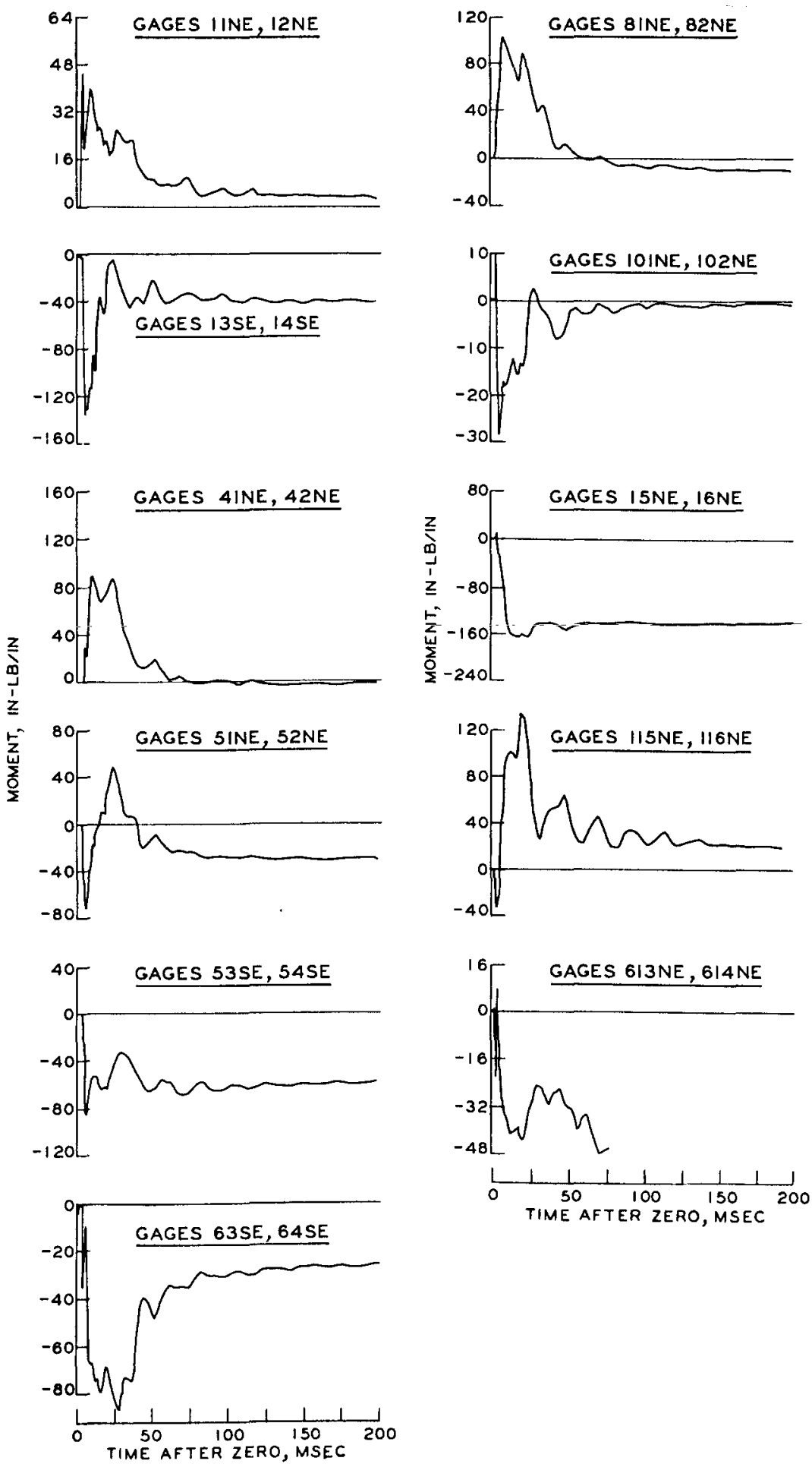

Figure C.12 Moment data, Shot 1. 

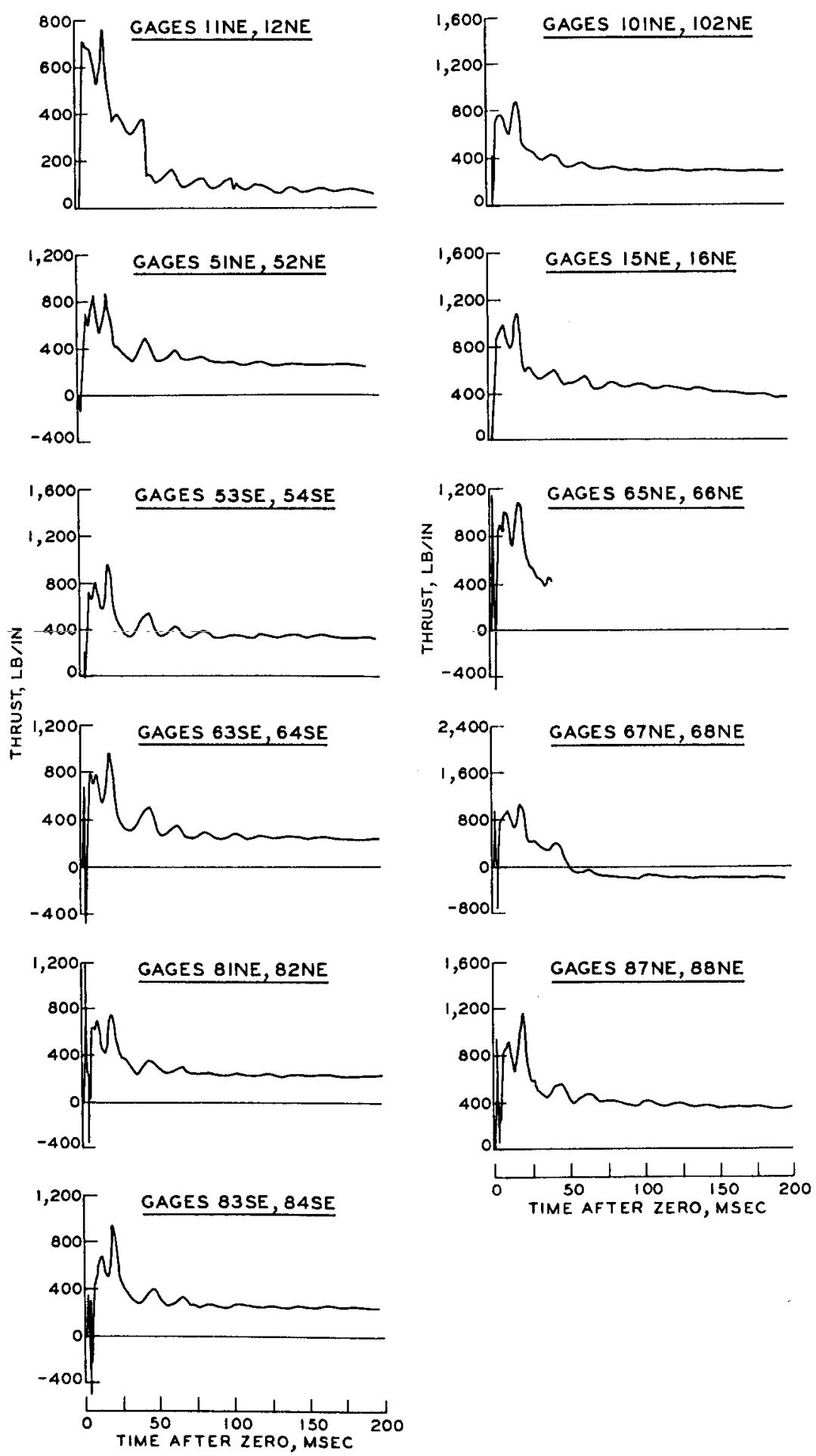

Figure C.13 Thrust data, Shot 2. 

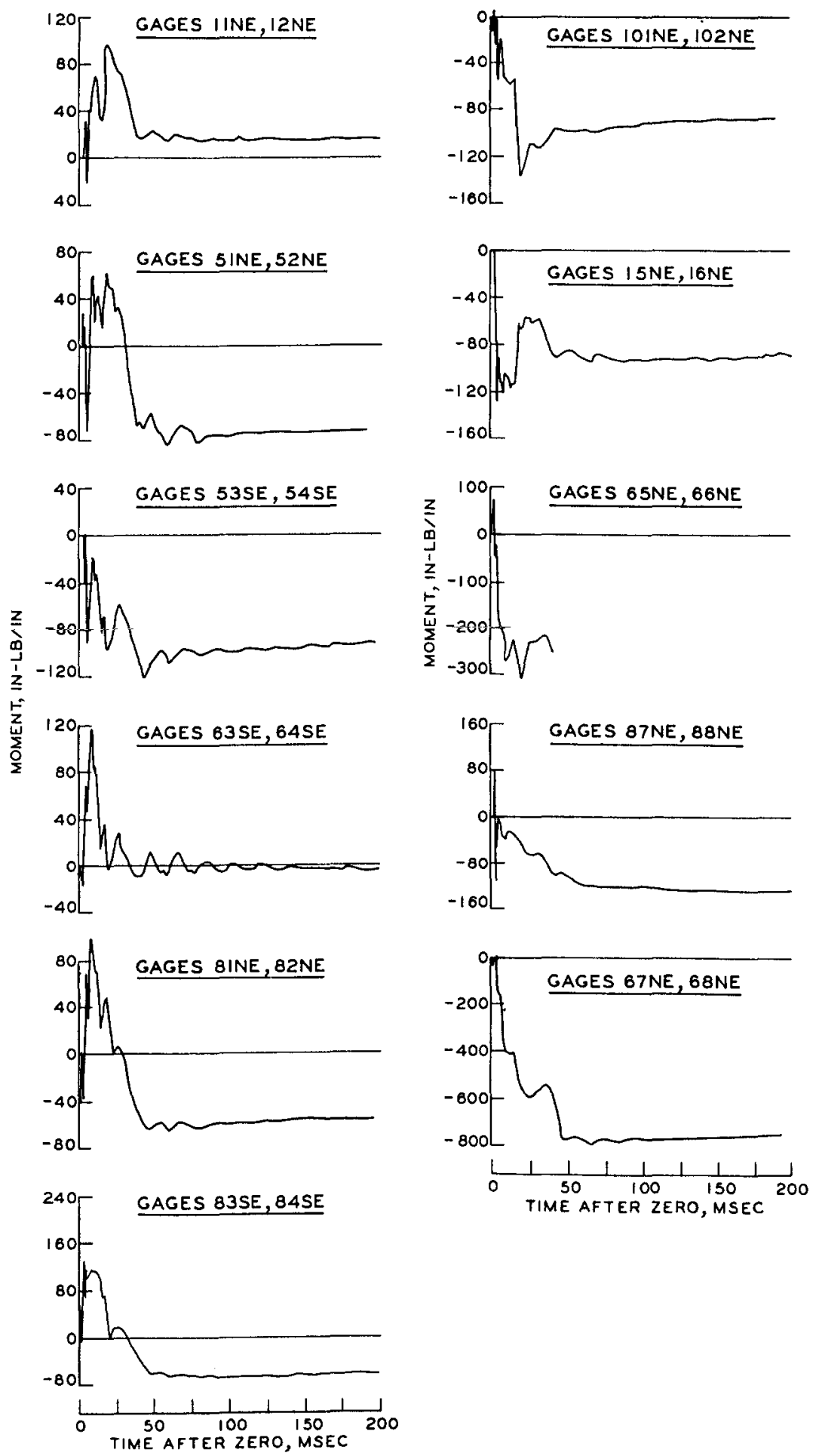

Figure C.14 Moment data, Shot 2. 

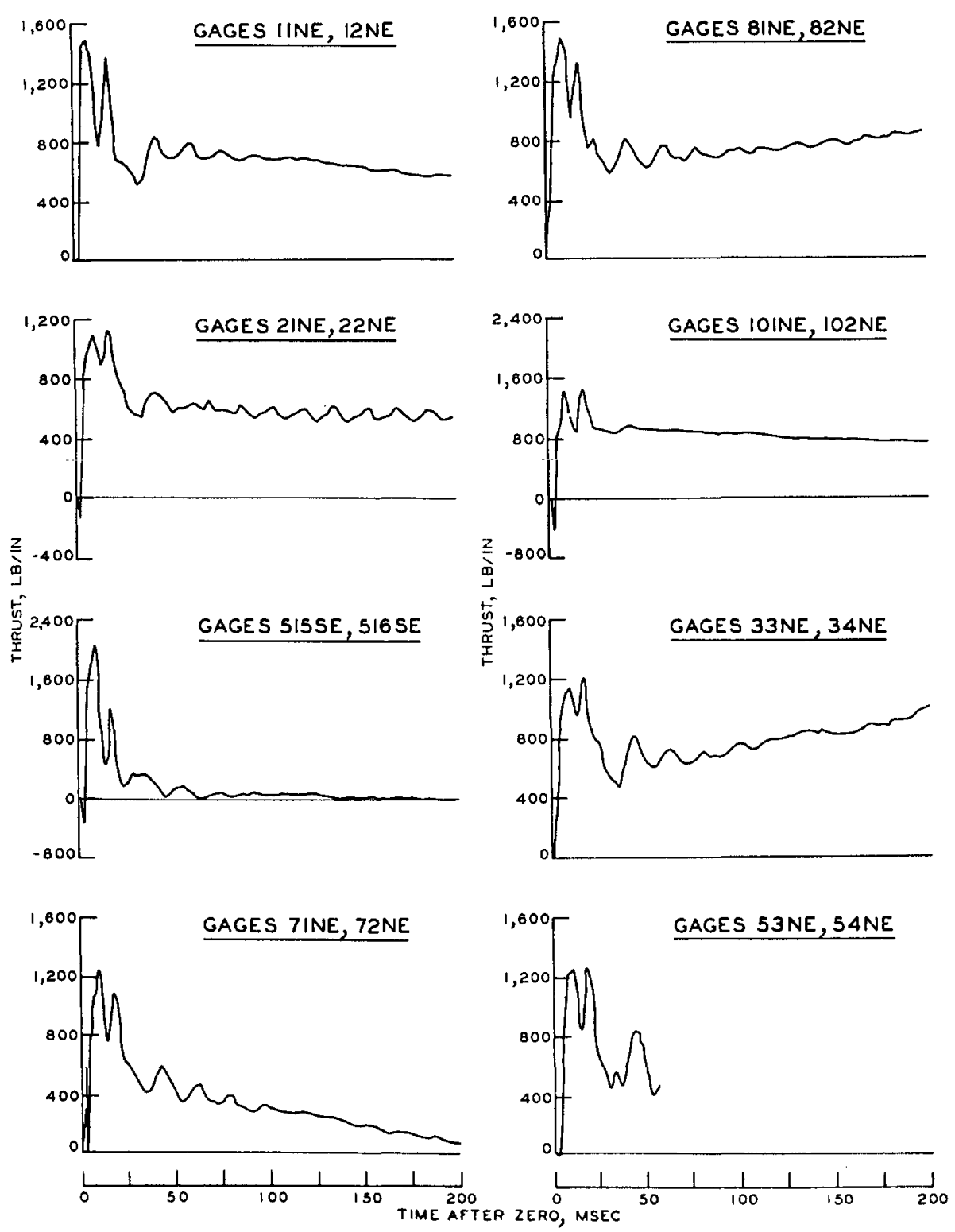

Figure C.15 Thrust data, Shot 3 (Sheet 1 of 2). 

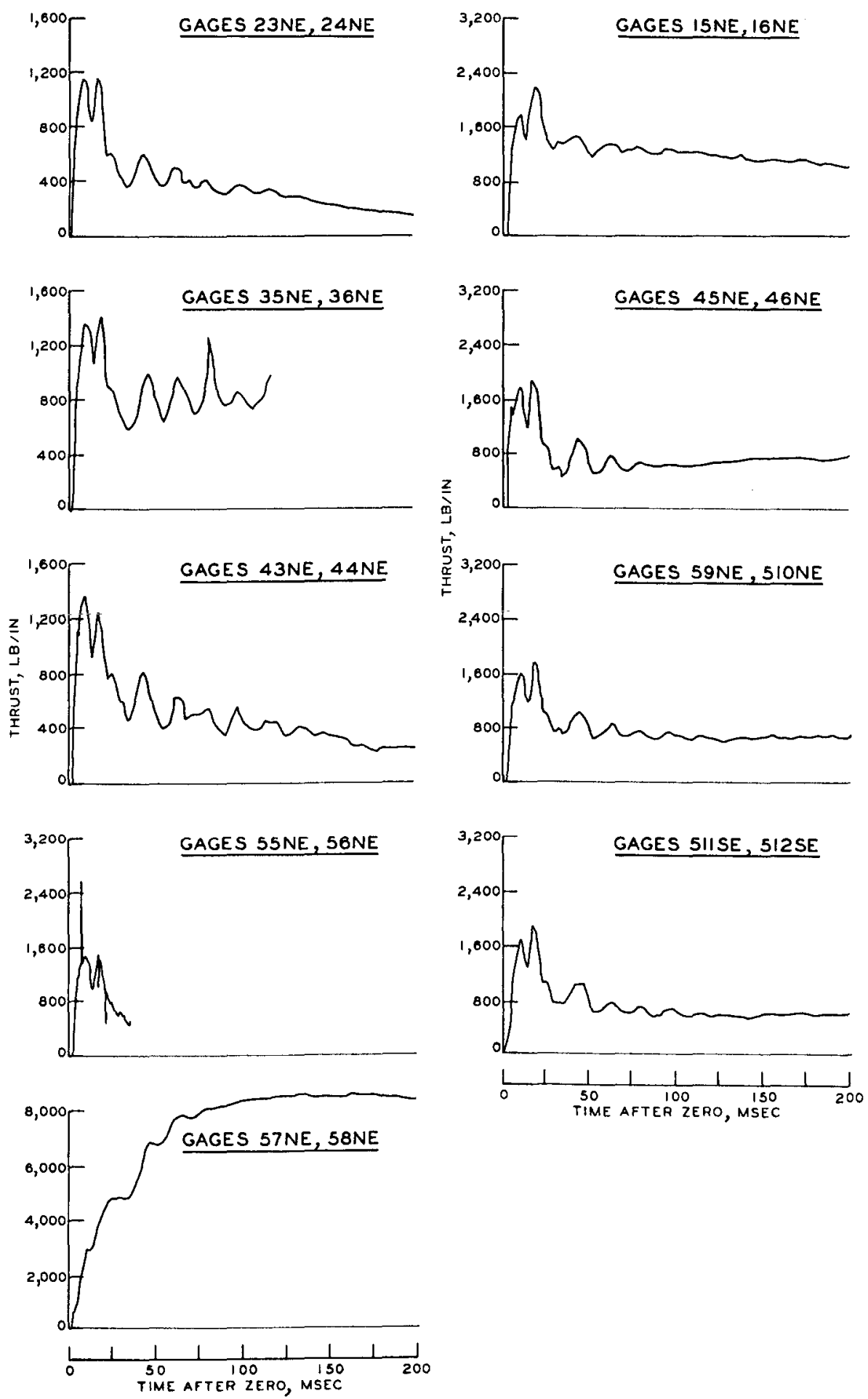

Figure C.15 (Sheet 2 of 2). 

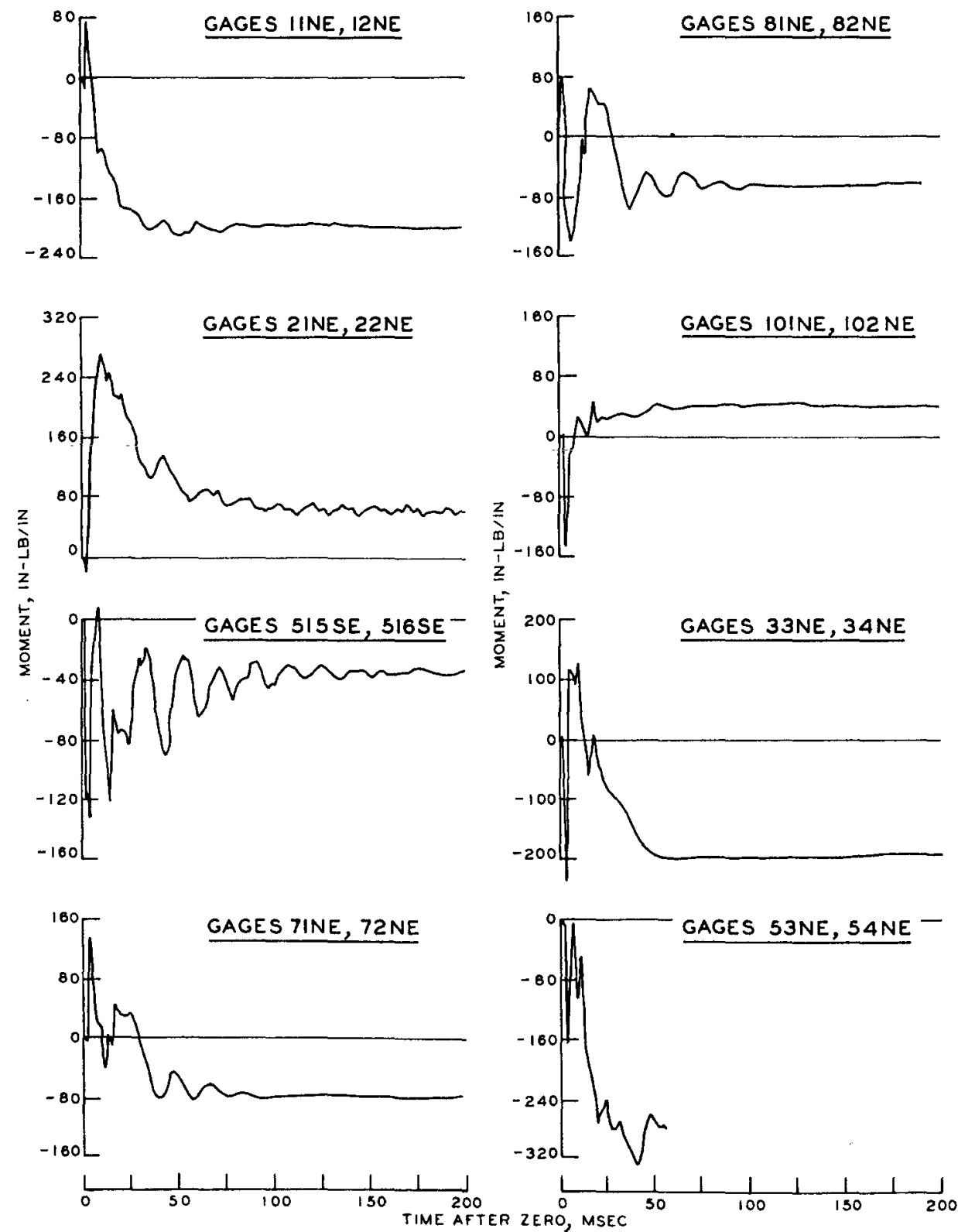

Figure C.16 Moment data, Shot 3 (Sheet 1 of 2). 

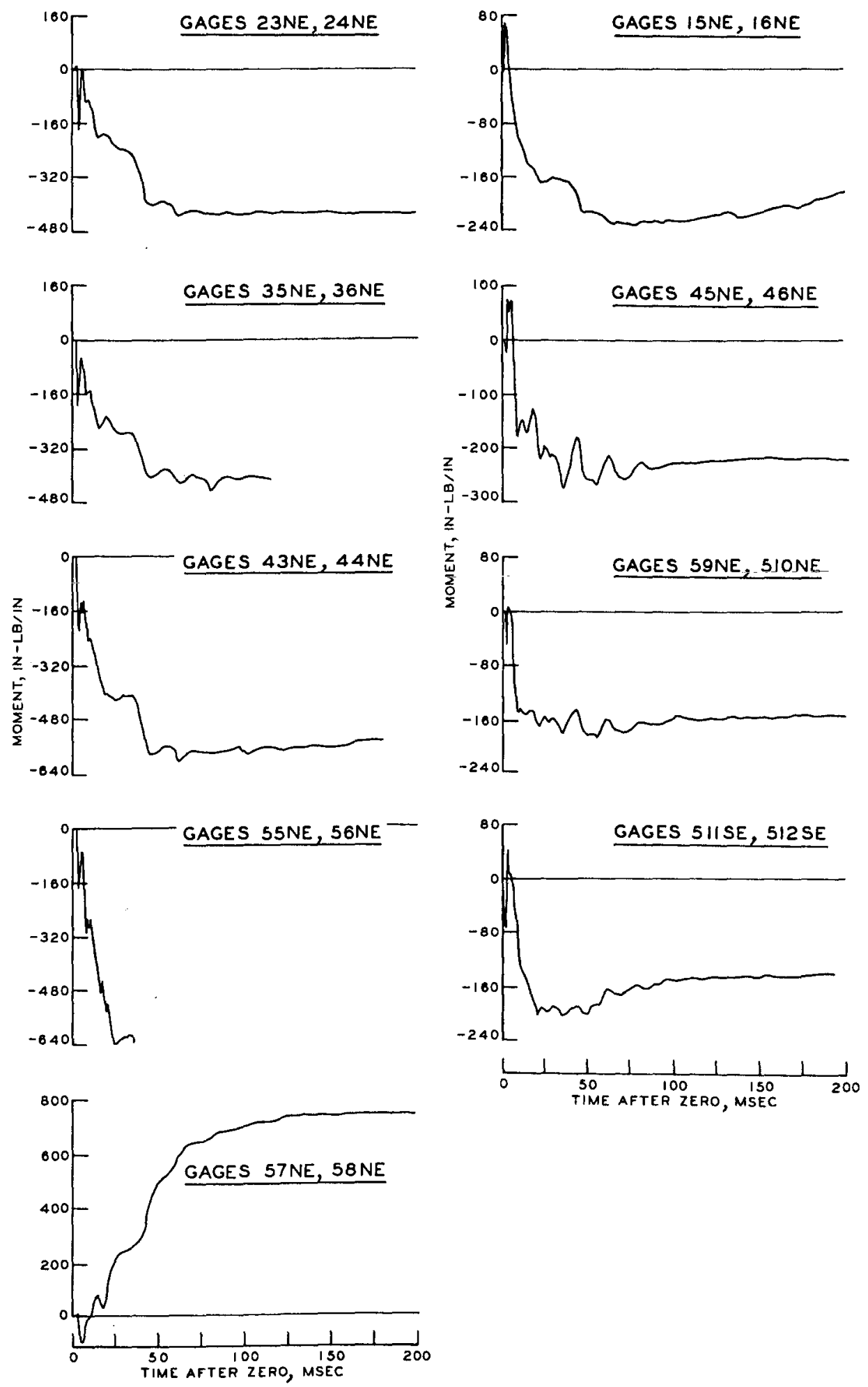

Figure C.16 (Sheet 2 of 2). 

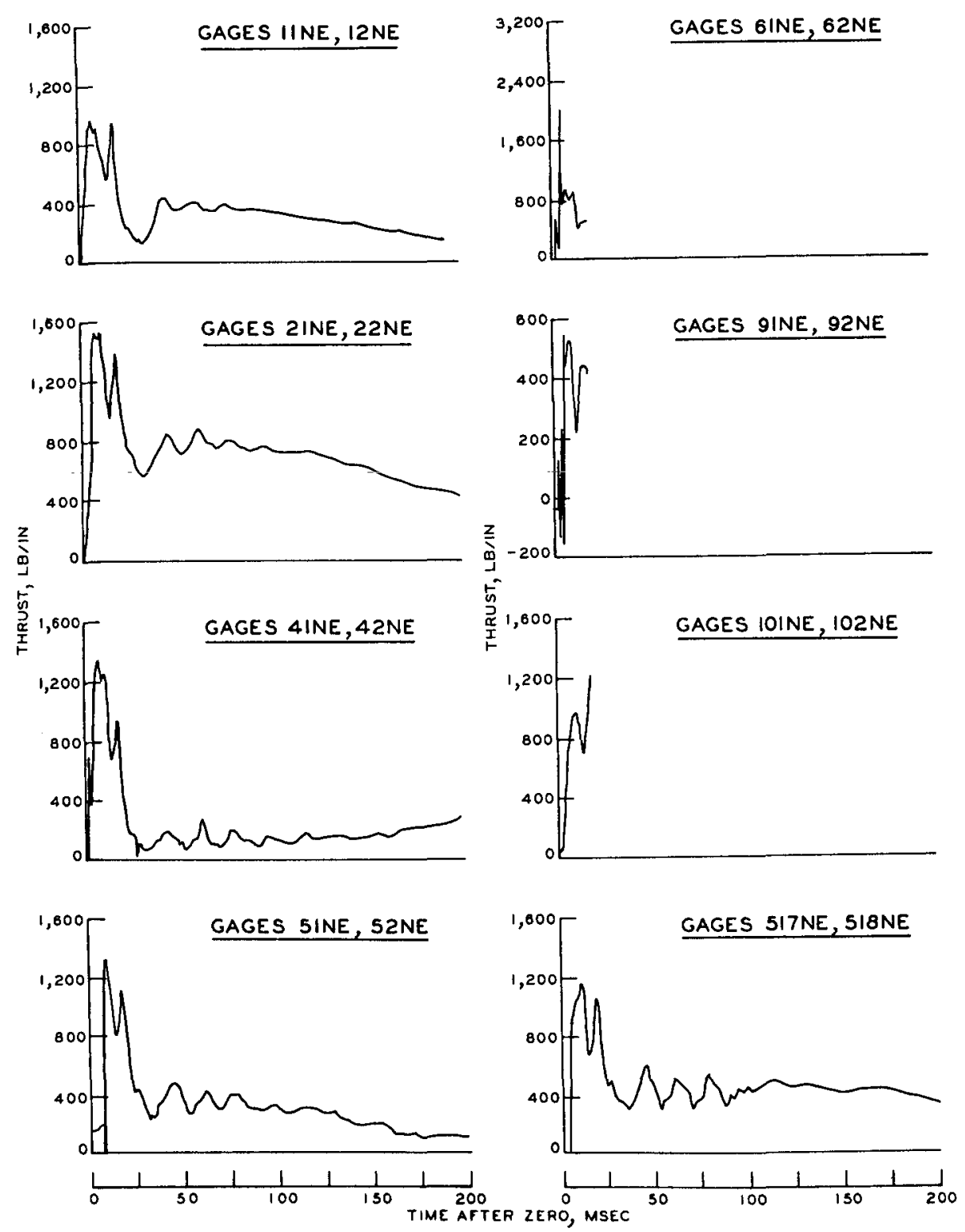

Figure C.17 Thrust data, Shot 4 (Sheet 1 of 2). 

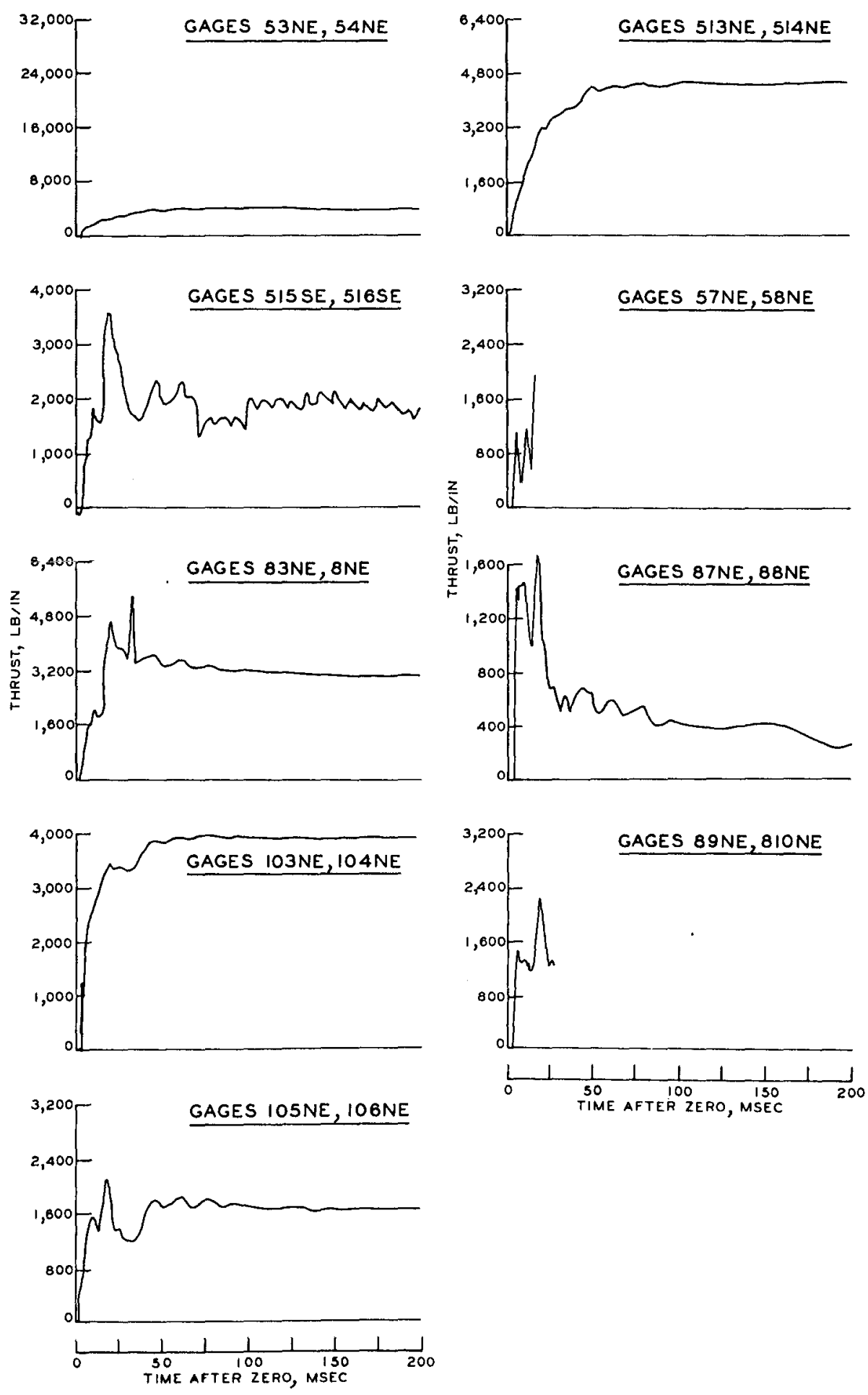

Figure C.17 (Sheet 2 of 2 ). 

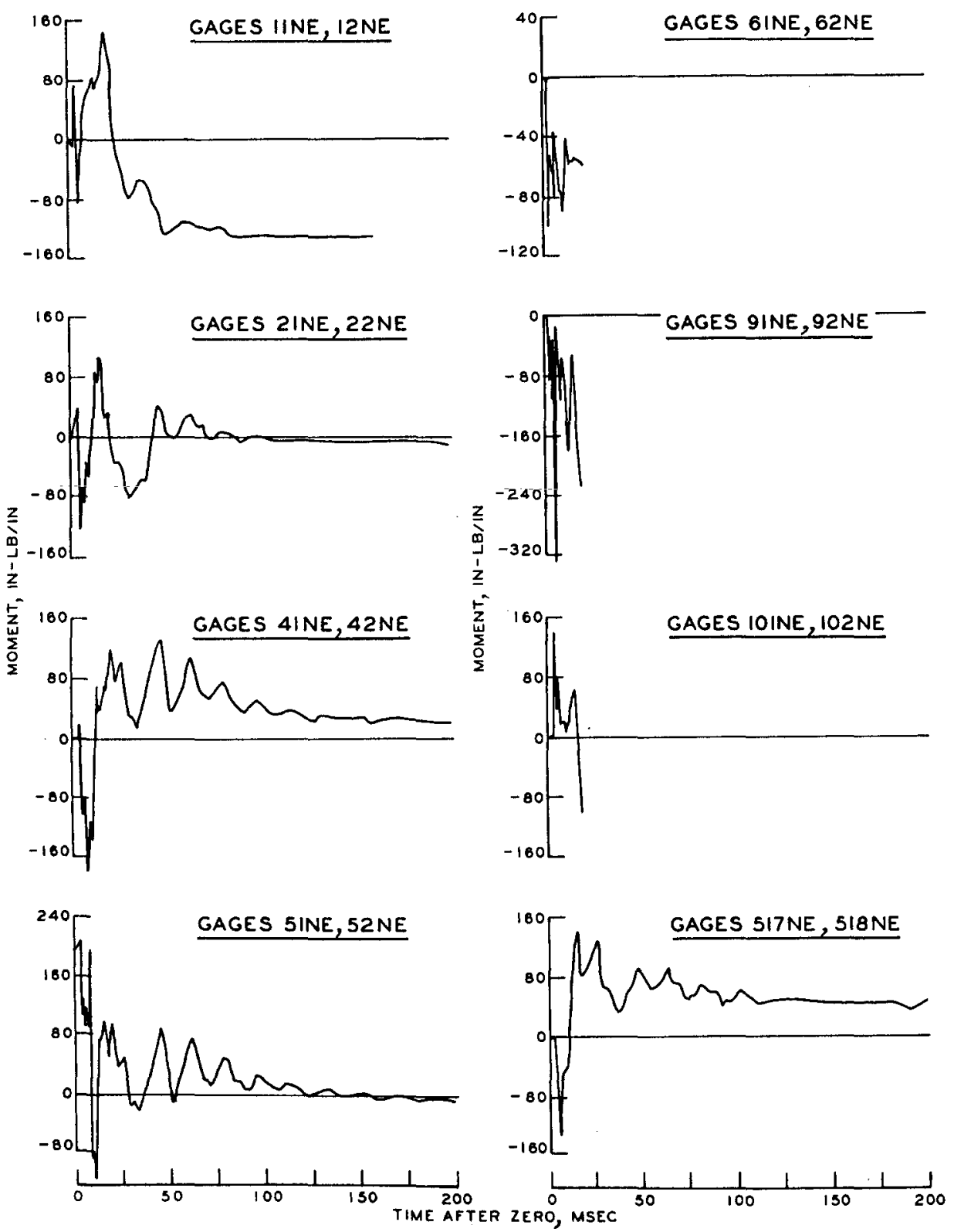

Figure C.18 Moment data, Shot 4 (Sheet 1 of 2). 

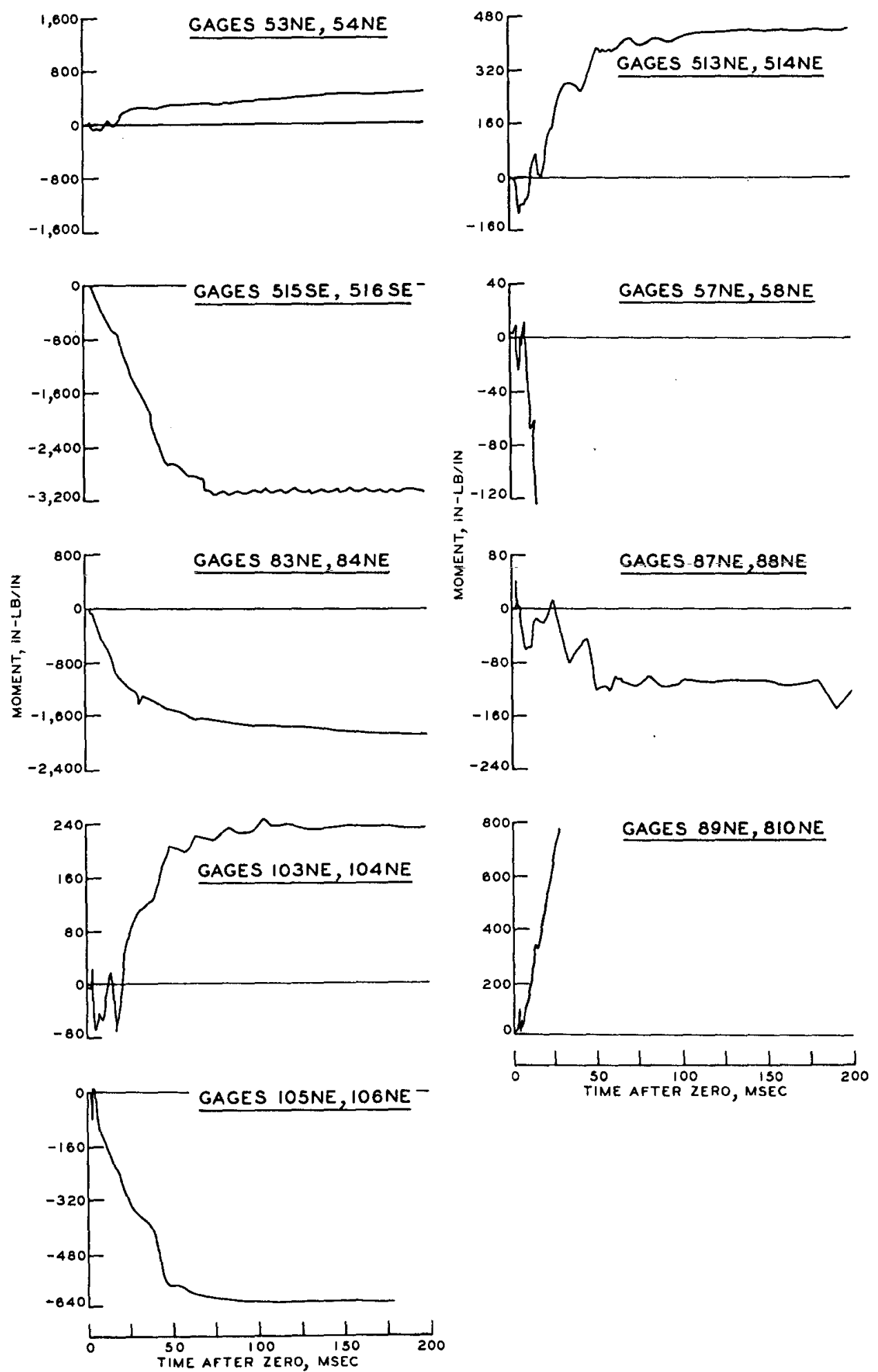

Figure C.18 (Sheet 2 of 2 ). 


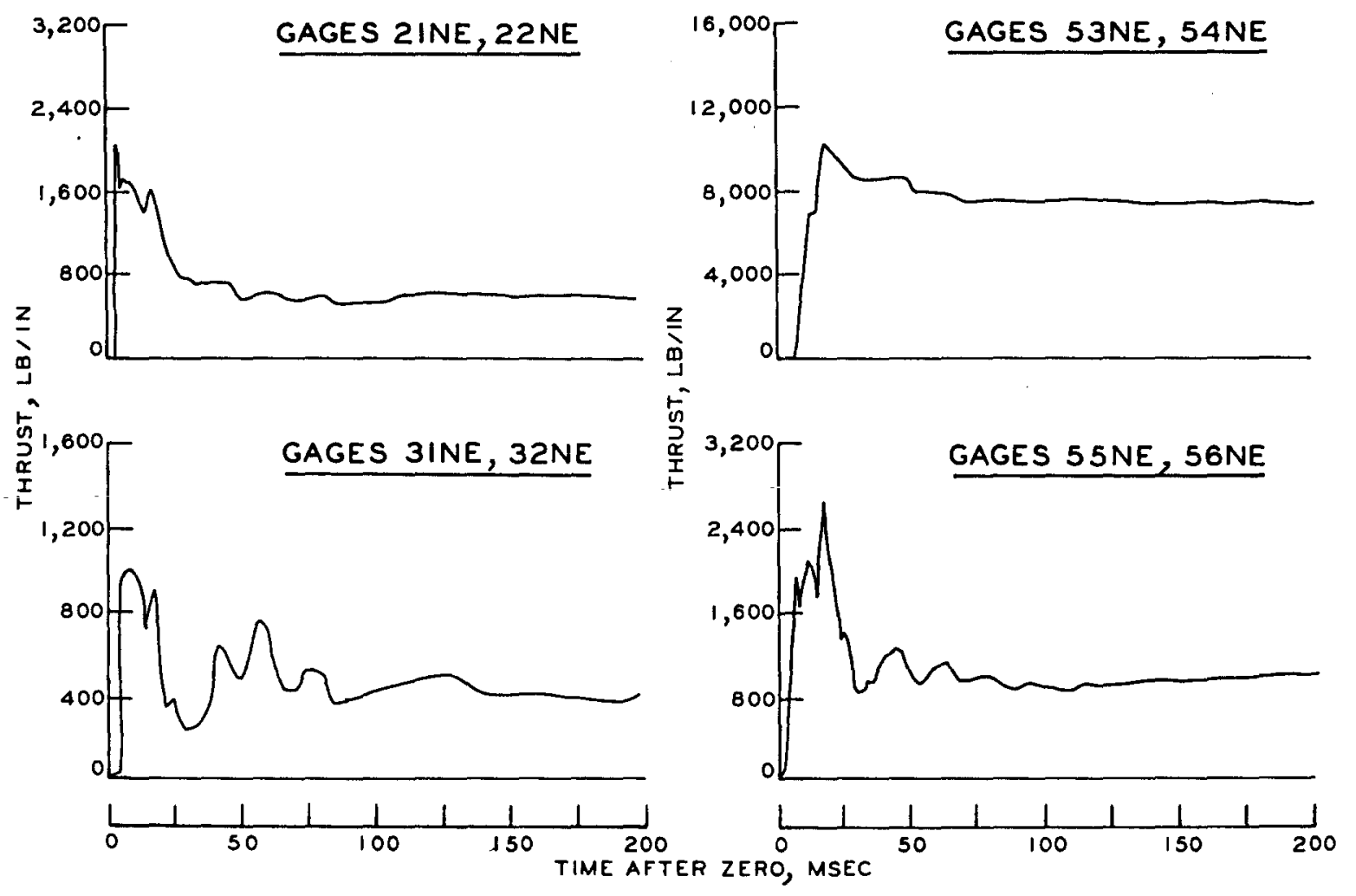

Figure C.19 Thrust data, Shot 5 . 


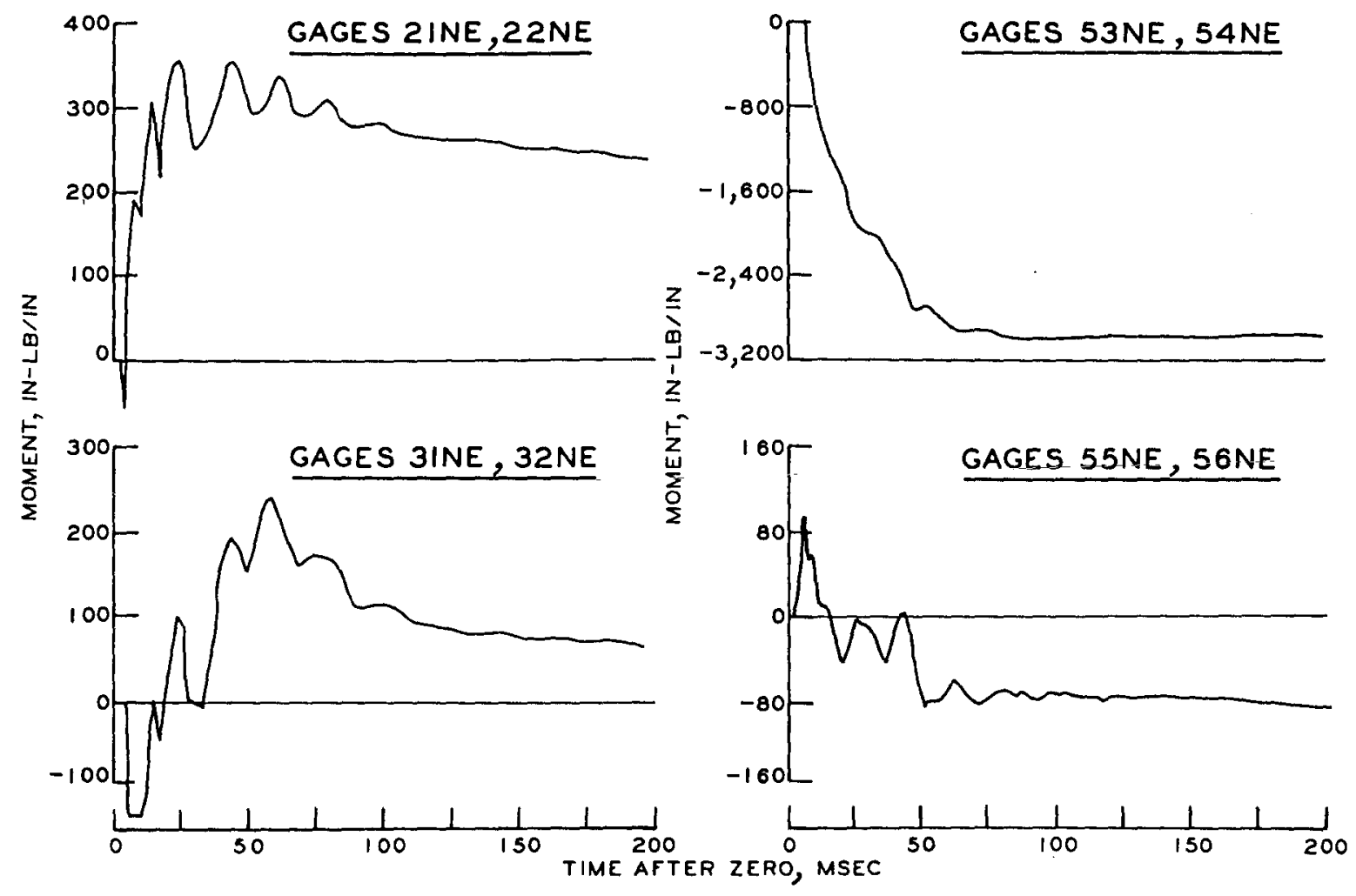

Figure C.20 Moment data, Shot 5 . 

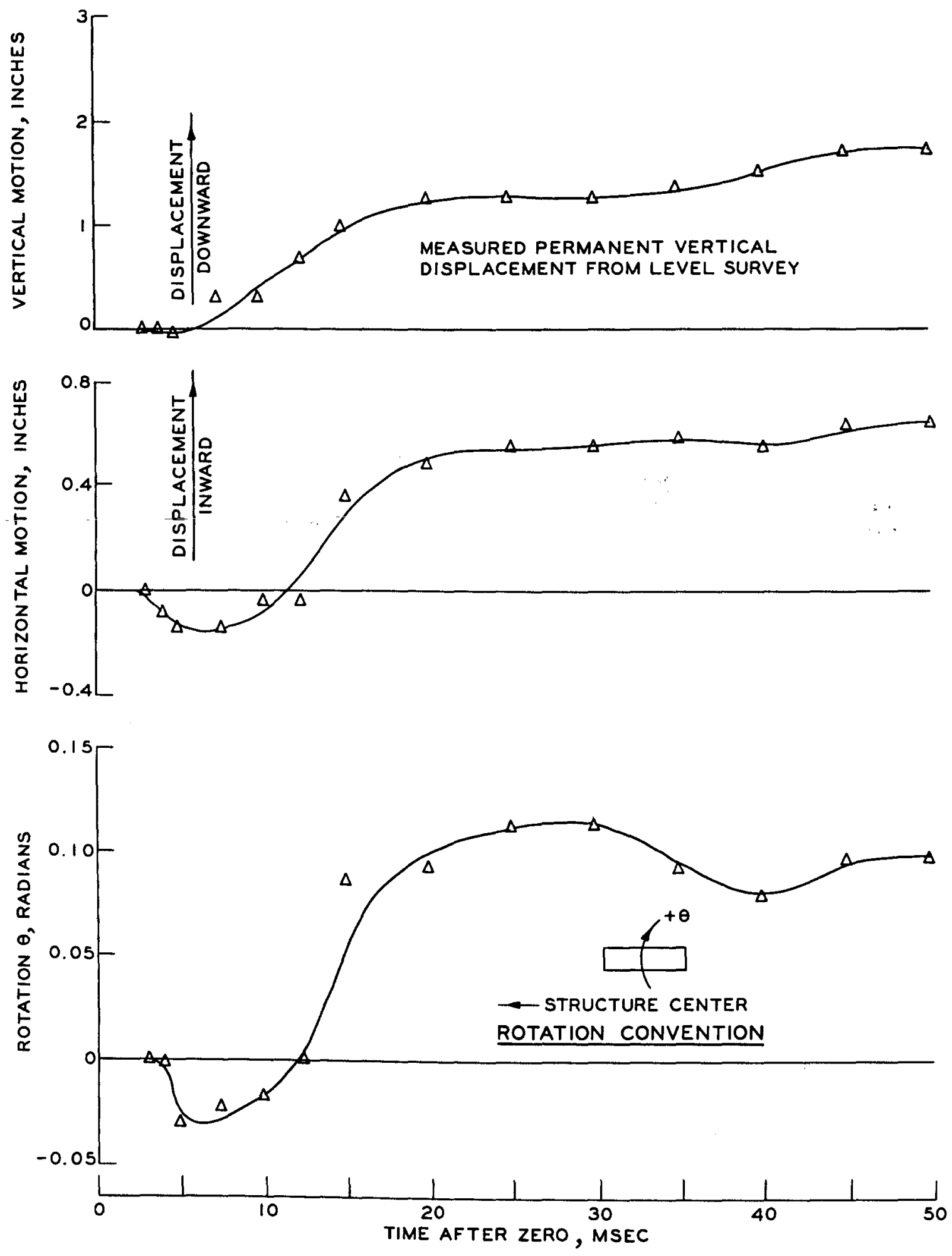

Figure C.21 Footing motion components, Shot 3 . 

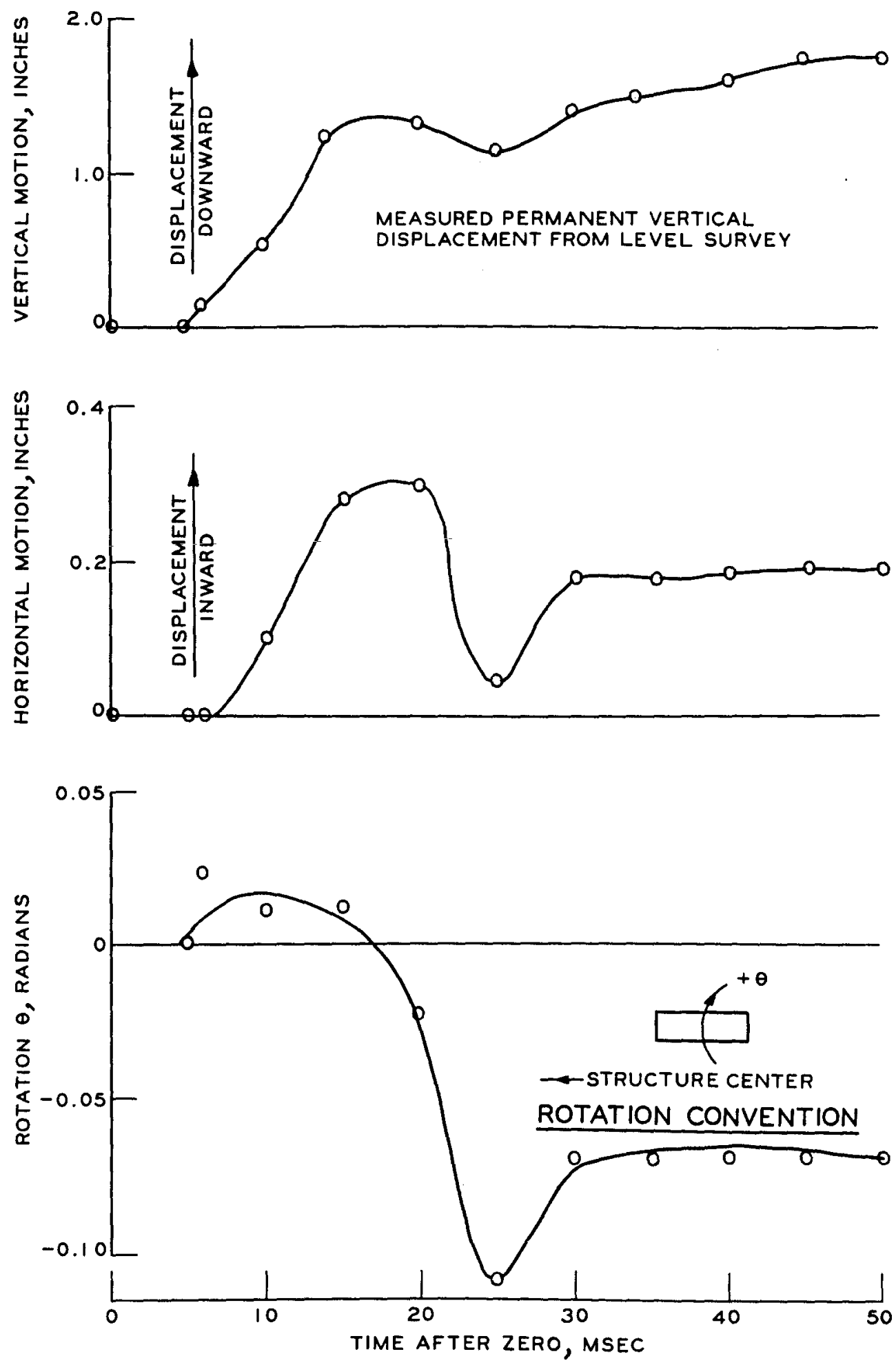

Figure C.22 Footing motion components, Shot 4 . 

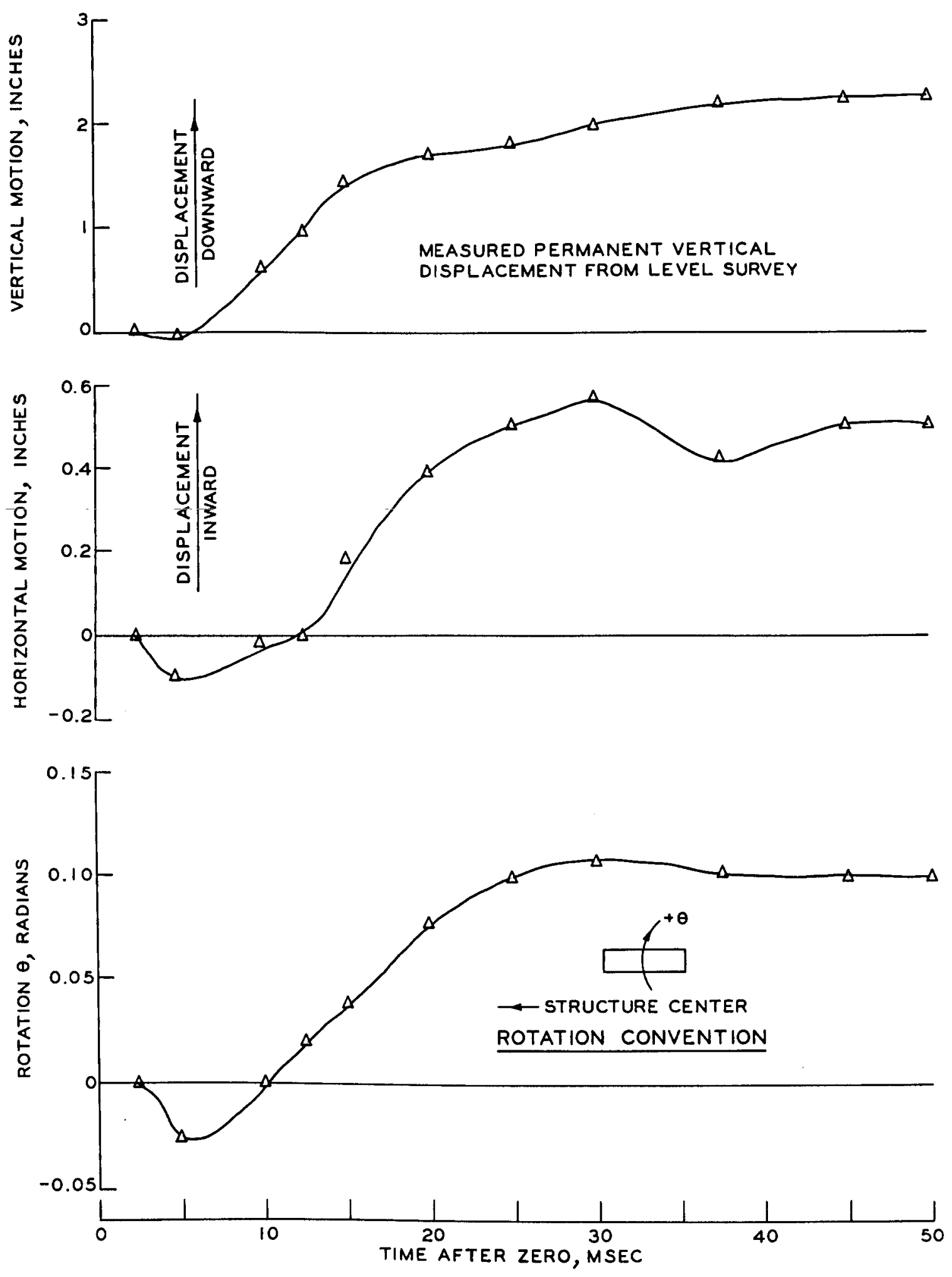

Figure C.23 Footing motion components, Shot 5 . 


\section{APPENDIX D}

BULKHEAD-TRUSS CONNECTOR REDESIGN 
As discussed in Section 3.2.2, difficulties were encountered at the connection between the bulkhead columns and the end truss. These problems arose because of the rotation of the end truss about the connecting bolts which was caused by the gross motion of the structure. To alleviate this problem it was necessary to redesign the connectors to allow for this rotation. This redesign was done between Shots 2 and 3 and was in use during Shot 3. The new connection was designed as a pinned joint. This appendix details the redesign procedures and the redesign, and uses all of the original assumptions made in Reference 1 .

It is assumed that the horizontal loading is 0.5 times the vertical load. Based on this assumption the loads carried by the prototype truss and by the structure truss are as shown in Figure D.I for an overpressure of $150 \mathrm{psi}$ (an overpressure of 150 rather than $100 \mathrm{psi}$ as used in Reference 1 , because indications at the time were that the other component parts of the structure would withstand this higher overpressure). The maximum loads that must therefore be carried by the prototype and the structure connector are 150 and 7.4 kips, respectively. It is further assumed that the ultimate shear strength and the ultimate tensile strength of the steel are $40 \mathrm{kips} / \mathrm{in}^{2}$ and $50 \mathrm{kips} / \mathrm{in}^{2}$, respectively.

The design modification made to the structure is as shown in Figure D.2 and was chosen because of the ease with which the changes could be effected in the existing connectors. Dimensions were chosen as follows. The pin is in double shear and thus

$$
\begin{aligned}
2(40 \mathrm{kips}) \text { Area }= & 7.4 \mathrm{kips} \\
\text { Pin Area }= & 0.093 \mathrm{in}^{2} \\
\text { Pin Diameter Required }= & 0.346 \text { inch or about } \\
& 3 / 8 \text {-inch diameter }
\end{aligned}
$$

For the structure truss the required area is

$$
\begin{aligned}
(50 \mathrm{kips}) \text { Area } & =7.4 \mathrm{kips} \\
\text { Area } & =0.148 \mathrm{in}^{2}
\end{aligned}
$$

Using a 0.25 -inch thickness, the resulting area is $0.155 \mathrm{in}^{2}$, which was 
used. In like manner, the required area of the column is $0.148 \mathrm{in}^{2}$, and by adding another 1/8-inch-thick plate, this area was achieved.

For the prototype, the procedure is the same with the exception that the load is 15 kips. Thus, the pin area is

$$
\begin{aligned}
2(40 \mathrm{kips}) \text { Area } & =150 \mathrm{kips} \\
\text { Pin Area } & =1.88 \mathrm{in}^{2}
\end{aligned}
$$

The nearest standard pin with a conservative area is a 1-3/4-inch pin with an area of $2.41 \mathrm{in}^{2}$. The required truss area is

$$
\begin{aligned}
(50 \mathrm{kips}) \text { Area } & =150 \mathrm{kips} \\
\text { Area } & =3 \mathrm{in}^{2}
\end{aligned}
$$

Prototype truss design calls for 8.2-1b/ft, 6-inch channel to be used as this connector. This means that a reinforcing strip on either side can only be 4.5 inches wide and, thus, the thickness of this plate should be $7 / 16$ inch. This yields an area of $3.2 \mathrm{in}^{2}$. These plates are to extend 5 inches past the outer edge of the truss as shown in Figure D.3. Column modifications are made as shown in Figures D. 4 and D.5. Using the 3/8inch plate as shown and assuming that the resisting area extends above the pin a distance equal to the length below, then the resisting area is 3.2 in $^{2}$, which is sufficient. 


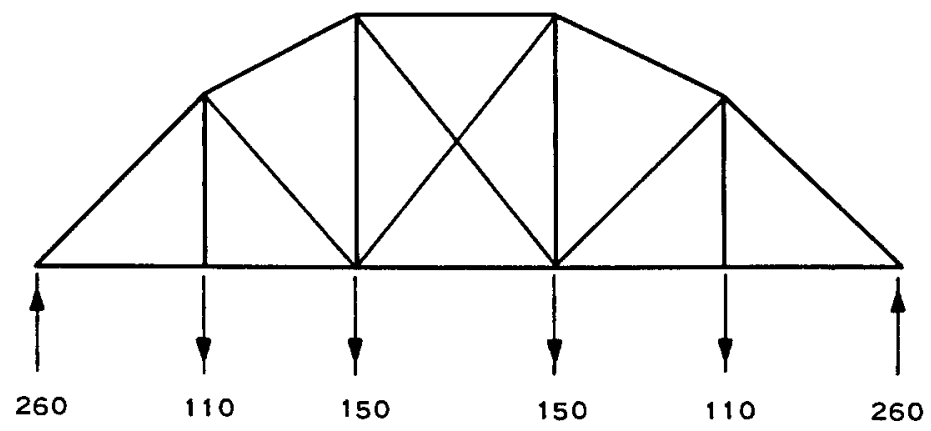

PROTOTYPE TRUSS LOADING

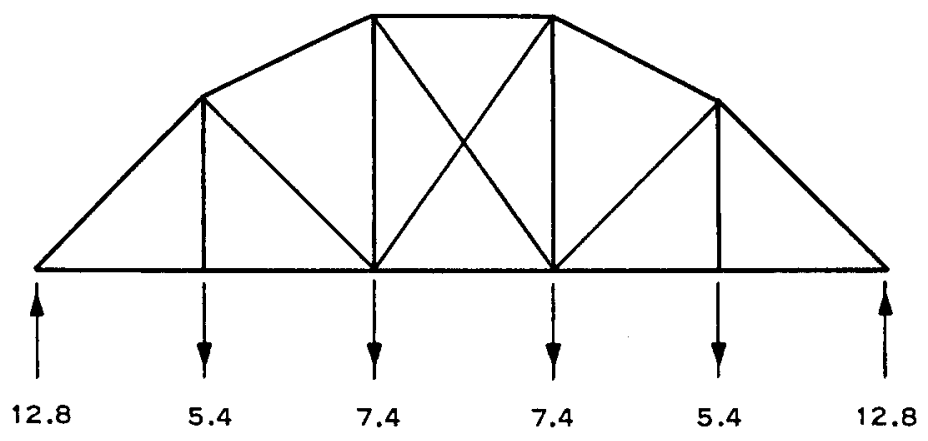

MODEL TRUSS LOADING

Figure D.I Assumed loading on the prototype and on the model truss. Loads are in kips. 


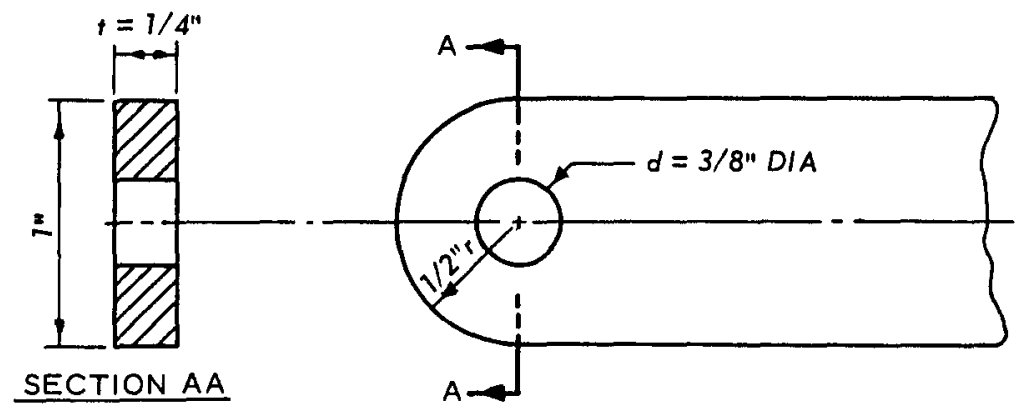

a. TRUSS MODIFICATION
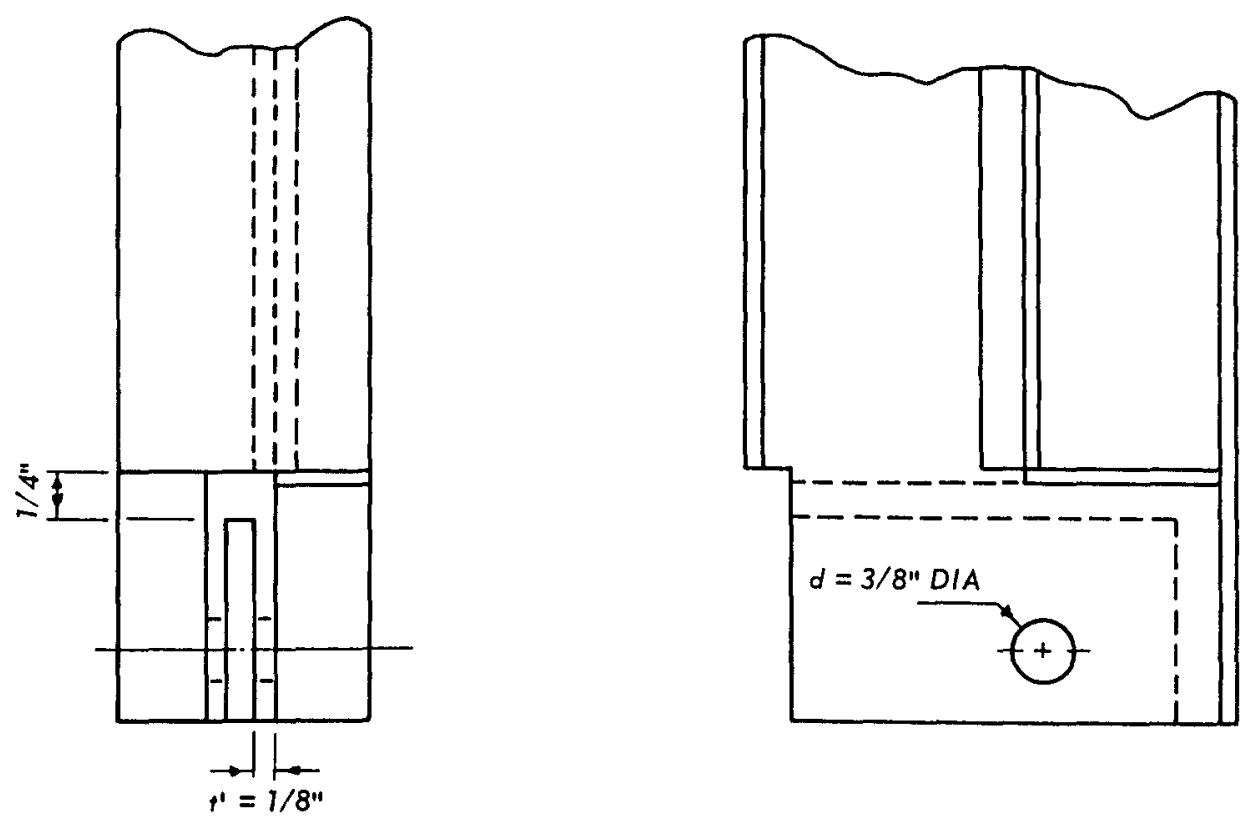

b. COLUMN MODIFICATION

Figure D.2 Detail of the modifications made to the structure column-truss connection. 


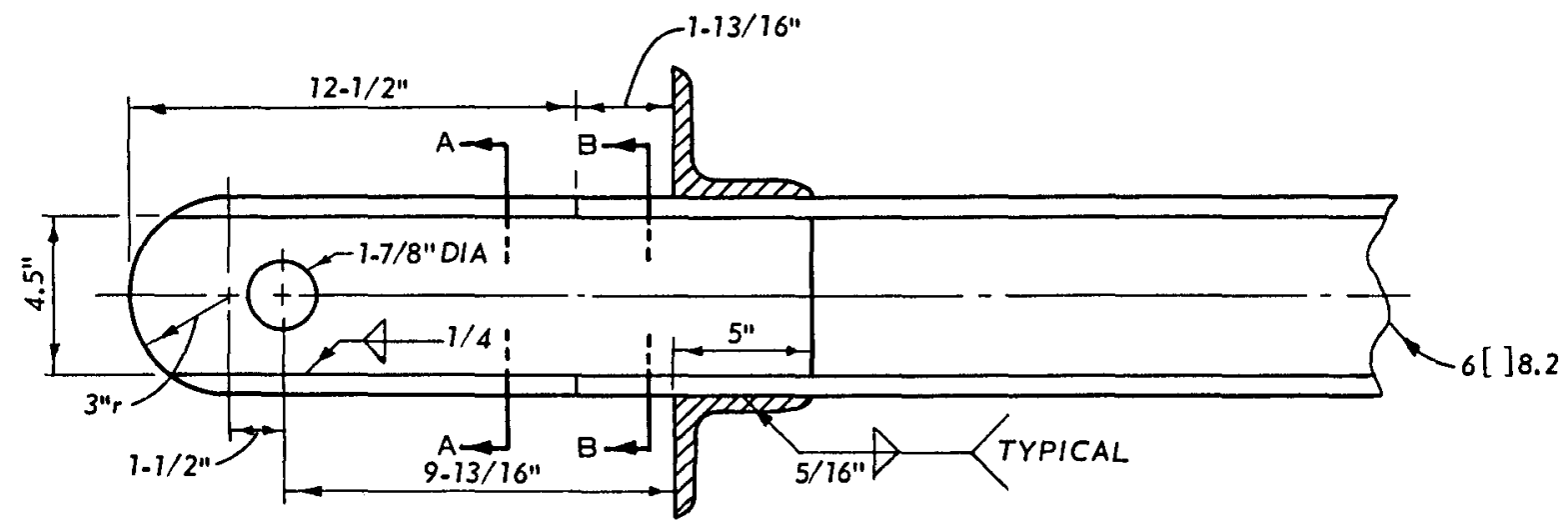

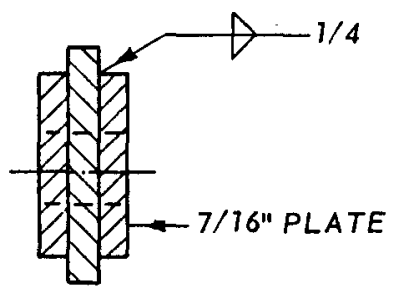

SECTION AA

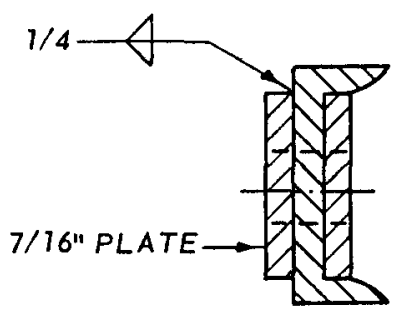

SECTION BB

Figure D.3 Detail of the modifications made in the prototype truss connector design. 

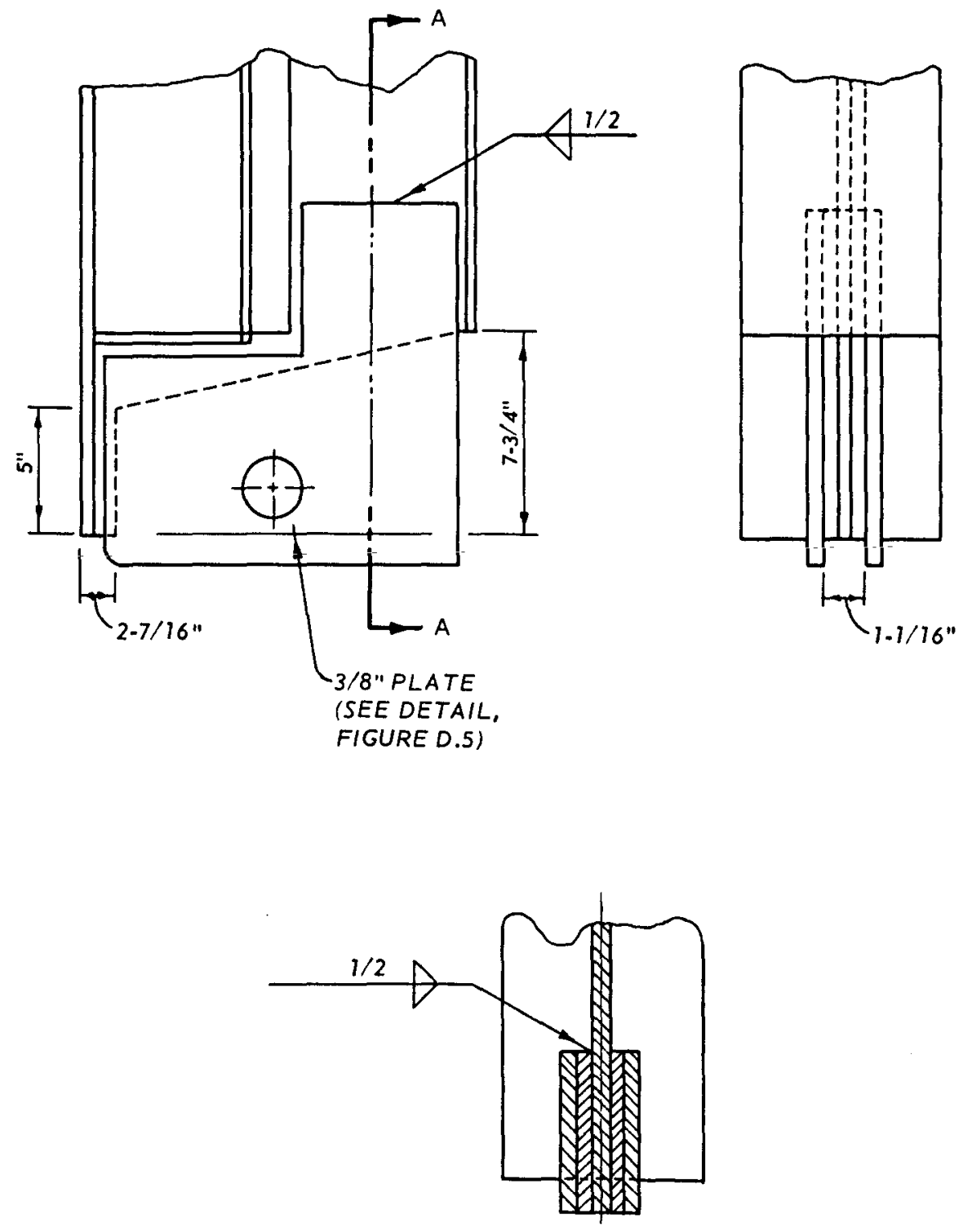

SECTION AA

Figure D.4 Detail of the modifications made in the prototype column connector design. 

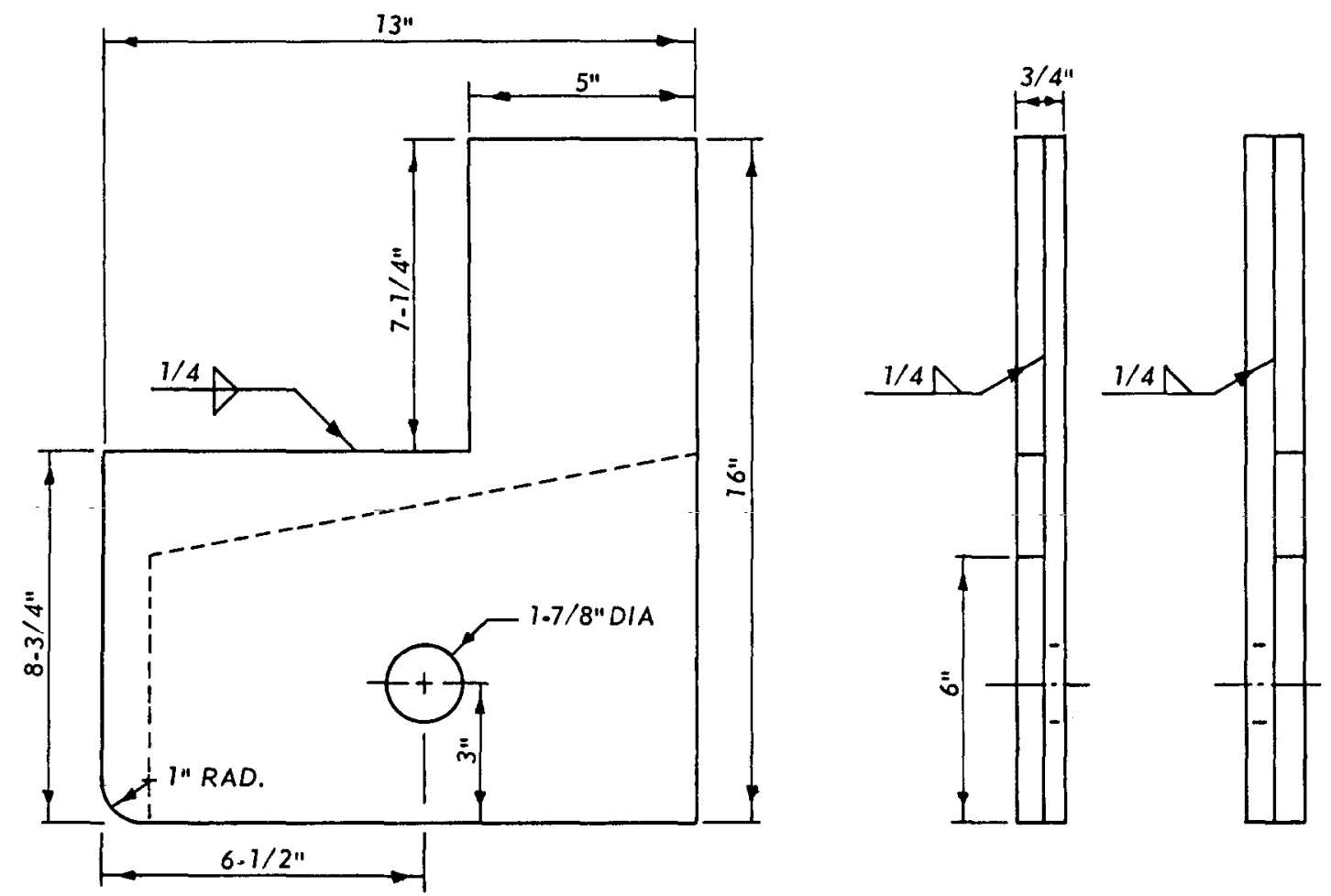

NOTE: SPACERS WELDED ON NEAR SIDE AND ON FAR SIDE. A LEFT-HANDED PLATE AND A RIGHT-HANDED PLATE REQUIRED FOR EACH COLUMN. WELD FROM $3 / 8$ INCH PLATE.

Figure D.5 Plate detail for prototype column connector modification. 
1. N. M. Newmark, J. W. Briscoe, and J. L. Merritt; "Analysis and Design of Flexible Underground Structures"; Contract Report No. 2-4I, Final Report, Phase I, October 1962; U. S. Army Engineer Waterways Experiment Station, CE, Vicksburg, Mississippi; Report prepared under Contract DA-22o79-eng-225; Unclassified.

2. N. M. Newmark and Associates; "Design of Model Test Program for a Buried Field Shelter"; Contract Report No. 1-110, Phase III, May 1965; U. S. Army Engineer Waterways Experiment Station, CE, Vicksburg, Mississippi; Report prepared under Contract DA-22-079-eng-225; Unclassified.

3. T. E. Kennedy and J. T. Ballard; "Dynamic Test of a Model FlexibleArch-Type Protective Shelter; Pilot Test"; Technical Report No. 1-768, Report 1, April 1967; U. S. Army Engineer Waterways Experiment Station, CE, Vicksburg, Mississippi; Unclassified.

4. G. E. Albritton; "Description, Proof Test, and Evaluation of Blast Load Generator Facility"; Technical Report No. 1-707, December 1965; U. S. Army Engineer Waterways Experiment Station, CE, Vicksburg, Mississippi; Unclassified.

5. T. E. Kennedy, G. E. Albritton, and R. E. Walker; "Initial Evaluation of the Free-Field Response of the Large Blast Load Generator" ; Technical Report No. 1-723, June 1966; U. S. Army Engineer Waterways Experiment Station, CE, Vicksburg, Mississippi; Unclassified.

6. R. V. Whitman, Z. Getzler, and K. Hoeg; "Tests Upon Thin Domes Buried in Sand"; Professional Paper P62-15, December 19́62; Massachusetts Institute of Technology, Cambridge, Massachusetts; Unclassified.

7. W. L. Durbin; "Study of the Dynamic Stress-Strain and WavePropagation Characteristics of Soils; Measurements of Stress-Strain Peak Particle Velocity, and Wave-Propagation in Three Sands"; Contract Report No. 3-91, Report 3, February 1965; U. S. Army Engineer Waterways Experiment Station, CE, Vicksburg, Mississippi; Report prepared under Contract No. DA-22-079-eng-373; Unclassified.

8. J. K. Ingram; "The Development of a Free-Field Soil Stress Gage for Static and Dynamic Measurements"; 1965; Instruments and Apparatus for Soil and Rock Mechanics, ASTM STP 392, American Society for Testing and Materials, Philadelphia, Pennsylvania; Unclassified.

9. A. C. Whiffin and S. A. H. Morris; "Piezoelectric Gauge for Measuring Dynamic Stresses Under Roads"; The Engineer, April 1962, Vol. 213, No. 5544, Pages 741-746; Iondon, England; Unclassified. 


\section{Army}

Assistant Chief of Staff for Force Development, Department of the

Army, Washington, D. C. 20310

ATTN: FOR DS SSS

Chief of Research and Development, Department of the Army,

Washington, D. C. 20310

ATTN : CRDCM

CRDES

1

CRDISO

Chief of Engineers, Department of the Army, Washington, D. C. 20315

ATTN: ENGME-RD

ENGMC-ER

ENGAS-T

ENGME-S (21000)

Commanding General, U. S. Army Materiel Command, Washington, D. C. 20315

ATTN : AMCRD-TV

AMCRD-GME

AMCRI,

Commanding General, U. S. Continental Army Command, Fort Monroe,

Va. 23351

ATTN: Engineer Division

Commanding General, U. S. Army Weapons Command, Rock Island, Ill.

61201

ATTN : AMSWE-REE-D

Commanding General, U. S. Army Test and Evaluation Command,

Aberdeen Proving Ground, Md. 21005

ATTN: Tech Library

Commanding General, United States Training Center, Fort Leonard

Wood, Mo. 65473

Commanding Officer, U. S. Army Combat Developments Command Engineer Agency, Fort Belvoir, Va. 22060

ATTN : CSGEN-M 


\section{Army (Continued)}

Commanding officer, Yuma Proving Ground, Yuma, Ariz. 85364

ATTN : STEYP-COA

STEYT-TAT

Technical Library

Commanding Officer, USA Mobility Equipment Research and

Development Center, Fort Belvoir, Va. 22060

ATTN: SMEFB-RDE-KC

SMEFB-RDE-MW

SMEFB-FI

Commandant, USA Command and General Staff College, Fort Levenworth, Kans. 66027

ATTN: Engineer

Archives

Director, U. S. Army Cold Regions Research Engineering Laboratory, 2 Hanover, N. H. 03755

Director, U. S. Army Constmuction Engineering Research Laboratory, P. 0. Box 4005, Champaign, IIl. 61820

Director, Nuclear Cratering Group, U. S. Army Corps of Engineers, Lawrence Radiation Laboratory, P. 0. Box 808, Livermore, Calif. 94551

Director, U. S. Army Land War Laboratory, Aberdeen Proving Ground, Md. 21005

ATTN : Chief, Applied Research Division

Technical Library Branch No. 4

Commandant, Fort Belvoir, Va. 22060

ATTN: The Librarian, Thayer Hall

Dept of Engineering, Field Engineering Branch

Dept of Engineering, Heavy Construction Branch

Dept of Engineering, General Engineering Branch

2

1

Dept of Doctrine Review and Literature, Training Literature 3

Division

U. S. Army Continental Army Command Intelligence Center, Fort

Bragg, N. C. 28307

ATTN: Library, IPO

Senior Engineer Instructor, Office of Military Instruction, United 1

States Corps of Cadets, West Point, N. Y. 10996

Commandant, U. S. Army Air Defense School, Fort Bliss, Tex. 799161

ATTN : Engineer Officer

Commandant, U. S. Army Armor School, Fort Knox, Ky. 40121 


\section{Army (Continued)}

Commandant, U. S. Army Artillery and Missile School, Fort Sill,

Okla. 73503

ATTN: Engineer Officer

Commandant, U. S. Army Aviation School, Fort Rucker, Ala. 36360

ATTN: Engineer Officer

Commandant, U. S. Army Infantry School, Fort Benning, Ga. 31905

ATTN: Engineer Officer

Commandant, U. S. Army Intelligence School, Fort Holabird, Md. 21219

ATTN : Engineer Officer

Commandant, U. S. Army Missile and Munitions Center and School, Redstone Arsenal, Ala. 35809

ATTN: Engineer Officer

Commanding General, U. S. Army Ordnance Center and School,

Aberdeen Proving Ground, Md. 21005

ATTN : Engineer Officer

Commandant, U. S. Army Special Warfare School, Fort Bragg, N. C. 28307

ATTN: Engineer Officer

Division Engineer, U. S. Army Engineer Divisions, Continental United States

Director of Civil Defense, Office of the secretary of the Army, ea

Washington, D. C. 20310

ATTN: Mr. George Sisson (RE-ED)

Commanding Officer, U. S. Army Combat Developments Command,

Institute of Nuclear Studies, Fort Bliss, Tex. 79916

Commanding General, U. S. Army Combat Developments Command,

Institute of Land Combat, 2461 Eisenhower Ave., Alexandria, Va. 22314

ATTN : CDILC-MST

Commanding General, Aberdeen Proving Ground, Aberdeen, Md. 21005

ATTN: Director, Ballistic Research Laboratories

Commanding General, USA Missile Command, Funtsville, Ala. 35809

Commanding General, USA Munition Command, Dover, N. J. 07801

Commandant, Army War College, Carlisle Barracks, Pa. 17013

ATTN : Library

Superintendent, U. S. Military Academy, West Point, N. Y. 10996 
ATTN : CDCAVNA

Commandant, U. S. Army Engineer School, Fort Belvoir, Va. 22060

Commander-in-Chief, U. S. Army, Europe, APO New York 09403

ATTN: The Engineer

Commanding Officer, U. S. Army Combat Development Command, Fort Belvoir, Va. 22060

ATTN : CDCMR-O

CDCCSG

CDCEA

Commanding Officer, U. S. Army Combat Development Command, Fort Leavenworth, Kans. 66027

ATTN : CDCCAG

$\underline{\text { Navy }}$

Commanding Officer and Director, Naval Civil Engineering

Laboratory, Port Hueneme, Calif. 93041

Commander, Naval Facilities Engineering Command, Navy Department, Washington, D. C. 20390

ATTN : NFAC-03

NFAC-O4

Chief, Combat Service Support Division, Marine Corps Landing Force I Development Center, Marine Corps Schools, Quantico, Va. 22134

Commander-in-Chief, U. S. Atlantic Fleet, U. S. Naval Base, Norfolk, Va. 2351I

Commandant of the Marine Corps, Navy Department, Washington, D. C. 4 20380

ATTN : Code AOLE

Commanding General, USMC Development and Education Command,

Quantico, Va. 22134

Commanding Officer, Nuclear Weapons Training Center, Atlantic I Naval Base, Norfolk, Va. 23511

ATTN: Nuclear Warfare Department

Officer-in-Charge, U. S. Naval Civil Engineer Corps Officer School, I U. S. Naval Construction Battalion Center, Port Hueneme, Calif. 93041

Commanding Officer, U. S. Naval Construction Battalion Center, Gulfport, Miss. 39502 


\section{Navy (Continued)}

Commander, U. S. Naval Ordnance Test Station, China Lake, Calif. 93555

\section{Air Force}

Director of Civil Engineering, Headquarters, USAF, Washington,

D. C. 20310

ATTN : APOCE-KA

APOCE-GC

Commanding General, Tactical Air Command, USAF, Langley AFB,

Va. 23365

ATTN : DEPL

Director of Civil Engineering, Headquarters, Strategic Air

Command, Offutt AFB, Nebr. 68113

DCS/Research and Development, Headquarters, USAF, Washington,

D. C. 20330

ATTN: (AFRSTC) Astronautics Division

Director of Civil Engineering (SCOC), Headquarters, Air Force

Systems Command, Andrews AFB, Washington, D. C. 20331

Commander, U. S. Strike Command, MacDill AFB, Fla. 33608

ATTN : Engineer, J4

Chief, Concepts and Evaluation Group

Commander, Headquarters, Military Airlift Command, Scott AFB,

I11. 62225

ATTN : MAMCE/FS

Commander, Air Force Systems Command, Aeronautical Systems

Division, Wright-Patterson AF'B, Ohio 45433

ATTN : ASJT

ASNMS-200

Commander, Advanced Development Tactical Command, Eglin AF'B,

Fla. 32542

ATIN : ADBPS-12

Commander, Air Proving Ground Command, Eglin AFB, Fla. 32542

ATIN : PGBPS-12

Commander, 3800th $A B$ Wing, Maxwell AFB, Ala. 36112

ATTN: Base Civil Engineering BEE, Bldg 18

Chief, Civil Engineering Branch, Air Force Weapons Laboratory, Kirtland AFB, N. Mex. 87117 


\section{Other DOD Agencies}

Director, Defense Atomic Support Agency, Washington, D. C. $20301 \quad I$ ATTN : SPSS

Director of Defense Research and Engineering, Washington, D. C. 20301

ATTN : Technical Library

Mr. Frank J. Thomas

Commandant, National War College, Washington, D. C. 20310

ATTN: Class Rec. Library

President, U. S. Army Infantry Board, Fort Benning, Ga. 31905

Commanding Officer, U. S. Army Materials and Mechanical Research

Center, Watertown, Mass. 02172

Director, Defense Communications Planning Group, Bldg 56, U. S. Naval Observatory, Washington, D. C. 20305

Director, Defense Intelligence Agency, Department of Defense, Washington, D. C. 20301

ATTN : DIAAP-IOAI

DIAAP-IE2

Defense Documentation Center, Cameron Station, Alexandria, Va. 22313

ATTN: Mr. Myer Kahn

\section{Other}

U. S. Government Printing Office, Division of Public Documents,

Washington, D. C. 20401

ATTN: Library

Library of Congress, Documents Expediting Project, Washington, D. C. 20540

Research Analysis Corporation, McLean, Va. 22101

ATTN : Library

WIRE, Inc., Chestertown, Md. 21620

ATTN: Library

Battelle Memorial Institute, Columbus, Ohio 43201

ATTN : RACIC

Engineering Societies Library, 345 East 47 th Street, New York, N. Y. 10017 


\section{Other (Continued)}

Stanford Research Institute, Menlo Park, Calif. 94025

ATTN: Mr. Gordon S. Wiley

Director, Naval War Research Center

Library

1

Massachusetts Institute of Technology, Cambridge, Mass. 02139

ATTN: Soil Engineering Library 
DOCUMENT CONTROL DATA - R \& D

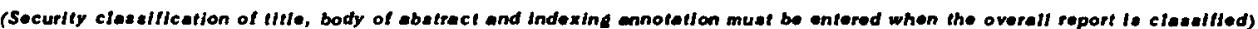
1. ORIGINATINC ACTIVITY (Corporate author)

U. S. Army Engineer Waterways Experiment Station

Vicksburg, Mississippi

24. REPORT SECUAITY CLASEIFICATION Unclassified

3. REPONT TITLE

DYNAMIC TESTS OF A MODEI FIEXIBIE-ARCH-TYPE PROTECTIVE SHELTER

4. DEscrup TIVE NOTEs (Type of report and inclualve datas)

Final report

5. AU THOR(S) (Firel nome, middlo Inithal, Taei namo)

Thomas E. Kennedy

\begin{tabular}{|c|c|c|}
\hline $\begin{array}{l}\text { 6. AEPORT OATE } \\
\text { April } 1971\end{array}$ & $\begin{array}{c}\text { 70. TOTAL NO. OF PAGES } \\
173\end{array}$ & $\begin{array}{c}\text { 7b. NO. OF AEFs } \\
9\end{array}$ \\
\hline W. CONTRACT OR GRANT NO. & \multicolumn{2}{|c|}{ QE. ORIGINA TON'S REPORT NUMTERR(S) } \\
\hline D. PROJECT no. 4A022601A880-03 & \multicolumn{2}{|c|}{ Miscellaneous Paper $N=71-3$} \\
\hline c. & \multicolumn{2}{|c|}{$\begin{array}{l}\text { 96. ORHER MEPORT NO(S) (Any Other numbord thet may be aeolened } \\
\text { thid moport) }\end{array}$} \\
\hline d. & & \\
\hline
\end{tabular}

10. DISTRIDUTION ETATEMENT

Approved for public release; distribution unlimited

\begin{tabular}{l|l}
\hline 11. SUPRL EMENTARY NOTE: & $\begin{array}{l}\text { 12. SPONSORING MILITARY ACTIVITY } \\
\text { Office, Chief of Engineers, U. S. Army } \\
\text { Washington, D. C. }\end{array}$
\end{tabular}

10. ADSTAACT

The general objective of this study was to determine the dymamic response of a buried model flexible-arch troop shelter to simulated nuclear blast overpressures. To accomplish this, a model structure was constmucted using a geometric scaling ratio of 1 to 4.5. The structure was buried in dense, dry sand with the depth of cover over the crown equal to one-fourth of the arch diameter and tested in the Waterways Experiment Station large Blast Load Generator. A series of five tests was conducted at overpressures ranging from 37 to $177 \mathrm{psi}$ with the model being excavated and rebuilt after each test. Strain, acceleration, and deflection were measured at various points on the structure; measurements were also made of the pressure inside the structure, stress and acceleration in the free field, and overpressure at the soil surface. Visible damage consisted of arch deformation, footing deflection, and fracture of the end truss bulkhead connector at the higher overpressures. All transient measurements in general were recorded successfully. The results of this study show that the model structure as designed can withstand almost twice the design overpressure of 100 psi for large duration times ( 100 to $200 \mathrm{msec}$ ). Redesign of the truss connector can be accomplished as detailed in Appendix D so that no fracture occurs in this area. The instrumentation employed is described in detail in Appendix A. Raw and computed data are contained in Appendixes B and C, respectively. 
Unclassified

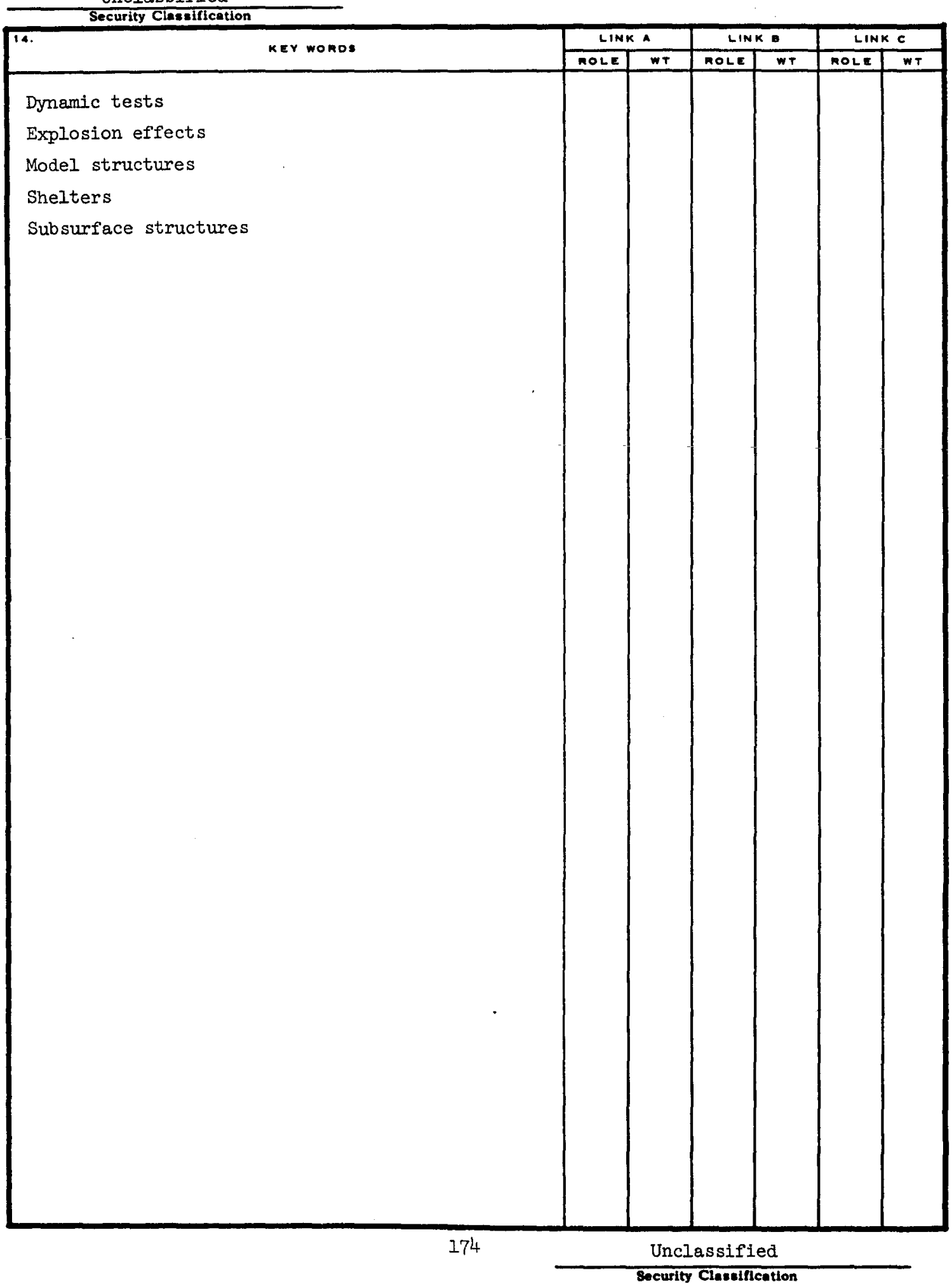

